Elisa Platzeck Leonardi

\title{
As questões de direito e os estados de causa no livro 3 da Institutio Oratoria de Quintiliano
}

\section{(VERSÃO CORRIGIDA)}

Tese apresentada ao Programa de Letras Clássicas do Departamento de Letras Clássicas e Vernáculas da Faculdade de Filosofia, Letras e Ciências Humanas da Universidade de São Paulo, para obtenção do título de Doutor em Letras Clássicas.

Orientador: Prof. Dr. Adriano Scatolin

São Paulo 
UNIVERSIDADE DE SÃO PAULO

FACULDADE DE FILOSOFIA, LETRAS E CIÊNCIAS HUMANAS DEPARTAMENTO DE LETRAS CLÁSSICAS E VERNÁCULAS PROGRAMA DE PÓS-GRADUAÇÃO EM LETRAS CLÁSSICAS

\title{
As questões de direito e os estados de causa no livro 3 da
}

\author{
Institutio Oratoria de Quintiliano
}

\section{(VERSÃO CORRIGIDA)}

Elisa Platzeck Leonardi

Tese apresentada ao Programa de Letras Clássicas do Departamento de Letras Clássicas e Vernáculas da Faculdade de Filosofia, Letras e Ciências Humanas da Universidade de São Paulo, para obtenção do título de Doutor em Letras Clássicas.

Orientador: Prof. Dr. Adriano Scatolin

São Paulo 
Autorizo a reprodução e divulgação total ou parcial deste trabalho, por qualquer meio convencional ou eletrônico, para fins de estudo e pesquisa, desde que citada a fonte.

Catalogação na Publicação

Serviço de Biblioteca e Documentação

Faculdade de Filosofia, Letras e Ciências Humanas da Universidade de São Paulo

Leonardi, Elisa

L581q As questões de direito e os estados de causa no livro 3 da Instituto oratória de Quintiliano / Elisa Leonardi ; orientador Adriano Scatolin. - São Paulo, 2019.

$300 \mathrm{f}$.

Tese (Doutorado)- Faculdade de Filosofia, Letras e Ciências Humanas da Universidade de São Paulo. Departamento de Letras Clássicas e Vernáculas. Área de concentração: Letras Clássicas.

1. Retórica Latina CR792.3.2.2. I. Scatolin, Adriano, orient. II. Título. 


\title{
ENTREGA DO EXEMPLAR CORRIGIDO DA DISSERTACC̃̃O/TESE Termo de Ciência e Concordância do (a) orientador (a)
}

\author{
Nome do (a) aluno (a): ELISA PLATZECK LEONARDI \\ Data da defesa: 29 / 03 / 2019 \\ Nome do Prof. (a) orientador (a): ADRIANO SCATOLIN
}

Nos termos da legislação vigente, declaro ESTAR CIENTE do conteúdo deste EXEMPLAR CORRIGIDO elaborado em atenção às sugestões dos membros da comissão Julgadora na sessão de defesa do trabalho, manifestando-me plenamente favorável ao seu encaminhamento e publicação no PortaL Digital de Teses da USP.

São Paulo, 28 / 05 / 2019

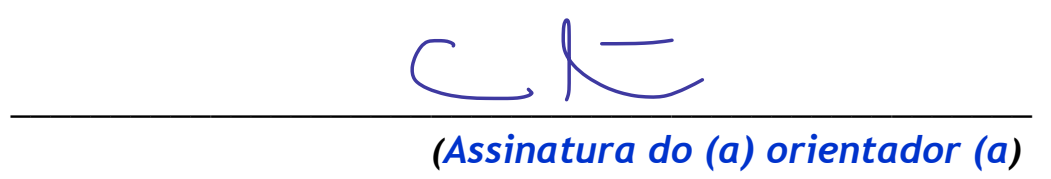


O presente trabalho foi realizado com o apoio da Coordenação de Aperfeiçoamento de Pessoal de Nível Superior - Brasil (CAPES) Código de Financiamento 001.

This Study was financed in part by the Coordenação de Aperfeiçoamento de Pessoal de Nível Superior - Brasil (CAPES) Finance Code 001. 


\title{
Resumo
}

Esta tese divide-se em duas partes. A primeira apresenta uma análise da invenção retórica no terceiro livro da Institutio Oratoria de Quintiliano. Essa primeira parte contém quatro capítulos, cujo conteúdo encontra-se assim distribuído: 1) a invenção retórica no livro 3 da Institutio; 2) a classificação dos genera causarum; 3) a teoria dos estados de causa; 4) conclusão e considerações finais, a contribuição de Quintiliano. A segunda parte consiste na tradução do livro 3 da Institutio Oratoria em língua portuguesa.

Palavras-chave:

Quintiliano, Hermágoras, retórica antiga, invenção, status

\begin{abstract}
The present thesis has two parts. Part one presents an analysis concerning the rhetorical inventio in book 3 of Quintilian's Institutio Oratoria. Its content is distributed in three chapters: 1) The rhetorical inventio in Institutio's third book; 2) The genera causarum classification; 3) The status-theory; and the conclusion. Part two presents a translation into Portuguese of Institutio's book 3.
\end{abstract}

Keywords:

Quintilian. Hermagoras, ancient rhetoric, inventio, status 
Agradecimentos

Ao Prof. Dr. Adriano Scatolin, pela orientação, pela confiança e pela paciência.

À Profa. Dra. Charlene Martins Miotti e à Profa. Dra. Isabella Tardin Cardoso, que compuseram a banca do exame de qualificação desta tese, cujos comentários e sugestões foram enriquecedores para a pesquisa.

À Coordenadoria de Aperfeiçoamento de Pessoal de Nível Superior (CAPES), pela bolsa de estudo para a pesquisa do doutorado.

A Miguel Ángel Díaz Guervós, por tudo. 


\section{Lista de Quadros}

Quadro 1 Classificação de Aristóteles segundo a audiência e o tempo ........... 34

Quadro 2 Classificação de Quintiliano de acordo com o lugar ........................ 37

Quadro 3 Classificação de Quintiliano de acordo com o assunto ................... 37

Quadro 4 Retórica a Alexandre I ................................................................. 42

Quadro 5 Retórica a Alexandre 2 ................................................................. 43

Quadro 6 Esquema da doutrina dos status de Quintiliano .......... 63

Quadro 7 Sistema das stáseis na Institutio Oratoria ................. 93 


\section{Sumário}

Introdução

Parte I

Capítulo 1 A invenção retórica no livro 3 na Institutio Oratoria ......... 11

1.1 Sobre os autores de retórica ............................................................... 14

1.2 A origem da retórica ..................................................................... 17

1.3 As partes da retórica ...................................................................... 18

1.4 Gêneros do discurso ................................................................... 20

1.5 Classificação das questões .............................................................. 21

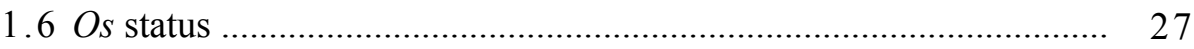

Capítulo 2 A classificação dos gêneros de causa na Institutio Oratoria 32

2.1 Os três gêneros de causa em Aristóteles ............................................... 32

2.2 A classificação dos gêneros em Anaxímenes .................................... 38

2.3 Elogio e vitupério em Isócrates ........................................................ 44

2.4 A tripartição dos gêneros de causa em Cícero ................................. 47

2.5 A divisão dos gêneros oratórios em Quintiliano .............................. 51

2.5.1 Gênero epidítico .................................... 51

2.5.2 Gênero deliberativo .................................... 54

Capítulo 3 A teoria dos estados de causa ........................... 59

3.1.Quid sit status ........................................... 59

3.1.1. O sistema dos status na Institutio Oratoria ........... 61

3.1.1.1. Status gerais ....................................... 65

3.1.1.1.1. Conjectura ...................................... 69

3.1.1.1.2. Definição ........................................ $\quad 74$

3.1.1.1.3. Qualidade.................................... 77

3.1.1.2. A questão legal ...................................... 81

3.1.1.2.1. Letra da lei e intenção.............................. 81

3.1.1.2.2. Leis em contradição .............................. 83

3.1.1.2.3. Silogismo ...................................... 85

3.1.1.2.4. Ambiguidade ................................. 87

3.1.2. Simulacros ......................................... 88

3.2. O sistema das stáseis de Hermágoras de Temnos na Institutio Oratoria ........................................ 91 
Parte II

Tradução Marco Fábio Quintiliano - A Formação do Orador (livro

113 3)

Texto latino 220

Bibliografia 288 


\section{Introdução}

A Institutio Oratoria, ou A Formação do Orador, de Quintiliano, expõe a técnica retórica segundo as perspectivas educacional, social e moral — tomando Cícero como modelo principal, Quintiliano põe seu conhecimento de retórica, como advogado e professor, a serviço da vida política romana. Embora seja a mais extensa obra sobre retórica latina que nos chegou, os estudos da Institutio concentram-se, sobretudo, em três de seus doze livros: o livro 1, sobre as primeiras aulas de gramática, que discute o papel do mestre de letras; o livro 10, que apresenta uma revisão da literatura antiga; o livro 12, onde se constrói o retrato do orador perfeito. Jorge Fernández López (2010, p. 307) vê na extensão da obra ("que vai muito além da maioria dos manuais") e no descrédito da retórica como disciplina no período imperial romano as razões para que o restante da obra seja negligenciado por estudiosos modernos. Fernández López, no entanto, destaca que, ao lado de Cícero, Quintiliano é o autor que nos proporciona o melhor panorama da retórica em Roma.

Estruturalmente, é possível dizer que a obra divide-se em três grandes partes: a instrução da criança junto ao mestre de primeiras letras, a educação do jovem na disciplina retórica e a formação moral do orador perfeito. A discussão a respeito da disciplina retórica tem início na segunda metade do livro 2, quando Quintiliano passa a dissertar sobre a necessidade de aprender retórica (2.11-12), o que é a retórica (2.15), qual sua utilidade (2.16), e ainda se é uma arte e que tipo de arte (2.17-18), se é uma virtude (2.20) e quais são sua matéria e seu método (2.11-21).

O livro 3, objeto deste trabalho, começa com o que seria uma introdução à arte do discurso, ou seja, prepara o aprendiz para o conteúdo que será apresentado na sequência. Em sua exposição, Quintiliano segue a divisão tradicional da retórica em cinco partes: invenção, disposição, elocução, memória e pronunciamento. O tratamento da inventio tem início no terceiro livro da Institutio e segue até o sexto livro.

Em nosso trabalho tentaremos demonstrar como Quintiliano trabalha a interseccionalidade entre a teoria aristotélica dos gêneros do discurso e a disciplina das stáseis de Hermágoras de Temnos, propondo uma terceira via para explicar a arte 
retórica. Embora Quintiliano afirme que não possa dar uma contribuição pessoal nesta área, pois muito já se falou sobre o assunto (3.1.5), tentaremos demonstrar que, no que tange a esses pontos, a Institutio Oratoria inova em seu tratamento da invenção retórica.

A análise da inventio no terceiro livro da Institutio constitui o primeiro capítulo desta tese. Seguindo a ordem apresentada por Quintiliano, examinaremos os temas discutidos em cada capítulo desse livro, que preparam o terreno para explicar o que se considera seu cerne, a saber, a divisão dos gêneros do discurso e o sistema das questões de direito e dos estados de causa, que constituirão, respectivamente, o segundo e o terceiro capítulos da tese. Para encerrar nosso estudo, apresentaremos considerações finais, que nos permitem extrair algumas conclusões sobre a opinião de Quintiliano no que tange à abordagem inicial para a invenção retórica na Institutio Oratoria.

A tese contém ainda uma segunda parte, que é a tradução anotada do livro 3 da Institutio Oratoria. Utilizamos o texto latino estabelecido por Jean Cousin para a coleção "Les Belles Lettres", cotejando-o com o texto de Donald A. Russell para a edição Loeb, citados na bibliografia. Para a anotação da tradução, servimo-nos das notas de ambas as edições, acrescentanto observações que nos pareceram relevantes para nossa análise e utilizando os comentários do terceiro livro, também citados na bibliografia.

Títulos de obras latinas e gregas foram vertidos para o português na tradução; nas notas foram adotadas as abreviações do Oxford Latin Dictionary e do Greek English-Lexicon (Liddell \& Scott).

Para o termo status, optamos por manter sua forma original em latim, em itálico, ao longo da tese, tanto em nossa análise quanto na tradução. Diante das alternativas de tradução "constituição" e "estados de causa", julgamos status mais adequada por manter a forma utilizada por Quintiliano, reservando "estado de causa" para designar o status principal de uma causa, como faz o autor estudado. 


\section{PARTE I}

\section{Capítulo 1}

\section{A invenção retórica no terceiro livro da Institutio Oratoria}

\footnotetext{
"Invenção é a investigação de argumentos verdadeiros ou verossímeis, que possam tornar provável uma causa."

(Cícero. Inv. 1.9. Inventio est excogitatio rerum verarum aut veri similium, quae causam probabilem reddant)
}

É possível que o tratado De Inventione, de Cícero, tenha sido referência para Quintiliano na introdução da invenção retórica no terceiro livro da Institutio, que distribui seu conteúdo de forma semelhante à do manual ciceroniano. A exposição da matéria começa com uma breve história da eloquência, definindo-a e determinando suas funções e seus objetivos, seguindo-se da classificação dos discursos em três gêneros (demonstrativum, deliberativum e iudiciale) e da divisão da arte (inventio, dispositio, elocutio, memoria, pronuntiatio).

Segundo o comentador Herman W. Taylor (1971, p. 2), abordar questões gerais no início dos tratados, como uma pequena introdução, parece ser prática anterior a Cícero, observada também no tratado anônimo Rhetorica Rhet.Her.ennium e na Retórica de Aristóteles ${ }^{1}$, mas a Institutio Oratoria destaca-se pela extensão e pelo detalhamento das questões introdutórias.

George A. Kennedy (1962, p. 132) esclarece que a extensa obra de Quintiliano é um sistema de treinamento, pensado para o grammaticus ("professor de primeiras letras”) e para o rétor. Ao adotar a concepção do orador perfeito, a Institutio Oratoria estende o terreno da arte oratória à educação, pois, mesmo que a retórica já fizesse parte da educação dos jovens, antes da Institutio não era praxe que os manuais tratassem da primeira etapa da educação de crianças.

\footnotetext{
1 Cf. Rhet.Her. 1.2-4. Embora de forma mais dispersa, questões gerais como natureza, objetivo, definição e usos da retórica estão presentes nos dois primeiros capítulos da Retórica (Arist. Rh. 1354a-1356b33).
} 
De acordo com o que Pierre Chiron (2007) denominou "tipologia dos tratados greco-latinos", a Institutio é um exemplo característico de "tratado 'total', ao mesmo tempo de retórica e educação"; inserido no grupo dos "tratados generalistas", esse tipo teria um público variado, desde um aprendiz que busca orientações para elaborar um discurso até um rétor que reúne material para preparar um curso. Os "tratados generalistas", segundo Chiron (2007, p. 101 ss.), têm “objetivo prático e imediato (fazer um discurso) até um tratado de educação”.

O caso da Retórica de Aristóteles - embora conste entre os tratados generalistas - é um pouco diferente, porque o destinatário era um aprendiz não só de retórica, mas de filosofia, que procurava saber não apenas como se faz um discurso, mas também o processo de funcionamento desse discurso. Chiron (2007, p. 103) chama a atenção para o fato de que a noção aristotélica de technè (estrutura sistemática, definições com terminologias unívocas, foco no funcionamento do procedimento, associação dos meios utilizados e objetivos buscados etc.) submeteria a retórica e o artífice a condições restritivas, mas o termo grego technè significa conhecer um ofício. Donde, de modo geral, os tratados de retórica devem ser vistos como inseridos num projeto de ensino metódico da produção oratória segundo alguns princípios, apresentando estrutura menos rígida e tratando de matéria empírica ${ }^{2}$. Esse conjunto de produção técnica no domínio retórico compõe os "tratados abertos e evolutivos" (CHIRON, 2007, p. 102). Essa plasticidade — termo de Chiron - e uma capacidade de evolução devem-se a determinados fatores, dentre os quais as condições políticas ("não se teoriza a comunicação pública da mesma maneira quando se escreve na Atenas democrática e em Roma sob Domiciano", explica Chiron (ibid.), a influência aristotélica e isocrática. Particularmente, a influência de Isócrates fez com que a retórica deixasse de ser somente uma técnica, passando a ser a "principal mola propulsora da civilização" (id., ibid.). Por consequência, nesse contexto surge o "tratado de educação", destinado, pelo rétor que o escreve, tanto ao colega como ao aluno. A concepção da

\footnotetext{
$2 \mathrm{Na}$ tipologia dos tratados proposta por Pierre Chiron (2007), "generalistas" dividem-se em quatro tipos: a) "discurso-modelo" (ex.: Tetralogias de Antifonte); b) "tratado descritivo do produto final" (ex.: Apsines); c) "tratado-método" (ex.: Retórica de Aristóteles); d) "tratado "total', ao mesmo tempo de retórica e de educação" (ex.: Institutio Oratoria de Quintiliano). Os tratados "especializados" também são quatro: a) "algoritmo" (ex. Hermágoras); b) "tipologia" (ex. Do estilo de Ps- Demétrio de Falera); c) "repertório" (progumnasmata); "taxonomia" (tratado de figuras).
} 
retórica como meio de formação do cidadão está presente na obra de Cícero e Quintiliano, e influenciou a maneira de apresentar a técnica.

Na Institutio Oratoria a formação do orador começa ainda na infância, com o ensino das primeiras letras e aulas iniciais junto ao grammaticus, conteúdo dos dois primeiros livros da obra.

No proêmio do livro 1 da Institutio (1.1-2), Quintiliano informa que a proposta de seu trabalho não é tanto oferecer algum método novo, como fazer uma apreciação das teorias de seus antecessores, muitas vezes conflitantes e contraditórias, pois muito já se escreveu sobre o método do discurso, e ele pretende, na medida do possível, indicar ao jovem aprendiz o caminho que lhe pareça mais adequado seguir.

A discussão sobre a arte retórica tem início ainda no segundo livro, a partir de sua segunda metade (2.15.1), quando Quintiliano define retórica, reconhece sua utilidade, explicando tratar-se de uma arte e, ao mesmo tempo, de uma virtude, atribuindo-lhe "como matéria todos os assuntos sobre os quais é preciso falar" (3.1.1. materiamque ei res omnes, de quibus dicere oporteret). Com o terceiro livro, Quintiliano abre sua explanação do "método da invenção e da disposição do material elencado" (8.1.1. ratio inveniendi atque inventa disponendi), assunto dos livros 3 a 7 da obra.

O conteúdo dos três primeiros capítulos do livro 3 funciona como uma introdução à inventio. Nosso autor explica que em outras partes da obra buscou fazer uso de "alguma graça" (3.1.3. aliquid nitoris) para tornar a matéria mais atraente aos jovens, mas teme que "este livro possa ter pouco mel e muito absinto" (3.1.5 ne parum hic liber mellis et absinthii multum habere videatur) e adverte que seu conteúdo será uma matéria árida, "posto que praticamente requer uma mera exposição de regras" (3.1.2. quippe quod prope nudam praeceptorum traditionem desideret). Além disso, Quintiliano declara merecer "pouco crédito por este livro" (3.1.5. ex eo minorem gratiam), pois seus temas já foram tratados por muitos autores, e explica ter seguido uma linha de raciocínio que nem sempre coincide com a de alguns rétores, sendo natural haver discordâncias entre as autoridades no assunto. No final do primeiro capítulo, ele esclarece ter manifestado opinião própria sobre alguns pontos e ter reunido "em um único trabalho um extenso material, encontrado em muitos autores" (3.1.22. sicut ipse 
plurium in unum confero inventa), oferecendo-o a seus leitores para que eles próprios fizessem suas escolhas.

A parte técnica da invenção retórica, seus princípios e suas regras, é apresentada a partir do quarto capítulo do livro 3, com a classificação dos gêneros de discurso, e ocupa os três livros seguintes. Porém, antes de entrarmos na análise do tratamento da invenção, vejamos como nosso autor faz sua introdução ao tema.

\subsection{Sobre os autores de retórica}

O primeiro capítulo é dedicado às autoridades na eloquência. São citados Córax e Tísias, "os mais antigos autores de manuais" (3.1.8), seguidos por Górgias, Protágoras, Trasímaco, Isócrates, Aristóteles, Teofrasto, Apolodoro e Teodoro, entre outros autores gregos. Dentre os autores romanos, Quintiliano cita, primeiro, Marco Catão, depois Marco Antônio e seu grande modelo, Cícero:

20. Praecipuum vero lumen sicut eloquentiae, ita praeceptis quoque eius, dedit unicum apud nos specimen orandi docendique oratorias artes M. Tullius, post quem tacere modestissimum foret, nisi et rhetoricos suos ipse adulescenti sibi elapsos diceret, et in oratoriis haec minora, quae plerumque desiderantur, sciens omisisset. "Inigualável brilho - tanto na prática da eloquência como nos seus ensinamentos - produziu aquele que, entre nós, foi modelo único do discurso e do ensino das artes oratórias: Marco Túlio. Depois dele o mais razoável seria permanecer em silêncio, não fosse o fato de ele mesmo afirmar que a sua retórica lhe escapou das mãos, e que intencionalmente omitiu nos seus textos sobre oratória pequenos detalhes que tantas vezes fazem falta."

Sem dúvida alguma, Cícero é a principal fonte de Quintiliano, tanto na teoria como na maneira de escrever (modus scribendi) ${ }^{3}$. As obras ciceronianas de que

\footnotetext{
3 George A. Kennedy (1962, p. 134 ss.) explica que Quintiliano rechaçava a elocução inflada da época. Assim como os excessos eram combatidos pelos Flávios em outras áreas, o apreço a Cícero faria parte dessa reação: além de um genus dicendis mais aticista (por oposição ao asianismo de Sêneca), a figura do bonus ou perfectus orator presente na Institutio oferecia um contrapeso aos filósofos, o que iria ao encontro dos interesses dos Flávios (década de 70 d.C.), que expulsaram os filósofos de Roma porque seus ensinamentos eram vistos como corruptores dos costumes romanos.
} 
Quintiliano se serviu são: De Inventione, De Oratore, Partitiones Oratoriae, Brutus, Orator e Topica. Eram tão bem conhecidas por Quintiliano a ponto de ele citá-las de memória. Embora tenha sido seu modelo no arranjo da matéria, a obra de juventude de Cícero - o De Inventione - tem seu conteúdo questionado por Quintiliano, que muitas vezes a deixa de lado quando não corresponde a sua opinião, alegando a imaturidade daquele autor e aproveitando que o próprio Cícero tenha criticado esse texto de sua juventude 4 .

O comentador Joachim Adamietz (1996, pp. 10-12) observa que é sobretudo no livro 3 que Quintiliano critica e até mesmo corrige Cícero, porém "as obras retóricas de Cícero não apenas estão presentes em muitos exemplos e fontes, mas fornecem também uma forma de apreciação da obra de Quintiliano" (ADAMIETZ, 1996, p. 12). Por exemplo, na Institutio, Aristóteles é mencionado com frequência, especialmente no livro 3, e esse dado representaria muito provavelmente uma retomada da tradição aristotélica, seguindo o modelo de Cícero ${ }^{5}$. As informações que Quintiliano atribui a Aristóteles são em parte corretas, em parte imprecisas ou claramente incorretas. Os erros, segundo Adamietz (ibid.), são de tal maneira evidentes que nos levam a crer terem surgido de leituras indiretas, sem consulta aos textos originais de Aristóteles. Mas a questão do acesso às fontes, neste caso, pode ser deixada em segundo plano, tendo em vista que o que é relevante aqui é a reafirmação da tradição retórica. Através do resgate de autores e teorias disponíveis, Quintiliano selecionou o material para escrever sobre a educação do orador.

\footnotetext{
4 No início do diálogo Do Orador I,5 Cícero assim se manifesta sobre seus textos da juventude: 5. Vis enim, ut mihi saepe dixisti, quoniam quae pueris aut adolescentulis nobis ex commentariolis nostris inchoata ad rudia exciderunt, uix hac aetate digna et hoc usu, quem ex causis, quas diximus, tot tantisque consecuti sumus, aliquid eisdem de rebus politius a nobis perfectiusque proferri: solesque nonnunquam hac de re a me indisputationibus nostris dissentire, quod ego prudentissimorum hominum artibus eloquentiam contineri statuam; "Ora, como me disseste várias vezes, pretendes, pelo fato de os escritos que escaparam incompletos e grosseiros de meus apontamentos, quando era menino ou, antes, adolescente, mal serem dignos desta nossa idade e desta experiência, granjeada em tantas e tão importantes causas defendidas, que publique algo mais refinado e acabado acerca do mesmo tema" (Trad. Adriano Scatolin. Cf. bibliografia).

5 Em suas obras Da Adivinhação, Do Orador, Bruto e Orador, Cícero apresenta-se aparentemente como seguidor de Aristóteles e Teofrasto, ambos muito citados (cf. Adamietz, p. 9). Fortenbaugh (1989, p. 40) ressalta que, no $D a$ Invenção, Cícero endossa a visão de Aristóteles, mas não explicita ter conhecido diretamente a Retórica; tudo o que apresenta em sua primeira obra teria sido aprendido de seus mestres, a partir de manuais.
} 
No primeiro capítulo, a lista de rétores ou autoridades em retórica segue uma ordem cronológica, desde os mais antigos (Górgias e Córax), destacando, entre os gregos, Protágoras e Górgias, "os primeiros a tratar dos lugares-comuns" (3.1.12. horum primi communis locos tractasse), Isócrates - "o mais brilhante discípulo de Górgias" (3.1.13. clarissimus Gorgiae auditor) — e seus discípulos. Dessa mesma época, é mencionado Aristóteles e também seu discípulo Teofrasto. Contemporâneos deste último, "os principais estoicos e peripatéticos, que se aprofundaram muito mais no assunto do que os próprios rétores" (3.1.15. atque hinc vel studiosius philosophi quam rhetores praecipueque stoicorum ac peripateticorum principes). Posteriormente veio Hermágoras, seguido de Apolônio Mólon, Areu, Cecílio, Dionísio de Halicarnasso.

Ainda entre os gregos, "rétores que efetivamente despertaram interesse" (3.1.17. praecipue tamen in se converterunt studia) foram Apolodoro de Pérgamo e Teodoro de Gádara — segundo Quintiliano, "tinham opiniões muito particulares" (3.1.18. hi diversas opiniones tradiderunt) —, cujos seguidores designavam-se apolodorianos e teodorianos. Do primeiro, é possível conhecer seus preceitos através de seus discípulos, Gaio Válgio, em latim, e Ático, em grego; do segundo, existem mais obras e também um discípulo dele, que foi Hermágoras (o jovem). O interesse de Quintiliano por essas duas escolas possivelmente se deve à ênfase dos apolodorianos na inventio, incluindo a teoria dos status, e na dispositio. Por outro lado, Quintiliano critica a postura de Apolodoro, que restringe o objeto da oratória ao âmbito judicial, com uma visão estritamente utilitária:

2.15.12. Atqui non multum ab hoc fine abest Apollodorus dicens "iudicialis orationis primum et super omnia esse persuadere iudici et sententiam eius ducere in id quod uelit".

"Definição não muito distante da de Apolodoro, quando diz: 'um discurso judicial deve, antes e acima de tudo, persuadir o juiz e influenciar seu veredicto para que seja o que se espera'."

Dos teodorianos, Quintiliano apreciaria a definição de Teodoro de Gádara para retórica, que abarca um campo mais amplo do que o terreno dos tribunais: 
2.15.21. "Ars inventrix et iudicatrix et enuntiatrix, decente ornatu secundum mensionem eius quod in quoque potest sumi persuabile, in materia civili".

"Uma arte de inventar, julgar e expressar-se, com ornamentos adequados, de acordo com a dimensão do tema, e que possa circunscrever o que quer que seja persuasivo em cada caso, em matéria que envolve cidadãos."

A lista de autoridades romanas começa com Catão, "o primeiro a tratar dessa matéria" (3.1.19. condidit aliqua in hanc materiam). Ortega Carmona (2001, p. 68 ss.) observa que Quintiliano guiou-se pela sentença “o orador é um homem de bem, versado no discurso" (vir bonus dicendi peritus), de Catão, citada no proêmio do livro 12 da Institutio, na "sua pretensão de configurar a personalidade do orador perfeito" (ibid). Esse princípio seria seguido na educação desde a primeira infância até a escola de oratória, onde são ensinados não apenas técnicas de oratória, mas também fundamentos sobre ética.

Depois de Catão, Quintiliano cita Marco Antônio e comenta que "restou dele um único texto, e mesmo assim incompleto" (3.1.19. hoc solum opus eius atque id ipsum imperfectum manet), mas digno de ser citado; quanto aos seguintes, esclarece Quintiliano, "são menos conhecidos, mas não deixarei de mencioná-los em algum momento, se o assunto exigir" (3.1.19. secuti minus celebres, quorum memoriam, si quo loco res poscet, non omittam).

Na sequência, temos Marco Túlio (3.1.20), na passagem citada no início deste tópico (p. 13 desta tese). Depois de Cícero, Quintiliano nomeia alguns autores de manuais e professores de retórica romanos, evitando o nome dos vivos; encerra o capítulo 1, informando que "mesmo depois de tantas e tão importantes autoridades, não hesitarei em manifestar minha opinião sobre alguns pontos" (3.1.22. non tamen post tot ac tantos auctores pigebit meam quibusdam locis posuisse sententiam).

\subsection{A origem da retórica}

A origem da retórica é tema do breve capítulo 2, "uma questão que não deve tomar muito tempo" (3.2.1. nec diu nos moretur quaestio). De acordo com Quintiliano, o motivo de defender-se pode ser o mais honroso, mas não foi necessariamente o 
primeiro que levou homens a desenvolverem sua capacidade de expressão. Assim, a natureza nos proporciona o dom da fala, a utilidade da linguagem desperta interesse em estudá-la e aperfeiçoá-la, os exercícios e a metodologia culminam no apogeu da eloquência. Sobre os conceitos natura, exercitatio e ratio, Quintiliano constrói sua concepção de arte retórica ${ }^{6}$, que não é mera imitação do observado, mas um conjunto de princípios abstraídos da prática e comprovados no uso. Quintiliano conclui o capítulo, discordando de Cícero: este "atribuía a origem da oratória aos fundadores das cidades e aos legisladores, que precisavam contar com o poder do discurso" (3.2.4. initium orandi conditoribus urbium ac legum latoribus dedit, in quibus fuisse vim dicendi necesse est), porém, observa Quintiliano, “existem povos nômades sem cidades nem leis que atuam como embaixadores, fazem acusações e defesas" (3.2.4.vagae et sine urbius ac sine legibus gentes, et tamen qui sint in iis nati et legationibus fugantur et accusent aliqua atque defendant).

\subsection{As partes da retórica}

O terceiro capítulo é dedicado às partes da retórica. Acatando "a maioria das autoridades" (plurimi maximeque auctores), Quintiliano adota a divisão e ordem canônicas das cinco partes. Posto que "todo discurso necessariamente precisa conter um conceito (rem, objeto da invenção) e uma formulação" (verba, objeto da elocução), o que e como dizemos têm que ter um lugar certo, daí a disposição. A quarta parte é a memória, que auxilia as três anteriores, e, por fim, o proferimento. A primeira parte, ou seja, a invenção, trata do assunto ou matéria (res), sua formulação (verba) é explicada na elocução, a terceira parte, se seguirmos a ordem tradicional: invenção, disposição, elocução, memória e proferimento.

Embora George A. Kennedy (1999, p. 99) seja categórico em dizer que "Hermágoras é a mais antiga fonte conhecida do tratamento das cinco partes da retórica", podemos afirmar apenas que essa classificação foi amplamente adotada no

\footnotetext{
${ }^{6}$ Essa concepção é retomada na discussão sobre as questões em 3.5.1.
} 
período helenístico. Em consonância com essa tendência, também os primeiros tratados $\operatorname{latinos}^{7}$ que nos chegaram adotaram essa partição.

Alguns autores, no entanto, atribuíram essas cinco partes às tarefas (opera) do orador, que deve encontrar, dispor, expressar, memorizar e proferir. Quintiliano discorda: "se aceitarmos essa ideia, não deixaremos nada para a arte" (3.3.11. quod si accipimus, nihil arti relinquemus); e esclarece: "cabe ao orador discursar bem, mas a ciência de discursar bem ainda é retórica" (3.3.12. bene dicere est oratoris, rhetorice tamen erit bene dicendi scientia).

Quintiliano não se detém na explicação em detalhe de cada parte, posto "que todo discurso é composto por conceitos e palavras" (3.1.5. sermo...habeat necesse est rem et verba), a invenção e a elocução se aplicam a todo discurso, mas quando os discursos são mais longos é necessário analisar em que lugar dizer cada coisa, contando com a ajuda da memória. O estudo do proferimento é essencial para uma atuação adequada. Ao estudo de cada parte da retórica é dedicado um espaço na Institutio, onde se examina particularmente a teoria referente ao tema8.

Ao esclarecer que não se deve considerá-las tarefas do orador, mas partes da arte, Quintiliano elimina a confusão de alguns autores, que denominaram partes da retórica a laudativa, a deliberativa e judicial, "mas se essas são partes, são antes partes da matéria que da arte" (3.3.14. quae si partes sunt, materiae sunt potius quam artis), como explica:

\subsubsection{Namque in his singulis rhetorice tota est, quia et inventionem et dispositionem et elocutionem et memoriam et pronuntiationem quaecumque earum desiderat. itaque quidam genera tria rhetorices dicere maluerunt, optime autem ii, quos secutus est Cicero, genera causarum. \\ "Sem dúvida, em cada uma delas está presente a retórica como um todo, uma vez que cada uma requer a invenção, a disposição, a elocução, a memória e o}

\footnotetext{
7 Na Retórica a Herênio, o autor classifica as cinco partes como "tarefas do orador": Rhet.Her.. 1.3. Oportet igitur esse in oratore inventionem, dispositionem, elocutionem, memoriam, pronuntiationem. Cícero, no Da Invenção, denomina "partes", como qualificou "a maioria das autoridades": Inv.1.9. partes autem eae, quas plerique dixerunt, inventio, dispositio, elocutio, memoria, pronuntiatio. Nas Partições (Part. 3), Cícero divide a habilidade (vis) do orador em res e verba, que devem ser encontradas, expressas com palavras, voz e gestos, dispostas e guardadas. A divisão em 5 partes também está no Sobre o Orador (De Orat.1.142 e 2.79) e no Bruto (Brut.215).

8 As partes da retórica encontram-se na Institutio Oratoria nos seguintes lugares: Inventio (livros 3 a 6), dispositio (livro 7), elocutio (livro 8 a 11.1), memoria (11.2), pronuntiatio (11.3).
} 
proferimento. Sendo assim, alguns autores preferiram chamá-las 'os três gêneros da retórica', mas a melhor classificação foi daqueles que Cícero seguiu, denominando-as 'gêneros de causa'."

\subsection{Gêneros do discurso}

As regras da invenção propriamente dita são explicadas a partir do quarto capítulo, começando com a classificação dos gêneros do discurso (ou da causa). Primeiro, Quintiliano expõe distintas opiniões acerca do assunto, para acabar adotando a tripartição aristotélica, ou seja, os três gêneros de discurso: deliberativo, judicial e epidítico - divisão presente também nos tratados ciceronianos De Inventione e De Oratore, além do anônimo Rhetorica Rhet.Her.ennium.

Jon Hesk (2009, p. 146) observa que, embora Aristóteles tenha servido de referência para a subsequente teoria e prática helenística e romana, autores posteriores o criticaram por limitar sua teoria ao contexto da pólis clássica. Particularmente, Quintiliano foi crítico da sistematização limitadora da tripartição da oratória. $\mathrm{Na}$ Institutio Oratoria, a matéria é atualizada, com a proposta de uma ampliação do campo da oratória, pois "os pioneiros no assunto restringiram a um campo tão limitado um material tão vasto" (3.4.4. priores rem tam late fusam tam breviter adstrinxerint), e uma intersecção entre os gêneros do discurso, "já que, de certa maneira, todos se apoiam mutuamente" (3.4.16. stant enim quodam modo mutuis auxiliis omnia). Por essa razão, depois de expor a doutrina dos estados de causa, ele dedica um capítulo a cada gênero9, complementando a ideia de que, qualquer que seja o tipo de discurso, nos servimos de toda a matéria, ou seja, num discurso demonstrativo elogiamos ou vituperamos, abordamos questões jurídicas, do passado, do presente ou do futuro. Isso se aplica aos três gêneros. Essa reformulação da clássica tripartição dos discursos é uma das contribuições de Quintiliano para o ensino da retórica, sendo tema do próximo capítulo desta tese, em que analisaremos mais amplamente a classificação dos gêneros.

Segundo Hesk (2009, p. 161), a classificação aristotélica dos gêneros de discurso é limitada e foi amplamente contestada; nem seus contemporâneos nem seus sucessores concordavam necessariamente com a divisão tripartida e suas operações.

\footnotetext{
${ }^{9}$ Capítulo 7, demonstrativo; capítulo 8, deliberativo; capítulo 9, judicial.
} 
Apesar disso, o esquema aristotélico permaneceu como uma ferramenta útil de classificação, sendo difícil prescindir dela, posto que é muito eficaz na compreensão de muitas instâncias retóricas desde a Antiguidade até hoje. O estudioso conclui:

"Quando vemos versões escritas de exemplos reais de oratória deliberativa, forense e epidítica da Grécia e de Roma, com frequência observamos que eles têm muito mais coisas que não podem ser explicadas com base na classificação de Aristóteles, nem - o que realmente importa — com base na classificação oferecida por nenhum outro pensador da retórica." (ibid.)

\subsection{Classificação das questões}

No capítulo 5, Quintiliano trata, de modo geral, daquilo em que consiste o método de discursar. Esse capítulo nos interessa em especial porque seu conteúdo é requisito para compreender o tema central do livro 3, que é o sistema dos status. Para entendê-lo, antes de mais nada, é preciso definir as questões de fato e as questões de direito.

Primeiro, "entre as autoridades mais eminentes", afirma Quintiliano, "há um consenso de que em retórica determinadas coisas exigem comprovação e outras, não" (3.5.3. praestantissimis auctoribus placet alia in rhetorice esse, quae probationem desiderent, alia quae non desidernt, cum quibus ipse consentio). As primeiras se incluem no gênero judicial, as outras, no demonstrativo e deliberativo. Também "todos concordam", explica, que "as questões se apoiam ou em algo escrito ou em algo não escrito" (3.5.4. illud omnes fatentur, esse quaestiones aut in scripto aut in non scripto). Desse modo, as questões que se apoiam em algo escrito são questões de direito e foram denominadas "legais" (vouıkóv) por Hermágoras e seus discípulos; as que têm relação com algo não escrito são questões de fato, denominadas "racionais" ( $\lambda$ oүıкóv) por esses rétores gregos.

Outros autores apresentam também bipartições, mas de maneiras distintas: questões relacionadas a fatos e questões relacionadas a palavras; ou, ainda, questões definidas e indefinidas. Enquanto os gregos chamaram "hipótese" a questão definida e "tese", a indefinida, os latinos denominaram "causa" a questão definida, que "gira em 
torno de coisas e pessoas", também chamada "questão específica", e a indefinida apresenta denominação variada, sendo chamada "questão pública universal" por alguns, "questão conveniente a um filósofo" por outros, "partes da causa" por Ateneu.

Taylor Jr. (1971, p. 156) reconhece que a definição de Ateneu para tese como pars causae é a que mais se aproxima dos termos propostos por Hermágoras, coincidindo com o ponto de vista de Cícero no Partitiones Oratoriae, sobre o gênero das questões:

[61] CF. Quoniam et de ipso oratore et de oratione dixisti, expone eum mihi nunc quem ex tribus extremum proposuisti, quaestionis locum.

CP. Duo sunt, ut initio dixi, quaestionum genera, quorum alterum finitum temporibus et personis, causam appello, alterum infinitum nullis neque personis neque temporibus notatum propositum voco. Sed est consultatio quasi pars causae quaedam et controversiae: inest enim infinitum in definito, et ad illud tamen referentur omnia.

"C.F. Como já trataste do orador em si e do discurso, fala agora sobre o último dos três temas que havias proposto: a parte das questões.

C.P. Como afirmei no início, são dois os gêneros de questões, um é limitado, envolvendo épocas e pessoas, que eu chamo causa; outro, indefinido, sem épocas nem pessoas determinadas, que eu denomino tese. Um debate, no entanto, é como uma parte da causa e da controvérsia, sendo que o indefinido está contido no definido e todas as coisas se referem a ele."

A tese em Hermágoras, ainda segundo Taylor (ibid.), seria a abstração da hipótese, como um estratagema para descobrir os aspectos mais gerais da causa. Essa mesma ideia está presente na Institutio.

Seguindo em sua exposição, Quintiliano explica que Cícero chamou "proposição" a questão indefinida e dividiu-a em questões de conhecimento e questões de ação. Um exemplo da primeira: "se o mundo é governado pela Providência". Uma questão de ação: "se é preciso participar na administração pública"10. Ele estabeleceu três aspectos para a questão de conhecimento: "é ou não é”, “o que é”, "qual sua natureza" (3.5.6. "an sit”, "quid sit”, "quale sit”), podendo todos os três ser

10 Cf. 3.5.5-6. O exemplo da Providência não é de Cícero, mas de Quintiliano. A classificação de Cícero que Quintiliano menciona encontra-se em Tópicos (Top. 80) e Partições Oratórias (Part. Orat. 60-65). 
desconhecidos. A questão de ação, por sua vez, apresentaria dois aspectos: "de que modo obtemos o cargo", "como o utilizamos" ( "quo modo adipiscamur”, “quo modo utamur").

Essa bipartição das teses é apresentada no De Oratore (3.109-119), quando se discute que o terreno da oratória ficaria muito limitado se os filósofos tomassem as teses como matéria exclusiva deles. Cícero, então, na voz de Crasso, divide as teses em duas categorias: de cognição e de ação. O primeiro tipo visaria o conhecimento, e nele se aplicam os status de conjectura, definição e qualidade; o segundo seria de "caráter especulativo ou mais ético-prático", como explica Calboli Montefusco (1986, p. 45), que identifica nesse momento do diálogo uma crítica ao tecnicismo hermagoreano (presente no De Inventione), considerando que Cícero, muitas vezes, indicava uma aplicação indiscriminada dos status:

De Or. 3.111. Omnis igitur res eandem habet naturam ambigendi, de qua quaeri et disceptari potest, sive in infinitis consultationibus disceptatur sive in eis causis, quae in civitate et forensi disceptatione versantur; neque est ulla, quae non aut ad cognoscendi aut ad agendi vim rationemque referetur.

"Portanto, todo tema apresenta a mesma natureza de discussão, a respeito da qual é possível investigar e debater, quer se debata sobre discussões gerais, quer sobre as causas que concernem ao estado e a um debate forense, e não existe nenhum que não se refira à essência e ao método de conhecimento e de defesa."

Lucia Calboli Montefusco (p. 46 ss.) recorda que essa divisão ciceroniana das teses não alcançou significativa repercussão entre os rétores antigos e que somente na Institutio Oratoria (3.5.6) consta a bipartição das teses em genus cognitionis e genus actionis, com a sucessiva aplicação dos status an sit, quid sit, quale sit às teses teóricas. A estudiosa (ibid.) salienta que a citação explícita de Cícero como artífice dessa bipartição nos leva a pensar que Quintiliano tinha muito presentes todas as três obras de Cícero, nas quais está disposta essa teoria ${ }^{11}$.

A questão definida deriva da indefinida, "mais abrangente" (amplior), por isso classificada como "questão geral" (simplex/generalis). "De toda maneira", explica

${ }^{11}$ De Or. 3.109-119; Part. 62-67; Top. 81-86. 
Quintiliano, “em toda questão específica se inclui uma geral, já que o gênero é anterior à espécie" (3.5.9. in omni autem speciali utique inest generalis, ut quae sit prior).

A distinção das questões em infinitae (teses) e finitae (hipóteses) na Institutio não deve ser vista como uma mera retomada da doutrina de Hermágoras de Temnos. Calboli Montefusco (p. 49) avalia que essa diferenciação nas questões tem origem na doutrina peripatético-acadêmica, segundo a qual o orador deveria "abstrair o caso em questão pela limitação das circunstantiae, de modo que, uma vez demonstrado verdadeiro o caso geral, se conseguiria que também aquele particular fosse reconhecido como verdadeiro".

É possível considerar de caráter geral questões como: "é motivo para cometer um crime o ódio ou a cobiça?" (3.5.10. "an causa sceleris odium, cupiditas”), “deve-se acreditar em confissões obtidas sob tortura?" (3.5.10. “an tormentis credendum”). Além disso, alguns rétores interpretam teses e causas de forma diferente, por exemplo: "seria uma causa quando Orestes é acusado; uma tese, se Orestes foi absolvido com justiça" (3.5.11. ut causa sit, cum Orestes accusatur, thesis, an Orestes recte sit absolutus). A tese seria teórica, somente "para conhecer a verdade" (veritatis tantum gratia disputari); a causa, prática, pois "há um assunto particular a ser resolvido" (negotium agi). ${ }^{12}$

A propósito das questões gerais, Quintiliano refere-se ao seguinte comentário de Cícero, no De Inventione (1.8): "parece que Hermágoras não ouve o que diz nem entende o que propõe, ao dividir a matéria do orador em questões específicas (causam) e questões gerais (quaestionem)" (nam Hermagoras quidem nec quid dicat attendere nec quid polliceatur intellegere videtur, qui oratoris materiam in causam et in quaestionem dividat) ${ }^{13}$, incorporando-as à matéria oratória, como se ultrapassasse os limites da retórica ao incluir na arte questões universais, que seriam exclusividade da filosofia. Ainda segundo Cícero, parece que Hermágoras "seguro de seu conhecimento,

\footnotetext{
12 Cf. 3.5.10-11.

13 Em lugar de quaestiones especiales e quaestiones generales, Cícero emprega outra forma, mas com o mesmo sentido apresentado em Quintiliano. Cf. Inv. 8. causam esse dicat rem, quae habeat in se controversiam in dicendo positam cum personarum certarum interpositione; (...) quaestionem autem eam appellat, quae habeat in se controversiam in dicendo posita sine personarum interpositione. "Chama-se causa (ou questão específica) aquela que apresenta uma controvérsia envolvendo pessoas determinadas, (...) denomina-se questão (ou questão geral) aquela que apresenta uma controvérsia sem envolver pessoas determinadas".
} 
teria definido mal a função do orador e exposto suas próprias capacidades, não as da arte" (Inv. 1.8. fretus sua scientia falsum quiddam constituisse de oratoris artificio et non quid ars, sed quid ipse posset, exposuisse); por outro lado, Cícero reconhece que, na sua Retórica, Hermágoras compilou o melhor de tratados antigos e ainda apresentou "preceitos inovadores"14.

Esse comentário é relembrado por Quintiliano, quando menciona que livros atribuídos a Hermágoras, nos quais se considera que as questões gerais não têm utilidade para o orador, provavelmente seriam falsos ou de outro homônimo, "pois como poderiam ser desse mesmo autor, que escreveu coisas admiráveis sobre a arte retórica e que, como fica claro também no primeiro livro sobre retórica de Cícero, dividiu a matéria de retórica em teses e causas?" (3.5.14.nam eiusdem esse quo modo possunt, qui de hac arte mirabiliter multa composuit, cum, sicut ex Ciceronis quoque rhetorico primo manifestum est, materiam rhetorices in thesis et causas diviserit?).

"Contudo, ele me livrou do constrangimento de ter que responder a isto" (3.5.15. sed me liberauit respondendi verecundia), diz Quintiliano, explicando a mudança de opinião de Cícero a respeito das questões universais em obras posteriores ao $D e$ Inventione, quando defende que é preciso separar controvérsias de pessoas e circunstâncias específicas, "uma vez que”, explica Quintiliano, "é possível falar mais amplamente do geral do que do específico, e porque o que é comprovado no geral, necessariamente é comprovado no particular" (3.5.15. quia latius dicere liceat de genere quam de specie, et quod in universo probatum sit, in parte probatum esse necesse sit).

A maneira de compreender "tese" explicaria a crítica de Cícero a Hermágoras. No início do De Inventione, quando trata do objeto da retórica, Cícero refere-se à tese em um sentido distinto do proposto por Hermágoras, doutrina que define "tese", objeto da retórica, como uma questão restrita a um conteúdo ético-político, as $\pi$ o $\lambda i ́ \tau ı \kappa \alpha$

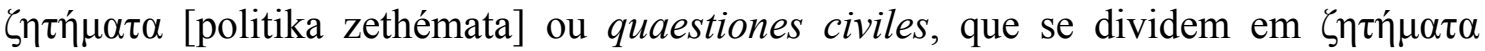

$14 \mathrm{Cf}$. Inv. 1.8. nam satis in ea uidetur ex antiquis artibus ingeniose et diligenter electas res collocasse et nonnihil ipse quoque novi protulisse. "Com efeito, parece que incluiu na [sua Retórica] informações de tratados antigos, selecionadas com cuidado e discernimento, tendo apresentado preceitos próprios inovadores". 


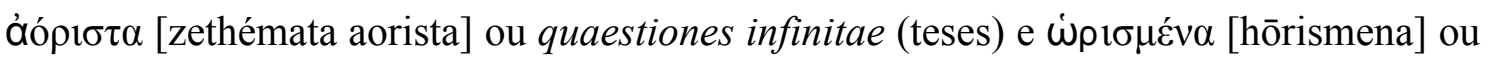
finitae (hipóteses); nessa doutrina as stáseis (status) são aplicadas somente às hipóteses.

$\mathrm{Na}$ doutrina peripatético-acadêmica, adotada por Cícero nas obras de maturidade, as teses, como já vimos, dividem-se em teóricas (ou de cognição) e práticas (ou de ação). Às teses teóricas — também denominadas quaestiones naturales — se aplicam os status de coniectura, finis e qualitas, tanto na filosofia quanto na retórica, e representam a abstração do particular, como mostramos no início deste tópico (pp. 20-21 desta tese), nas Partitiones (61): “o indefinido está contido no definido e todas as coisas se referem a ele".

Assim, as teses ou questões gerais podem ser explicadas também pela teoria dos status. Um exemplo: seria uma tese "se é preciso casar-se"; uma causa, "se um velho deve casar"; o status é de conjectura se sobre a causa questiona-se a necessidade de casar-se. Entender as questões é fundamental para construir um discurso, pois elas são a base de uma investigação. Como já vimos, o primeiro passo para a invenção é identificar o tipo de discurso; o seguinte é trabalhar o status que convenha à causa.

Para concluir o capítulo 5, Quintiliano define "causa". Primeiro, a opinião de Apolodoro: "causa é um caso que está voltado em todos os aspectos para uma questão" (causa est negotium omnibus suis partibus spectans ad quaestionem) ou "a causa é um caso cujo fim é a controvérsia" (causa est negotium cuius finis est controversia). O caso, segundo Apolodoro (ou seu tradutor latino, Válgio), "é uma combinação de pessoas, lugares, épocas, motivos, meios, incidentes, ações, instrumentos, falas, evidências escritas e não escritas" (3.5.17. negotium est congregatio personarum, locorum, temporum, causarum, modorum, casuum, factorum, instrumentorum, sermonum, scriptorum, et non scriptorum). Sendo assim, Quintiliano propõe "causa" para hipótese e "caso" para perístase, que em outra passagem 15 ele traduziu como "circunstância", e conclui o capítulo, citando o tratado Topica de Cícero: "uma causa se reconhece em pessoas, lugares, épocas, ações e circunstâncias

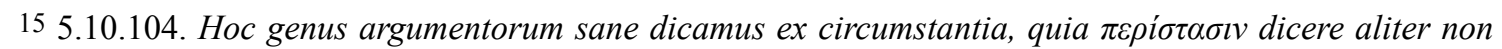
possumus. "Podemos chamar satisfatoriamente este tipo de argumentos 'por circunstância', já que não podemos dizer de outra maneira $\pi \varepsilon \rho i ́ \sigma \tau \alpha \sigma \iota \varsigma . "$ 
determinados, quer em todos ou em sua maioria" (3.5.18. causa certis personis, locis, temporibus, actionibus, negotiis cernitur, aut in omnibus aut in plerisque eorum $)^{16}$.

O décimo capítulo retoma a explicação sobre as causas, dividindo-as em dois gêneros: simples e compostas (ou complexas); a primeira tem somente um status, a segunda, dois ou mais status. Em outras palavras, levando-se em conta que cada questão dá origem a um status, na causa simples há somente uma questão, ou seja, um único ponto que deve ser demonstrado; na causa complexa podem ocorrer duas situações: uma que apresente duas questões ou mais, porém independentes, e outra em que as questões estejam relacionadas entre si, daí Quintiliano mencionar o gênero comparativo. Mas, ainda que nomeie esse terceiro gênero, trata-se de um subgênero da causa complexa, que poderia ainda abarcar a acusação mútua, situação em que acusação e defesa utilizam status diferentes, referentes a quaestiones menos importantes numa determinada causa. Os tipos de causas são esses; retomaremos a classificação das causas mais adiante, quando trataremos dos status). O capítulo 10 é breve e conclui: "Uma vez que estiver claro qual é o gênero de causa, devemos analisar se é possível negar o fato relatado, se ele é defensável, se é possível dar-lhe outro nome, ou se é preciso excluí-lo deste gênero de processo. Daí vêm os status" (3.10.5. Cum apparuerit genus causae, tum intuebimur negeturne factum quod intenditur, an defendatur, an alio nomine appelletur, an a genere actionis repellatur: unde sunt status).

\subsection{Os status}

O sexto capítulo é dedicado à doutrina dos estados de causa. Embora já tenha sido exposto anteriormente nos manuais latinos Rhetorica Rhet.Her.ennium e De Inventione, é na Institutio Oratoria que o sistema de Hermágoras ganha destaque, como ressalta Joachim Adamietz (1966) com relação à teoria dos status:

\footnotetext{
"A apresentação de Quintiliano supera a dos demais não apenas na extensão, mas diferencia-se também, de uma maneira característica, no conteúdo. Enquanto os outros desenvolvem alguma definição e divisão habituais, Quintiliano reúne os estudos da tradição a seu alcance. A essência do status é definida separadamente,
}

16 Cf. Top. 80. 
com opiniões alheias. As discussões mantidas sobre a essência do status, unde ducatur status e an semper faciat qui respondet, não tinham sido ainda mencionadas em textos anteriores que nos chegaram.” (p. 17)

A discussão central sobre os estados de causa divide-se em teorias alheias (3.6.29-62) e a proposição do próprio Quintiliano (3.6.63-90); ambas as partes formam uma grande classificação e resumem a história da teoria dos status. Segundo Adamietz (pp. 17-18), não é possível saber até que ponto Quintiliano apoia-se em outros autores - muito provavelmente, há antecessores que apresentaram suas teorias, mas o resumo da opinião de outros, bem como outras partes de suas obras, é mérito de Quintiliano.

Uma vez que a invenção é o centro do interesse de Quintiliano, é com especial atenção que ele se dedica a essa parte da arte, o que se verifica no cuidado com que o autor introduz o tema, descrevendo a dificuldade de abordar um assunto já tão trabalhado por autoridades gregas e latinas, demonstrando uma preocupação didática em reafirmar uma tradição, da qual muitos outros já trataram.

Joachim Adamietz (1996, p. 16) também avalia que uma visão geral descrevendo a trajetória da arte e listando rétores gregos e latinos - nesse ponto do trabalho foi uma medida calculada, posto que no terceiro livro se inicia a exposição sobre a parte mais importante da teoria retórica na abordagem da Institutio Oratoria.

Definidos questão, estado de causa e gênero de causa, resta ainda, se seguirmos Hermágoras (de acordo com Quintiliano), examinar o que é a questão (quaestio), o motivo (ratio), o ponto a julgar (iudicatio) e o ponto central (continens), também denominado fundamento (fundamentum). Esses pontos constituem o conteúdo do último capítulo do terceiro livro da Institutio Oratoria.

Em retórica, entende-se uma questão "como todo assunto sobre o qual se pode discutir com credibilidade segundo duas ou mais opiniões" (3.11.1. de qua in utramque partem vel in plures dici credibiliter potest). Especificamente no âmbito judicial, questão pode ser considerada "o ponto mais importante sobre o qual versa a causa" (3.11.2. summam illam, in qua causa vertitur) e que dá origem ao status.

As formas de designar "questão" variam. Hermágoras e Apolodoro simplesmente as denominam "questões" (quaestiones), e Teodoro, "pontos gerais" (capita generalia), mas há o consenso de que "uma questão dá origem a outra e 
que se divide em outras espécies" (3.11.3. quaestionem ex quaestione nasci et species

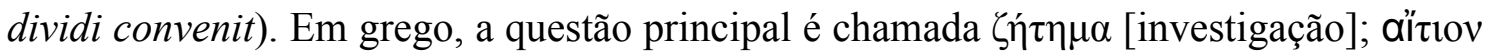
é o motivo, a motivação que nos permite defender o que se sabe que aconteceu; o ponto

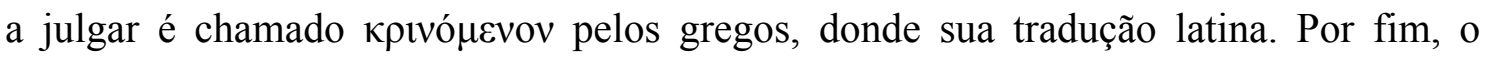
ponto central ou fundamento - em grego ovvézov —, que seria, na definição de Cícero, “o argumento mais eficaz da defesa e o mais adequado para o ponto a julgar" (Inv. 1.19. Firmamentum est firmissima argumentatio defensoris et appositissima ad iudicationem). Essa nomenclatura apresentou muita divergência e mal-entendido entre autores latinos na tradução de termos gregos em latim. Para ilustrar esses termos, Quintiliano exemplifica com o notório caso da morte de Clitemnestra. Assim, temos: a causa — "Orestes matou sua mãe, mas alega que o fez legitimamente"; o status será de qualidade, com a questão da legitimidade da ação; o motivo — "Clitemnestra matou Agamêmnon, pai de Orestes"; o ponto a julgar — "é certo que uma mãe, ainda que criminosa, seja morta pelo seu filho?" 17 . Nesse caso não é dado o último item, o ponto central, que "alguns rétores o consideram o argumento depois do qual nada mais pode ser questionado" (3.11.9. quibusdam id videtur esse post quod nihil quaeritur).

Em se tratando de um status de conjectura, o ponto a julgar encontra-se no mesmo lugar da questão, mas no status de qualidade a questão é "se Orestes matou com legitimidade". Porém, essa questão não é ainda o ponto essencial a julgar, que apareceria nesta outra questão: "ela tinha matado meu pai", "mas não é por isso que deverias ter matado tua mãe"; assim, o ponto a julgar seria "ele poderia ter matado sua mãe?"

Quintiliano relata que alguns autores dividiram os status em dois: um, da questão, e o outro, a julgar. Com o exemplo da morte de Clódio, explica: "Milão matou Clódio legitimamente?”, questão de qualidade; “Clódio armou uma emboscada?”, um ponto a julgar de conjectura. Porém, nesse mesmo exemplo, não estaria "a própria conjectura relacionada com a qualidade?" (3.11.17. ipsa coniectura refertur ad qualitatem?), questiona Quintiliano — porque, se foi uma emboscada, Clódio foi morto com legitimidade; assim, mantendo a questão inicial, a questão reside no ponto a julgar.

${ }^{17}$ Cf. 3.11.4-6. 
Para Quintiliano, outros autores, mais sucintos e sensatos, propuseram três elementos para uma causa: o status, o ponto central (continens) e o ponto a julgar (iudicatio), sendo o ponto central indispensável para impetrar um processo, já que sem ele não há causa. Assim, segundo essa proposta, as duas motivações — Orestes matar a mãe e Clitemnestra matar Agamêmnon - são abarcadas em um único processo, levando em conta que o status e o ponto a julgar sempre coincidem.

Além desses exemplos aqui resumidos, Quintiliano expõe alguns mais e ainda menciona as contradições sobre esses elementos, que encontrou nas obras de Cícero. Por fim, sugere que se deixem de lado esses excessos de nomenclatura e divisões, que ele classifica como "detalhismo afetado" (3.11.21. minutas rerum particulas), exposto apenas com a intenção de não parecer descuidado na sua investigação da matéria.

3.11.24. Neque est fere quisquam, modo non stultus atque ab omni prorsus usu dicendi remotus, quin sciat et quid litem faciat (quod ab illis causa vel continens dicitur), et quae sit inter litigantes quaestio, et de quo iudicari oporteat, quae omnia idem sunt. Nam et de eo quaestio est quod in controversiam venit, et de eo iudicatur de quo quaestio est.

"Não existe praticamente ninguém, desde que não se trate de uma pessoa estúpida e completamente alheia à prática da oratória, que não saiba o que ocasiona um litígio (definido por aqueles autores como causa ou ponto central), qual é a questão entre os litigantes, e sobre o que cabe julgar. Tudo isso é a mesma coisa: não apenas a questão está relacionada àquilo que entra em controvérsia, mas também julga-se aquilo de que trata a questão.”

Para o mestre e para o aprendiz é muito mais importante um método enxuto, sem divisões insignificantes; quem é capaz de identificar uma controvérsia e o que a parte contrária quer, é claro que, tomando em consideração primeiro seu objeto, conhecerá bem esses pontos.

Ainda a respeito da questão, do ponto central e do ponto a julgar, Quintiliano menciona a escola de Teodoro, que relaciona tudo a pontos capitais. Daí se pode deduzir que há a questão principal (como um status), tudo o que se relaciona a essa questão principal e, por fim, a proposição com a confirmação, como sendo o "ponto essencial do assunto". Conclusão: "tudo aquilo que deve ser comprovado será um ponto capital, mas de maior ou menor importância" (3.11.27. in universum autem quidquid probandum est 
erit caput, sed id maius aut minus). Retornaremos a essas subestruturas da teoria dos status no capítulo 3 desta tese, na passagem em que examinaremos como encontrar o estado de causa.

Neste primeiro capítulo da tese quisemos fazer um panorama da matéria exposta no livro 3 da Institutio Oratoria. Expusemos pontos que nos pareceram relevantes para entender a concepção de inventio em Quintiliano e que são a base para explicar a classificação dos gêneros do discurso e a teoria dos estados de causa, principal matéria desse livro e o centro de nossa análise. 


\section{Capítulo 2}

A classificação dos gêneros de causa na Institutio Oratoria

À primeira vista, a exposição sobre os gêneros de causa feita por Quintiliano pode parecer confusa ao leitor. Ele começa questionando se são apenas três os gêneros, fala da tripartição da matéria retórica, atribuindo-a a Aristóteles, e explica que outros autores o seguiram por sua autoridade; menciona, então, "alguns autores gregos", Cícero e "a maior autoridade de nossos dias" (sem citar o nome) que criticaram essa antiga divisão, pois "restringiram a um campo tão limitado um material tão vasto"18. Embora inicialmente pareça que irá seguir outro caminho, Quintiliano adere à antiga concepção e apresenta suas razões para dividir os gêneros de causa em demonstrativo, deliberativo e judicial. Na sequência, ele apresenta as opiniões de Anaxímenes ${ }^{19}$, Platão e Isócrates. Por fim, fala de sua própria metodologia e conclui o capítulo 4 do livro 3 da Institutio, explicando que não irá atribuir nenhum assunto específico a cada tipo de discurso.

Para nossa análise da classificação dos gêneros de causa na Institutio Oratoria vamos examinar a teoria em Aristóteles (Retórica), Anaxímenes (Retórica a Alexandre), Isócrates (Discursos) e Cícero (Da Invenção, Partições Oratórias, Orator, Do Orador), autores e obras que, em alguma medida, nortearam o trabalho de Quintiliano neste tema.

\subsection{Os três gêneros de causa em Aristóteles}

A divisão da matéria retórica em três gêneros de causa ou três tipos de discurso oratório — judicial, deliberativo e epidítico — é apresentada na Retórica ${ }^{20}$ de

183.4 .4

19 Quintiliano atribui a Anaxímenes de Lâmpsaco a Retórica a Alexandre. Adotaremos seu ponto de vista em nossa análise, cientes de que não há consenso entre estudiosos a propósito da autoria desse tratado.

${ }^{20}$ Aristóteles, $R h .1358 \mathrm{~b} 7-15$. 
Aristóteles. Provavelmente essa tripartição não é originalmente aristotélica, mas trata-se da referência mais antiga dessa classificação que nos chegou ${ }^{21}$.

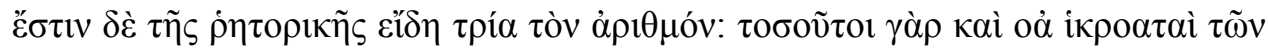

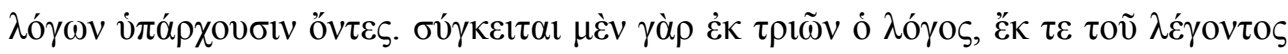

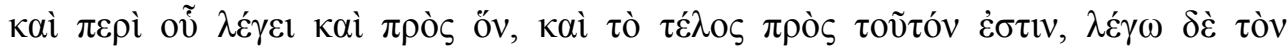

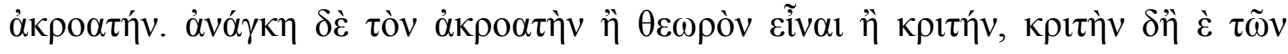

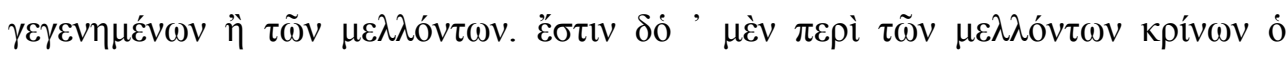

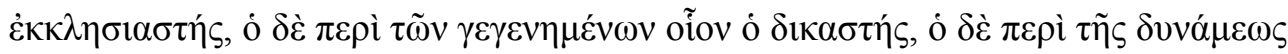

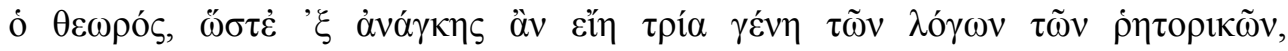

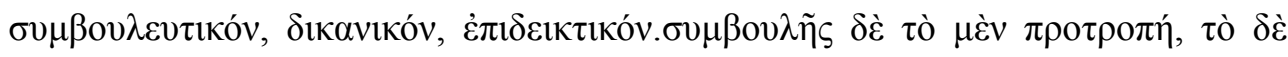

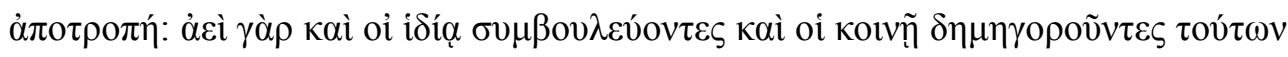

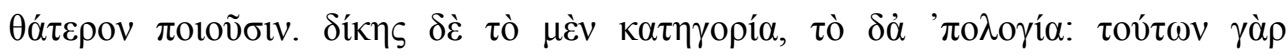

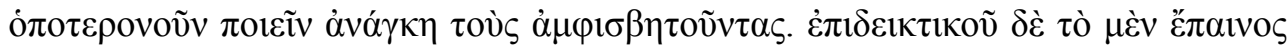

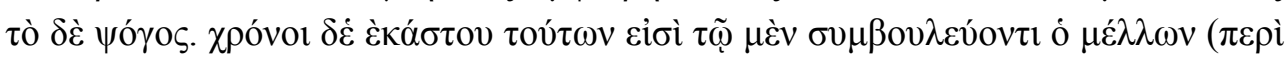

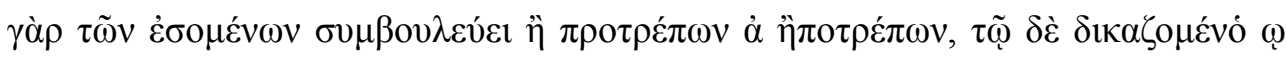

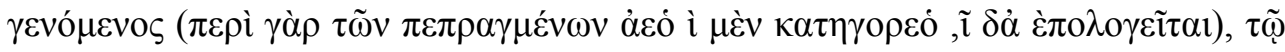

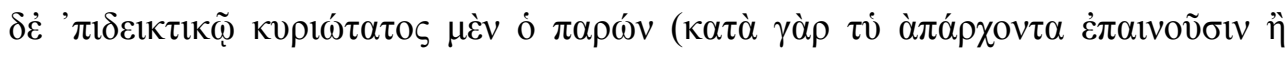

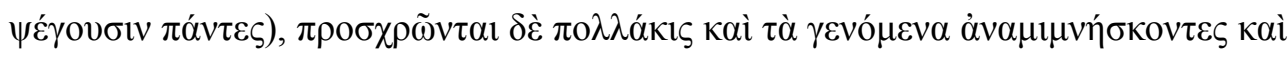

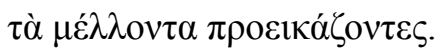

“As espécies de retórica são três em número; pois outras tantas são as classes de ouvintes dos discursos. Com efeito, o discurso comporta três elementos: o orador, o assunto de que fala, e o ouvinte; [1358b] e o fim do discurso refere-se a este último, isto é, ao ouvinte. Ora, é necessário que o ouvinte ou seja espectador ou juiz, e que um juiz se pronuncie ou sobre o passado ou sobre o futuro. $\mathrm{O}$ que se pronuncia sobre o futuro é, por exemplo, um membro da assembleia; o que se pronuncia sobre o passado é o juiz; o espectador, por seu turno, pronuncia-se sobre o talento do orador. De sorte que é necessário que existam três gêneros de discursos retóricos: o deliberativo ${ }^{22}$, o judicial ${ }^{23}$ e o epidíctico ${ }^{24}$.

Numa deliberação temos tanto o conselho como a dissuasão; pois tanto os que aconselham em particular como os que falam em público fazem sempre uma dessas duas coisas. Num processo judicial temos tanto a acusação como a defesa, pois é necessário que os que pleiteiam façam uma destas coisas. No gênero epidíctico temos tanto o elogio como a censura. Os tempos de cada um destes são: para o que delibera, o futuro, pois aconselha sobre eventos futuros, quer persuadindo, quer dissuadindo; para o que julga, o passado, pois é sempre sobre actos acontecidos que um acusa e outro defende; para o gênero epidíctico o tempo principal é o presente, visto que todos louvam ou censuram eventos actuais,

\footnotetext{
21 Cf. Hesk (2009, p. 145); Hinks (1936, p.172).

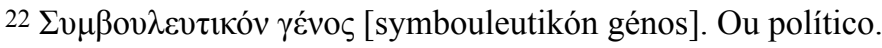

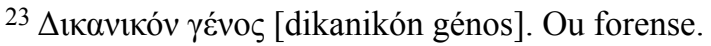

24 'E $\pi \imath \varepsilon \varepsilon \imath \tau \imath \kappa o ́ v ~ \gamma \varepsilon ́ v o \varsigma$ [epideiktikón génos]. Ou demonstrativo.
} 
embora também muitas vezes argumentem evocando o passado e conjecturando sobre o presente." 25

D. A. G. Hinks vê uma aparente "anomalia" na classificação adotada por Aristóteles: por um lado, são três tipos de discurso, cada um com sua finalidade

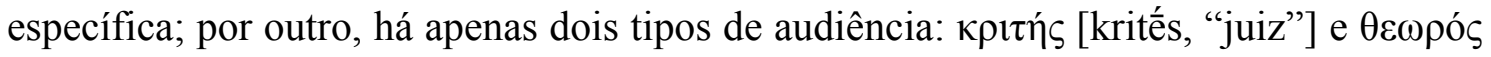
[theōrós; "espectador”]. Mas Hinks explica que a diferença entre o número de discursos e o de gêneros de audiência seria uma discrepância se fossem levados em consideração somente os três gêneros de oratória, o que reforçaria a ideia de que Aristóteles teria simplesmente adotado a teoria retórica recorrente de sua época. Porém, como está demonstrado no Quadro 1, o que está em questão é o papel do ouvinte: ele é árbitro ou espectador - árbitro do passado (julgamento) e do futuro (deliberação), e espectador da arte. A oratória epidítica não tem que provar nada, mas — esclarece Hinks — "o orador deverá prestar atenção à sua arte, com a qual ele espera impressionar a partir de suas ideias os ouvintes, que não serão árbitros, mas críticos, mesmo que inconscientemente, da arte que ele exercita. Se os ouvintes ficarem impressionados com o discurso, o orador alcançou seu objetivo" 26 .

Quadro 1 - Classificação de Aristóteles segundo a audiência e o tempo

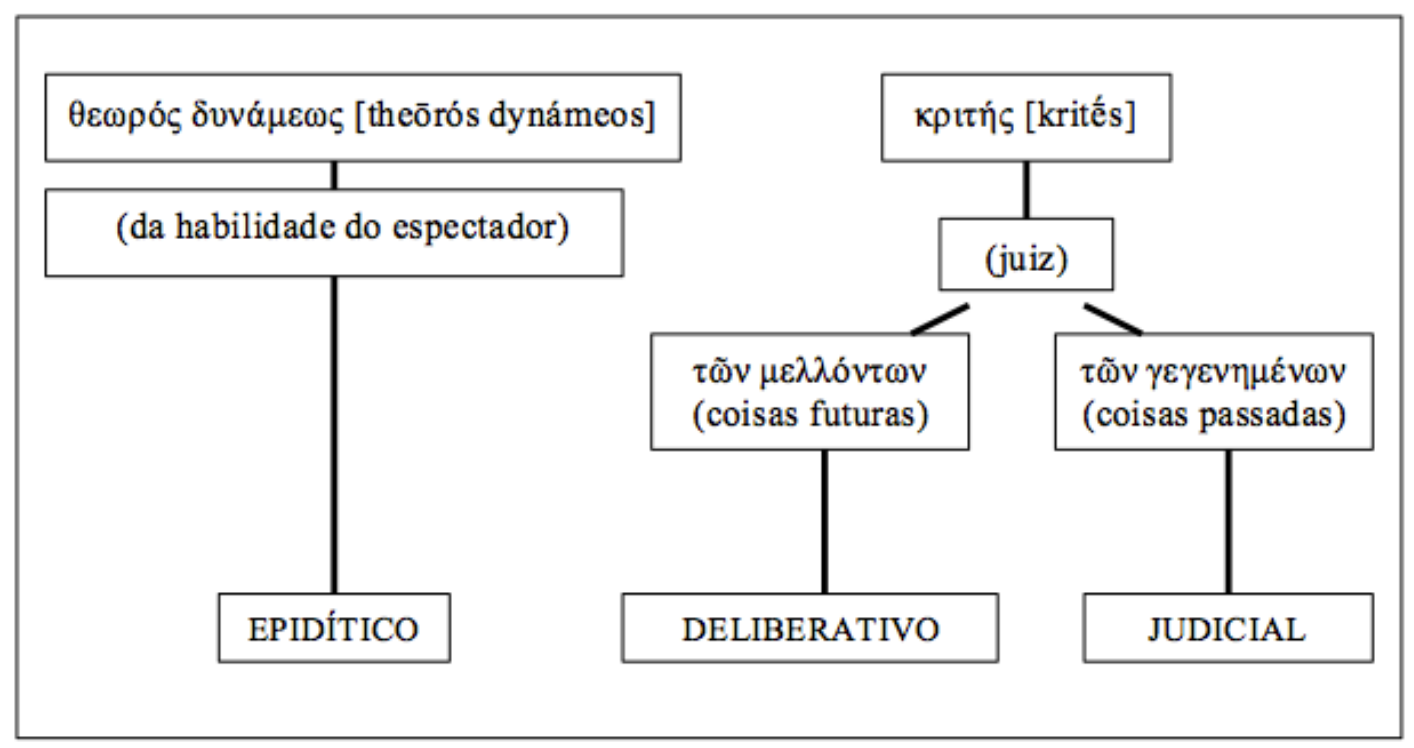

25Aristóteles, Rh. 1.3 (Tradução de Manuel Alexandre Júnior. Imprensa Nacional Casa da Moeda, Lisboa, 1998).

26 D. A. G. Hinks, (1936, p.174). 
Hinks vê ainda uma "debilidade" nessa classificação, que teria levado a divergências os autores que a seguiram: a maioria deles não encontrou dificuldade em adotar os dois primeiros tipos de discurso (judicial e deliberativo), mas ocorreu muita dissensão no tratamento dado ao terceiro tipo (epidítico). A razão disso foi que alguns rétores levaram em conta apenas o assunto/matéria (elogio e vitupério), e não fizeram distinção entre a oratória epidítica, por um lado, e a forense e deliberativa, por outro. ${ }^{27}$

Cristina Pepe (2013, p. 123 ss.) propõe analisar a caracterização dos gêneros do discurso na Retórica, vinculando-a à especulação em outros textos de Aristóteles, pois a Retórica segue uma orientação dual, ou seja, é uma "elaboração teórica de um modelo científico de filosofia retórica" e, ao mesmo tempo, uma "descrição empírica de técnicas discursivas" (p. 126). Segundo a estudiosa, o manual aristotélico pareceria bem mais um projeto que sofreu modificações ao longo de sua elaboração, com o objetivo de codificar a persuasão, proporcionando recursos para explicar como se constrói a persuasão, mas não um fim para a eloquência (ibid.).

Segundo Aristóteles, o processo retórico compõe-se de três elementos: o orador, o ouvinte e o assunto do discurso, tripartição também aplicada para classificar as provas técnicas em ethos, pathos e $\log _{0 s^{28}}{ }^{2}$. A audiência é um elemento determinante na formulação dos três gêneros de retórica: as "espécies de retórica" são três porque são três as espécies de ouvintes: o que julga sobre o passado (judicial), sobre o futuro (deliberativo) e aquele que julga sobre o presente (epidítico). Além da temporalidade, a função comunicativa e a finalidade são também justificativas para o número de gêneros. A função comunicativa define, distintamente, os discursos nas assembleias e os discursos nos tribunais. O objetivo do discurso, por sua vez, influi na abordagem: quando damos um conselho, falamos do que é útil e nocivo; em um julgamento tratamos do justo e do injusto; em discursos de exibição mencionamos o que é honroso e desonroso.

Em Aristóteles há uma certa autonomia de cada gênero. Ao orador é imprescindível conhecer as características de cada tipo de discurso para empregar os argumentos mais adequados a cada situação, bem como um tipo particular de elocução.

\footnotetext{
${ }^{27}$ Cf. Hinks (1936, p.174); Rhet.Her. 1.2; Cícero, Inv. 1,7; De Orat. 1.141; 3.109; Top. 91. ${ }^{28}$ Rh.1356a1-4.
} 
Além disso, cada gênero tem uma forma argumentativa característica — por exemplo, a ampliação, no epidítico; os exemplos, no deliberativo; os entimemas, no judicial (PEPE, 2013, pp. 134-7).

Pepe identifica a tripartição conceitual dos discursos em Aristóteles como derivada da prática oratória nos contextos e condições políticas de Atenas nos séculos 5 e 4 a.C., lembrando que "o direito de participar numa assembleia e atuar como juiz em um tribunal estão incluídos entre as qualificações necessárias para definir um cidadão" (PEPE, 2013, p. 138)29.

A vida política, no entanto, não explica a introdução do gênero epidítico na prática da eloquência. A criação desse terceiro gênero como um gênero independente é vista como uma das grandes inovações de Aristóteles ${ }^{30}$. Cristina Pepe considera que o terceiro gênero oratório é provavelmente o "resultado de uma elaboração longa e complexa" (p. 145), como se fosse um acréscimo posterior à Retórica. Nos dois primeiros capítulos do livro 1 da Retórica não há menção a esse gênero, que aparece por primeira vez no terceiro capítulo desse livro, descrito dentro dos mesmos parâmetros dos outros dois gêneros, mas sua posição no esquema (como mostramos acima) é assimétrica. De forma semelhante, no início do segundo livro, Aristóteles parece negligenciar o epidítico, dedicando maior atenção aos gêneros deliberativo e judicial ${ }^{31}$, o que poderia ser entendido como indício de um acréscimo posterior à teoria.

Quintiliano, por seu turno, afirma reconhecer autores que dividiram a oratória em três tipos porque três são os tipos de ouvintes - ao primeiro caberia o deleite ( $\mathrm{ad}$ delectationem) do discurso; ao segundo, um conselho (consilium); o terceiro julgaria uma causa (de causis iudicet) —, mas identifica a dificuldade dessa sistematização, pois, ao considerar a audiência como a finalidade do discurso, poderia limitar o campo da retórica e excluir outros contextos de discursos. Em seguida ele afirma que a efetividade de um discurso pode estar dentro ou fora de um tribunal e que se delibera

\footnotetext{
29 Cf. Aristóteles. Política, 1275a22-26.

30 Segundo Cristina Pepe (2013, p. 144), estudiosos de retórica são unânimes em atribuir a introdução do gênero epidítico a Aristóteles. Em nota ad locum, Buchheit (1960); Pernot (1993, pp. 25-30); Brunschwig (1994, pp. 90-91) e Rapp (2002). Também entre os antigos o gênero epidítico está associado a Aristóteles: cf. especialmente Cic. De Orat. 2.43.

31 Ao anunciar o tratamento do ethos e do pathos, Aristóteles leva em consideração apenas a deliberação e os processos judiciais. Ver $R h$. 1377b20-137a.
} 
sobre coisas futuras e se louva sobre coisas passadas, propondo um novo caminho para seguir o esquema aristotélico, conforme demonstrado no Quadro 2, a seguir:

Quadro 2 - Classificação de Quintiliano de acordo com o lugar

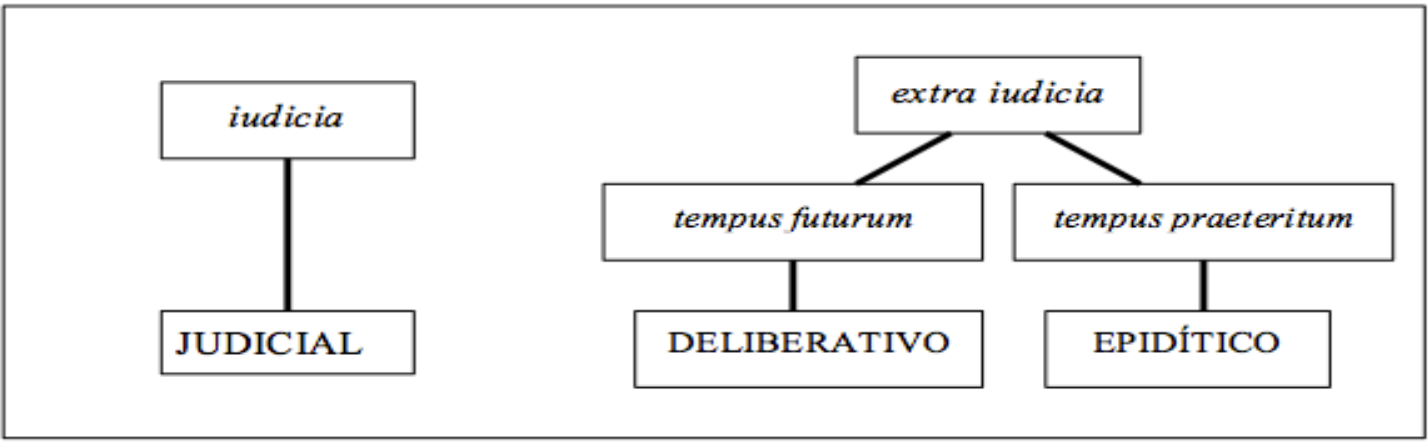

Ampliando o terreno do gênero epidítico, que ultrapassa os limites da laus e vituperatio, para ser mais preciso, é elaborada uma segunda sistematização, dividindo em dois os tipos de matéria oratória, coisas certas e coisas incertas, atribuindo a cada um o correspondente gênero discursivo, como representado no Quadro 3:

Quadro 3 - Classificação de Quintiliano de acordo com o assunto

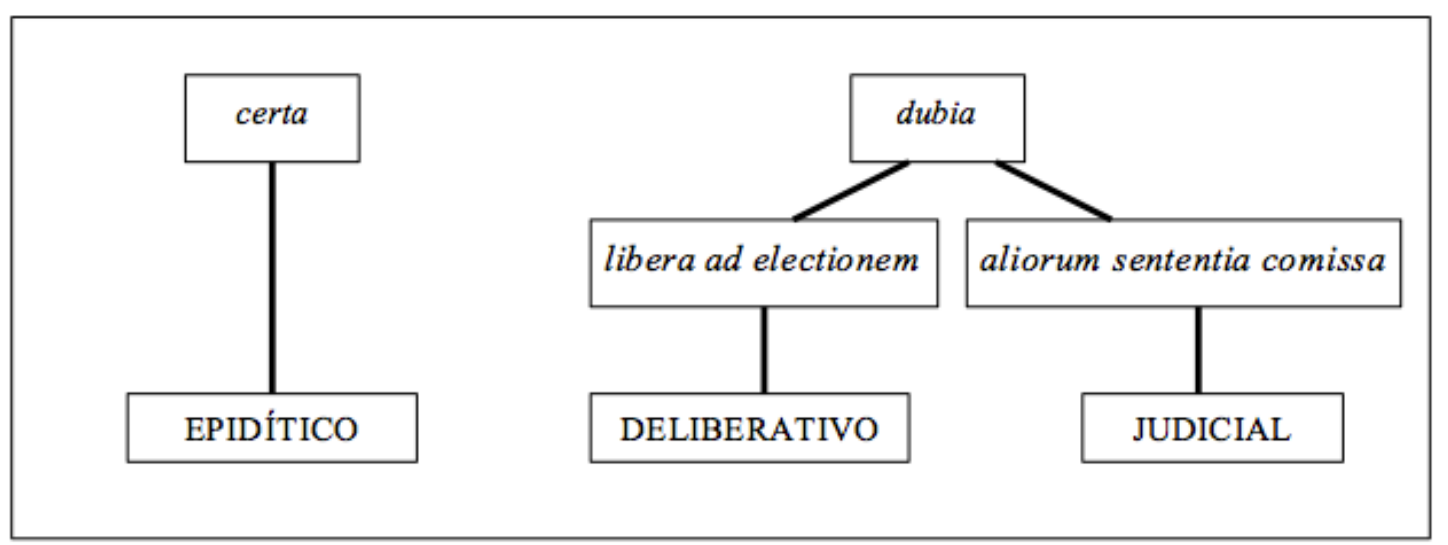

Ainda que a teoria aristotélica possa ter servido de referência para a classificação dos gêneros de causa na Institutio, Quintiliano a remodelou por reconhecer que essa tripartição limitava o terreno da oratória.

Não é possível afirmar se Quintiliano consultou fontes diretas ou não, mas as obras de Aristóteles eram um ponto de partida para qualquer estudo sério já no século 1 a.C. Além disso, era prática comum apresentar teorias endossadas por antigas 
autoridades, e Aristóteles é uma delas, fator que contribuiu para o resgate de seus escritos $^{32}$. Especialmente no livro 3 da Institutio Oratoria, Aristóteles é mencionado com frequência, como se fosse uma retomada da tradição aristotélica, provável influência de Cícero.

\subsection{A classificação dos gêneros em Anaxímenes}

Segundo Quintiliano, Anaxímenes dividiu a matéria oratória em dois grandes gêneros, subdivididos em sete espécies. No entanto, não há consenso quanto à classificação dos gêneros que consta na Retórica a Alexandre, tratado de retórica do século 4 a.C., atribuído a Anaxímenes de Lâmpsaco33 (embora uma carta em forma de prefácio, dirigida a Alexandre, o Grande, cuja autoria foi atribuída a Aristóteles, tenha sido posteriormente acrescida à Retórica a Alexandre).

A versão do tratado que nos foi transmitida começa com $\tau$ pía $\gamma \varepsilon ́ v \eta \tau \hat{\omega} v$

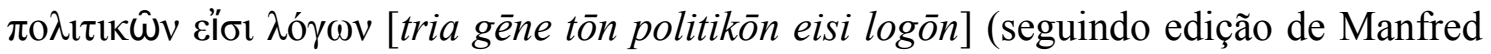

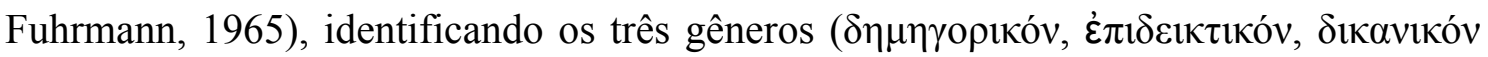
— dèmōgorikon, epideiktikon, dikanikon), de forma semelhante à que faz Aristóteles ${ }^{34}$. Porém, há editores e estudiosos que consideram apenas dois gêneros: o concional e o forense. Além disso, Fuhrmann ${ }^{35}$ alega que a Rhetorica ad Alexandrum, sob o nome de Anaxímenes, originalmente começava com as sete espécies (eide), não com os três gêneros.

O comentador Leonhard Spengel ${ }^{36}$, por sua vez, considerou a hipótese de que o acréscimo da carta ao tratado, com suposta autoria de Aristóteles, ocorreu numa época

\footnotetext{
32 Falcon, A. (ed.). “Aristotelianism in the First Century B.C.”. In: Brill's Companion to the Reception of Aristotle in Antiquity. Boston/Leiden: Brill, 2016, pp.101-109.

33 O primeiro a atribuir a Retórica a Alexandre a Anaxímenes foi Petrus Victorius (1499-1585), escolástico, comentarista de Aristóteles, mas Buchheit (1960, pp.189-198 e 205-207) posiciona-se contra a autoria de Anaxímenes.

34 Aristóteles emprega o termo $\sigma 0 \mu \beta 0 v \lambda \varepsilon v \tau \iota \kappa o ́ \varsigma$ para “deliberativo", com referência apenas a discursos proferidos na assembleia ou conselhos, cujas decisões afetavam toda a pólis.

35 M. Fuhrmann. Anaximenis Ars Rhetorica. Leipzig, 1966.

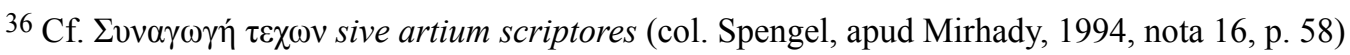


posterior à de Quintiliano e anterior à de Siriano — ou seja, entre os séculos 2 e 5 d.C.

- e que os copistas, acreditando ser uma obra aristotélica, corrigiram o texto, acrescentando um terceiro gênero de causa.

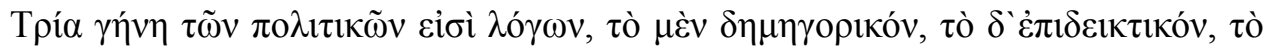

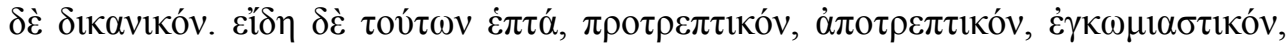

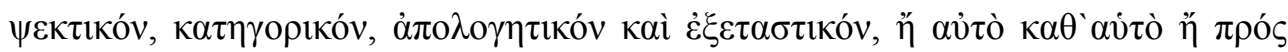

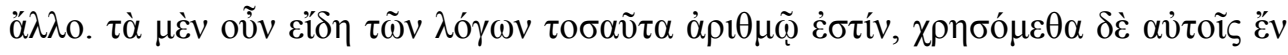

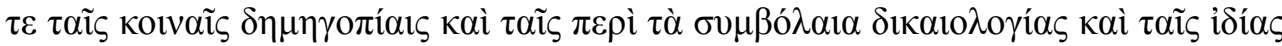

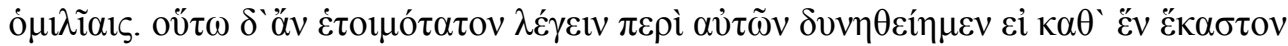

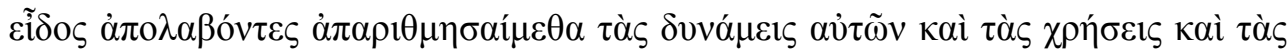
$\tau \alpha \dot{\xi} \xi \varepsilon 1 \zeta$.

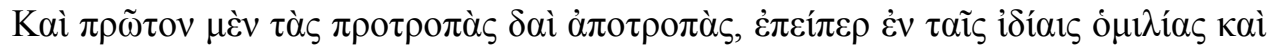

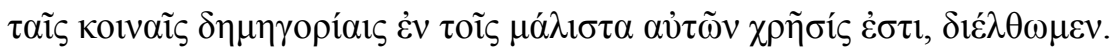

"Os discursos públicos pertencem a três gêneros, quais sejam, o deliberativo (parlamentar), o epidíctico (cerimonial) e o forense. Estes subdividem-se em sete espécies, que são empregadas na persuasão, na dissuasão, no louvor, na vituperação, na acusação, na defesa e na investigação - isoladamente ou em relação a outra espécie. Esse elenco enumera as espécies em que estão enquadrados os discursos públicos e as utilizaremos nos debates parlamentares, na argumentação de processos legais envolvendo contratos e na comunicação das relações privadas. Nós as discutiremos mais convenientemente se tomarmos cada uma à parte e indicarmos suas qualidades, seus usos e sua disposição.

Iniciemos tratando da persuasão e da dissuasão, já que estão entre as formas mais

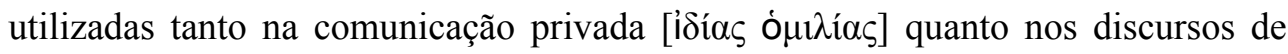
tipo deliberativo." 37

O sistema da Retórica a Alexandre aparentemente se assemelha ao da Retórica de Aristóteles: constam os três gêneros de discurso e suas subdivisões, às quais são

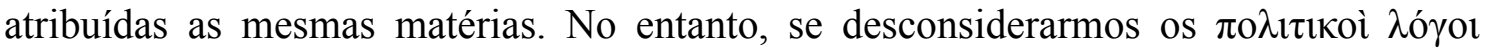

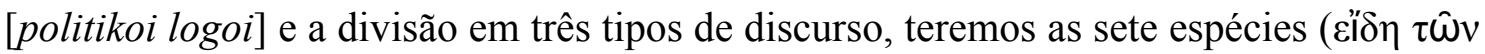
$\lambda$ ó $\omega \omega v$ - eidē tōn logōn) como divisões independentes que, na prática, abrangeriam um extenso campo, servindo a discursos políticos e não políticos, públicos e privados.

Seria possível ainda conceber as espécies, com exceção da sétima, como pares complementares, que definiriam os três tipos de oratória. A base da teoria atribuída a Anaxímenes se apoia sobre essas sete espécies, de acordo com tipos de discursos usados

\footnotetext{
${ }^{37} R h . A l$. 1.1. Utilizamos a tradução em português de Edson Bini (São Paulo, Edipro, 2012), adaptando-a, quando julgamos necessário.
} 
na prática. Segundo Hinks, essa divisão retórica é mais empírica, comparada com a de Aristóteles, que seria analítica. Cristina Pepe $(2013,85)$ enfatiza que, apesar das afinidades, há uma diferença significativa entre a Retórica de Aristóteles e a Retórica a Alexandre, relacionada à qualidade e ao objetivo das duas obras. Enquanto a primeira deve ser analisada sob a ótica da filosofia aristotélica, por se tratar de uma ampla estrutura conceitual inserida em um contexto que envolve política, dialética, ética e antropologia, o tratado atribuído a Anaxímenes é sobretudo um manual prático, em que se reconhece o pragmatismo de um rétor profissional e a influência do relativismo cético dos sofistas.

Anaxímenes causou aparente confusão ao tentar inserir toda a oratória nos discursos públicos, confusão essa que foi solucionada no desenrolar da teoria, levando em conta as espécies de discurso, sem delimitação de campo de atuação para cada uma delas $^{38}$, como mais adiante explica o autor:

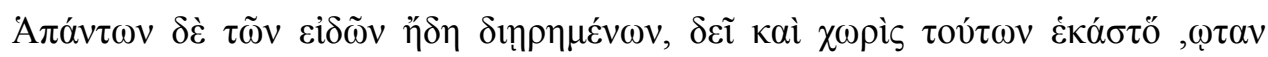

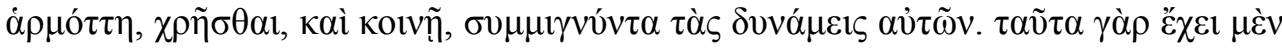

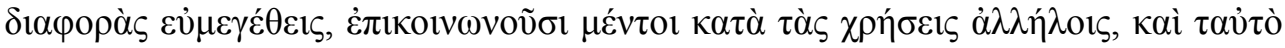

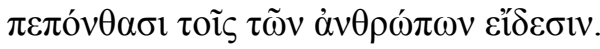

"Estão assim distinguidas todas as espécies de oratória. Devem ser empregadas separadamente (quando apropriado) e conjuntamente combinando-se suas qualidades; assim deve ser porque, embora apresentem enormes diferenças entre si, na sua aplicação prática mostram-se como tendo muito em comum." 39

Pepe (2013) entende que "na ausência de uma definição de retórica, genē e eide (gêneros e espécies) constituem a estrutura da technē, definindo sua extensão e seu campo de investigação" (p. 87). Essa distinção teria um significado relevante em termos didáticos, porque cumpriria a função preliminar de um manual, ou seja, "a divisão clara da matéria e da forma, providenciando instruções para o exercício prático da arte" (id.).

Cristina Pepe, então, identifica duas modalidades de divisão dos discursos na Retórica a Alexandre: uma no nível do genos e outra no nível do eidos. A classificação do discurso segundo o gênero definiria a base do contexto, ou seja, o dikanikós, o

\footnotetext{
38 Hinks (1936, pp. 171-2).

${ }^{39}$ Rh. Al. 5.31-35.
} 
discurso no fórum; dēmēgorikós, discurso na assembleia popular; uma epideixis, uma demonstração expositiva, que proporciona um discurso epideiktikós. As subdivisões dos gene, isto é, no nível do eidos, identificam os tipos de logos: exortação, dissuasão, louvor, vitupério, acusação, defesa e investigação.

Na concepção de David Mirhady (1994), os gêneros na Retórica a Alexandre desempenhariam um papel menor, já que a ênfase está nas espécies de discursos. Embora diferentes entre si, podem ser usadas de forma combinada entre elas. Os critérios de distinção entre as espécies têm relação com as formas de argumentação (amplificação ou provas) e com o lugar (se o discurso será proferido numa assembleia ou num tribunal). É no tratamento dado às espécies que a Retórica a Alexandre se aproxima da Retórica de Aristóteles 40 . Por exemplo, com relação ao encômio e à invectiva, Anaxímenes afirma: "De fato, em discursos pertencentes a este tipo, via de regra não discorremos na disputa de um caso, mas com o objetivo de exibição"41.

Mirhady é um dos estudiosos que atribuem a autoria da Retórica a Alexandre a Anaxímenes, apresentando evidências de uma relação entre a obra e o autor. E embora Quintiliano seja o único a fazer uma conexão direta, não se deve minimizar o fato de que Anaxímenes foi professor de Alexandre e também autor de tratados de retórica. Com base no testemunho de Quintiliano ${ }^{42}$, Mirhady defende a ideia de que Anaxímenes propôs somente dois gêneros de causa. É certo que o epidítico não é um gênero autônomo na Retórica a Alexandre e, além disso, as espécies de discursos de elogio e vitupério têm pouco espaço na teoria de Anaxímenes, quando comparados à atenção conferida às de dissuasão e exortação $0^{43}$. Isso pode ser explicado pelo fato de que não estariam inseridas na classificação dos discursos políticos, que Anaxímenes faz no primeiro capítulo. Hinks vê neste aspecto a possibilidade de o autor haver pensado em

\footnotetext{
40 Cf. Mirhady (1994, p. 62).

41 35.2. Anaxímenes emprega o termo $\varepsilon \pi \imath \delta \varepsilon \dot{\xi} \xi \iota \omega \varsigma$, o mesmo utilizado por Aristóteles para definir o gênero discursivo.

42 3.4.9.

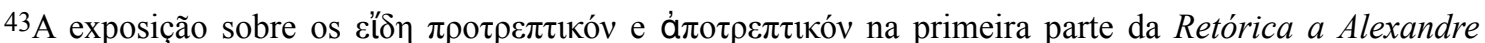
ocupa quatro vezes mais espaço do que os outros dois gêneros, evidenciando o destaque dado à eloquência deliberativa. E na terceira seção do tratado (cap. 29-35), quando são explicadas as partes do discurso, o par exortação/dissuasão vem em primeiro lugar.
} 
considerá-los um outro ramo de oratória, que estaria subordinado à prática forense e política $^{44}$.

A apresentação das espécies de oratória na Retórica a Alexandre começa com o par persuasão/exortação (capítulo 2), seguido de elogio/vitupério (capítulo 3), acusação/ defesa (capítulo 4) e investigação (capítulo 5). A partir do capítulo 6, são apresentados os tópicos mais apropriados a cada tipo de discurso, mas que "são comuns a toda espécie de oratória". Portanto, sem delimitar campos, mas sugerindo as abordagens mais comuns a cada matéria, poderíamos assim esquematizar a teoria segundo Anaxímenes, de acordo com o Quadro 4, a seguir:

Quadro 4 - Retórica a Alexandre I

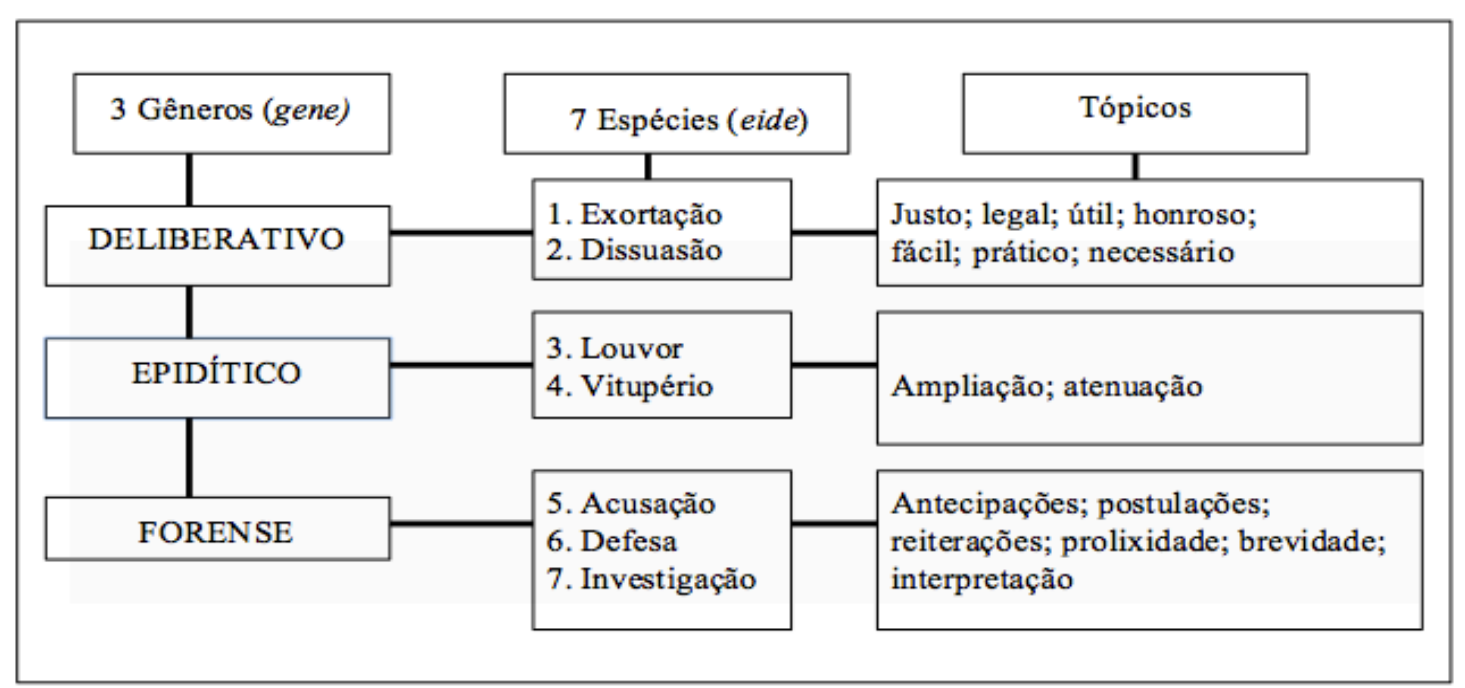

$\mathrm{Na}$ época em que a doutrina retórica era ainda incipiente, era muito comum coexistirem diferentes modos de classificação dos discursos. Mesmo considerando que a base da teoria de Anaxímenes se apoia sobre as espécies, Cristina Pepe (2013, p. 117) propõe uma segunda forma de interpretar a distinção do discurso, mas, ainda assim, compatível com o sistema de gêneros, conforme indicado no Quadro 5:

${ }^{44}$ Hinks (1936, p. 171). 


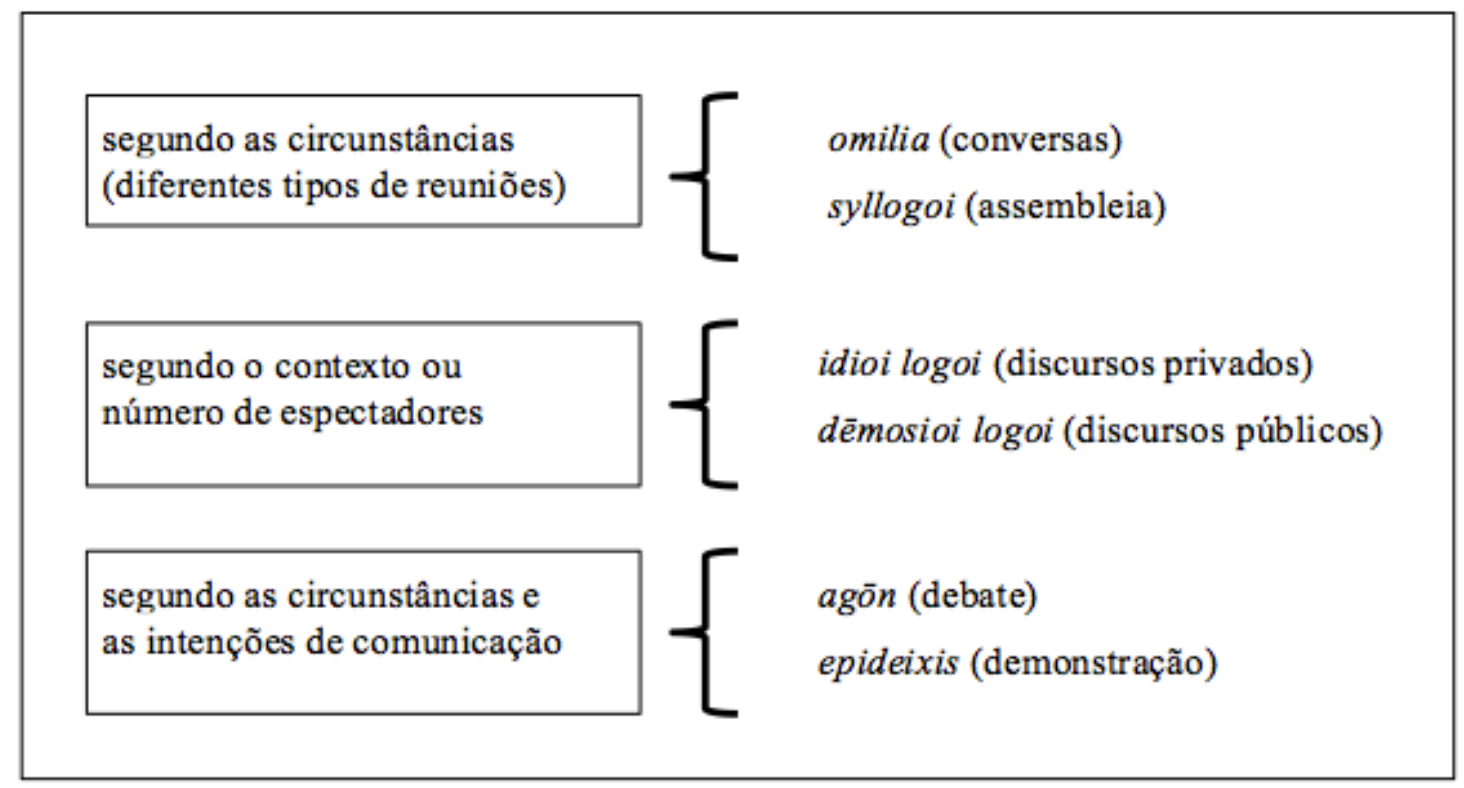

Se comparamos Aristóteles e Anaxímenes, percebemos que a forma como a classificação dos discursos é apresentada pelo primeiro o distancia da forma como é ordenada a teoria na Retórica a Alexandre. Enquanto Aristóteles define premissas específicas para cada um dos três tipos de discurso, admitindo que os oradores em situações judiciais, deliberativas ou demonstrativas tendem a renunciar a todos os pontos na prática, menos àquele que corresponde à proposta de seus discursos ${ }^{45}$, Anaxímenes organiza sua teoria segundo os tópicos e suas aplicações em cada uma das sete espécies, mas com uma seção sobre expedientes comuns a todas. Precisamente essa foi a postura adotada por Quintiliano, que assim encerra a discussão sobre os gêneros de causa:

3.4.16. Ne iis quidem accesserim, qui laudativam materiam honestorum, deliberativam utilium, iudicialem iustorum quaestione contineri putant, celeri magis ac rutunda usi distributione quam vera. Stant enim quodam modo mutuis auxiliis omnia; nam et in laude iustitia utilitasque tractatur et in consiliis honestas, et raro iudicialem inveneris causam in cuius non parte aliquid eorum quae supra diximus reperiatur.

45 Rh. 1358b29-59a6. 


\begin{abstract}
“Eu não concordaria com os que consideram que a matéria do laudativo se restringe ao honroso; a do deliberativo, ao útil; a do judicial, ao justo ${ }^{46}$, fazendo uso de uma divisão mais prematura e bem acabada do que verdadeira ${ }^{47}$. Já que, de uma certa maneira, todos os gêneros se apoiam mutuamente, também no elogio se fala de justiça e utilidade; nas deliberações, de honestidade; e raramente se pode encontrar numa causa judicial que não apresente em alguma de suas partes algo do que acima mencionei."
\end{abstract}

\title{
2.3. Elogio e vitupério em Isócrates
}

A menção a Isócrates no quarto capítulo do livro 3 é breve: "Isócrates", relata Quintiliano, "considerava haver em todo gênero elogio e vitupério" (3.4.11). Cristina Pepe (2013, p. 74) recorda que esse comentário foi tomado como um indicativo para que L. Spengel (1844) e W. Kroll (1940) afirmassem que Isócrates não reconhecia o gênero epidítico como um terceiro gênero. A teoria retórica isocrática, porém, tem uma formulação distinta da tradição manualística, Isócrates não escreveu uma arte (technē), mas propôs uma combinação de teoria e prática, "oferecendo modelos de discursos nos quais os preceitos eram esclarecidos e reforçados com exemplos”, lembra Pepe (2013, p. 61). A classificação dos discursos em Isócrates é determinada com base em aspectos extrínsecos (a quem é direcionado o discurso) e aspectos intrínsecos (conteúdo e forma), ou seja, um discurso deve combinar utilidade pública e elegância formal.

Tomemos o Panegírico como exemplo. Nesse discurso, Isócrates defende a união entre os povos helênicos, sob a hegemonia de Atenas, e a guerra contra os persas. Na primeira parte do discurso é feito o elogio de Atenas (or. 4.21-99); na segunda parte há a exortação para que Atenas desempenhe um papel de destaque em ações futuras, como fruto de seus méritos do passado. Em sua análise desse discurso isocrático, Cristina Pepe o identifica como um exemplo de pallistoi lógoi (“os discursos mais belos"): "condições ideais no ato de comunicação para ambas as partes — audiência e orador, porque combina utilidade com a exibição de habilidade oratória".

\footnotetext{
${ }^{46}$ Aristóteles, Rh. 1. $1358 \mathrm{~b} 20$ ss.; Cícero, Inv. 2.4.

47 Aqui, Quintiliano discorda de Cícero (cf. De Orat. 1.141; Part. 71, 83, 98; Top. 91) que, por sua vez,

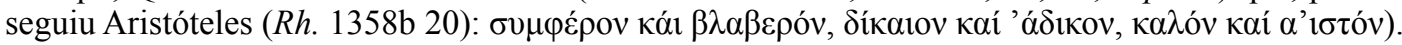




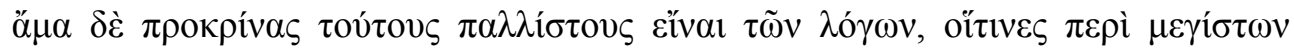

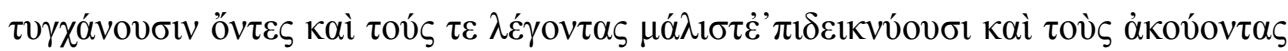
$\pi \lambda \varepsilon \tilde{\sigma} \sigma \tau \omega^{\prime} \varphi \varepsilon \lambda \sigma \tilde{\sigma} \sigma \mathrm{v}$.

"Ao mesmo tempo, julgo que os mais nobres discursos são aqueles que, tratando dos assuntos mais importantes, mais exibem os que falam e são os mais úteis aos que escutam." 48 (Panegírico, Or. 4.11)

No que tange à epideixis (de epideiknymi), é possível entender como uma demonstração do talento do orador ${ }^{49}$, exibição que é uma forma associada à lexis, sem referência a um conteúdo específico. Mas, visto que Isócrates defende a coexistência de vários elementos constitutivos de um discurso, a demonstração isolada não tem valor, é preciso que esteja relacionada a um conteúdo. Apesar disso, no programa de ensino de Isócrates o elogio50 é um tipo de composição autônoma, diferente de outros tipos de discurso $^{51}$. Elogiar em prosa as virtudes de um homem seria tarefa difícil, segundo Isócrates, posto que são os poetas que têm os recursos estilísticos para fazê-lo. Com efeito, o elogio em prosa e o elogio de uma figura histórica52, como no discurso Evágoras (sobre o rei de Salamina, morto em Chipre)53, são duas inovações de Isócrates à disciplina da oratória. Pepe (2013, p. 78) considera que, na prática, essas contribuições estabelecem os fundamentos para o desenvolvimento do elogio individualmente.

Depois de mencionar Isócrates, Quintiliano recomenda seguir as autoridades e passa a falar sobre o gênero laudativo, assim nomeado — explica — pelo seu lado

\footnotetext{
48 Trad. André Rodrigues Bertacchi (cf. bibliog.).

49 Cristina Pepe (2013, p. 72), mencionando carta de Isócrates a Dionísio (circa 367), esclarece que "a $\varepsilon \dot{\varepsilon} i \delta \varepsilon ı \xi 1 \varsigma$ é apropriada para o $\pi \alpha v \eta \gamma v ́ \rho \varepsilon ı$, onde os oradores têm a chance de exibir sua habilidade oratória

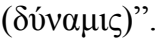

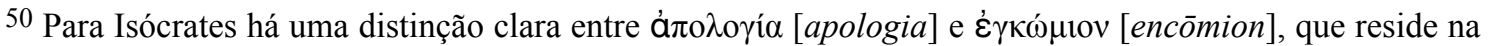
forma de argumentação de um discurso (ideai) e no conteúdo (erga). Enquanto apologia está associada a práticas desonestas de pessoas suspeitas ou culpadas, encōmion tem relação com um comportamento moral adotado por todo homem virtuoso (cf. Pepe, 2013, p. 76).

51 'E $\pi i ́ \delta \varepsilon 1 \xi ı \varsigma$ (“demonstração; exibição”) e $\delta 1 \alpha \pi \rho \alpha ́ \xi \alpha \sigma \theta \alpha \imath$ ("levar a cabo; agir”) são ações que se complementam. Ver Panegírico (or. 4) 17; Pepe (2013, p. 75 ss.).

52 Embora os epitáfios (elogios dos mortos) sejam anteriores a Isócrates, são composições cujos elogios de feitos e valores individuais, são "completamente subservientes ao elogio coletivo dos mortos" (PEPE, 2013, p. 77).

53 Evágoras (or. 9). 
positivo. Mas o nome pode variar: demonstrativo, encomiástico ou epidítico, os dois últimos transcrição direta do grego. Lembramos que o termo غ̇ $\pi i ́ \delta \varepsilon 1 \xi 1 \varsigma$ [epídeixis] abarca em si muitas possibilidades de tradução - quando traduzimos por "apresentação", pode ter uma conotação de virtuosidade e, por consequência, discurso ilusório; se for entendido como "demonstração", pode ter implicações equivocadas de provas lógicas;

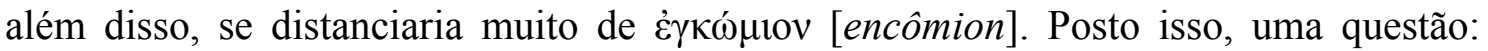
“alguém poderia negar que os panegíricos são discursos epidíticos?" (Quint. 3.4.14. an

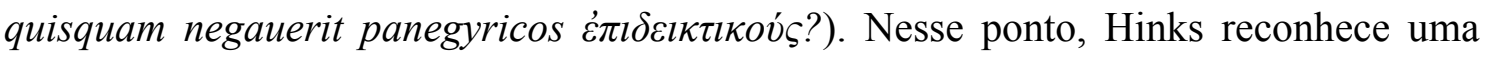

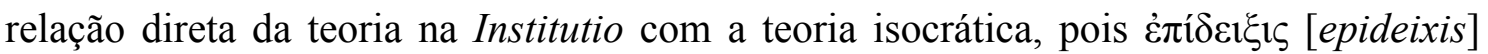
teria o mesmo sentido de panegírico em Isócrates $^{54}$, ou seja, era no panegírico que o

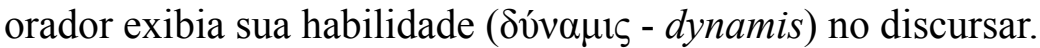

Seguindo a mesma ideia, Jon Hesk avalia que o gênero epidítico permitia aos intelectuais exibirem seus talentos, confirmando a definição do próprio Aristóteles: “o espectador [ouvinte do gênero epidítico], por seu turno, pronuncia-se sobre o talento do orador". Para predecessores e contemporâneos de Aristóteles a prosa pública com os elogios oficiais era uma das muitas formas de retórica epidítica na cidade antiga. $\mathrm{O}$ surgimento do poder autocrático favoreceu o crescimento desse tipo de oratória. Sob o comando de uma autoridade suprema, saber falar em público elogiando o chefe-deestado em ocasiões cerimoniais ganha muita importância55.

Cristina Pepe (2013, p. 140), analisando a relação entre a epideixis ("exibição") e a dynamis ("habilidade") do orador, observa que Isócrates abraçou a concepção sofística do orador, ou seja, aquele que é capaz de discursar (dynámenos légein) e, por isso, é capaz de ensinar essa habilidade a outros.

Assim, a escola de Isócrates - e seus discursos, que provavelmente nunca foram pronunciados — se afasta da tradição aristotélica, da oratória deliberativa e judicial faladas, enfatizando a escrita e leitura de $\dot{\pi} \pi i \delta \varepsilon 1 \xi 1 \varsigma^{56}$. Para Hesk, a história pós-

\footnotetext{
54 Cf. Hinks (1936, p. 173).

55 Hesk (2009, pp. 156-8).

56 Sobre a expressão adequada a cada gênero, no livro III da Retórica (1414a18), diz Aristóteles: "O gênero epidíctico é o mais apropriado ao texto escrito, pois a sua função é ser lido". Isso revelaria uma concepção próxima à de Isócrates; Aristóteles, no entanto, não focou seu trabalho neste gênero.
} 
clássica do gênero epidítico é muito mais isocrática que aristotélica, "é a história de um tipo de discurso que é bastante apropriado para muitos tipos de escrita" 57 .

Além disso, em Isócrates o modelo de discurso apropriado combinava o proveito do orador (que se exibia) com o proveito do ouvinte (que se beneficiava de alguma utilidade no discurso), ou seja, ambas as partes — audiência e orador — eram determinantes para um discurso perfeito. ${ }^{58}$

\subsection{A tripartição dos gêneros de causa em Cícero}

Cícero, em seu tratado de juventude, o Da Invenção, cita a divisão em três gêneros de discurso de Aristóteles e defende que "deve-se tomar como arte e faculdade do orador o que está relacionado com esta matéria tripartida" 59 . Porém, Cícero não faz menção da relação temporal de cada gênero. É nas Partições que a teoria aristotélica é seguida mais de perto:

[10] C.F. Quid habes igitur de causa dicere? C.P. Auditorum eam genere distingui. Nam aut auscultator est modo qui audit aut disceptator, id est, rei sententiaque moderator: ita ut aut delectetur aut statuat aliquid. Statuit autem aut de praeteritis, ut iudex, aut de futuris, ut senatus. Sic tria sunt genera, iudicii, deliberationis, exornationis - quae quia in laudationis maxime confertur, proprium habet iam ex eo nomen.

"10. Cícero filho: O que tem a dizer, então, sobre a causa?

Cícero pai: Que ela se distingue segundo o tipo de ouvinte, pois aquele que ouve, ou é mero espectador ou árbitro, isto é, o determinador do caso e da sentença. Assim, ou se deleita aquele que ouve, ou este toma uma decisão. E toma uma decisão sobre questões passadas, como o juiz, ou sobre futuras, como o Senador. Assim, há três tipos: o julgamento, a deliberação, o adornamento. Este, por se consagrar sobretudo aos louvores, recebe daí a sua denominação particular."

Assim como na Retórica de Aristóteles, nas Partitiones de Cícero o processo de classificar os gêneros começa de acordo com os tipos de ouvintes, distinguindo o espectador daquele que julga e atribuindo-lhes uma determinada experiência - o

\footnotetext{
${ }^{57}$ Hesk (2009, p. 161).

58 Ver Pepe (2013, p. 71 ss).

${ }^{59}$ Inv. 1.7.
} 
deleite ou a deliberação. Então, temos a divisão dos que julgam segundo tempos diferentes - passado e futuro. Mas são três tipos de situações de comunicação, sendo "adornamento" o terceiro, que tem como meta o deleite do ouvinte:

[11] C.F. Quas res sibi proponet in istis tribus generibus orator? C.P. Delectationem in exornatione, in iudicio aut saevitiam aut clementiam iudicis, in suasione autem aut spem aut reformidationem deliberantis.

"11. F: O que o orador estabelece como meta nesses três tipos?

P: O deleite no adornamento; no julgamento, o rigor ou a clemência do juiz; no aconselhamento, a esperança ou o temor de quem delibera." 60

Aqui, nessa divisão dos discursos, estruturalmente, identificamos o modelo aristotélico, mas a proposta de Cícero é, em certa medida, simplificada porque restringe o discurso epidítico ao deleite da audiência, enquanto, para Aristóteles, a habilidade do orador (dynamis) teria um sentido duplo: uma exibição de seu talento oratório e uma demonstração de sua virtude (aretē), trazendo em si a ideia de mostrar o caráter de alguém; ou seja, a dynamis seria a habilidade do laudandus de praticar grandes ações ${ }^{61}$.

Em sua análise, Cristina Pepe parte de duas concepções para dynamis em Aristóteles na Retórica:

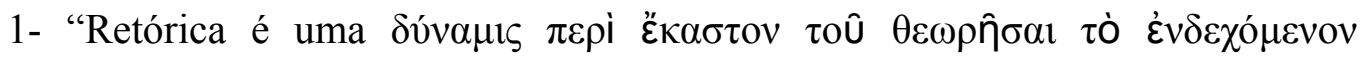
$\pi \imath \theta \alpha$ óv" ("uma habilidade, em cada situação, de encontrar os meios disponíveis de persuasão");

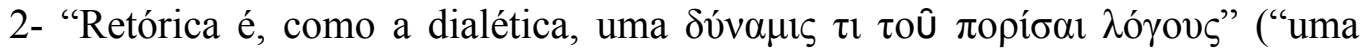
habilidade de fornecer argumentos")62.

As duas exegeses de dynamis estariam relacionadas às duas explicações de Aristóteles para o gênero epidítico:

\footnotetext{
60 Part. 10-11.Tradução de Adriano Scatolin. Em apontamentos de aulas para o curso de pós-graduação "A oratória no fim da república romana". Departamento de Letras Clássicas e Vernáculas - FFLCH/USP, $1^{\circ}$ semestre, 2016.

61 Segundo Pepe (2013, p. 140), essa apreciação aparece por primeira vez em O. Kraus, que entende a dynamis como o objeto de elogio no discurso epidítico, posição seguida também por D. C. Mirhady (1995, pp. 405-409) e, posteriormente, por C. R. Rapp (2002, pp. 256-257).

${ }^{62}$ Rh. 1355b25-6 e 1356a33, respectivamente.
} 


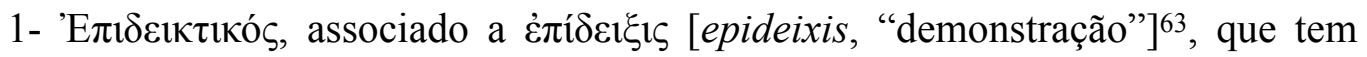

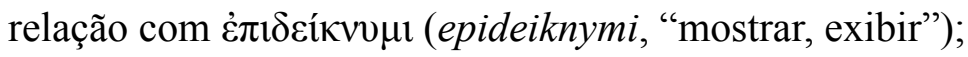

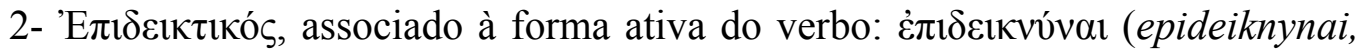
"mostrar, provar o caráter de alguém ou algo").

Pepe recorda que em época posterior a Aristóteles, embora houvesse oscilação entre essas duas interpretações, a concepção mais difundida para o gênero epidítico era a de uma exibição do orador, destinada a comprazer a audiência; como explica Cícero

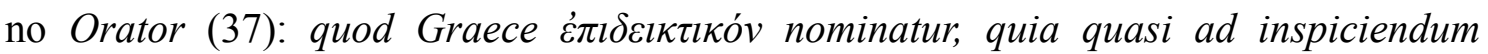
delectationis causa comparatum est ("que é denominado epideiktikón em grego e é produzido para ser executado somente pelo prazer que proporciona”).

Essa posição, no entanto, não se mantém no De Oratore, obra da maturidade. Cícero defende que a habilidade oratória é necessária também em outros campos, ultrapassando os limites dos discursos oratórios e seu conjunto de regras, que determina os três gêneros.

[41] Sequitur igitur, quoniam nobis est hic, de quo loquimur, in foro atque in civium constituendus, ut videamus, quid ei negoti demus cuique eum muneri velimus esse praepositum; nam Crassus heri, cum vos, Catule et Caesar, non adessetis, posuit breviter in artis distributione idem, quod Graeci plerique posuerunt, neque sane quid ipse sentiret, sed quid ab illis diceretur, ostendit: duo prima genera quaestionum esse, in quibus eloquentia versaretur, unum infinitum, alterum certum. [42] Infinitum mihi videbatur id dicere, in quo aliquid generatim quaereretur, hoc modo: expetendane esset eloquentia? Expetendine honores? Certum autem, in quo quid in personis et in constituta re et definita quaereretur cuius modi sunt, quae in foro atque in civium causis disceptationibusque versantur. [43] Ea mihi videntur aut in lite oranda aut in consilio dando esse posita; nam illud tertium, quod et a Crasso tactum est et, ut audio, [ille] ipse Aristoteles, qui haec maxime inlustravit, adiunxit, etiam si opus est, minus est tamen necessarium." "Quidnam?" inquit Catulus; "an laudationes?

[XII] [49] "Quid si, quod saepe summis viris accidit, mandata sint exponenda aut in senatu ab imperatore aut ad imperatorem aut ad regem aut ad populum aliquem a senatu, num quia genere orationis in eius modi causis accuratiore est utendum, idcirco pars etiam haec causarum numeranda videtur aut propriis praeceptis instruenda?" "Minime vero," inquit Catulus; "non enim deerit homini diserto in eius modi rebus facultas ex ceteris rebus et causis comparata."

63 Cristina Pepe (2013, p. 141) ressalta que, no século 4 a.C., o termo tinha como significado-padrão "pronunciamento oratório" 
"41. Segue-se, portanto, já que temos de colocar esse orador de que falamos no fórum e aos olhos dos cidadãos, que devemos entender que atividade the atribuiremos e de que tarefa pretendemos que seja encarregado, (...) Crasso expôs brevemente, na divisão da arte, o mesmo que a maioria dos gregos expõe, e não mostrou em absoluto o que ele próprio pensava, mas o que aqueles diziam: que são dois os principais tipos de questão em torno das quais gira a eloqüência: um, o indefinido, o outro, o definido. 42. Parecia-me querer dizer que indefinido é aquele em que se investiga algo de modo genérico, da seguinte forma: a eloqüência é algo desejável? As honrarias são algo desejável? E que definido, por outro lado, é aquele em que se investiga algo em pessoas e situações estabelecidas e delimitadas; desse tipo são os que giram em torno do fórum e das causas e debates entre cidadãos. 43. Tais tipos parecem residir, ou na exposição dos litígios, ou no aconselhamento; pois aquele terceiro tipo, que foi abordado por Crasso e que, segundo ouvi dizer, o próprio Aristóteles, que trouxe enorme luz a tais temas, acrescentou, ainda que seja útil, é menos necessário. (...)

49. - Ora, se, como não raro acontece aos homens mais eminentes, comunicados tiverem de ser dados, seja no Senado por um comandante, seja a um comandante, a um rei ou a algum povo pelo Senado, você acredita que, pelo fato de ser preciso empregar um tipo de discurso mais acurado em causas do gênero, também esta parte das causas deva ser categorizada ou ensinada com preceitos particulares?

— De modo algum - respondeu Cátulo —, pois, em questões do gênero, não faltará a um homem bem articulado uma capacidade adquirida nos demais assuntos e causas." 64

Essa sistematização que classifica a matéria oratória em coisas certas e coisas incertas, como vimos (Quadro 3, apresentado neste capítulo), foi adotada por Quintiliano, adaptando a tripartição dos discursos à sua proposta. Como já explicamos, as obras ciceronianas foram fontes primárias e prioritárias para a Institutio, mas nosso objetivo aqui é mostrar que, no que tange à classificação dos gêneros de causa, Quintiliano não seguiu Cícero.

O termo "demonstrativo" é empregado com frequência para designar o gênero epidítico, como no De Inventione (2.13), quando Cícero define causa deliberativa da seguinte forma: quae pertineat ad vitae alicuis demonstrationem ("que diz respeito à exibição da vida de alguém”). Contudo, para Quintiliano, demonstrativus, através de elogios e vitupérios, "mostra a natureza de qualquer coisa" (3.4.14). Desse modo, a interpretação de Buchheit (1960, p. 120 ss.) seria, de acordo com Pepe (2013, pp. 142-3), uma terceira solução, segundo a qual dynamis é a habilidade do orador, não

\footnotetext{
${ }^{64}$ De Orat. 2. Tradução Adriano Scatolin (cf. bibliografia).
} 
tanto nas suas capacidades de exibição estilística, como na sua habilidade de mostrar as virtudes da pessoa elogiada.

Friedrich Solmsen salienta que o De Inventione reflete uma tendência de concentrar a teoria oratória quase exclusivamente no gênero judicial. Tendência essa que se desenvolveu na época helenística, particularmente representada por Hermágoras e sua teoria das $\sigma \tau \alpha ́ \sigma \varepsilon ı \varsigma^{65}$.

Por sua vez, D. A. G. Hinks avalia que no período helenístico, uma época sem liberdade política, subsistiu muito mais o gênero judicial (de uso assegurado) e "em

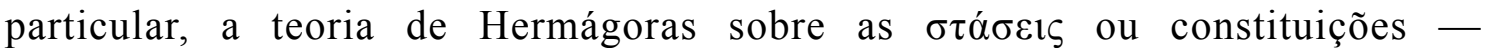
independentemente da teoria de Aristóteles — insere-se no maior detalhamento dos casos judiciais e demonstra que foi planejada sobretudo com a retórica forense em mente"66. No entanto, ainda segundo Hinks, numa época helenística tardia, em circunstâncias de maior liberdade, ocorreu um reavivamento da retórica, havendo um equilíbrio em favor dos outros gêneros de oratória. O Da Invenção representaria essa transformação, que apresenta a teoria dos status com detalhamentos, mas não a relaciona à divisão do assunto em três gêneros. Hinks admite que essa tendência de exclusividade do gênero judicial, "vigorosamente combatida por Cícero nos seus anos de maturidade", nunca chegou a se impor.

\subsection{A divisão dos gêneros oratórios em Quintiliano}

Até este ponto, analisamos como é discutida a tripartição dos discursos no quarto capítulo do livro 3 da Institutio. A partir de agora, mostraremos como Quintiliano trata separadamente cada um dos tria genera causarum, dedicando a cada tipo um capítulo do terceiro livro.

\subsubsection{Gênero epidítico}

\footnotetext{
65 Somsen II (1941, p. 181). Também Mirhady (1994, p. 62).

66 Hinks (1936, p. 176).
} 
Muitas vezes tratado como "o terceiro gênero dos discursos", o epidítico não ocupa esse lugar na Institutio, sendo o primeiro dos três a ser apresentado por Quintiliano, que lhe dedicou o capítulo 7 do terceiro livro. A exposição começa com a referência a Aristóteles, "que separou este gênero de causa da parte prática, isto é

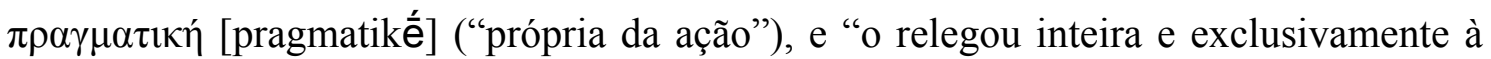
audiência" (3.7.1. totamque ad solos auditores relegasse).

Laurent Pernot (1993, p. 34) ressalta que a relevância da ordem seguida para apresentação dos gêneros somente tem sentido nos tratados em que o epidítico vem em terceiro lugar ${ }^{67}$. Nesse caso, o rótulo de "terceiro gênero" indica sua "situação periférica no campo oratório". Nos manuais centrados no gênero judiciário - Rhetorica Rhet.Her.ennium (1.2), De Inventione (1.7), Partitiones Oratoriae (10, 70), De Oratore (2.43, 340-1), Institutio Oratoria - era comum expor primeiro a oratória demonstrativa.

A principal característica do gênero epidítico é a demonstração, daí o nome “demonstrativo". Demonstração não é prerrogativa exclusiva do gênero epidítico. Não importa o gênero, na retórica todo discurso tem a função de exibir e demonstrar (PERNOT, 1993, p. 37); mais ainda, “a epideixis é mais forma que um conteúdo. O elogio é um dos possíveis conteúdos da epideixis" (id., p. 27). Como vimos acima, o elogio tornou-se uma forma retórica com Isócrates e foi introduzido no sistema de classificação dos gêneros por Aristóteles. No entanto, Pernot (1993, p. 26) relata que a epideixis e a classificação dos gêneros seguiram história separadamente até o momento de sua junção. No século 5 a.C. os sofistas apresentavam discursos sem finalidade prática, isto é, discursos que não envolviam interesses reais, sem incitação a nada. Essa prática era uma epideixis, uma arte dos sofistas.

Quintiliano diz que o nome desse gênero deriva de demonstração, por ser essa sua principal característica (3.7.1), ou seja, a ação de demonstrar as virtudes (ou vícios) do objeto do discurso. Na sequência, explica que essa prática está incluída nos elogios fúnebres $^{68}$ e outros discursos com funções públicas. Além disso, nos julgamentos

67 Tanto a Retórica de Aristóteles quanto a Retórica a Alexandre enumeram os gêneros na seguinte ordem: deliberativo, judiciário e epidítico.

68As laudationes funebres, dado seu caráter oficial, não eram consideradas meras ostentationes (cf. Pernot 1993, p. 39). 
também ocorrem elogios ou vitupérios de testemunhas ou testemunhas que elogiam o acusado. Quintiliano ainda recorda que o discurso Contra Clódio e Curião, que Cícero apresentou no Senado, contêm vitupérios.

Por um lado, a matéria do gênero epidítico tem como objetivo a exibição; por outro, os oradores tratam também de assuntos que não são duvidosos. Quintiliano explica que às vezes o elogio exige comprovação, seja em assuntos particulares ou aqueles preparados para exibição (3.7.4). Alguns argumentos podem ser inclusive tendenciosos, "até mesmo penderão para o lado da defesa" (3.7.6). A partir desse ponto, Quintiliano expõe como se fazem elogios de homens e deuses, inclusive de animais e até mesmo de seres inanimados. É uma prescrição que ocupa seis seções do capítulo 7 (3.7.7-13), onde ele discorre sobre o domínio de cada objeto e sua forma de tratar cada um deles. Essa passagem recorda os exercícios preparatórios das escolas de declamação, retomadas na época imperial.

Laurent Pernot (1993, p. 60 ss.) relata que, na época imperial, o jovem, antes de ingressar na escola regular de retórica, começava com exercícios preparatórios (progymnasmata), cujas composições tinham como tema o elogio de heróis mitológicos ou grandes personagens históricos. Esses exercícios preliminares antecediam as declamationes, que já se encontravam em um nível superior da aprendizagem retórica e abarcavam suasórias (discursos deliberativos) e controvérsias (discursos judiciais). Essa prática oratória, com provável origem na época clássica, foi desenvolvida no período helenístico. Quintiliano a questiona porque exclui das declamações os discursos de elogio. Na Institutio Oratoria, elogio e vitupério são incluídos nas declamationes, como um treinamento que prepara o orador para elaborar trechos de oratória epidítica que poderiam ser inseridos em seus discursos deliberativos ou judiciais 69.

Na época imperial, explica Pernot (1993, p. 63), a eloquência epidítica foi estudada mais a fundo, já que o elogio era um meio de estimular a benevolência do princeps e acabava ganhando lugar de destaque nos progymnasmata. Enquanto tradicionalmente a teoria retórica se consagrou nos discursos judiciais e deliberativos, durante o Império a pesquisa sobre o encômio ganha vitalidade. Nessa época surgem

69 Ver 2.1.10-11. 
tratados consagrados exclusivamente ao elogio, e a Institutio Oratoria é um dos poucos textos conservados que tratam do "terceiro gênero"70.

No âmbito escolar, dedicava-se encômio a animais, plantas, objetos e abstrações, bem como personagens mitológicos e históricos. Quintiliano foi pioneiro no elogio de cidades, chegando a propor o elogio de um prédio ou de uma construção como um discurso autônomo (3.7.27). Esse procedimento se explicava, segundo Pernot (1993, p. 82), pelo momento político: a função da eloquência epidítica era celebrar os feitos do imperador. Sobre o contexto social em Roma na época da escritura da Institutio tornaremos a analisar mais à frente.

\subsubsection{Gênero deliberativo}

O capítulo 7 do livro 3 termina com a seguinte explicação: "no seu conjunto, o discurso epidítico tem certa semelhança com o discurso deliberativo, porque na maioria das vezes costumam ser as mesmas coisas que são recomendadas neste, elogiadas naquele" (3.7.28. totum autem habet aliquid simile suasoriis, quia plerumque eadem illic suaderi, hic laudari solent). Sobre a matéria deliberativa, Quintiliano começa o capítulo 8, dizendo que não concorda com a finalidade que lhe foi atribuída, ou seja, que não deve estar restrita à utilidade: todo discurso tem que ser honroso, já que não é útil o que não é honroso — princípio associado à dignitas, como recomenda Cícero:

2.334. contio capit omnem vim orationis et gravitatem varietatemque desiderat. ergo in suadendo nihil est optabilius quam dignitas; nam qui utilitatem petit, non quid maxime velit suasor, sed quid interdum magis sequatur, videt. Nemo est enim, praesertim in tam clara civitate, quin putet expetendam maxime dignitatem, sed vincit utilitas plerumque, cum subest ille timor ea neglecta ne dignitatem quidem posse retineri.

"Uma assembleia popular captura todo o poder de um discurso e demanda gravidade e variedade. Portanto, na persuasão, nada é mais desejável do que a dignidade. De fato, aquele que busca a utilidade vê, não o que mais quer aquele que persuade, mas o que por vezes mais se segue. Ninguém há, com efeito, sobretudo numa cidade tão ilustre, que não julgue que se deva ambicionar

\footnotetext{
70 Do período imperial, além da Inst., L. Pernot (1993, p. 67) menciona uma passagem da Retórica
} falsamente atribuída a Aristides. 
principalmente a dignidade; mas, na maior parte dos casos, vence a utilidade, quando há o temor de não se poder, caso ela seja negligenciada, reter sequer a utilidade." 71

Se um discurso não for honroso, poderá enganar "por uma aparência de utilidade" (3.8.3. utilitatis specie) e levar a que se delibere a favor de coisas vergonhosas. No sétimo livro da Institutio, quando é explicada a dispositio e o status de qualidade, lemos: “A defesa infinitamente mais eficaz é aquela em que afirmamos que o próprio fato apresentado é honroso" (7.4.4. Defensio longe potentissima est, qua ipsum factum, quod obiicitur, dicimus honestum esse). Mesmo que a utilidade seja o fim de uma deliberação, não é um objetivo isolado, já que sempre está incluída a honestidade.

“Alguns rétores julgaram que são parte do aconselhamento o honroso, o útil e o necessário" (3.8.22. partes suadendi quidam putauerunt honestum, utile, necessarium), mas Quintiliano entende que a necessidade é intrínseca a uma deliberação: se algo não é necessário, não haveria sentido em ser aconselhado. Além disso, "uma vez que se delibera sobre fatos incertos" (3.8.25. omnis enim deliberatio de dubiis est), um terceiro fator a se considerar seria a possibilidade, ou seja, se aquilo que é aconselhado é factível.

Honestidade, utilidade e possibilidade não estão necessariamente todas presentes em um discurso, podendo ocorrer subdivisões do que é honroso, como o direito, a justiça, a piedade, a equidade etc. Igualmente, "se algo é fácil, importante, agradável, seguro, é uma questão de utilidade" (3.8.27. an sit autem facile, magnum, iucundum, sine periculo, ad quaestionem pertinet utilitatis). Às vezes, pode ocorrer de ter que deixar de lado a utilidade para defender o que é honroso; outras vezes, o contrário.

Para falar das coisas úteis, as confrontamos com as inúteis, mas também as comparamos entre si, para que se decida qual é a melhor opção. Deve-se deixar claro o que é mais favorável. Enfim, "todo discurso deliberativo nada mais é que uma comparação; temos que examinar o que vamos ganhar e como, de modo que seja possível avaliar se haverá maior vantagem naquilo que buscamos ou desvantagem no modo como tentamos obtê-lo" (3.8.34. ita fere omnis suasoria nihil est aliud quam

\footnotetext{
${ }^{71}$ Trad. Adriano Scatolin (cf. bibliografia).
} 
comparatio, videndumque quid consecuturi simus et per quid, ut aestimari possit plus in eo, quod petimus, sit commodi, an vero in eo, per quod petimus, incommodi).

$\mathrm{Na}$ deliberação, segundo Quintiliano, a utilidade envolve o tempo (melhor momento para algo), o modo de agir, a medida e a pessoa. Essa última implica o decoro, "que deve ser observado tanto em nós quanto naqueles que deliberam" (3.8.35. quae et in nobis et in iis, qui deliberant, spectanda est)

Outro ponto relevante: para exortar funcionam bem os exemplos, "porque os homens são mais facilmente levados a dar seu consentimento através da experiência" (3.8.36. quia facillime ad consentiendum homines ducuntur experimentis). Por conseguinte, é fundamental conhecer a audiência, cujo caráter é decisivo numa deliberação, posto que "é mais fácil fazer propostas honestas a pessoas honestas" (3.8.38. et honesta quidem honestis suadere facillimum est). Por outro lado, é possível sensibilizar o ouvinte através de elogios, opinião pública, vantagens futuras e até mesmo temores. Enfim, "o objetivo de um discurso deliberativo é a vantagem daquele que se tenta persuadir" (3.8.42 suasoris enim finis est utilitas eius cui quisque suadet).

O uso dos afetos tem fundamental importância na oratória deliberativa, "pois muitas vezes é preciso apaziguar ou despertar a ira; incitar os ânimos ao medo, à cobiça, ao ódio, à reconciliação" (3.8.12. nam et concitanda et lenienda frequenter est ira, et ad metum, cupiditatem, odium, conciliationem). Essa ideia é reiterada quando Quintiliano afirma: "o temor do mal tem mais importância que a esperança do bem" (3.8.40. plus valet malorum timor quam spes bonorum).

A propósito da finalidade do discurso, Quintiliano afirma que "nem sempre existe espaço para o certo no ato de persuadir" (3.8.42. non est semper rectis in suadendo locus), para logo em seguida explicar que "é preciso saber como se constrói a injustiça para empregar melhor o que é justo" (3.8.43. iniquorum ratio noscenda est, $u t$ melius aequa tueamur), eximindo-se de ensinar torpezas aos jovens.

O orador deve conhecer o caráter daquele que aconselha e assim poderá manipular suas emoções, se for esse o caso. Por sua parte, o orador deve cuidar para que seu discurso seja condizente com seu caráter, isto é, "que o que se diz a respeito dele não esteja em descordo com o que ele próprio diz" (3.8.48. providedum est ne quae 
dicuntur ab eo, qui dicit, dissentiant). Assim, recomenda-se uma abordagem mais humilde ao discursar.

Para praticar discursos deliberativos, Quintiliano recomenda as prosopopeias e afirma que "muitos foram os discursos compostos, por gregos e latinos, para que fossem apresentados por outros, cujo conteúdo devia ser adaptado à vida e à posição social do orador" (3.8.50. nam sunt multae a Graecis Latinisque compositae orationes, quibus alii uterentur, ad quorum condicionem vitamque aptanda quae dicebantur fuerunt).

$\mathrm{Na}$ declamações, os jovens aprendem principalmente suasória, sendo raras as vezes em que tratam de controvérsias, e praticam a prosopopeia, atuando segundo diversas personagens, mais do que atores de comédias, compara Quintiliano (3.8.51). As prosopopeias são situações em que alguém faz um pronunciamento como se estivesse na pele de outra pessoa, podendo envolver matérias poéticas e históricas. Na retórica elas compreendem matéria judicial, deliberativa ou demonstrativa. Por exemplo, nas escolas inventam-se temas para discursos deliberativos que se assemelham às controvérsias, combinando os gêneros deliberativo e judicial (3.8.55).

Quanto à forma, numa suasória é um equívoco tratar o discurso como totalmente oposto ao judicial. Não se devem impor inícios abruptos; é preciso um exórdio, não tão longo como numa causa no fórum, mas que seja breve e leve para introduzir o assunto. Deve-se, portanto, amenizar a impetuosidade, comum nos tribunais, e expor sua opinião sem um discurso inflamado. Além disso, é recomendável uma linguagem menos pomposa, o que se aconselha também aos declamadores. Mas, apesar das advertências, não é o que acontece, "pois os que inventam esses exercícios quase sempre gostam muito de personagens extremamente grandiosas - reis, príncipes, Senadores, o povo e de temas pomposos; assim as palavras estando à altura do assunto reluzirão pelo próprio brilho da matéria" (3.8.61. nam et personae fere magnae fingentibus placent, regum, principum, senatus, populi, et res ampliores; ita, cum verba rebus aptentur, ipso materia nitore clarescunt). Sobre esse ponto, segue a concepção de Quintiliano, ao falar da elocutio no livro 8:

8.pr.18. Non ideo tamen sola est agenda cura verborum. Ocurram enim necesse est et, velut in vestibulo protinus apprehensuris hanc confessionem meam, resistam iis qui, omissa rerum (qui nervi sunt in causis) diligentia, quodam inani circa voces 
studio senescunt, idque faciunt gratia decoris, qui est in dicendo mea quidem opinione pulcherrimus, sed cum sequitur non cum adfectatur.

"Isso não significa, no entanto que se deva cuidar somente das palavras. Dessa forma, é preciso que eu ofereça resistência direta àqueles que, cientes dessa minha recente confissão, descuidem dos assuntos (que são a parte nevrálgica da causa), dedicando-se ao estudo inútil das palavras, buscando algo de elegância; algo que, na minha opinião é admirável, mas somente quando é espontâneo e sem afetação.”

À diferença das declamações, nas deliberações reais se procede de outra maneira. A afetação deve ser evitada em todo caso, é o que sugeria Teofrasto, de acordo com Quintiliano, coincidindo com Aristóteles, que teria afirmado que a linguagem do gênero epidítico é a mais apropriada para a escrita, porque tem a ver com a exibição ,como já expusemos; o segundo gênero mais adequado à escrita seria o judicial, porque exigiria arte, até mesmo se for para enganar, se isso for útil à causa. Quanto às deliberações, elas "se sustentam na credibilidade e na prudência" (3.8.63. fide prudentiaque constarent). Nessas, já recomendara Cícero: "o discurso como um todo deve ser simples e sério, mais ornado pelas ideias que pelas palavras" (3.8.65. tota autem oratio simplex et grauis et sententiis debet ornatior esse quam verbis), citado por Quintiliano.

No final do capítulo, Quintiliano enfatiza o uso de exemplos na matéria deliberativa, porque "de certa forma a experiência é considerada como evidência de razão" (3.8.66. habeaturque experimentum velut quoddam rationis testimonium). Depois, explica que é a importância da matéria que determina a brevidade ou a abundância. Por fim, Quintiliano recomenda ao aprendiz de oratória ler obras históricas e prestar atenção aos discursos que aí aparecem, tarefa mais importante que dedicar-se a manuais de rétores. No final, Quintiliano (3.8.70) ainda inclui entre as formas de oratória deliberativa expressar uma opinião no Senado (dicere sententiam in senatu) e expor um aconselhamento ao imperador (suadere si quid consulet princeps).

Expusemos aqui um panorama do tratamento dado ao gênero deliberativo na Institutio Oratoria. O próximo capítulo da tese apresenta a relação entre a causa deliberativa e a teoria dos estados de causa proposta por Quintiliano no terceiro livro. 


\section{Capítulo 3}

A teoria dos estados de causa

A doutrina dos status é tema do capítulo 6 do livro 3 da Institutio Oratoria. Nesse livro, Quintiliano faz uma exposição preliminar da teoria, sem deter-se em suas subdivisões e tampouco relacionar os status com suas funções na invenção e na disposição retóricas. O aprofundamento dessa matéria ocorre no livro 7, onde detalha sua aplicação.

Nossa explanação sobre os status está dividida em duas partes. $\mathrm{Na}$ primeira - Quid sit status —, faremos uma exposição da teoria dos status segundo Quintiliano, complementando a explicação com informações e exemplos contidos no livro 7, não sem razão considerado complementar do terceiro livro da Institutio.

$\mathrm{Na}$ segunda parte - O sistema das stáseis de Hermágoras de Temnos na Institutio Oratoria —, faremos uma comparação entre a teoria dos estados de causa exposta por Quintiliano e a doutrina de Hermágoras de Temnos, a quem é atribuída a criação desse sistema. Nesta parte, tentaremos mostrar que as diferenças de abordagem entre ambos os autores, bem como seus desdobramentos, indicam relevante contribuição da Institutio Oratoria para a arte retórica.

\subsection{Quid sit status}

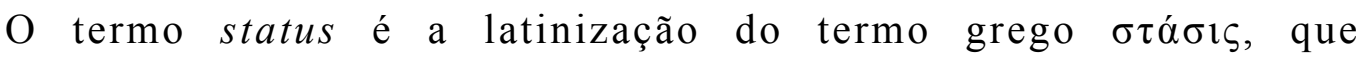
originalmente significa "posição", "situação", ou “o lugar no qual alguém deve ou deveria permanecer em pé” e, por extensão, entende-se "postura ou opinião assumida por alguém", definindo uma posição política, moral, intelectual72. No contexto retórico, o termo status corresponde ao "ponto

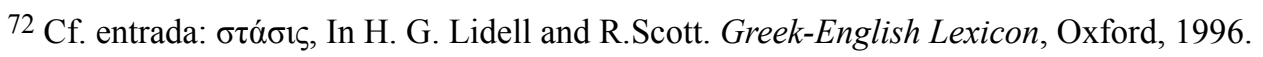


no qual duas partes oponentes se debatem"73, ou seja, a proposição na qual se fundamenta a causa e que ambas as partes - acusação e defesa - têm que demonstrar. Alguns autores latinos empregaram denominações distintas para status: constitutio74 ("constituição"), quaestio ("questão"), alii quod ex quaestione appareat ("aquilo que se origina na questão"), caput $^{75}$ ("ponto capital").

Em sua análise, Lucia Calboli Montefusco (1986, p. 2) propõe duas interpretações para status; na primeira, derivada da imagem de uma luta entre dois adversários, status seria um ponto ou posição a ser defendida por cada combatente; na segunda, derivada da própria função do status, este seria a sustentação de uma causa, ou seja, aquilo sobre o que se fundamenta a controvérsia. Precisamente é o que explica Quintiliano, ao dizer que a nomenclatura deriva "do fato de que nele se encontra o primeiro embate da causa, ou de que a causa baseia-se nele" (3.6.4. ex eo, quod ibi sit primus causae congressus vel quod in causa consistat) e que, embora sejam muitas as formas, o sentido é o mesmo. Desde que contenha a mesma ideia, não importa se o denominam "questão geral" ou "ponto capital geral” (3.6.21. generalem quaestionem vel caput generale dicere malet). Quintiliano adota o termo status.

Segundo o princípio geral da doutrina dos status, para que uma causa seja constituída é preciso que haja a formulação de uma acusação ( $\alpha \tau \alpha \dot{\alpha} \varphi \alpha \sigma \varsigma$, intentio, accusatio), à qual vai responder o réu, para defender-

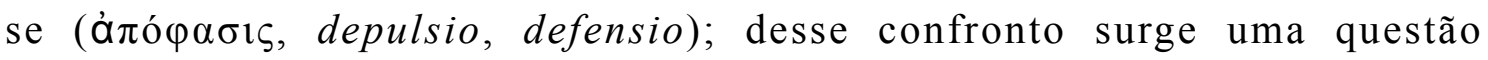

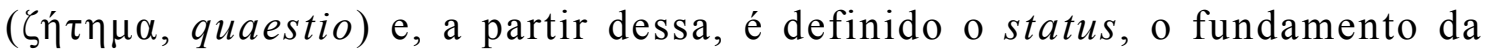
controvérsia e ponto de convergência das partes, sobre o qual se deve investigar. A quaestio, por sua vez, vai indicar o "ponto essencial a julgar"

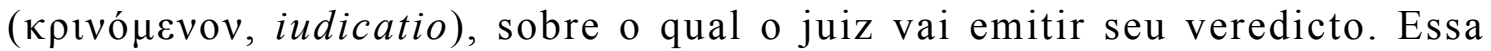

\footnotetext{
73 Entrada: status, $\sim \bar{u} s$ (m.) [stō+tus] 4 (rhet.) Oxford Latin Dicitionary, 2016.

74 Cícero, Inv. 1.14-19; Rhet.Her. 1.18. Posteriormente, Vittorino, Grillio, Cassiodoro, Isidoro, Albino e Marciano Capella (Cf. Calbuli Montefusco, 1986 p. 1).

75 Teodoro.
} 
decisão no processo depende da interpretação dos discursos das duas partes; acusação e defesa, portanto, devem empenhar-se ao máximo para que suas palavras influenciem a decisão de quem julga, o que faz do sistema dos status um dos pontos mais importantes e complexos relativos às regras da inventio.

\subsubsection{O sistema dos status na Institutio Oratoria}

Quintiliano inicia sua exposição, no sexto capítulo do livro 3, advertindo que, embora alguns autores atribuam o emprego do sistema dos status somente à causa judicial, ele próprio discorda disso e defende que a teoria seja aplicada nos três gêneros de causa.

Visto que a regra de identificação do status parte de uma causa do gênero judicial, a princípio é difícil perceber onde se encaixariam os outros tipos de discurso nessa teoria. Por esse motivo, muitos rétores teriam entendido que esse sistema estaria restrito às causas forenses. Desdobramentos da teoria, no entanto, deixarão ver que seria possível sua aplicação a qualquer tipo de causa.

A causa judicial, na Institutio Oratoria recebe, sem dúvida, espaço muito maior do que aquele conferido aos outros dois gêneros, mas o destaque à oratória jurídica pode ser explicado segundo três aspectos: as circunstâncias sociais da eloquência em Roma na época imperial, que atribuíam um papel maior da oratória aos tribunais; uma postura didática por parte de Quintiliano, que se preocupa em ensinar o que é mais frequente e, talvez, mais difícil (além disso, somente à causa judicial se aplicam as questões legais); e, sobretudo, porque ele defendia que os três gêneros estão presentes, simultaneamente, em todo tipo de causa explicando um, explicaria todos.

O tratamento da matéria judicial começa com a recomendação a professores e iniciantes na arte retórica para que primeiro aprendam quatro formas de ação, que se dividem em 3 status gerais: conjectural, de 
definição, de qualidade e um gênero de questão legal. Seguir esta ordem de procedimento é recomendado tanto à defesa quanto à acusação, como explica:

3.6.83. Nam ut a defensore potissimum incipiam, longe fortissima tuendi se ratio est, si, quod obicitur, negari portest; proxima, si non $i d$, quod obicitur, factum esse dicitur; tertia honestissima, qua recte factum defenditur. Quibus si deficiamur, ultima quidem, sed iam sola superest salus aliquo iuris adiutorio elabendi ex crimine quod neque negari neque defendi potest, ut non videatur iure actio intendi.

"Priorizando a defesa, começarei falando do primeiro, que de longe é o método mais consistente de defesa: se é possível negar aquilo de que se é acusado. O seguinte, se é possível dizer que não ocorreu o fato do qual somos acusados. O terceiro - o mais honroso - é defender que o fato se deu dentro da lei. E se não dispusermos desses argumentos, certamente há um último ponto; resta a única saída, que consiste em escapar, por meio de algum expediente do direito, de uma acusação que não é possível negar nem defender, de modo que ação pareça estar sendo apresentada ilegalmente."

A propósito da acusação, Quintiliano resume, de forma semelhante, como deve ser o procedimento: “o acusador não deve observar nada além do seguinte: o que comprova que o fato se deu, que o fato é o que ele apresenta, que o fato não é justificável, e que o processo intentado está dentro da lei" (3.6.85. accusator nihilo plura intuenda sunt, ut probet factum esse, hoc esse factum, non recte factum, iure se intendere). Os três primeiros casos envolvem, respectivamente, status de conjectura, de definição e de qualidade, coincidindo com a concepção de Cícero, no De Inventione, que diz haver em todo debate três tipos de status correspondentes às questões: “existe?"; “o que é?"; “como é?”. O último caso, que seria o status legal, Quintiliano opta por qualificá-lo como quaestio, gênero de questão (ou questão de direito). 
Enquanto no sistema de Hermágoras “status" e "questão" podem ser entendidos como termos equivalentes ${ }^{76}$, na Institutio Oratoria é clara a distinção desses termos, que discriminam os âmbitos racional e legal. Os status têm origem em questões que dependem dos fatos: sua existência (an sit), sua definição (quid sit), sua qualidade (quale sit); as questões legais estão relacionadas à estrita interpretação da lei ou parte dela. Quintiliano (3.6.88) propõe que as questões legais sejam entendidas como "simulacros" dos status racionais, ou seja, que estejam compreendidas também na conjectura, definição ou qualidade. Sistematicamente, a doutrina dos status apresentada por Quintiliano corresponde à representação do Quadro 6, a seguir:

Quadro 6 - Esquema da doutrina dos status de Quintiliano

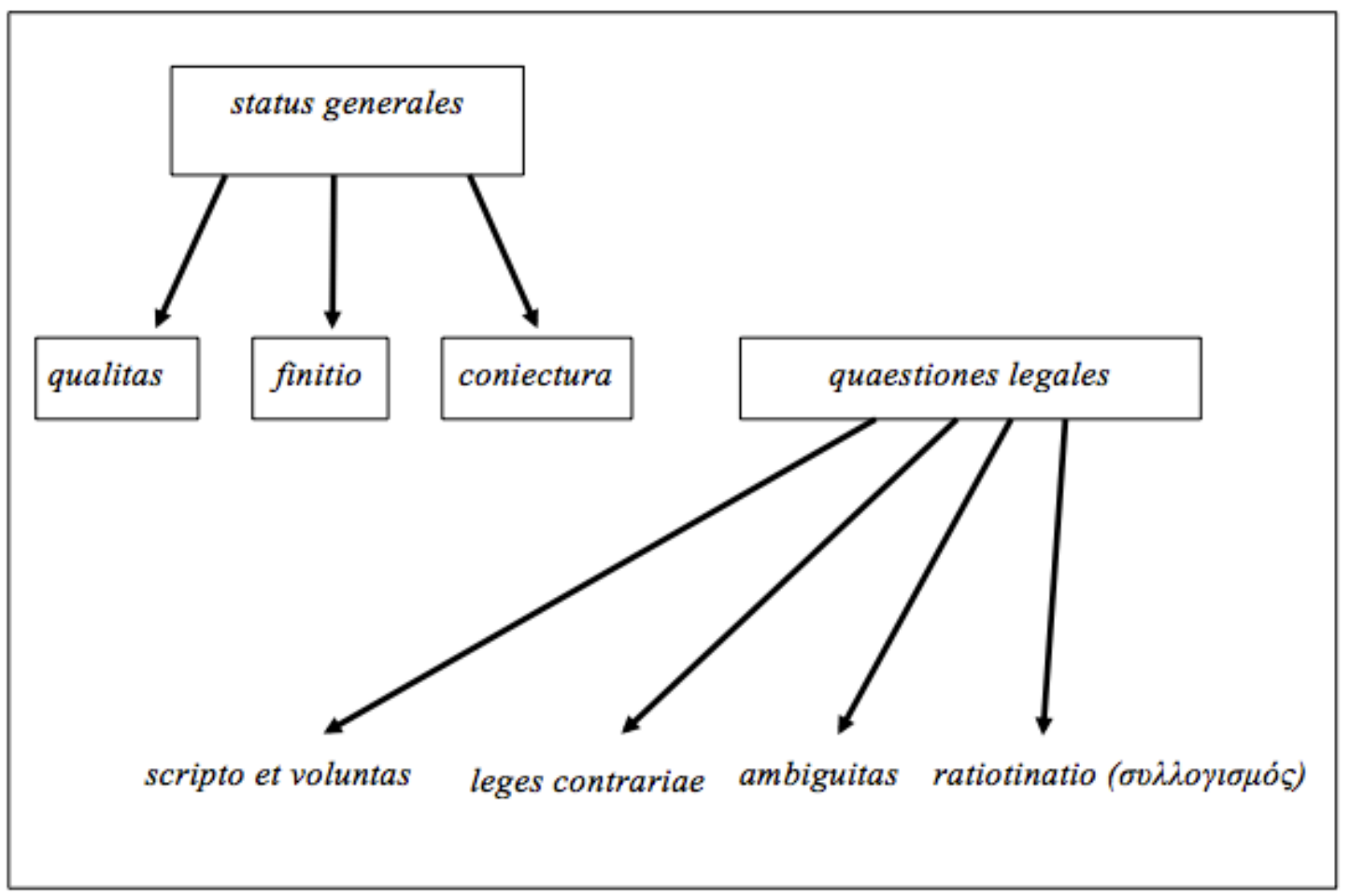

Como já dissemos, no livro 3 são apresentadas as regras gerais dos status, sem divisões e subdivisões, e ainda sem mostrar sua aplicação na

\footnotetext{
76 Barwick (1964, p. 82 ss.), comparando as testimonia (Sulp. Victor 325,5; Mart. Cap. 457,23; August. De Rh. 144,11), afirma que, na doutrina de Hermágoras, quaestio $(\zeta \eta \tau \eta ́ \mu \alpha)$ e status ( $\sigma \tau \alpha ́ \sigma ı)$ são termos empregados com o mesmo significado.
} 
invenção e na divisão - o tratamento mais detalhado dos status está no livro 7. Como um projeto pedagógico, é de se esperar que o conteúdo da Institutio seja retomado em diversos momentos, quando convier, para aprofundar os temas. Em nossa análise, nos serviremos de passagens do livro 7 que nos auxiliam e reiteram a concepção de status de Quintiliano.

Sobre a doutrina dos status na Institutio, Jean Cousin (1936, p. 176) observa que, da parte de Quintiliano "não há, de fato, nenhum esforço para ordenar seu longo capítulo e dar à sua exposição um pouco de atrativo". Herman Taylor Jr. (1971, pp. 178-9), no entanto, apesar do material "aparentemente caótico", consegue identificar uma organização do conteúdo no capítulo 6 do terceiro livro, cujo esquema seria o seguinte:

I. Apresentação do conteúdo 3.6.1;

II. Digressão sobre nominis origo 3.6.2-4;

III. Quid sit status 3.6.4-13;

IV. Unde ducatur 3.6.13.22;

V. Quod et qui sint status 3.6.23-103;

A. Histórico 3.6.23-62

1. Falsas stáseis 3.6.23-28

2. Sistemas com um a oito stáseis 3.6.29-55

3. Sistema de Hermágoras 3.6.56-62

B. Ponto de vista de Quintiliano 3.6.63-103

1. Justificativa para mudar 3.6.63.65

2. Sistema anterior de Quintiliano 3.6.66

3. Sistema atual de Quintiliano 3.6.67-79

a. Eliminação dos status legais 3.6.67

b. Eliminação da translatio 3.6.67-79

4. Sumário e apresentação pedagógica 3.6.80-103

a. Sumário 3.6.80-82

b. Explanação para estudantes 3.6.83-103

(1) Stasis em geral 3.6.83-90

(2) Causa simplex e causa coniuncta 
VI. Apreciação do conteúdo apresentado 3.6.104

Nossa análise do sistema dos status na Institutio Oratoria não seguirá a ordem em que a matéria foi apresentada no capítulo 6 do livro 3; iniciaremos mostrando a teoria do ponto de vista de Quintiliano, sem passar, neste momento, pelo histórico da matéria e sua compreensão por outros autores, que inicialmente Quintiliano apresenta nesse capítulo.

\subsubsection{Status gerais}

De acordo com Quintiliano, a maioria das autoridades no assunto divide os status em três tipos racionais - de conjectura, de definição, de qualidade - e um legal, que se subdivide em letra da lei e intenção, leis contraditórias, recapitulativo, ambiguidade, transferência, mas, a princípio, ele julga que bastam os três primeiros, já que nessa divisão tripartida "uns são racionais e outros legais" (3.6.67. alios rationales, alios legales), eliminando o status geral legal, considerado simplesmente um gênero de questão.

Quintiliano explica que excluiu também a transferência, pois entende que, na maioria das controvérsias, é difícil encontrar esse status sem que outro nome lhe tenha sido dado corretamente.

A transferência ( $\mu \varepsilon \tau \alpha \dot{\lambda} \lambda \eta \psi \iota \varsigma$, translatio) seria o quarto tipo de status racional, acréscimo de Hermágoras, como nos informa Cícero77, que

77 Cic. Inv. 1,16 In quarta constitutione, quam translativam nominatur, eius constitutionis est controversia, cum aut quem aut quicum aut quomodo aut apud quos aut iure aut quo tempore agere oporteat, quaeritur aut omnino aliquid de commutatione aut infirmatione actionis agitur. Huius constitutionis Hermagoras inventor esse existimatur, non quo non usi sint ea veteres oratores saepe multi, sed quia non animadverterunt artis scriptores eam superiores nec rettulerunt in numerum constitutionum. "No quarto status, que chamamos transferência, há uma controvérsia sobre quando seria possível questionar contra quem, de que modo, diante de qual tribunal, com que direito ou em que momento, ou, no geral, se há alguma coisa para alterar ou anular o processo. Acredita-se que Hermágoras foi o inventor desse status, não que oradores anteriores não o empregasssem - muitos o faziam com frequência mas porque os autores de manuais, anteriores a ele, não o mencionam, tampouco o incluem entre os status". Enquanto Cícero atribui a transferência a Hermágoras, Quintiliano (3.6.60), embora admita que Hermágoras tenha sido o primeiro a falar de transferência, menciona Aristóteles como o primeiro a tratar desse conceito, ainda que não o tenha nomeado como tal. 
também afirma tratar-se de uma prática jurídica frequente entre antigos oradores $^{78}$ - refere-se a um recurso jurídico, no qual o réu pode alterar ou invalidar a acusação apresentada contra ele, recorrendo a elementos circunstanciais, como o lugar, o modo, o tempo, pessoas, questionando sua validade no processo.

Segundo Quintiliano, a transferência ocorreria em causas que apresentam erros processuais — ou seja, seria um estado de causa legal —, nas quais caberiam os seguintes tipos de questionamentos: "esta pessoa tem direito de intentar uma ação?, contra este homem?, segundo esta lei?, perante este tribunal?, nesta circunstância?" (3.6.69. an huic? na cum hoc? an hac lege? an apud hunc? na hoc tempora liceat agere). Essas seriam indagações sobre o motivo da transferência de circunstâncias. Para exemplificar, segue uma das situações relatadas por Quintiliano: "deves solicitar o fideicomisso não ao pretor, e sim aos cônsules, pois a quantia é maior do que a que corresponde à jurisdição do pretor" (3.6.70. non debes apud praetorem petere fidei commissum, sed apud consules: maior enim praetoria cognitione summa est). Nesse caso, a controvérsia reside na dúvida sobre se a quantia é maior, e não na transferência de solicitação aos cônsules. "A transferência não apresenta a questão sobre a qual o orador litiga, mas por que razão litiga" (3.6.72. traslatio non habet quaestionem de qua contendit orator, sed propter qua contendit).

$\mathrm{Na}$ situação "mataste um homem"; "não matei”, o status é de conjectura porque se investiga se o acusado matou um homem. Mas no caso "tenho direito a uma ação judicial"; "não tens", a questão é se ele tem direito à ação, um status de definição, porque depende do efeito, e não da causa, ou seja, "da decisão do juiz e não do motivo da decisão" (3.6.73 non ad causam, et ad id, quod pronuntiat iudex). O status de qualidade pode

\footnotetext{
78 Calboli Montefusco (1986, pp. 139-140) informa que Hermágoras formalizou translatio ( $\mu \varepsilon \tau \alpha \lambda \varepsilon ́ \pi \sigma ı)$ ) como status, mas já se constituía um procedimento jurídico muito anterior a ele. "Tratava-se de um procedimento jurídico, correspondente a $\pi \alpha \rho \alpha \gamma \rho \alpha \varphi \eta ́$ do processo ático, na qual o réu podia invalidar por meio de exceções a acusação que lhe era imputada"(p. 140). Informações sobre esse recurso processual: Meir Schömann-Lipisius, Das attische Recht und Rechtsvorfahren, Bd. I-II-III, Leipzig, O. R. Reisland,

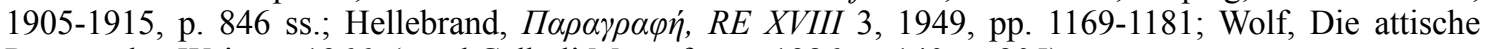
Paragraphe, Weimar, 1966. (apud Calboli Montefusco, 1986, p. 140, n. 205).
} 
ser exemplificado no caso "Horácio cometeu um crime, pois matou sua irmã"; "não cometeu um crime, porque ele tinha que matar aquela que chorava a morte de um inimigo" (3.6.76. "scelus commisit Horatius; sororem enim occidit" - "Non commisit; debuit enim occidere eam, quae hostis morte maerebat”) — aqui a questão é se ele matou com justiça.

A propósito da transferência, ou, melhor, da inexistência do status de transferência, Quintiliano estende suas explicações com diversos exemplos e conclui:

3.6.80. Credendum est igitur iis quorum auctoritatem secutus est Cicero, tria esse, quae in omni disputatione quaerantur: an sit, quid sit, quale sit. Quod ipsa nobis etiam natura praescribit: nam primum oportet subesse aliquid, de quo ambiguitur, quod, quid sit et quale sit, certe non potest aestimari, nisi prius esse constiterit: ideoque ea prima quaestio.

"Deve-se dar crédito, então, àqueles cuja autoridade Cícero seguiu, alegando que em todo debate havia três tipos de status: "existe?, o que é?, como é?", o que inclusive a própria natureza nos ensina. Primeiramente, é preciso haver algo que apresente ambiguidade, porque não é possível estimar ao certo o que é e de que natureza é se não houver acordo antes de que algo existe. Daí que esta seja a primeira questão." (3.6.80)

Lucia Calboli Montefusco (1986, pp. 140-141) explica que a inclusão da translatio nos status rationales foi amplamente contestada por rétores posteriores a Hermágoras, uns porque consideravam a transferência um status legal, e não racional; outros porque não reconheciam um valor de status na translatio, pois entrava em contradição com a própria função do status numa causa, isto é, "ao invés de dar fundamento à causa, através da translatio, o réu impedia o desenrolar normal da actio jurídica” (p. 141). Ademais, a estudiosa avalia que o rechaço explícito ao status de transferência implicaria uma rejeição tácita à doutrina de Hermágoras, considerando apenas a conjectura, a definição e a qualidade, os status racionais anteriores a Hermágoras e já presentes na tradição peripatético- 
acadêmica precedente. Essa é a postura adotada por Cícero nas obras posteriores ao De Inventione e, como mostramos, por Quintiliano.

Uma vez definido que "nenhum debate jurídico pode ser constituído de outra forma que não seja através da definição, da qualidade e da conjectura" (3.6.82. neque enim nulla disceptatio nisi finitione, qualitate, conictura potest explicari), Quintiliano segue sua exposição e explica que há uma quadripartição do método dos status (subentendemos aqui a questão legal), que compreendem todas as questões indefinidas e definidas, posto que é mais fácil para os iniciantes no assunto utilizar um procedimento mais abrangente.

A classificação das questões é apresentada em detalhe no capítulo 5 do livro 3, e antes de seguir nossa exposição sobre os status retomamos aqui dois pontos: primeiro, as questões apoiam-se em algo escrito (scriptum) ou em algo não escrito (non scriptum), e podem também ser entendidas como legales e rationales, ou seja, uma questão pode basear-se em leis ou em fatos; segundo, o orador deve tratar de questões definidas (hipóteses) e questões indefinidas (teses). Estas são mais gerais e delas derivam aquelas, que envolvem as circunstâncias ${ }^{79}$, isto é, pessoas, épocas, lugares etc. Dito isso, é preciso ter em mente que uma questão definida envolve uma indefinida - por exemplo: em "Catão deve casar-se?", essa questão definida (sobre Catão) contém em si uma questão indefinida: "é preciso que um homem se case?". Particularmente nesse sentido é que se deve entender por "tese", segundo a doutrina dos status, uma questão geral que explica uma questão circunstancial, isto é, uma hipótese (ou causa).

A seguir, analisaremos como Quintiliano explica cada um dos três status gerais e a questão legal. Seguiremos a mesma ordem apresentada no sexto capítulo do livro 3 da Institutio Oratoria, que se repete no livro 7 , onde o tema é retomado para explicar a dispositio. Do livro 7 nos servimos, sobretudo, dos exemplos e detalhamentos para explicar como

79 Dos elementos que envolvem a circuntância ( $\pi \varepsilon \rho i ́ \sigma \tau \alpha \sigma \iota \varsigma)$, Hermágoras teria determinado os sete seguintes: persona, res, causa, tempus, locus, modus, materia (cf. Calboli Montefusco, 1986, p. 34, nota 17). 
identificar um status numa causa, objeto de nossa investigação. Advertimos que os subitens a seguir - divididos segundo os status e as questões legais - apresentam um conteúdo mais expositivo, porque optamos por primeiro esclarecer a matéria, que se explica convenientemente com exemplos, para, em um segundo momento, analisála.

\title{
3.1.1.1.1. Conjectura
}

Considerando o conflito "fizeste"/"não fiz", o status conjectural surge a partir da questão "acaso ele fez?".

\begin{abstract}
7.2.7. (...) In iis autem, quae accusatione ac defensione constant, unum est genus, in quo quaeritur et de facto et de auctore; quod interim coniunctam quaestionem habet, cum utrumque partiter negatur, interim separatam, cum et de factum sit necne, et si de facto constet, a quo factum sit ambigitur.

"Nesses processos, no entanto, que consistem de acusação e defesa, o gênero é um só, segundo o qual se investiga tanto sobre o fato como sobre o autor, que ou apresenta uma questão conectada, quando ambos os pontos são igualmente negados, ou uma questão por separado, quando se indaga se o fato ocorreu ou não; e, se o fato realmente se deu, por quem foi praticado."
\end{abstract}

A conjectura sobre o fato pode envolver questões indefinidas: "se o mundo se fez a partir da reunião de átomos, se é realmente regido pela providência"; e questões definidas: "se Róscio80 cometeu parricídio, se

80 Sextus Roscius Amerius foi defendido por Cícero, quando Crisógono (Lucius Cornelius Crysogonus), liberto de Sulo, mancomunado com familiares de Róscio, tentou incluir o nome do pai de Róscio na lista de proscristos, acusando o filho de ter assassinado o próprio pai, com o intuito de apoderar-se da herança. Cícero venceu a causa. 
Mânlio ${ }^{81}$ ambicionava o reinado, se seria legítimo Quinto Cecílio acusar Verres" (7.2.2. an parricidium commiserit Roscius, an regnum adfectet Manlius, an recte Verrem sit accusaturus $Q$. Caecilius).

Embora seja possível investigar sobre o passado, presente e futuro, nos julgamentos o tempo passado é o mais importante, pois acusa-se sobre algo que já ocorreu. Além do tempo, conjectura-se sobre a qualidade do fato, que diz respeito ao modo, à espécie, ao número; por exemplo, em questões indefinidas: "se o sol é maior que a terra; se a lua é redonda, plana ou montanhosa; se existe somente um ou vários mundos" (7.2.6. an sol maior quam terra, luna globosa an plana an acuta, unus mundus an pluris); em questões definidas: "qual teria sido a maior guerra, a do Peloponeso ou a de Troia; como era o escudo de Aquiles; se existe somente um Hércules" (7.2.6-7. maius bellum Troianum an Peloponnesium, qualis clipeus Achillis, an unus Hercules). Essas são conjecturas sobre a qualidade dos fatos, cuja matéria não necessariamente é da oratória judicial.

Quando o fato for evidente, ainda é possível questionar a autoria do ato. Negar a autoria do crime não é uma questão simples, pois o réu pode apenas alegar não tê-lo praticado ou incriminar outra pessoa, o que

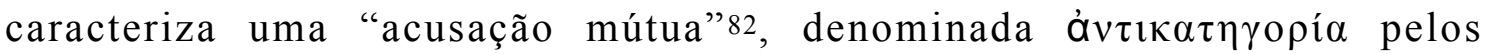
gregos, ou "acusação concertativa" por alguns rétores latinos (7.2.9). "No entanto, não existe uma maneira única de transferir o crime de uma a outra pessoa" (7.2.9. Sed ne in alterum quidem transferendi criminis una forma est.), podendo fazer-se um tipo de comparação semelhante ao de pessoas, causas, ou, ao contrário da comparação, quando ambas as partes afirmam ter praticado, ou, ainda, a acusação mútua pode estar nos fatos e não nas

\footnotetext{
81 Marcus Manlius, cônsul em 392 a.C, na crise provocada pela invasão celta (387 a.C.) defendeu a causa dos pobres contra Marcos Fúrio Camilo, tendo provocado uma rebelião, o que o levou a ser acusado de tentar tornar-se rei.

82 Desdobramentos e exemplos de "acusação mútua" seguem de 7.2.10 a 27. Celso explica que a acusação não pode ocorrer no fórum; quando há dois que se acusam mutuamente é preciso levar o caso a outro tribunal. Apolodoro, por sua vez, embora reconheça que a acusação mútua trate de duas contestações segundo o direito forense, pode ir ao Senado ou ao imperador, mas também ao tribunal, podendo haver sentença sobre as duas posições ou relativas a uma de cada vez (7.2.19-20).
} 
pessoas, e aí se questiona se o crime foi realmente praticado. Herman Taylor (1971, p. 426) observa que a acusação mútua parece ser um caso especial da $\mu \varepsilon \tau \alpha ́ \sigma \tau \alpha \sigma i \varsigma$ [metástasis] (remotio, remoção) de Hermágoras (Quadro 7, tópico 3.2 deste capítulo), porque é o caso em que a imputação do crime é transferida ao oponente ou a alguém fora da causa. Um procedimento aplicável a causas judiciais do tipo extrínseca (adsumptiva), quando elementos externos à causa são trazidos para a argumentação.

"Quando se constata o fato e identifica-se seu autor, resta inquirir sobre a disposição de espírito" (7.2.11. Cum de facto et auctore constat, de animo quaeri potest.), pois "toda conjectura trata de fatos ou de intenção" (7.2.1. Coniectura omnis aut de re aut de animo est.). Para explicar a argumentação sobre a intenção, expomos um exemplo de controvérsia (muito conhecido pelos estudantes, segundo Quintiliano):

\subsubsection{Abdicatus medicinae studuit. Cum pater eius aegrotaret,} desperantibus de eo ceteris medicis, adhibitus sanaturum se dixit, si is potionem a se datam bibisset. Pater, acceptae potionis epota parte, dixit venenum sibi datum; filius quod reliquum erat exhausit: pater decessit, ille parricidii reus est.

"Um filho deserdado estudou medicina. Quando seu pai adoeceu, estando outros médicos desesperançados de curá-lo, o filho apresentou-se e disse que o curaria se o pai bebesse uma bebida que ele the havia preparado. O pai, depois de beber um pouco da bebida, disse que lhe haviam dado veneno; o filho bebeu o resto da bebida: o pai morreu e o filho tornou-se réu, acusado de parricídio."

Neste exemplo não há dúvida sobre o fato: o pai morreu; o filho lhe deu uma bebida, isso é sabido; resta investigar se o filho queria envenenar o progenitor. Numa causa assim, não há um caminho único a seguir — é possível comparar as personalidades, os motivos, os recursos, as ocasiões, os meios, as evidências; investiga-se "se o réu teve intenção, se teve oportunidade, se cometeu" (7.2.56. an volerit, an potuerit, an fecerit.). O status é o mesmo para acusação e defesa: conjectura de intenção. 
No que tange à dispositio, Quintiliano explica que, em um questionamento sobre o fato e sobre o réu, ao acusador cabe primeiro provar que o fato ocorreu e depois que foi praticado pelo réu, mas se ele dispuser de mais informações que comprometam o criminoso, pode inverter essa ordem. Ao defensor, por sua vez, é recomendado sempre negar a existência do fato: se vencer neste ponto, não terá necessidade de recorrer a outros argumentos; se perder neste primeiro momento, terá outros recursos para sua defesa. Nas controvérsias que tratam apenas do fato, mesmo não havendo dúvida sobre a autoria, ainda é possível ter argumentos tanto sobre a pessoa como sobre o fato ${ }^{83}$.

Quintiliano apresenta a ideia de que "conjectura" (derivação de coniectus) "é uma espécie de direcionamento da razão em direção à verdade" (3.6.30. id est directione quadam rationis ad veritatem), numa tentativa de criar uma etimologia que esclareça a tradução do grego $\sigma \tau o \chi \alpha \sigma \mu o ́ s$ [stokhasmós], de $\sigma \tau o \chi \alpha ́ \zeta o \mu \alpha \imath$ [stokházomai], “apontar uma mira, acertar no alvo", donde "conjecturar, suspeitar, calcular". Essa explicação, no entanto, é subjetiva e poderíamos tomá-la como "algo de graça” (3.1.3. aliquid nitoris), que ele menciona no início do capítulo.

O status de conjectura também foi entendido como infitialis ("de negação"), termo que pode fazer referência a uma negação completa ou parcial, quando "o acusador faz uso da conjectura e o réu, da negação" (3.6.32. accusatorem coniectura, reum infitiatione uti). Neste caso, haveria dois status possíveis: o de negação e o judicial. Aqui,

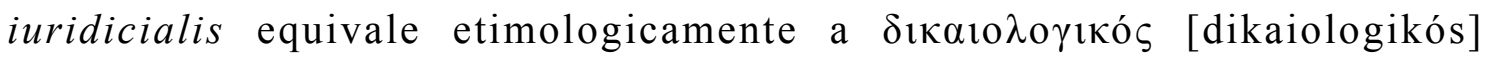
(Quintiliano menciona a forma duplicada $\left.\delta \varepsilon \delta 1 \kappa \alpha \iota \lambda \_\gamma \imath \kappa o ́ \varsigma\right)$. Na Rhetorica Rhet.Her.ennium ${ }^{84}$, o status judicial é assim definido: "a constituição (ou status) é judicial quando há acordo sobre o fato, mas pergunta-se se ele foi

\footnotetext{
${ }^{83}$ Cf. 7.2.15-16.
}

$84 \mathrm{O}$ autor anônimo (1.18-19) propõe três status: conjectural (coniecturalis constitutio), legal (legitima constitutio) e judicial (iuridicialis constitutio), subdividindo o status legal em seis: escrito e intenção (scriptum et sententia), leis contrárias (contrariae leges), ambiguidade (ambiguum), definição (definitio), transferência (translatio), analogia (ratiotinatio). 
feito justa ou injustamente" 85 (1.24. iuridicialis constitutio est, cum factum convenit, sed iure an iniuria factum sit, quaeritur).

Nos Topica (92), Cícero expõe três tipos possíveis de questão numa causa judicial: de negação (infitialis) ou conjectural (coniecturalis), de definição (definitiva) e judicial (iuridicialis). Este último tipo equivale ao status de qualidade e Cícero adverte que iuridicialis é um nome que o desagrada86. Diferentemente da concepção nos Topica, no De Inventione (1.12) - assim como na Institutio (3.6.56) —, iuridicialis designa uma das primeiras subdivisões do status de qualidade no sistema de Hermágoras, a saber: deliberativa, demonstrativa, jurídica e factual (ou pragmática). Retomaremos essa discussão quando tratarmos dos outros status.

Outra classificação da causa, segundo relata Quintiliano, é a de alguns autores que teriam proposto dividi-la em dois tipos: quando há consenso e quando não há consenso sobre o ocorrido; nesta temos status de conjectura, e naquela, os demais status (3.6.34).

Na sequência, é relatado que Apolodoro considerava haver dois tipos de questão: uma, que se encontrava em assuntos externos, que ele denominou $\pi \rho \alpha \gamma \mu \alpha \tau \imath \kappa o ́ \varsigma$ [pragmatikós] ("factual") e que explica a conjectura; outra, que se baseia em nossas opiniões, denominada de $\pi \varepsilon \rho i$ દ่vvoías [peri ennoías] ("conceitual”), dividida em qualidade e nome (i.e., definição). De modo semelhante, ainda outros autores teriam classificado os status em ả $\pi \rho \circ \lambda \eta \mu \pi \tau \imath \kappa o ́ s$ [aprolēmptikos] e $\pi \rho \circ \lambda \eta \mu \pi \tau \imath \kappa o ́ s$ [prolēmptikos], ou seja, duvidoso (dubium) e suposto (praesumptum) (3.6.35). Teodoro, por sua vez, teria defendido que se deve investigar se aconteceu o fato e quais suas conjunturas, classificando os status em essência, qualidade, quantidade e definição.

Todas essas considerações a respeito da divisão das causas demonstram que a conjectural distingue-se claramente dos outros tipos da

\footnotetext{
85 Tradução de Ana Paula Celestino Faria e Adriana Seabra (cf. bibliografia).

86 Taylor (1971, p. 230) atribui essa avaliação de molestum nomen em Cícero ao fato de que se tratava de uma nomenclatura recém-cunhada.
} 
causa. Necessariamente, quando temos uma controvérsia, a primeira situação possível é a de conjectura. Se não for conjectura, ou melhor, se há consenso entre o ocorrido, depreendem-se outras possibilidades de atuação no processo.

\subsection{Definição}

Considerando o conflito "fizeste"; "não fiz", o status de definição surge a partir da questão “o que ele fez?”. Da parte do acusador, deve-se observar: primeiro, que o fato se deu; segundo, que o fato é tal como ele o apresenta. O defensor, por sua vez, tem que demonstrar que o fato não é o que está sendo apresentado pela acusação, ou seja, caracteriza-se, por definição, de outra maneira. Este ponto é o status de definição.

A definição se aplica aos dois gêneros de questão: aquele que consiste na observação dos fatos (status racionais) e aquele que trata da observação das leis (questão legal).

Enquanto nas afirmações "não realizei um furto; não recebi pagamento; não cometi adultério" (73.1. non feci furtum, non accepi depositum, non commisi adulterium) temos status de conjectura, na sequência "isto não é um furto; isto não é um pagamento; isto não é um adultério" (7.3.1. non est hoc furtum, non est hoc depositum, non est hoc adulterium) temos status de definição. Às vezes, quando não é possível definir claramente os fatos, pode-se apelar para algo assim: "Não são maus-tratos ofender verbalmente a esposa" (7.3.2. non est male tractare uxorem verbis laedere). "Deste modo", resume Quintiliano, “a definição é a apresentação dos fatos, expressa de forma adequada, clara e breve." (7.3.2. Finitio igitur est rei propositae propria et dilucida et breviter comprehensa verbis enuntiatio).

A definição resolve a controvérsia, que se baseia nas características - gênero, espécie, diferenças, propriedades — ou no nome: 
7.3.7. Diversum est genus, cum controversia consistit in nomine, quod pendet ex scripto, nec versatur in iudiciis nisi propter verba quae litem faciunt: an, qui se interficit, homicida sit; an, qui tyrannum in mortem compulit, tyrannicida; an carmina magorum veneficium. Res enim manifesta est, sciturque non idem esse occidere se quod alium, non idem occidere tyrannum quod compellere ad mortem, non idem carmina ac mortiferam potionem; quaeritur tamen, an eodem nomine appellanda sint.

“É um tipo diferente de questão quando a controvérsia reside no nome, que depende da lei escrita e não é abordada nos julgamentos, exceto quando se tem um debate por causa da denominação: aquele que se suicida é um homicida? quem força um tirano à morte é um tiranicida? poções de um feiticeiro constituem crime de envenenamento? Seguramente os fatos são evidentes, é sabido que não é o mesmo matar-se e matar alguém, não é o mesmo matar um tirano e forçá-lo à morte, não são idênticas uma poção mágica e uma poção de veneno. Mesmo assim, questiona-se se é possível designá-los pelo mesmo nome."

Enquanto no caso do suicida ou do tiranicida está claro que não é a mesma coisa matar alguém e matar-se, ou coagir um tirano à morte e matálo, pois os fatos são evidentes, é preciso distinguir entre uma poção mágica e uma poção de veneno, já que, embora se utilize o mesmo nome, são de espécies diferentes.

Quando está definido o nome, conjectura-se a respeito da qualidade, isto é, da real natureza do fato, como a seguir:

7.3.6. Interim qualitas tractatur, ut quid sit rhetoricae, vis persuadendi an bene dicendi scientia. Quod genus est in iudiciis frequentissimum. Sic enim quaeritur, an deprehensus in lupanari cum aliena uxore adulter sit; quia non de appellatione, sed de vi facti eius ambiguitur, an omnino peccaverit. Nam si peccavit, non potest esse aliud quam adulter.

“Algumas vezes se trata da qualidade, por exemplo: o que é a retórica? a capacidade de persuadir ou a ciência de falar bem? Esse tipo de questão ocorre com muita frequência nos julgamentos. Do mesmo modo, se questiona se aquele que é surpreendido com a esposa de 
outro em um prostíbulo é um adúltero; porque não há dúvida sobre a denominação, mas sobre a natureza do fato em si, se realmente delinquiu. Pois se delinquiu, não pode ser outra coisa que um adultério".

Nesse caso, se a defesa negar tudo, temos um status de conjectura, mas se alegar que não se trata de um adultério, é preciso esclarecer que seria pecado unir-se com a mulher de outro na sua casa, não em um prostíbulo. Trata-se, então, de status de definição.

Além da conjectura e da qualidade, a definição pode estar associada também a questões legais. Neste caso, é preciso saber se o nome dado a determinado crime coincide com o que está na lei. A exatidão das palavras, muitas vezes, interfere na decisão do juiz; defesa e acusação devem buscar a segurança da clara compreensão do júri; quando for empregada, a definição deve ser adequada e ter força de persuasão, porque "uma definição pode perder seu valor de duas maneiras: quando é falsa ou quando está incompleta. Pois uma terceira maneira só ocorreria aos estúpidos, de tal modo que não estaria relacionada à questão" (7.3.23. uterque finitionem alterius impugnat. Ea duobus generibus evertitur, si aut falsa est aut parum plena. Nam illud tertium nisi stultis non accidit, ut nihil ad quaestionem pertineat).

Sempre a comprovação do fato precede a definição, ou seja, a ordem de atuação é: primeiro provar que o fato se deu; depois, do que se trata o fato em questão. Nesse ponto há uma dupla tarefa: fundamentar a definição e refutar a da parte contrária. Sobre a definição concluímos com as palavras de Quintiliano:

7.3.12. Est et talis finitionum diversitas, ut qui idem sentiant, non iisdem verbis comprehendant: ut rhetorice bene dicendi scientia, et eadem bene inveniendi et bene enuntiandi et dicendi secundum virtutem orationis et dicendi quod sit officii. Atque providendum ut, si sensu non puganant, comprehensione dissentiant. Sed de his disputatur, non litigatur. 
"Há uma tal diversidade de definições que mesmo os que pensam igual não se expressam da mesma maneira, por exemplo: retórica é a ciência de bem discursar, e igualmente a ciência de bem inventar, escolher as palavras e pronunciar segundo o caráter do discurso, e ainda expressar sua função. É preciso averiguar também se os sentidos não se opõem e se comprometem a compreensão. Mas, sobre isso se discute, não se briga."

\subsection{Qualidade}

Considerando o conflito "fizeste";"não fiz”, o status de qualidade surge a partir da questão "como é o que foi feito?", ou seja, investiga-se quais são suas características, sua natureza e forma, tamanho e quantidade. “Tudo está associado à conjectura, mas há a questão: quais são suas particularidades?" (7.4.1. Quae omnia coniectura quidem colliguntur, quaestionem tamen habent in eo, qualia sint?).

O status de qualidade que tem relação com questões gerais é muito mais frequente em causas deliberativas, mas o que trata de questões específicas ocorre mais vezes em causas judiciais, podendo passar-se da definição à qualidade, como no exemplo:

7.3.21. (...) Qui privatam pecuniam de templo surripuit, sacrilegii reus est. 22. Culpa manifesta est; quaestio est an huic crimini nomen quod est in lege conveniat. Ergo ambiguitur an hoc sacrilegium sit? Accusator, quia de templo surrepta sit pecunia, utitur hoc nomine. Reus, quia privatam surripuerit, negat esse sacrilegium sed furtum fatetur. Actor ergo ita finiet, Sacrilegium est surripere aliquid de sacro; Reus, Sacrilegium est surrupere aliquid sacri. Uterque finitionem alterius impugnat.

"Quem rouba dinheiro do templo é réu de sacrilégio. 22. A culpa é clara, a questão é se o nome deste crime é o que consta na lei. Portanto há dúvida se isto é um sacrilégio. O acusador, posto que foi roubado dinheiro do templo, emprega este nome. O réu, porque roubou dinheiro privado, nega que seja um sacrilégio, mas confessa o furto. Por consequência, o advogado assim define: 'sacrilégio é roubar algo de 
lugar sagrado'; o réu: 'sacrilégio é roubar algo sagrado'. Reciprocamente, um rebate a acusação do outro."

A solução para esse tipo de controvérsia seria, portanto, empregar o status de qualidade, questionando: "é um sacrílego aquele que roubou dinheiro privado do templo?" (3.6.41. sitne sacrilegus qui pecuniam privatam ex templo furatus est).

Como já explicamos, o acusador deve observar: primeiro, que o fato se deu; segundo, que o fato é tal como ele o apresenta, e agora - no status de qualidade - o defensor deve demonstrar primeiro que o ato foi honroso; se não, que o ato foi justo, ou então que foi útil. O acusador, por sua vez, tem que demonstrar o contrário. Em uma ação específica, é possível ainda referir-se a um lugar, quando se conhece a localização e há certeza sobre a natureza do que aconteceu.

Quintiliano estabelece uma hierarquia a ser empregada: o mais efetivo é defender o que fizemos, ou seja, que o ato foi honroso ou honesto. Se isso não for possível, devemos demonstrar que o fato foi justo. O fato pode ser justo por natureza - "aquilo praticado segundo a própria dignidade do fato" (7.4.5. quod fit secundum cuiusque rei dignitatem) ou por disposição legal. Por fím, se não nos é possível demonstrar a honra ou a justiça do fato, temos que mostrar que foi útil. Neste tipo de procedimento, não se defende o fato em si, mas alguma utilidade que ele possa apresentar, como um benefício para o Estado, para muitas pessoas ou até mesmo para o próprio adversário, e ainda em proveito de nossa causa, quando houver algo do direito que o permita ${ }^{87}$.

Para construir a defesa do fato, utilizamos, nesta ordem, os seguintes expedientes: trabalhar com dados próprios ao fato, buscar outros elementos (externos ao fato), transferência para outro tipo de crime, ou encontrar leis (proibitivas ou permissivas) que o justifiquem. Quando nada disso funcionar, apelamos para o último recurso: o pedido de desculpas. Neste

${ }^{87}$ Cf. 7.4.9. 
ponto alegamos o desconhecimento do réu, por exemplo, ou eventos de força maior que possam explicar o delito. Se não obtivermos a remissão, é possível alcançar uma diminuição da pena, reduzindo a culpa88. O pedido de clemência (deprecatio) nos tribunais não é recorrente, como explica Quintiliano: “o último é o pedido de clemência, tipo de procedimento que muitos negaram ocorrer nos julgamentos" (7.4.17. Ultima est deprecatio, quod genus causae plerique negarunt in iudicium unquam venire.). No Senado o pedido de clemência também é possível:

\subsubsection{In senatu vero et apud populum et apud principem et ubicunque iuris clementia est, habet locum deprecatio. In qua plurimum valent ex ipso, qui reus est, haec tria; vita praecedens, si innocens, si bene meritus, si spes in futurum innocenter victuri et in aliquo usu futuri; praeterea si vel aliis incommodis vel praesenti periculo vel paenitentia vedeatur satis poenarum dedisse; extra nobilitas, dignitas, propinqui, amici.}

"No Senado, porém, diante do povo, do imperador ou de qualquer jurado existe a possibilidade de clemência, onde seu pedido tem lugar e para o qual são muito importantes três aspectos relativos ao réu: sua vida pregressa, se viveu sem ofensas, se foi benemérito, se há esperança de ser um vencedor honrado e prestativo aos pósteros. Além disso, se parecer que já cumpriu pena suficiente, seja por delitos passados ou processos atuais, seja por arrependimento. Ademais dessas coisas, contam ainda a reputação, o prestígio, familiares e amigos."

Isso ocorre quando a quantidade relaciona-se à pena. Agora, quando se trata de recompensa, faz-se uma comparação: se quem solicita é merecedor de algo e, havendo dois candidatos, qual é o que mais merece (dignior) e qual é o tamanho da recompensa89. Assim resume Quintiliano:

7.4.41. Quantitas quoque, ut dixit, etiamsi non semper, plerumque tamen eidem subiect, seu modi est seu numeri. Sed modus aliquando

${ }^{88}$ Cf. 7.4.13.

${ }^{89}$ Cf. 7.4.21. 
constat aestimatione facti, quanta sit culpa, quantumve beneficium, aliquando iure, cum id in controversiam venit, qua quis lege puniendus vel honorandus:

“Também a quantidade, como expliquei, mesmo que nem sempre, mas na maioria das vezes, relaciona-se à qualidade, em dimensão ou em número. A dimensão, no entanto, algumas vezes refere-se à avaliação do fato, ao tamanho da culpa ou do benefício; outras vezes, ao direito, quando ocorrer controvérsia neste âmbito, como se, de acordo com a lei, deve-se punir ou recompensar."

No status de qualidade, a comparação pode ser utilizada entre pessoas, mas também entre ações. Por exemplo, no que diz respeito ao lugar (se morreu em casa ou numa fortificação) ou à época (em período de guerra ou paz) $)^{90}$.

Quintiliano ressalta que no status de qualidade é importante levar em consideração a atitude ou liberalidade com que se praticou um delito: analisa-se para que finalidade, em que tempo, com que disposição (animo); e, por isso, "deve ter a maior dedicação do orador, porque nela ambas as partes têm muito terreno para a engenhosidade e, numa certa medida, os afetos neste status têm maior importância" (7.4.23 Et ideo qualitas maxime oratoris recipit operam, quia in utramque partem plurimum est ingenio loci, nec usquam tantum adfectus valent.).

Embora seja ainda possível recorrer ao direito para defender o que não é possível defender pelo fato, é imprescindível manter o foco na qualidade:

7.4.24. Nam coniectura extrinsecus quoque adductas frequenter probationes habet et argumenta ex materia sumit; quale quidque videatur eloquentiae est opus; hic regnat, hic imperat, hic sola vincit. "A conjectura, certamente, seleciona, muitas vezes, provas externas e argumentos provenientes da matéria; a função da eloquência é fazer com que cada coisa pareça ter sua qualidade: neste aqui ela reina, aqui ela impera, aqui ela, sozinha, vence."

${ }^{90}$ Cf. 7.4.22. 


\subsubsection{A questão legal}

Começando pelo acusador, Quintiliano explica: “[ele] não deve observar nada além do seguinte: o que comprova que o fato se deu, que o fato é o que ele apresenta, que o fato não é justificável, e que o processo intentado está dentro da lei" (3.6.85.accusatori nihilo plura intuenda sunt, ut probet factum esse hoc, non recte factum, iure se intendere). Essas são as quatro operações em que se pode basear uma acusação e uma defesa. Os três primeiros procedimentos são do gênero racional, agora passaremos ao último recurso - por assim dizer —, a questão legal. Quintiliano expõe: "Quanto ao gênero legal é inevitável que haja várias espécies, uma vez que há muitas leis e elas têm distintos aspectos" (3.6.87. legalium plures sint species necesse est, propterea quod multae sunt leges et varias habent formas). A questão legal subdivide-se em quatro (espécies): letra da lei e intenção, leis contraditórias, silogismo, ambiguidade.

\subsection{Letra da lei e intenção}

"É a questão mais frequente entre os jurisconsultos, e a maior parte das controvérsias jurídicas está relacionada com a letra da lei e intenção" (7.6.1. Scripti et voluntatis frequentissima inter consultos quaestio est, et pars magna controversi iuris hinc pendent). Nesta espécie de questão legal investiga-se sobre a letra da lei (de scripto) ou sobre a intenção (de voluntate).

Para questionar a letra da lei existem três possibilidades. A primeira é averiguar se há obscuridade na lei (aliqua obscuritas), quando ambas as partes abordam alguma imprecisão ou um significado que favoreça seu lado. São dois exemplos de obscuridade na lei: "que o filho de uma meretriz não tome parte nas assembleias públicas. A mãe que já tinha um filho começou a se prostituir, o jovem está proibido de discursar na 
assembleia" (7.6.3. Ex meretrice natus ne contionetur. Quae filium habebat, prostare coepit; prohibetur adolescens contione) - o jovem, quando nasceu, não era filho de uma meretriz, já que sua mãe passa a se prostituir após o nascimento dele; e "que não apresente uma ação duas vezes sobre a mesma questão" (7.6.4. Bis de eadem re ne sit actio), em que há dúvida se a expressão "duas vezes" refere-se ao ator da ação ou à questão.

A segunda possibilidade de questionar a lei escrita é apresentar objeções. Um primeiro caso é quando já está evidente a impossibilidade de aplicação da lei, por exemplo em "os filhos devem sustentar os pais ou serão presos" (7.6.5. Liberi parentes alant aut vinciantur), mas não é o caso de mandar crianças para a prisão. O segundo caso é não se ater ao argumento, mas ao assunto, como na lei que proíbe escalar os muros das fortificações, determinando que quem o fizer deverá ser punido com pena capital; no entanto, no caso de um cidadão que repeliu os inimigos ao escalar o muro, argumenta-se que o fez para salvar a cidade e, portanto, a lei não se aplicaria (7.6.6-7).

A terceira possibilidade de obstar uma lei é examinar as palavras da lei que possam demonstrar outra intenção do legislador. Por exemplo: "Que seja preso aquele que for surpreendido à noite portando um objeto de ferro. Um homem com uma argola de ferro foi preso pelo magistrado" (7.6.8. Qui nocte cum ferro deprehensus fuerit, adligetur. Cum anulo ferreo inventum magistratus adligauit). Neste caso alega-se que, embora "preso" (deprehensus) esteja claro, não está evidente se o legislador queria referir-se a qualquer objeto de ferro ou a uma arma de ferro.

As objeções à intenção da lei têm lugar quando a defesa ou a acusação se apoia na letra escrita e questiona a intenção. É muito comum nos testamentos destacar a vontade do falecido referente aos herdeiros, e Quintiliano relata dois exemplos:

7.6.10. Substitutus heres erat, si postumus ante tutelae annos decessisset. Non est natus. Propinqui bona sibi vindicabant. Quis 
dubitaret, quin ea voluntas fuisset testantis, ut is non nato filio heres esset, qui mortuo? sed hoc non scripserat. 11. Id quoque, quod huic contrarium est, accidit nuper, ut esset scriptum, quod appareret scriptorem noluisse. Qui sestercium nummum quinque milia legaverat, cum emendaret testamentum, sublatis sestertiis nummis, argenti pondo posuit, quinque milia manserant. Apparuit tamen, quinque pondo dari voluisse, quia ille in argento legati modus et inauditus erat et incredibilis.

"Havia um herdeiro substituto, caso o último filho a nascer morresse antes dos anos de tutela. Ele não nasceu. Os familiares reivindicavam os bens para si. Quem duvidaria que essa tivesse sido a vontade do testador, uma vez que não teve herdeiro, quando o filho que ia nascer, nasceu morto? Mas isso não estava escrito. 11. Também existe o contrário desse caso, que aconteceu recentemente, quando estava escrito, mas parecia não ter sido a vontade do testador. Ele havia deixado a quantia de cinco mil sestércios, quando corrigiu o testamento, suprimiu a moeda 'sestércio', colocou 'moedas de prata', os 'cinco mil' permaneceram. Pareceu, no entanto, que ele queria que fossem dadas cinco moedas de prata, que era um modo inédito e surpreendente."

É preciso, portanto, buscar na intenção ou na letra do documento o que melhor expresse a vontade do testador. Todas essas questões, como explica Quintiliano, podem ser "tratadas segundo a qualidade ou a conjectura" (7.6.12. tractatus omnes qualitatis aut coniecturae).

\subsection{Leis em contradição}

Embora nenhuma lei possa ir de encontro a outra, posto que o direito é um só, duas leis podem contradizer-se em alguns pontos específicos. "Podem entrar em conflito leis diferentes e também as semelhantes ou divergentes" (7.7.3. Diversae quoque leges confligunt aut similes aut impares). Para controvérsia entre leis diferentes temos o seguinte exemplo:

7.7.4. Magistratus ab arce ne discebat; vir fortis optet quod volet: impunitatem magistratus petit. 
"Um magistrado não deve abandonar seu posto. Que um bravo varão escolha o que quiser. O magistrado pede indulto."

Entende-se que o pedido de remissão do magistrado deve-se ao fato de ele ter salvado a pátria ao abandonar seu posto. Por um lado, é possível questionar se um herói deve receber o que seja, por outro, quanto ao magistrado abandonar o posto, considera-se a eventualidade de um incêndio no Capitólio. Enfim, muitas coisas podem ir de encontro à lei escrita.

No caso de duas leis semelhantes (similes), somente pode opor-se a elas uma terceira lei, por exemplo:

7.7.5. Tyrannicidae imago in gymnasio ponatur; contra, Mulieris imago in gymnasio ne ponatur. Mulier tyrannum occidit.

“'A imagem de um tiranicida deve ser colocada em um ginásio'; ao contrário, 'A imagem de uma mulher não deve ser colocada em um ginásio. Uma mulher matou um tirano'."

Em nenhuma outra circunstância é permitido colocar a imagem de uma mulher em um ginásio público e tampouco remover a imagem de um tiranicida.

Com relação a leis divergentes (impares), deve-se rebater somente aquilo que se refere ao ponto em disputa. Quintiliano descreve o episódio de um herói que pede impunidade para um desertor. Há a lei do herói que pode pedir o que quiser, mas há também muitas objeções possíveis nessa lei e as leis escritas só poderiam ser transgredidas quando se trata da escolha de um herói.

O entendimento das leis pode ser evidente ou questionável. Quando ambas as partes estão de acordo, averigua-se qual é a mais importante ou a mais antiga. O principal é que se pratique o menos prejudicial. No exemplo do herói e do desertor, se este não for executado, que seja suspensa a lei, mas se for executado, que se ofereça outra opção ao herói. "O mais importante aqui é que se faça o melhor e o mais justo; sobre isso nada mais 
se pode ensinar do que a matéria apresentada" (7.7.8. Plurimum tamen est in hoc, utrum fieri sit melius atque aequius; de quo nihil praecipi nisi proposita materia potest).

\subsection{Silogismo}

A espécie legal que recorre ao silogismo assemelha-se à da letra da lei e intenção, podendo ir contra a letra da lei ou questionar seu princípio: "No primeiro caso, defende-se a letra e que se cumpra o que está escrito na lei; no segundo caso, defende-se que não se faça nada além do que do que está escrito" (7.8.1. illic qui verba defendit, hoc agit ut fiat utique quod scriptum est; hic, ne aliud quam scriptum est). Segundo Quintiliano, o silogismo está relacionado à definição: quando esta não é exata, abre caminho para o silogismo. "Portanto este estado de causa deduz da letra da lei aquilo que é incerto; posto que está associado à razão, é denominado raciocinativo" (7.8.3. Ergo hic status ex eo quod scriptum est id quod incertum est; quod quoniam ratione colligitur, ratiotinativus dicitur). No que se refere ao silogismo, seguem exemplos nos quais ele se aplica91:

- se o que é direito fazer uma vez também poderia ser feito mais vezes: "condenada por incesto e atirada de um precipício, ela sobreviveu; repete-se o castigo" (Incesti damnata et praecipitata de saxo vixit; repetitur);

- se o que é de direito aplicar a um, aplicá-lo a muitos: "aquele que mata a dois tiranos de uma vez, pode pedir duas recompensas" (Qui duos uno tempore tyrannos occidit, duo praemia petit);

- se o que é anterior pode aplicar-se ao que ocorre posteriormente: "o raptor fugiu, a raptada casou-se; quando o raptor voltou, a raptada exige direito de reparação" (Raptor profugit, rapta nupsit, reverso illo petit optionem);

${ }^{91}$ Cf. 7.8.3-4. 
- se o que é aplicado ao todo, aplica-se a uma parte: "não é permitido receber um arado como garantia, aceitou uma relha" (Aratrum accipere pignori non licet, vomerem accepit);

- se o que se aplica à parte, aplica-se ao todo: "não é permitido exportar lãs de Tarento; exportou ovelhas" (Lanas evehere Taranto non licet, oves evexit).

Nesses casos, quando o silogismo toma como base a lei, o acusador afirma que já está evidente na letra da lei o que deve ser feito: que atirem a incestuosa do rochedo, que a raptada tenha sua reparação; a lã está na ovelha. Por outro lado, seria possível alegar o que não consta escrito na lei: que se deve jogar uma condenada duas vezes; quando uma mulher raptada pode exigir reparação; àquele que matar dois tiranos concedam duas recompensas; nada sobre a caução de relha; nada sobre exportar ovelhas.

Sobre os exemplos de silogismo, Quintiliano destaca que o mais difícil é deduzir da letra da lei o que nela nada consta, ou seja, avaliar se o princípio de uma lei serve, por exemplo, para o seguinte caso: "aquele que matar o pai deve ser costurado dentro de um saco de couro; mas ele matou a mãe" (7.8.6. qui patrem occiderit, culleo insuatur: matrem occidit). Outro exemplo: "não é permitido tirar alguém de sua casa e levá-lo ao tribunal: ele foi retirado de uma tenda" (7.8.6 ex domo in ius educere ne liceat: ex tabernaculo eduxit).

Nos Analíticos Primeiros (I 24b 18-23), Aristóteles define silogismo como "o enunciado no qual, estabelecidas certas coisas, resulta necessariamente algo distinto do que já foi determinado por essas coisas". É uma definição geral que se pode aplicar à inferência dedutiva, sem estabelecer necessariamente duas premissas e uma conclusão, como é conhecida a operação silogística na lógica clássica. Para Quintiliano, silogismo é basicamente uma conexão de ideia, um processo dedutivo, ou, ainda, uma analogia, que permite comparar algumas leis entre si (3.6.87. alias inter se comparamus) para resolver uma controvérsia: 
7.8.7. In hoc genere quaeruntur, an, quotiens propria lex non est, simili sit utendum, an id de quo agitur ei de quo scriptum est simile sit. Simile autem et maius est et par et minus. In illo priore, an satis lege cautum sit, an, etsi parum cautum est, et hoc sit utendum. In utroque de voluntate legumlatoris. Sed de aequo tractatus potentissimi.

"Neste gênero investiga-se: a) se toda vez que não houver uma lei própria, deve-se empregar uma lei semelhante; b) se o assunto tratado é semelhante ao que está na lei escrita, e ainda se essa semelhança é maior, igual ou menor. Na primeira opção, se está suficientemente previsto na lei; em caso de que esteja superficialmente previsto, se mesmo assim deve ser empregado. Ambos os casos estão relacionados à intenção do legislador. Mas os mais efetivos são os que se baseiam na equidade."

\subsection{Ambiguidade}

Para os filósofos, segundo Quintiliano, não há uma só palavra que não tenha muitos significados, por isso são muitíssimas as espécies de ambiguidade. Mas os gêneros, por sua vez, não são tantos, porque a ambiguidade pode estar em palavras isoladas ou em grupos. Na primeira ocorrência, podemos encontrar formas coincidentes (por exemplo: gallus, que designa a ave galo e o povo gaulês), homônimos (Ájax: o herói grego ou o filho do rei Oileu, da cidade de Lócros), termos polissêmicos (como o verbo cerno: "passar pelo crivo, peneirar; distinguir, escolher; designar como herdeiro"); palavras que podem ser divididas (como ingenua, "nascida livre" e in genua, "de joelhos")92.

A segunda ocorrência de ambiguidade é quando há controvérsia em palavras agrupadas, como no caso: "Ordenou-se, em testamento, que fosse erguida uma estátua segurando uma espada, em ouro" (7.9.8. Testamento quidam iussit poni statuam auream hastam tenentem): seria toda a estátua em ouro ou somente a espada? Em outro exemplo não se identifica o

92 Cf. 7.9.2-4. 
antecedente da relativa: "Meu herdeiro deverá dar à minha esposa cem moedas de prata, de acordo com o que for escolhido" (7.9.9. Heres meus uxori meae dare damnas esto argenti quod elegerit pondo centum) escolhido por quem?

A solução da ambiguidade, muitas vezes, dá-se por alterações na construção da frase ou pela separação das palavras por meio da respiração e da pausa, do seguinte modo: argentum, quod elegerit ipse (se for o filho) ou ipsa (se for a mulher a escolher). Para o exemplo da estátua em ouro: se pronunciaria statuam, depois auream hastam, ou statuam auream e depois hastam, para, respectivamente, somente a espada em ouro, e toda a estátua em ouro, com uma espada93.

Com respeito à ambiguidade, há ainda muitas ocorrências além das já mencionadas, e não é importante enumerar todas:

7.9.14. Nec refert, quo modo sit facta amphibolia aut quo resolvatur. Duas enim res significari manifestum est et, quod ad scriptum vocemve pertinet, in utramque partem par est. Ideoque frustra praecipitur, ut in hoc statu vocem ipsam ad nostram partem conemur vertere. Nam, si id fieri potest, amphibolia non est. 15. Amphiboliae autem omnis erit in his quaestio; aliquando, uter sit secundum naturam magis sermo, sempre, utrum sit aequius, utrum is, qui scripsit ac dixit, voluerit.

"E não importa o modo como se origina a ambiguidade ou como é resolvida. Pois está claro que significa duas coisas, em relação ao que está escrito ou ao que é pronunciado, a impotância está em ambas as partes. Razão pela qual é inútil ensinar regras para tentar reverter a nosso favor a linguagem neste estado de causa, pois, se for possível fazê-1o, não haveria ambiguidade. No entanto, os casos de ambiguidade se apoiarão na seguinte questão: algumas vezes, quando a linguagem está mais próxima da natureza; sempre, quando é usada com equidade; ou segundo a intenção de quem escreveu ou disse."

\subsubsection{Simulacros}

93 Cf. 7.9.11. 
Os status gerais e seus desdobramentos (também designados “espécies") produzem simulacros, relacionando uns status a outros. Particularmente nas espécies (ou status) da questão legal operam esses simulacros. Caso da letra da lei e intenção que pode ser compreendido de variadas formas: um status racional, de conjectura, definição ou qualidade. Enquanto o silogismo associa-se à qualidade, a ambiguidade está relacionada à conjectura. É possível ainda que haja simulacros entre as espécies do gênero legal, como é o caso de leis contraditórias que podem implicar procedimentos da letra da lei e intenção. Isso ocorre porque um único status pode suscitar vários questionamentos.

Mesmo havendo uma única acusação, é provável que exista mais de um estado de causa, que a defesa deverá eleger conforme a maior probabilidade de êxito.

Nas causas complexas, que apresentam dois ou mais status, quer somente racionais, quer racionais e legais, encontra-se também uma quantidade maior de opções de procedimentos. Nesse caso está mais evidente como operam os simulacros. Para ilustrar esse sistema, Quintiliano, no final do capítulo 6 (3.6.96-103), expõe um exemplo que analisaremos a seguir.

Temos uma controvérsia sobre herança, com três demandantes, e nos encontramos com a seguinte situação: um pai teve um filho legítimo dado em adoção; um segundo filho legítimo, renegado; um filho ilegítimo (que foi conservado). Em testamento, o pai deixa a herança para o filho legítimo renegado. Para essa causa, o direito tem quatro leis, que examinaremos segundo os status cabíveis em cada uma delas.

Duas dessas leis referem-se ao status legal — "os testamentos dentro da lei sejam validados"; “os filhos de pais sem testamentos sejam os herdeiros" - e seus desdobramentos se apoiarão, consequentemente, em outras duas leis. A terceira lei — "que não receba nada do patrimônio do pai o renegado" - permite que a defesa do irmão dado em adoção e do 
ilegitimo se fundamente no status da letra da lei, enquanto a defesa do renegado se fundamenta na intenção do pai.

Agora vejamos a seguinte lei: "que o filho ilegítimo nascido antes do legítimo seja considerado filho legítimo; aquele ilegítimo que nascer depois do legítimo seja somente um cidadão e que seja lícito dá-lo em adoção; depois de dado em adoção, que lhe seja permitido voltar à família se o pai natural morrer sem filhos". De acordo com essa situação, há uma questão dupla: o ilegítimo nasceu depois ou antes dos filhos legítimos? $\mathrm{Na}$ primeira alternativa, aplica-se o silogismo, indagando se deve ser considerado não nato aquele filho que foi deserdado. Assim, o filho ilegítimo teria sido o primeiro a nascer na família e, portanto, seria legítimo. Na segunda alternativa, emprega-se o status da letra da lei e intenção, pois tendo o ilegítimo nascido antes dos legítimos seria um filho considerado legítimo. Além da letra da lei, o filho ilegítimo poderia ainda propor a situação de haver somente um filho e que esse fosse ilegítimo: qual seria a condição dele, de cidadão ou de filho? Aqui, mais uma vez, o silogismo.

Quanto ao filho dado em adoção, seu irmão legítimo (renegado) permite que ele retorne à família, mas sem direito à herança. Então, o filho dado em adoção levantará dúvidas sobre o direito à herança do renegado. Trata-se, portanto, de um deserdado que reclama herança.

“Cada um se apoiará na sua questão específica”, explica Quintiliano. O filho dado em adoção deverá se defender da segunda parte da letra da lei, que diz "depois de dado em adoção, que seja permitido voltar à família se o pai natural morreu sem filhos". Enquanto isso, o repudiado dirá que também está entre os filhos, reinterpretando a mesma lei que o deserdou, pois se fosse um estranho não teria sido necessário que o pai o repudiasse. Por outro lado, se assim o fosse, seria herdeiro de um pai sem testamento, mas, havendo um testamento, a lei o desfavorece, pois, mesmo sendo filho, não pode ser herdeiro. 
O filho ilegítimo, de sua parte, se apoiará no status de definição O que é um filho? São filhos também os não legítimos? —, tentando provar que o pai não morreu sem filhos e, uma vez que os filhos legítimos já não podem herdar, posto que um foi renegado e outro, dado em adoção, deixando de ser filhos, ele, o ilegítimo, é o único a ter direito à herança.

"Nada pode ser dito que não tenha uma razão, alguma coisa à qual se refere o julgamento e algo que contenha a essência da matéria" (3.6.104. nihil enim dicitur, cui non insit ratio et quo iudicium referatur, et quod rem maxime contineat). Com o exemplo acima, verificamos o emprego dos simulacros das três operações de uma causa: a conjectura (na letra da lei e intenção), se o renegado é filho e herdeiro; a definição, o que é um filho; a qualidade (o silogismo), o filho dado em adoção volta à família, o renegado não é filho, o testamento não é válido, e portanto o herdeiro seria o filho natural que retorna à família. Assim, se confirma a concepção do autor sobre a matéria: "Em todo gênero de causa, encontram-se uma causa (causa), um ponto a julgar (iudicatio) e um fundamento (continens)" (3.6.104. causa quoque et iudicatio et contines est in omni genera causarum).

Aqui, Quintiliano antecipa o tema do capítulo 11 do terceiro livro, a saber: quaestio, ratio, iudicatio e continens - elementos que auxiliam na identificação do estado da causa. Essa matéria faz parte da doutrina hermagoreana das stáseis, de que trataremos a seguir.

\subsection{O sistema das stáseis de Hermágoras de Temnos na Institutio}

Neste ponto da tese, vamos analisar a teoria de Hermágoras frente à exposição do método dos estados de causa na Institutio Oratoria, 
comparando, quando possível, os pontos coincidentes e as modificações que existem entre ambos os autores ${ }^{94}$.

De acordo com a reconstrução da teoria hermagoreana95, o objeto de

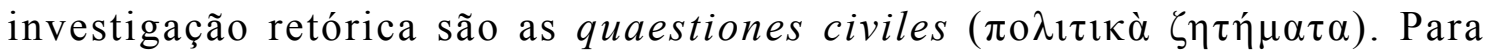
Lucia Calboli Montefusco (1986, p. 34), deve-se rejeitar a interpretação que os antigos davam a quaestiones civiles como questões de caráter geral

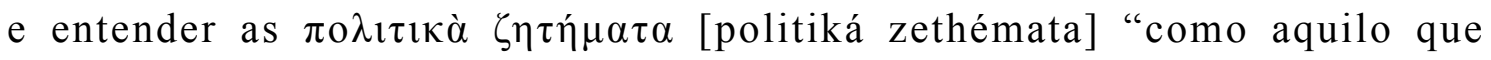

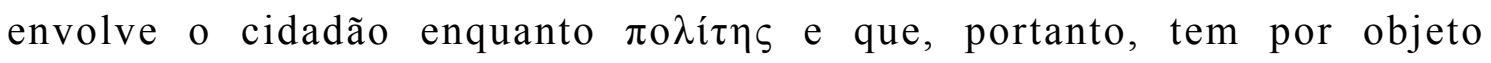
problemas judiciários e éticos".

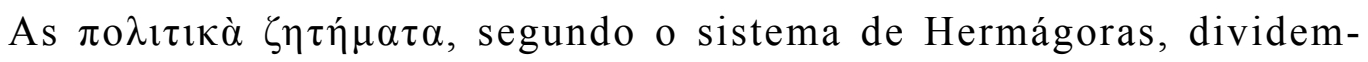

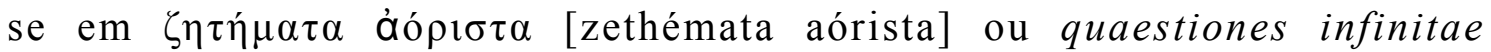
(teses), de caráter geral, sem envolver pessoas, épocas ou qualquer outro

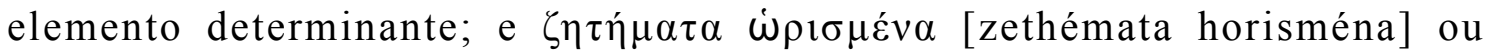
quaestiones finitae (hipóteses), que se referem a situações específicas e determinadas. Ao orador cabe tratar tanto das teses como das hipóteses, pois ambas estão inseridas nas questões civis, que é a matéria oratória

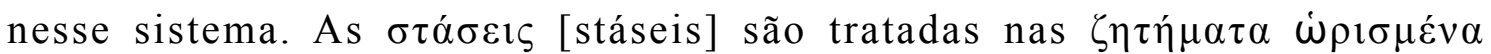

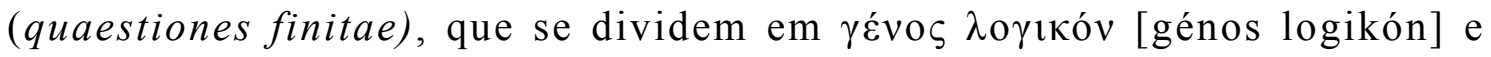

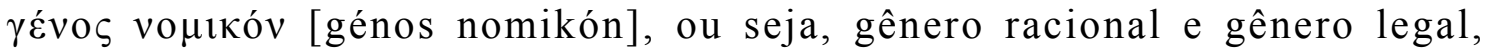
cujos desdobramentos compõem o Quadro 7, a seguir:

\footnotetext{
94 Para nossa análise, utilizamos informações sobre a reconstituição da teoria de Hermágoras em Calboli Montefusco (1986) e Barwick (1964). Cf. bibliografia.

95 Lucia Calboli Montefusco (1986, 36, em nota ad loco) cita os principais autores, cujas obras possibilitaram essa reconstrução: Mathes, HERMAGORAE TEMNITAE Testimonia et Fragmenta, Leipsig 1962; Mathes, Hermagoras von Temnos1904-1955, Lustrum 3, 1958, 58-241; Thiele, Hermagoras, Ein Beitrag zur Geschichte der Rhetoik, Strassburg 1893; Jaeneke, De statum doctrina Rhet.Her.mogene tradita, Ad rhetoricae historiam symbolae, Diss. Leipsig 1904; Kroll, Retorica VI. Die

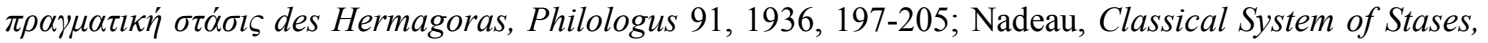
Greek, Roman, and Byzantine, Studies 1959, 53-62; Barwick, Augustins Schrift De Rhetorica und Hermagoras von Temnos, Philologus 105, 1961, 97-110. Zur Erklärung und Geschichte der Staseislehre des Hermagoras von Temnos, Philologus 108, 1964, 80-101; Zur Rekonstruktion der Rhetorik des Hermagoras von Temnos, Philologus 109, 1965, 186-218.
} 


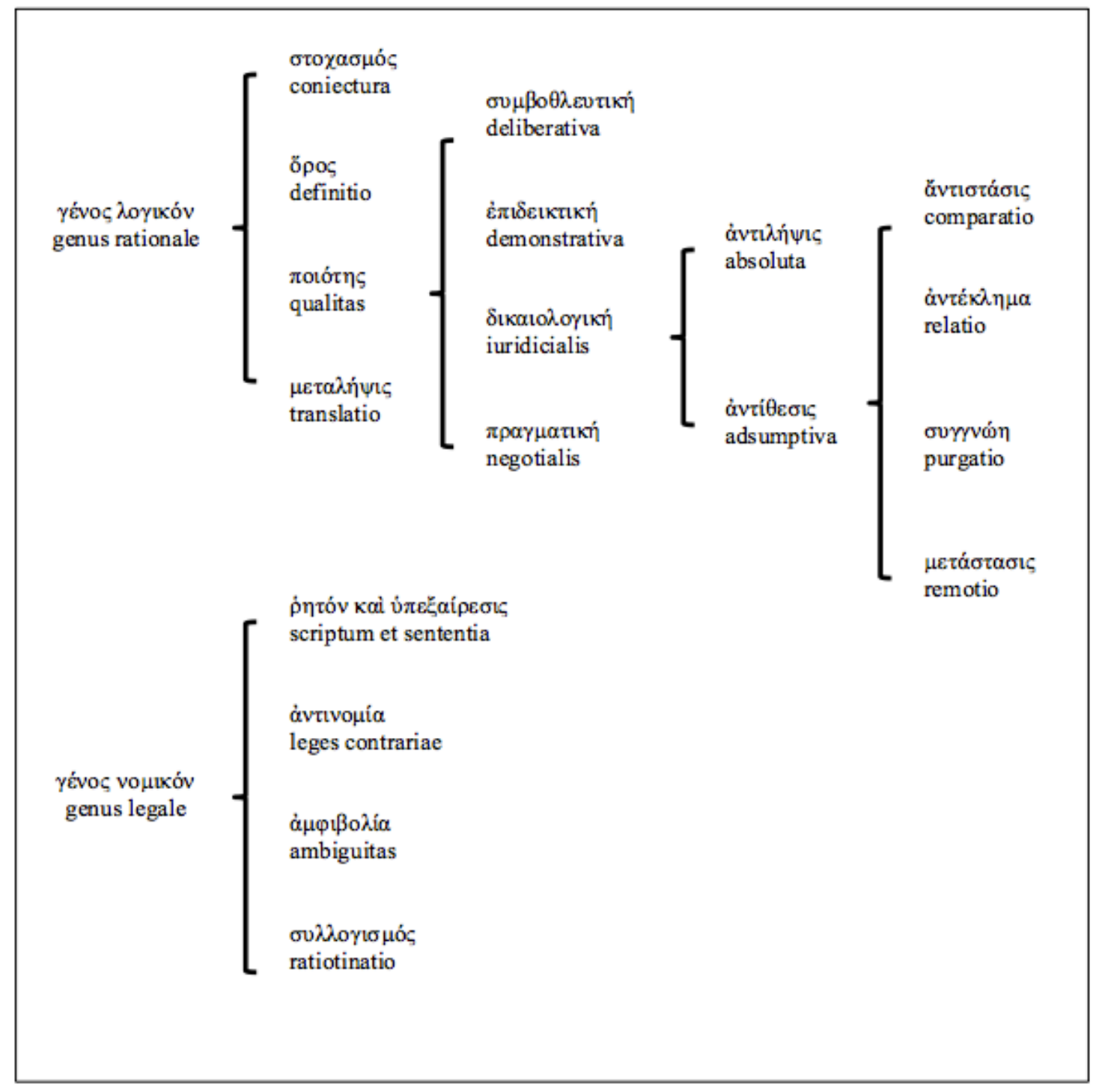

No histórico apresentado no capítulo 6 (3.6.23-62) sobre os números possíveis de status, Quintiliano informa que somente Hermágoras propôs quatro status racionais, a saber: conjectura, definição, transferência e qualidade, dividindo este último em quatro partes - deliberativa, laudativa, factual e judicial. Sobre a parte factual (negotialis) em Hermágoras, Quintiliano entende como a subdivisão do status de qualidade na qual se investigam os fatos em si, sem envolver pessoas. Cícero citado por Quintiliano - apresentou outra interpretação no De Inventione: "factual é aquela parte em que se considera o que é da área jurídica de acordo com o uso civil e a equidade. Entre nós, acredita-se que cuidar 
dessa parte é tarefa dos jurisconsultos" (3.6.58. "negotialis est in qua, quid iuris ex civili more et aequitate sit, consideratur; cui diligentiae praesse apud nos iure consulti existimantur”). Por essa passagem Cícero é desmentido, e Quintiliano atribui o suposto equívoco à imaturidade do autor do De Inventione. O ponto de vista ciceroniano, porém, parece estar correto ao explicar a parte factual do status de qualidade como matéria específica dos jurisconsultos. Barwick (1964, p. 89) ratifica que os

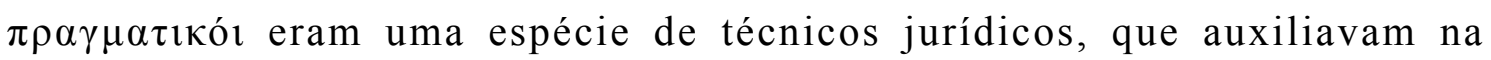
matéria do direito, quando a controvérsia não se resolveria sem o

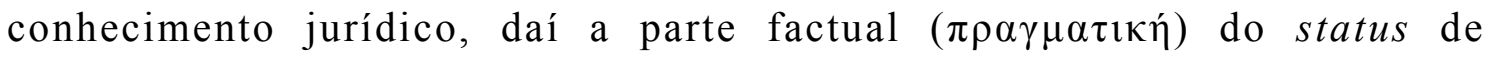
qualidade no gênero judicial.

A parte judicial do status de qualidade na teoria hermagoreana, por seu turno, divide-se em intrínseca (absoluta) e extrínseca (adsumptiva). Na primeira, defende-se um fato como justo; na segunda, o fato não é defensável por si só e é preciso recorrer a elementos externos para justificá-lo. No livro 7 da Institutio, a parte intrínseca é abordada, mas Quintiliano não a nomeia e somente explica que a defesa, no status de qualidade, deve apresentar o fato como honesto, ou seja, "devemos defender o que fizemos" (7.4.4. tuemur, quod fecimus). Esse procedimento, segundo Quintiliano, os seguidores de Hermágoras teriam denominado $\kappa \alpha \tau \alpha^{\prime} v \tau i ́ \lambda \eta \psi \iota v$, cuja correspondência em latim ele não encontrou, mas reitera: "trata-se somente de ser a questão justa ou injusta" (7.4.4. de re sola questio, iusta sit ea necne).

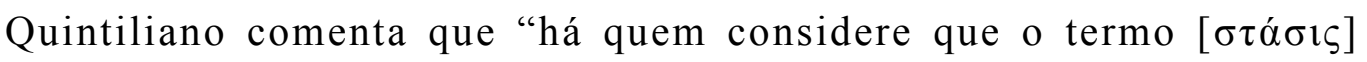
não foi inventado por Hermágoras" (3.6.3. quod nomen non primum ab Hermagora traditum putant), e levanta dúvidas sobre a cunhagem do termo, mas não sobre a autoria da doutrina. Em outra passagem, Hermágoras de Temnos é reconhecido como o "primeiro a falar em transferência" (3.6.60. tralationem hic primus omnium tradidit), ainda que Quintiliano perceba o embrião desse conceito em Aristóteles. 
Do status de transferência, já demonstramos que Quintiliano o desconsiderou entre os status racionais. Passemos às questões legais.

Hermágoras distribuiu o status legal em quatro partes: letra da lei e intenção, silogística, ambiguidade e leis contraditórias. Trata-se da mesma divisão adotada por Quintiliano, que, no entanto, alterou a nomenclatura: com a justificativa de "apresentar o mesmo material de uma maneira um pouco mais elucidativa" (3.6.65. colligere tantum eadem ac disponere paulo significantius), ele avalia que o quarto status (i.e., legal) é apenas um gênero de questão.

A diferenciação na terminologia confirma o ponto de vista defendido por Quintiliano: os status aplicam-se aos três gêneros de causa; a parte legal da matéria refere-se somente ao gênero judicial, mas não é um status - trata-se de questões de direito.

Nessa parte do capítulo 6, Quintiliano, como em outros momentos da Institutio, faz uma espécie de preâmbulo, discutindo suas decisões. Inicialmente, relata, encontrava-se constrangido em mudar aquilo com o qual já havia tempo ele não concordava; agora lhe parece honesto reconhecer os erros para que seus pósteros não continuem equivocando-se. Desse modo, sente-se à vontade para alterar preceitos de teorias anteriores (i.e., a doutrina de Hermágoras). Ainda que reverencie o mestre grego96, ele se justifica:

3.6.65. Etenim supervacuus foret in studiis longior, si nihil liceret melius invenire praeteritis. Neque tamen quicquam ex iis, quae praecepi, supervacuum fuit; ad easdem enim particulas haec quoque quae nunc praecipiam revertentur.

"A verdade é que um trabalho mais detido nesses estudos seria em vão se não fosse permitido encontrar uma exposição melhor do que as do passado. E não foi em vão, todavia, o que eu então ensinei com base nisso, pois também os preceitos que ensinarei agora servirão a estas minúcias."

\footnotetext{
96 Em 3.5.14, Quintiliano refere-se a Hermágoras como "o autor que escreveu muitas coisas sobre a arte
} retórica” (qui de hac arte mirabiliter multa composuit). 
A postura de Quintiliano — explicitada aqui — aponta para uma crítica ao detalhismo exagerado da teoria hermagoreana ou da tradição dos manuais especializados, mais especificamente os "algoritmos", na classificação proposta por Chiron (2007), na qual o tratado de Hermágoras seria o modelo da "árvore de seleção", uma tentativa de apresentar todos os casos possíveis, com o intuito de demonstrar todas as teses e todas as argumentações possíveis - uma obra muito técnica, de elaboração sistematizada e nomenclatura especializada.

No primeiro capítulo desta tese já mencionamos que os princípios de essência, definição e qualidade eram utilizados pela indagação filosófica e retórica — influência peripatético-acadêmica — anterior a Hermágoras. Este último, no entanto, tem o mérito de ter sistematizado e ampliado uma doutrina que, nas palavras de Calboli Montefusco (1986, p. 1), "na retórica antiga (...) representava sem dúvida um dos componentes mais importantes, na medida em que constituía um dos aspectos mais complexos relativos à inventio".

Adamietz (1966, p. 16) avalia que expor uma visão geral da teoria dos status no terceiro livro da Institutio foi uma medida calculada para apresentar a parte mais importante da teoria retórica, a invenção, que ele julga “o centro de interesse do autor". De fato, o sistema dos status é retomado com aprofundamento no livro 7, para explicar a dispositio do material inventariado. O conteúdo do livro 3 dá um panorama da teoria dos status, com o propósito de apresentar seus principais pontos. O foco principal é deixar claro quais são os gêneros de causa e que a esses gêneros podem ser aplicados todos os status. Dedica-se um capítulo (o capítulo 6) a discutir e apontar quantos e quais são os status e como encontrá-los. Ainda assim, não se discute no capítulo 6 quais são e como operam os elementos subjacentes da estrutura da teoria dos status, a saber:

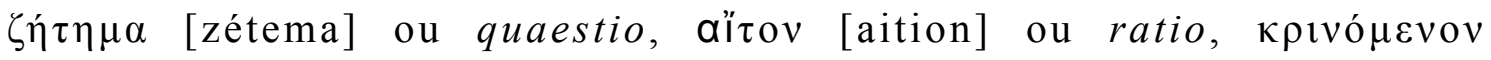

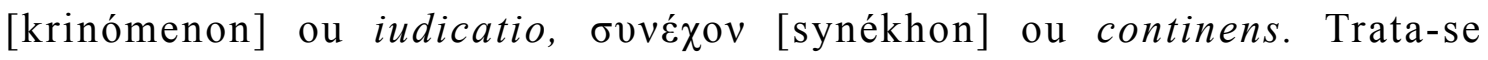


conceitos fundamentais para a compreensão do funcionamento dos status, que Malcolm Heath (1994) denominou "subestruturas da teoria das stáseis" e são o tema do último capítulo do livro 3.

No início do capítulo 11, Quintiliano afirma que, "de acordo com Hermágoras", uma vez definido o gênero de causa, é preciso "examinar o que é questão, o motivo, o ponto a julgar e o ponto central (ou, como outros dizem, o fundamento)" (3.11.1. videtur quid sit quaestio, ratio, iudicatio, continens, vel, ut alii vocant, firmamentum). Esses elementos, como vimos, foram mencionados no final do sexto capítulo, onde Quintiliano informa que deixará esse tema para depois, alegando que essa matéria apresenta interpretações variadas e que foi tratada por rétores que escrevem sobre causas judiciais.

“Em sentido amplo", explica Quintiliano, "entende-se questão como todo assunto sobre o qual se pode discutir com credibilidade segundo duas ou mais opiniões" (3.11.1. quaestio latius intellegitur omnis, de qua in utramque partem vel in plures dici credibiliter potest). Ainda que haja muitas questões numa mesma causa - "pois é consenso que uma questão dá origem a outra e que uma espécie se divide em outras (3.11.3. nam et quaestionem ex quaestione nasci et speciem in species dividi convenit) -, haverá a questão principal, que “é o ponto mais importante sobre o qual versa a causa" (3.11.2. summam illam, in qua causa vertitur), denominada

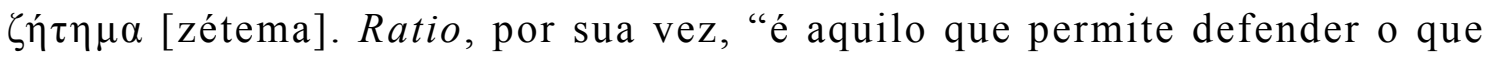
sabidamente aconteceu" (3.11.4. est qua id, quod factum esses constat, defenditur). A iudicatio é explicada no conhecido exemplo de Orestes: Clitemnestra ter matado Agamêmnon foi o motivo (aïนıov/ratio) para que Orestes a matasse; o крıvó $\mu \varepsilon v o v$ ou ponto a julgar (iudicatio), neste caso, seria: "é certo que uma mãe, ainda que criminosa, seja morta pelo filho?" (3.11.4. “an oportuerit vel nocentem matrem a filio occidi”).

A propósito do "motivo" (ratio), em sua exposição, Quintiliano

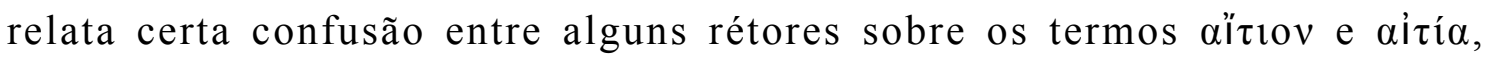
"motivo" e "causa", concluindo que, independentemente da interpretação e 
do emprego desses conceitos, os pontos a julgar serão tantos quantas forem as causas.

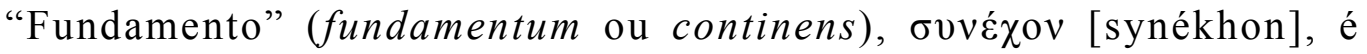
outro conceito interpretado de diferentes maneiras. Enquanto Cícero definira fundamentum como "o argumento mais eficaz da defesa e o mais adequado para a sentença do juiz" (3.11.9. firmissimam argumentationem defensoris et adpositissimam ad iudicationem), Quintiliano explica também que se entendeu como "o argumento depois do qual nada mais pode ser questionado" ou "o mais eficaz para a decisão do juiz" (3.11.9. id videtur esse post nihil quaeritur ou id quod ad iudicationem firmissimum adfertur).

Heath (1994, p. 115) afirma que não há certeza quanto aos significados desses termos, mas se sabe que já estavam na teoria das stáseis desde Hermágoras. As fontes mais antigas que nos chegaram com esses conceitos são latinas, a saber: De Inventione (1.18), Partitiones Oratoriae (104) e Rhetorica Rhet.Her.ennium (1.27). O autor anônimo explica a iudicatio na causa conjectural:

[27] In omnibus constitutionibus et partibus constitutionum hac via iudicationes reperientur, praeterquam in coniecturali constitutione: in ea nec ratio qua re fecerit quaeritur, fecisse enim negatur: nec firmamentum exquiritur, quoniam non subest ratio. Quare ex intentione et infitiatione iudicatio constituitur, hoc modo:

Intentio: "Occidisti Aiacem."

Infitiatio: "Non occidi."

iudicatio: "ocideritne?"

Ratio omnis utriusque orationis, ut ante dictum est, ad hanc iudicationem conferenda est. Si plures erunt constitutiones aut partes constitutionum, iudicationes quoque plures erunt in una causa, sed et omnes simili ratione reperientur.

“27. Em todos os status e suas partes, os pontos a julgar encontram-se por essa mesma via, exceto no status conjectural: nele não se pergunta o motivo por que algo foi feito, pois se nega o ato; nem se procura o fundamento da acusação, já que não foi apresentado um motivo. Assim, 
o ponto a julgar resulta da acusação e da ação de negá-la, da seguinte maneira:

Acusação: 'Mataste Ájax'.

Defesa: 'Não matei'.

Ponto a julgar: 'Teria ele matado Ájax?'

Todo o plano de um e outro discurso, como já foi dito, deve dirigir-se para o ponto a julgar. Se houver muitos status, ou partes de status numa mesma causa, também serão muitos os pontos a julgar, mas todos serão encontrados por um método análogo."97

"Na conjectura", explica Quintiliano, “o ponto essencial a julgar, portanto, encontra-se no mesmo lugar da questão, porque a primeira questão e a última discussão tratam do mesmo tema" (3.11.11. in coniectura ...ibi ergo iudicatio, ubi quaestio, quia in eadem re prima quaestio et extrema disceptatio). Se adotarmos os modelos propostos por Heath para explicar as subestruturas dos status, temos a conjectura no primeiro modelo:

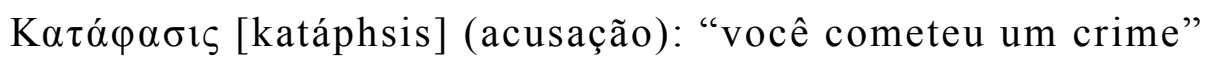

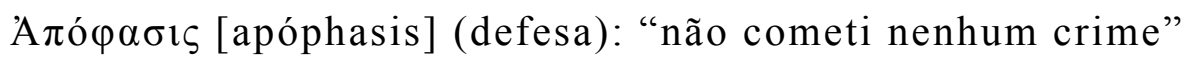

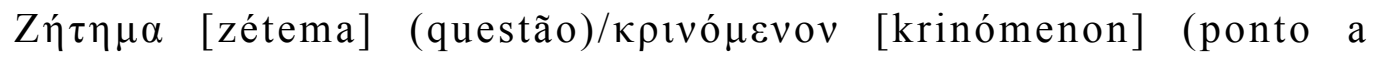
julgar): "teria ele cometido um crime?"

Sem dúvida, a estrutura da questão conjectural é simples e ela não explica o que Heath (1994, p. 115 ss.) denomina "modelos complexos" (das estruturas dos outros status), mas é o ponto de partida para entender onde encontrar o status. Reproduzimos a seguir o "modelo 1" proposto por Heath (ibid.), para entender um modelo complexo:

Modelo de causa 1

Acusação 1: "Mataste tua mãe."

\footnotetext{
97 Adaptamos a tradução de Ana Paula Celestino Faria e Adriana Seabra (cf. bibliografia), para que a tradução dos termos constitutio e iudicatio coincida com a que adotamos.
} 
Defesa 1: "Matei-a justificadamente."

Quaestio - Juiz 1: "Ele matou justificadamente?"

Defesa 2: "Por ela ter matado meu pai."

Iudicatio - Acusação 2: "Mas sua mãe não deveria ser morta por você, filho dela, seu crime poderia ser punido sem a ocorrência de um crime."

Juiz 2: "Seria certo Orestes matar sua mãe porque ela matara seu pai?"

Fundamentum - Defesa 3: “A disposição de minha mãe era tal que seus filhos, acima de tudo, estão obrigados a exigir a punição."

Esse modelo de causa explica a origem do status na primeira intervenção da defesa ("matei-a justificadamente", status de qualidade), o fundamentum como "o argumento mais eficaz da defesa e o mais adequado para a sentença do juiz" (Cic. Inv. 1.19, apud Quintiliano, 3.11.9. firmissam argumentationem defensoris et adpositissimam ad iudicationem), mas em outros modelos de controvérsia a origem do status pode variar. Por exemplo, a causa apresentada nas Partitiones (101-106) de Cícero, o segundo modelo de causa complexa98:

\section{Modelo de causa 2}

Acusação 1: "Opímio assassinou Graco."

Defesa 1: "O assassinato ocorreu dentro da lei."

Quaestio - Juiz 1: "Opímio matou Graco justificadamente?”

Ratio - Defesa 2: “Agi legalmente, para salvação de todos e preservação da república.”

Fundamentum - Acusação 2: "Nem mesmo um sujeito tão perigoso pode ser legalmente morto, antes de ser julgado.”

98 Adotamos o modelo proposto por Heath (1994, p. 118). Refere-se ao assassinto de C. Graco e seus partidários, praticado por L. Opímio, este cônsul em 121 a.C., que foi acusado de crime de LesaMajestade e, defendido pelo cônsul C. Carbão, foi absolvido. 
Iudicatio - Juiz 2: "Para preservação da república, é permitido matar um cidadão que arruinou a cidade, mas ainda não foi julgado?"

Nesse exemplo, verifica-se que o ponto a julgar é definido pela intervenção do juiz, que apresenta a questão da qual se origina o status. Servindo-se do exemplo de Orestes, o autor anônimo da Rhetorica Rhet.Her.ennium 99 (1.26) apresenta situação semelhante a essa exposta por Cícero nas Partitiones:

Modelo de causa 2 (b)

Acusação 1: "Orestes matou sua mãe."

Defesa 1: "Matei-a com justiça."

Ratio - Defesa 2: "Pois ela assassinara meu pai."

Fundamentum - Acusação 2: “Mas não deveria ser morta por ti, nem receber pena alguma sem julgamento."

Uma alternativa a esse segundo modelo, é o modelo 3 proposto por Heath (1994, p. 119), no qual não há um motivo (ratio) expresso, porque este é substituído pelo fundamentum:

Modelo de causa 3

Acusação 1: "Orestes matou sua mãe."

Defesa 1: "Matei-a dentro da lei."

Fundamentum - Defesa 2: "Pois ela assassinara meu pai."

Iudicatio - Juiz 1: “Orestes matou legalmente sua mãe, uma vez que ela assassinara o pai dele?"

A inexistência de um motivo nesse terceiro modelo é também explicada, segundo Heath (p. 119), pela "absorção" — termo do estudioso - da ratio pela segunda intervenção da defesa. Nesse caso, iudicatio seria

99 Trad. Ana Paula C. Faria e Adriana Seabra (cf. bibliografia). 
a intervenção do juiz; considerando que Orestes alega ter matado sua mãe para vingar a morte de seu pai, seria legal que Clitemnestra fosse morta por seu filho sem um julgamento?

Um último modelo proposto por Heath (1994) para exemplificar as subestruturas da doutrina do status é o que reproduzimos a seguir, cuja fonte é pseudo-Agostinho ${ }^{100}$ :

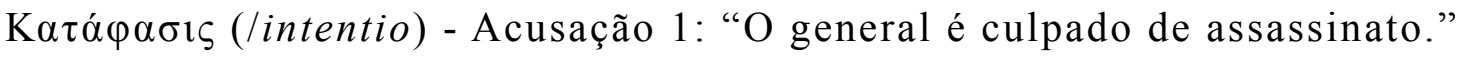

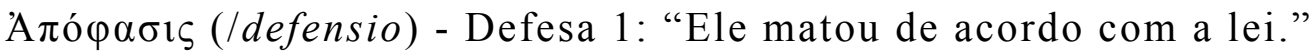

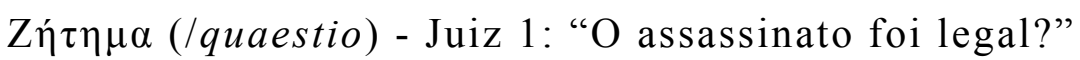
Aítıov (/ratio) - Acusação 2: "Ele matou um soldado."

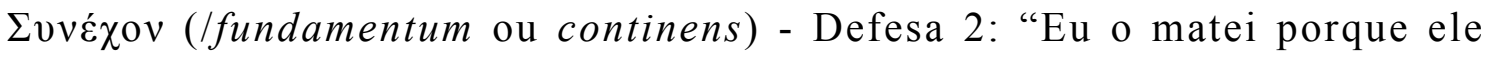
jurara que iria desertar."

Koıvónevov (/iudicatio) - Juiz 2: “É legalmente permitido a um general matar um soldado porque ele jurou que iria desertar?"

Heath (1994, p. 114) explica que o objetivo da teoria dos status é classificar problemas retóricos. Essa classificação teria grande utilidade na prática do rétor, na medida em que facilitaria a tarefa de definir uma estratégia argumentativa, apresentando padrões a uma determinada questão de fato, de acordo com a estrutura subjacente envolvida nessa questão. No entanto, os rétores antigos, segundo Heath (ibid.), nunca chegaram a um acordo no método de classificar um dado problema. Daí a grande variedade de opiniões, de que fala Quintiliano.

No início do capítulo 6 do livro 3 da Institutio, Quintiliano aponta três possibilidades para entender como surge o status. A primeira explicação seria o "primeiro conflito da causa" (3.6.4. prima causarum conflictio), definição que coincide com a primeira apresentada por Cícero no De Inventione:

${ }^{100}$ RLM 143.25 - 145.33 Halm, apud Heath (1994, p. 119). 
1.10. eam igitur quaestionem ex qua causa nascitur, constitutionem appellamus. Constitutio est prima conflictio causarum ex depulsione intentionis profecta, hoc modo: "Fecisti", Non feci", aut "Iure feci". "Chamamos, portanto, constituição (status) a questão que tem origem na causa. A constituição (status) é o primeiro conflito que surge entre a defesa e a acusação, do seguinte modo: 'fizeste'; 'não fiz' ou 'fiz dentro da lei'."

Quintiliano discorda dessa explicação de Cícero, alegando que o status não se encontra literalmente na prima conflictio, mas "naquilo que se origina no primeiro conflito" (3.6.5. quod ex prima conflictione nascitur), ou seja, uma quaestio que surge entre a intentio e a depulsio, propondo o seguinte esquema:

Acusação: "Você fez."

Defesa: "Não fiz."

Questão: "Ele fez?" ou "O que ele fez?"

De acordo com a questão que se origina, investiga-se conjectura ou definição. Considera-se a ideia de que ambas as partes se apoiam nesse conflito e, assim, o status poderia ser conjectural ou de definição. Conforme esse raciocínio, na análise de Heath (p. 123), Quintiliano reduz quaestio e iudicatio a um único conceito e subentende também o fundamentum, incluído nessa equação no sentido de que o conflito entre alegação e contra-alegação seria precisamente a matéria sobre a qual o julgamento deve ocorrer.

Em outra passagem do De Inventione, Cícero desenvolve sua concepção de origem dos status, fazendo uma distinção entre constitutio e quaestio, que não irá coincidir com a interpretação de Quintiliano:

1.18. quaestio est ea, quae ex conflictione causarum gignitur controversia, hoc modo: "Non iure fecisti"; "Iure feci",. Causarum autem est conflictio, in qua constitutio constat. Ex ea igitur nascitur controversia quam quaestionem dicimus, haec: "Iurene fecerit?". 
Causarum autem est conflictio in qua constitutio constat. Ex igitur nascitur controversia quam quaestionem dicimus haec: "Iure fecerit?" "A questão é a controvérsia que surge a partir do conflito entre as partes da causa, do tipo: 'não agiste dentro da lei'; 'agi dentro da lei'. O conflito entre as partes, no entanto, é o que determina o status. Dele deriva aquela controvérsia que chamamos questão, assim: 'Teria ele agido dentro da lei?"”

Nesta explicação de Cícero, Taylor (1971, p. 188 ss.) reconhece a aplicação da Física de Aristóteles: aqui constitutio representa a stasis com o significado de "permanecer de pé juntos", das duas partes contrárias, um impasse temporário que dá origem à questão que descreve o ponto de stasis: é o primeiro (acusação) ou o segundo (defesa) que está sendo verdadeiro?

Calboli Montefusco (1986, p. 4) esclarece que, embora evidente, a contradição pode ser sanada: "com a expressão conflictio causarum, de fato, não é indicado um momento, mas um processo dinâmico, do qual se determina o ponto de partida, a depulsione intentionis (Inv. 1,10), e também o ponto de chegada, a quaestio (Inv. 1,18)".

Outra proposta sobre a origem dos status seria, informa Quintiliano, "a primeira intervenção da defesa" (3.6.13. primam eius, cum quo ageretur, deprecationem). Para comparação, em outra fonte latina, na Rhetorica Rhet.Her.ennium temos a seguinte definição: "o status se estabelece a partir da primeira alegação da defesa em resposta à acusação do adversário" (1.18. constitutio est prima deprecatio defensoris cum accusoris insimulatione coniuncta). Enquanto em Quintiliano, nessa segunda opção, a origem do status é a primeira reação da defesa, na concepção do autor anônimo é possível também entender constitutio como a primeira alegação da defesa, mas ligada à acusação do adversário, o que pode ir ao encontro da definição de Cícero: uma noção espacial de duas asserções contrárias colocadas juntas (coniuncta). Enfim, o ponto de stasis, neste caso, seria uma permanência temporária em uma determinada posição que equivale à primeira alegação da defesa locada juntamente com 
a acusação da parte contrária. Taylor (1971, p. 191) interpreta que a fonte para esta segunda definição apresentada por Quintiliano tenha sido, direta ou indiretamente, a Rhetorica Rhet.Her.ennium, mas Quintiliano não comenta esta definição — seu interesse maior está na questão implicada nisto (unde rursus alia quaestio), ou seja, qual das partes numa causa dá origem ao status.

Então, seria possível entender a resposta inicial da defesa ("eu não fiz”) como a proposição que estabelece uma controvérsia, e daí surge o status. No De Inventione, Cícero nos informa que era essa a concepção de Hermágoras ${ }^{101}$, e o próprio Cícero a adota em obra posterior, no Topica:

CIC. Top. 93. Refutatio autem accusationis, in qua est depulsio criminis, quoniam Graece $\sigma \tau \alpha \dot{\sigma} \sigma \varsigma \varsigma$ dicitur appelletur Latine status; in quo primum insistit quasi ad repugnandum congressa defensio. Atque in deliberationibus etiam et laudationibus idem existunt status.

"A réplica da acusação, na qual reside a negação do crime, posto que os gregos a denominam stasis, pode ser chamada status em latim: é onde a defesa toma uma posição como se estivesse pronta para lutar. Também nas deliberações e nos discursos laudatórios há igualmente ocorrência de constituições (status)."

De fato, se o réu disser “não fiz”, necessariamente o adversário deverá utilizar a conjectura; mas, no caso de o réu afirmar "não tens uma lei para este caso", a acusação deverá utilizar o silogismo (ou analogia). Nesses exemplos é o réu - ao responder à acusação - que define o status. No entanto, é possível alternância entre defesa e acusação, com a acusação definindo o status, como no exemplo: "fiz, mas fiz dentro da lei". Aqui se empregaria o status de qualidade, no qual caberia à acusação provar que o crime não foi legítimo.

A recomendação de Quintiliano é seguir o que aconselha a maioria dos autores, bastando a ideia de que o status é o que se torna evidente a

101 De acordo com Cícero, "o próprio Hermágoras opina que o status consiste em refutar a acusação" (cf. Inv. 1.13. placet autem ipsi constitutionem intentionis esse depulsionem). 
partir da acusação ou da defesa. Tendo em vista que toda questão tem um status — "posto que ela se constitui de uma acusação e uma defesa" (3.6.7. constat enim ex intentione et depulsione) - e que é possível uma única causa ter várias questões, pode ocorrer de haver muitos status em uma causa. No entanto, mesmo havendo muitas opções de defesa, em uma causa simples haverá somente um ponto a julgar, consequentemente esse será o seu estado de causa: ao orador cabe demonstrá-lo e ao juiz decidir sobre ele.

A propósito das subestruturas (quaestio, ratio, iudicatio, fundamentum) dos status, Quintiliano informa que as apresentou apenas para não parecer descuidado na sua investigação. Essas subdivisões seriam um "detalhismo afetado" (3.11.21. adfectata subtilitas), com excessivas nomenclaturas e "questiúnculas insignificantes" (3.11.21. minutas rerum particulas) para o ensino da retórica.

Para Quintiliano é reprovável tantas classificações e subdivisões, vício encontrado em Hermágoras, embora "meticuloso e respeitável em muitos aspectos" (3.11.22. alioqui subtilis et in plurimis admirandus). Um método mais enxuto, sem muitas ramificações do discurso, seria mais eficaz para o aprendiz, bastando compreender o que está em controvérsia, o objetivo do adversário e seus recursos, e o principal, o que queremos alcançar.

A contribuição de Quintiliano para o método do discurso foi uma abordagem simplificativa, mas não simplista, da matéria. Ele se estende na exposição de vários pontos de vista sobre todos os temas, para, muitas vezes, resumir e apresentar o que julga realmente necessário. Essa atitude, nos parece, é o que esclarece por que ele separou a matéria dos status no livro 3: no capítulo 6 são expostas as regras fundamentais da doutrina, deixando para o último capítulo os desdobramentos da teoria. Era de se esperar, portanto, que um capítulo o sucedesse. A explicação final é de Quintiliano: 
3.11.26. Nec tam hoc praecipiendum est, ut quaestionem, continens, iudicationem inveniamus (nam id quidem facile est), quam ut intueamur semper, aut certe, si digressi fuerimus, saltem respiciamus, ne plausum adfectantibus arma excidant.

"Ensinar a encontrar a questão, o ponto central, o ponto a julgar não é tão importante (pois isso é realmente fácil) quanto recomendar manter os olhos bem abertos, ou pelo menos ter muita segurança ao olhar para trás quando fizermos uma digressão, para que na sede de aplausos não deixemos cair as armas." 


\section{Conclusão}

$\mathrm{Na}$ introdução de nossa análise do livro 3 da Institutio Oratoria, propusemos demonstrar que Quintiliano apresenta uma inovação na inventio ao conciliar a tripartição dos gêneros de causa de Aristóteles e a doutrina das stáseis de Hermágoras de Temnos.

No primeiro proêmio da Institutio, temos a afirmação de Quintiliano de que seu objetivo não é apresentar um método novo — visto que muitos autores já escreveram sobre retórica - , mas examinar e esclarecer as teorias de seus antecessores, que muitas vezes se contradizem. Ao leitor, Quintiliano deixa a tarefa de decidir qual caminho lhe parece mais conveniente seguir. Essa posição é reiterada por Quintiliano no início do terceiro livro (3.1.5), quando informa que pretende apenas oferecer um material amplo sobre a matéria para que seus leitores façam suas escolhas. No final do primeiro capítulo do terceiro livro (3.1.22), porém, Quintiliano adverte que, mesmo depois de tantas autoridades, não hesitará em manifestar sua própria opinião. Se a declaração no proêmio trata-se de "modéstia afetada" não nos cabe avaliar aqui; nosso interesse é mostrar a opinião pessoal de Quintiliano em alguns pontos no livro 3.

Sem dúvida, é grande mérito de Quintiliano reunir na Institutio Oratoria uma extensa variedade de informações de escritores de artes, desde antes de Aristóteles até sua época, conferindo-lhe uma ordem e uma unidade. No que tange à teoria dos status — tema central do terceiro livro —, as razões para acreditar que Quintiliano inovou na teoria retórica são a releitura da tripartição aristotélica dos gêneros de causa e sua adequação à doutrina dos status, bem como a expansão do sistema dos status a todo tipo de discurso. Quintiliano (3.4.1) questiona a eficácia da tripartição dos gêneros, por restringir o campo da eloquência - excluindo uma grande parte de discursos - e defende que em qualquer discurso constam todos os três gêneros.

Ao questionar a tripartição - "profundamente enraizada na mente dos antigos", na expressão da Cristina Pepe (2013, p. 260) — Quintiliano indica uma alteração na função da oratória desde Aristóteles, pois explicar a história da retórica, a importância de cada gênero de discurso e toda a sistematização ao longo de sua história é explicar o 
desenvolvimento da técnica de acordo com as necessidades e utilidades do discurso segundo a evolução e as mudanças das condições sociais e políticas.

A modificação das condições políticas é um dos fatores apontados por Chiron (2007, p. 101 ss.) que incrementaram a "capacidade de evoluir das produções no domínio da retórica". Os outros quatros fatores seriam: desgaste dos preceitos, ou seja, procedimentos retóricos que perdem sua eficácia ao serem identificados como tal; a má reputação da retórica, que era vista, em Atenas, com suspeita, por profissinalizar cidadãos em um domínio - a comunicação pública — que era, por direito, de todos; o preconceito dos optimates (elite senatorial), em Roma, que viam com maus olhos a difusão de um instrumento de poder; a doutrina isocrática, pois, além da influência decisiva - de Aristóteles, também Isócrates merece destaque nessa tradição, visto que a palavra deixou de ser mero meio de comunicação e passou a ser o "principal impulsionador da civilização". Portanto, a retórica como base de formação do cidadão fez com que a técnica sofresse transformações, não sendo mais apresentada da mesma maneira que desde sua origem.

A Institutio como um tratado total — dentro dos tratados generalistas, segundo a tipologia proposta por Chiron (2007) — seria herdeira da doutrina de origem isocrática ${ }^{102}$ que une a técnica retórica à moral (Chiron, 2007, p. 111), sendo ao mesmo tempo uma arte retórica e um programa educacional. Nesse sentido, Pierre Chiron (2007, p. 110) chama a atenção para os livros que emolduram a Institutio Oratoria: o primeiro trata da educação primária e secundária do jovem; o último (livro 12) compreende as qualidades, moral e de formação, do orador perfeito.

O terceiro livro da Institutio Oratoria pode ser analisado como uma introdução à técnica, começando a tratar da inventio. O ponto de partida é classificar os discursos, ou melhor, identificar os gêneros de causa para, na sequência, reconhecer qual status deve aplicado na causa, e a partir daí o orador poderá averiguar quais são os melhores argumentos para convencer o juiz. A classificação dos discursos é feita por meio da tripartição proposta por Aristóteles, mas a definição dos status utiliza a doutrina de Hermágoras de Temnos.

102 Herdeiro indireto, pois, segundo Chiron (2007, p. 111), Quintiliano seria o “epígono de Cícero", que se integra à tradição isocrática, na medida em que compartilha "a visão tradicional da eleoquência como cimento social e político". 
A tripartição aristotélica foi retomada por Hermágoras de Temnos, que a transportou a seu sistema das stáseis ${ }^{103}$. O rétor grego tinha como objetivo abarcar todo o campo retórico, especialmente os três gêneros oratórios 104. O tratado hermagoreano seria, na tipologia de Chiron (2007), um manual especializado do tipo "algoritmo", que se caracteriza por tentar abarcar todas as possibilidades de argumentação, sistematizando a teoria e oferecendo uma grade de soluções possíveis para um discurso efetivo.

Da doutrina das stáseis temos conhecimento através de fontes indiretas, sendo a Institutio Oratoria um de seus testimonia. Efetivamente, Quintiliano menciona Hermágoras ao longo de sua exposição, mas, enquanto na teoria de Hermágoras, as partes judicial, deliberativa e epidítica pertencem ao status racional de qualidade, em Quintiliano não temos essa exatidão da teoria hermagoreana. Com efeito, mostramos que o mestre latino faz crítica ao detalhismo exagerado de Hermágoras. Além disso, há significativos indícios de que Quintiliano, seguindo Cícero - particularmente nas Partitiones Oratoriae —, optou por reduzir os status a somente três tipos, porque a conjectura, a definição e a qualidade eram os tipos de questionamentos já presentes na indagação filósofica e retórica da tradição peripatético-acadêmica, anterior a Hermágoras.

Na Institutio, especificamente no livro 3, são mencionados nomes de rétores, cujas obras não chegaram a nossos dias, especialmente os da época helenística, período fértil para a retórica e oratória. Praticamente não nos chegaram nem manuais de retórica, nem discursos de oradores gregos, produzidos entre os séculos IV a.C. e I d.C ${ }^{105}$, o tratado de Hermágoras entre esses. A investigação sobre retórica grega dessa época ocorre por meio de fontes indiretas, algumas vezes pouco fidedignas, outras, incompletas.

Devido à fragilidade das fontes, tomamos cuidado, em nossa análise, ao tentar recuperar doutrinas de autores, cujas obras foram perdidas, considerando apenas os testemunhos. Um exemplo claro desse risco é o apresentado por William Fortenbaugh

\footnotetext{
${ }^{103}$ Pernot (1993, p. 32).

104 Chiron (2007, p. 112).

105 Pernot (2000, pp. 82-83).
} 
(2005) em seu artigo "Cicero as a Reportes of Aristotelian and Theofrastean Rhetorical Doctrine", que relata que toda vez que Cícero menciona Teofrasto - que é sempre citado em matéria retórica, mas todos os seus textos foram perdidos — faz acréscimos próprios, às vezes com "exageros na desonestidade", expressão de Fortenbaugh. Em seu artigo, o estudioso analisa passagens de obras ciceronianas que comprovam essa atitude.

Além disso, é praxe entre escritores de retórica citar autoridades no assunto, seja para impressionar os leitores, seja para demonstrar sua erudição e, assim, legitimar sua obra - ou seja, mesmo conhecendo muitos autores e textos, sempre haverá uma contribuição pessoal a ser feita e, justamente ao perceber que falta algo a ser dito, encontra-se razão para um novo trabalho.

Em nossa análise do livro 3, nos guiamos pelas informações contidas na própria Institutio Oratoria, sobretudo no que tange à doutrina dos status. Assim, nos foi possível perceber que Quintiliano não restabelece o sistema de Hermágoras. Se a menção ao rétor grego foi programática no sentido de citar a autoridade — sempre lembrada como o inventor da doutrina das stáseis - e conferir créditos à obra, não há certeza. De fato, observamos algumas diferenças entre a teoria hermagoreana e a apresentada por Quintiliano para os status. Na Institutio simplificou-se o sistema com as seguintes alterações: 1) excluiu-se a transferência dentre os status; 2) o número de status gerais foi restrito a três - conjectural, de definição e de qualidade; 3) como consequência do item anterior, foram eliminados os status legais, passando a ser denominados "questões legais" ou questões de direito, propondo que a parte legal da questão funcione como um simulacro, ou correspondência, da parte racional. Desse modo, os simulacros podem ser entendidos como uma solução para um método mais abrangente, na medida em que permite que os três status abarquem todas as questões, em todos os gêneros de causa.

Sobre as subdivisões do status, Quintiliano (3.11.21) as menciona apenas para constar, porque ele as considera minutas rerum particulas, "detalhismo afetado" de Hermágoras. Para um método mais fácil, ao professor cabe ensinar que toda causa tem uma questão, que dá origem a um status; mesmo que uma única causa tenha muitas questões e, consequentemente, muitos status, haverá um status principal: o estado da causa, cuja iudicatio (ponto a julgar) guiará a decisão do juiz. 
O comentador Herman Taylor (1971, intr. vi) observa que, pelo fato de situar-se já no final da tradição clássica da teoria retórica — que remonta ao século V a.C. —, a matéria apresentada no livro 3 da Institutio era já muito difundida, motivo pelo qual muitos pontos nesse livro são apresentados quase de maneira esquemática, já que seu conhecimento era comum a todos. De fato, à primeira vista o conteúdo do terceiro livro pode parecer generalizado, com pouco aprofundamento em certos pontos. Mas, se fosse preciso qualificar a matéria apresentada por Quintiliano no terceiro livro de sua obra, diríamos que sua principal característica é a flexibilidade, libertanto a matéria de uma teoria engessada. Quando prescreve a doutrina dos status a todos os gêneros de causa, Quintiliano não está forçando uma prescrição inviável; está preocupado em inserir todos os gêneros em um só: o do bem dizer. 


\title{
PARTE II
}

\section{TRADUÇÃO}

\section{A FORMAÇÃO DO ORADOR}

\author{
LIVRO III
}

\section{CAPÍTULO 1}

[Sobre os autores de tratados de retórica]

1. Depois de investigar, no segundo livro, o que é a retórica ${ }^{106}$ e qual a sua finalidade, também mostrei, na medida de minhas forças, que ela também é uma arte; que é útil ${ }^{107}$; que é uma virtude ${ }^{108}$, e lhe atribui como matéria109 todos os assuntos sobre os quais é preciso falar. A partir de agora ${ }^{110}$ vou expor suas origens, de quais partes consta e mostrarei de que modo se deve descobrir e tratar cada um de seus pontos. A maior parte dos autores de manuais a circunscreveu a esses moldes, a tal ponto que Apolodoro ${ }^{111}$ se contentou somente com os discursos judiciais.

2. Estou ciente de que os estudantes de retórica esperam de mim com especial atenção esta parte do trabalho que este livro começa a tratar, e

\footnotetext{
106 A definição de Quintiliano para retórica encontra-se em 2.15.38: bene dicendi scientiam.

107 Cf. 2.16.1-19.

108 Cf. 2.20.1-10.

109 Cf. 2.21.1-24.

110 Do livro 3 ao livro 7. Aqui: unde coeperit e quibus constet. Dos livros 4 ao 6: quo quaeque in ea modo inuenienda. No livro 7: atque tractanda.

111 Ver 3.1.17 abaixo.
} 
que, com base na análise das opiniões — bastante variadas ${ }^{112}$ —, será uma tarefa particularmente árdua para mim, e tanto que talvez não proporcione um mínimo de prazer aos leitores, posto que exige uma exposição quase sem adornos dos preceitos.

3. De fato, nos demais livros tentei acrescentar alguma graça, não com a intenção de vangloriar-me de meu talento (pois para tal poderia ter escolhido matéria mais fértil), mas para com isso atrair melhor a juventude à aprendizagem daquilo que eu considero necessário a seus estudos. Se são movidos por algum gosto pela leitura, ficam mais dispostos a aprender as lições cuja explicação seca e árida poderia, receio, desviar suas atenções e sobretudo ferir tão delicados ouvidos ${ }^{113}$.

4. É por essa razão que Lucrécio afirma ter reunido em versos seus preceitos filosóficos. E, como é sabido, ele emprega o seguinte símile: “e como quando os médicos tentam dar o repugnante absinto às crianças, eles primeiro untam a boca do copo com o doce e amarelo líquido do mel"114; e assim por diante.

5. De minha parte, eu receio que este livro possa ter pouco mel e muito absinto e, no que diz respeito aos estudos, seja mais salutar que agradável. E ainda estou receoso de que tenha menos reconhecimento

112 A variedade de opiniões entre os autores de retórica é referida em 3.1.7: infinita dissensio auctorum; 3.1.18: diuersas opiniones; e mais claramente no que diz respeito ao status: sed cum in aliis omnibus inter escriptores summa dissensio est, tum in hoc praecipue uidetur mihi studium quoque diuersa tradendi fugisse (3.6.22).

113 Mesma ideia apresentada em Pérsio 1.107: Sed quid opus teneras mordaci radere uero auriculas?

114 Lucrécio 1.936-938 e 4.11-13. Em seu comentário, Taylor (1971) 13 observa que Quintiliano citava de memória. No lugar de ac ueleti e adspirant, o texto de Lucrécio apresenta as seguintes formas: sed ueleti e contingunt (livro 1); nam ueleti e inspergunt ou aspergunt (livro 4). 
pelo fato de que a maior parte de seu conteúdo não é algo que eu mesmo descobri, mas que já foi exposto por outros. Ao mesmo tempo temo que possa haver quem tenha opinião contrária e o critique, porque inúmeras autoridades, embora seguissem numa mesma direção, traçaram um caminho diferente e influenciaram seus alunos a percorrê-lo.

6. Esses discípulos, por sua vez, concordaram com o percurso escolhido, fosse ele qual fosse, e não é fácil mudar as convicções já inculcadas nos jovens, porque não há quem não prefira já ter aprendido a ter que ainda aprender.

7. Mas, como ficará patente no decorrer deste livro, há uma infinita discordância entre as autoridades ${ }^{115}$. Primeiro os escritores querem acrescentar suas descobertas em obras rudimentares e ainda imperfeitas, e então, para parecer que fazem uma contribuição pessoal ao trabalho, eles alteram até o que estava certo.

8. Dizem que depois daqueles mencionados pelos poetas ${ }^{116}$, o primeiro a promover certos debates acerca da retórica foi Empédocles. Os mais antigos autores de manuais são os sicilianos Córax e Tísias ${ }^{117}$, que foram

\footnotetext{
115 À parte a lista de Quintiliano, em Cícero também temos uma enumeração de nomes no Bruto (27, 30, 46-48) e Orador (39).

116 No Bruto (40; 50), Cícero apresenta a ideia de origem da Retórica em Homero, corroborada por Quintiliano (2.17.8) que no último livro (12.10.64) menciona personagens eloquentes da Ilíada: Menelau (Il. 3.211-15), Nestor (Il. 1.247-49) e Odisseu (Il. 3.217-223).

117 Cf. Cícero. Brut. 46.
} 
seguidos por um conterrâneo da ilha, Górgias de Leontinos, que, segundo a tradição, foi discípulo de Empédocles 118 .

9. Górgias, graças a uma extrema longevidade (ele viveu até os cento e nove anos)119, despontou na mesma época que muitos outros rétores, e por isso foi também rival daqueles que acima mencionei, sobrevivendo a Sócrates.

10.Da mesma época são Trasímaco da Calcedônia, Pródico de Ceos e Protágoras de Abdera, com quem, segundo dizem, Evatlo aprendeu, por dez mil denários ${ }^{120}$, a arte que publicou mais tarde. E ainda Hípias de Elis e Alcidamas de Eleia, que Platão chama de Palamedes.

11.E ainda Antifonte, que foi o primeiro a escrever um discurso, além disso redigiu ele próprio um manual e dizem que se defendeu brilhantemente. Também Polícrates, de quem mencionamos o discurso contra Sócrates. E

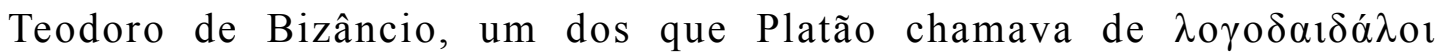
["buriladores de discurso"] ${ }^{121}$.

12.Dentre esses, Protágoras e Górgias são mencionados como os primeiros a tratar dos lugares comuns. Sobre os afetos escreveram Pródico, Hípias

\footnotetext{
118 Embora Cícero seja a principal fonte de Quintiliano, Empédocles não é mencionado em nenhum texto ciceroniano sobre retórica. O filósofo agrigentino é citado como mestre de Górgias em Diógenes Laércio (Sátiro. 8.58).

119 Mesma informação dada por Apolodoro apud Diógenes Laércio, 8.58.

120 Em em nota ad locum Jean Cousin informa que os denários são uma romanização da anedota e que Diógenes Laércio (9.52) apresenta o mesmo relato de Quintiliano, mas fala em cem minas. Em Flórida, Apuleio conta uma história parecida, colocando em cena Evatlo e Protágoras.

121 Platão, Phdr. 266e. O filósofo emprega o termo no singular, referindo-se somente a Teodoro, mas Quintiliano utiliza o plural porque tem como fonte Cícero (Orat. 39). Tradução portuguesa de José Ribeiro Ferreira, 2009.
} 
e igualmente Protágoras e Trasímaco. Cícero, no Bruto ${ }^{122}$, afirma que não há nenhum texto anterior a Péricles que apresente qualquer coisa que tenha ornato oratório, e que há referências a alguns de seus discursos 123. De minha parte, não consigo encontrar em Péricles nada que justifique tamanha reputação de eloquência, e por isso não me surpreendo tanto que considerem que ele não tenha escrito nada, e que as obras que lhe são atribuídas, na verdade, tenham sido escritas por outros 124 .

13.Muitos forma sucessores desses rétores, mas o mais brilhante discípulo de Górgias foi Isócrates 125 (ainda que não haja consenso entre as autoridades quanto a seu mestre, eu dou crédito a Aristóteles).

14. Neste ponto começaram a delinear-se caminhos diferentes. De sua parte, os discípulos de Isócrates foram notáveis em todos os ramos de estudos, e estando este já mais velho (ele chegou aos 98 anos), Aristóteles, em aulas vespertinas, começou a ensinar arte do discurso citando muitas vezes, dizem, o célebre verso do Filoctetes ${ }^{126}$ : "é vergonhoso estar calado e suportar Isócrates a falar". Ambos têm um manual, mas Aristoteles abarcou o assunto em mais livros. À mesma época pertenceu Teodectes, cuja obra citei acima.

122 Brut. 27-28; também de Orat 2.93.

123 Como observa Jean Cousin ( p.143, nota 1), Péricles não era professor de retórica.

124 Apreciação compartilhada por Plutarco (Per. 8).

125 Cf. Cícero. Orat. 176.

${ }^{126}$ Sem mencionar a fonte, Plutarco apresenta esse verso em Contra Colotes (1108b). A provável fonte de Quintiliano foi Cícero (Inv. 2.7-8; de Orat. 2.94; Brut. 32; Orat. 40), que cita o verso no De oratore (3.141) e faz alusão à rivalidade entre Isócrates e Aristoteles. 
15.Também Teofrasto, discípulo de Aristóteles, escreveu detalhadamente sobre retórica. E deste mesmo período há ainda os filósofos, com destaque para os principais estóicos e peripatéticos ${ }^{127}$, que se aprofundaram muito mais no assunto que os próprios rétores.

16. Mais tarde, Hermágoras ${ }^{128}$ traçou seu próprio caminho e teve inúmeros seguidores. Seu colega mais próximo, e rival, parece ter sido Ateneu ${ }^{129}$. Depois, Apolônio Mólon ${ }^{130}$, Areu ${ }^{131}$, Cecíliois2 e Dionísio de Halicarnasso133 fizeram contribuições importantes.

17.Mas os que efetivamente despertaram interesse foram Apolodoro de Pérgamo, professor de Augusto César em Apolônia134, e Teodoro de Gádara135, que preferia ser chamado de Teodoro de Rodes; dizem que Tibério César foi seu zeloso discípulo quando se retirou para aquela ilha ${ }^{136}$.

\footnotetext{
127 É possível mencionar entre os filósofos estóicos, Cleanto e Crisipo, que escreveram um tratado de retórica (Kennedy, (1963) pp.290-299); entre os peripatéticos, Demétrio de Falero (idem pp. 284-286).

128 Ver Kennedy (1963) pp.303-321.

129 Ver 2.15.23.

${ }^{130}$ Professor de Cícero (cf. Brut. 307, 312, 316) e célebre orador (ver Kennedy (1963) pp. 326-327).

131 Ver 2.15.36.

132 Ver Kennedy (1963) 299 nota 64.

133 Idem 263-276.

134 Cf. Suetônio, Aug. 8.89.

135 Kennedy (1963) p.335.

136 Cf. Suetônio, Tib. 57.
} 
18.Estes dois apresentaram opiniões muito particulares, daí seus seguidores serem designados apolodorianos e teodorianos137, como é costume em certas escolas filosóficas. Mas é possível conhecer os preceitos de Apodoloro principalmente a partir dos discípulos: dentre eles o que mais se dedicou a transmiti-los em latim foi Caio Válgio ${ }^{138}$; em grego, Ático139. Aparentemente o próprio Apolodoro publicou somente um manual, dedicado a Mácio ${ }^{140}$, pois numa carta a Domício ${ }^{141}$ ele não reconhece a autoria de outros manuais. Teodoro escreveu mais e teve como discípulo Hermágoras ${ }^{142}$, que algumas pessoas ainda vivas puderam conhecer.

19.Dentre os romanos, até onde sei, o primeiro a tratar dessa matéria foi Marco Catão ${ }^{143}$, o famoso censor. Depois dele Marco Antônio ${ }^{144}$ deu os primeiros passos nesse terreno, restando dele um único texto, e mesmo

137 Em 2.11.2, Quintiliano conta-nos sobre essas duas correntes. Mas, como observa Russell (trad. p.16, nota 30) elas não apresentavam pontos de vista totalmente opostos, mas abordagens diferentes para a relação entre teoria e prática na oratória.

138 Provavelmente o poeta elegíaco Caio Válgio Rufo, amigo de Horácio e a quem este dedicou a Ode 2.9. Foi cônsul substituto em 12 a.C. Teve papel importante na história da retórica por transmitir em latim os ensinamentos de Apolodoro, com destaque para a definição de causa (ver 3.5.17).

139 Provavelmente Dionísio Ático de Pérgamo, aluno de Apolodoro, historiador, rétor e logógrafo, mencionado por Estrabão (13.4.3).

140 Provavelmente C. Mátio, filho de um dos mais leais aliados de César, um amigo letrado de Augusto. (Cf. Plinio, Nat. 12.13; Tácito, Ann. 12-60)

141 Pode ser o poeta de epigramas Domício Marso, cuja obra De urbanitate Quintiliano menciona em 6.3.102-112.

142 Aqui não se trata de Hermágoras de Temnos referido em 3.1.16, mas do jovem contemporâneo de Cecílio na época de Augusto, mencionado por Sêneca, o Velho, como um declamador (cf. Con. 2.6.13).

143 Possivelmente Catão escreveu uma obra sobre retórica dedicada a seu filho, com a definição de um bom orador: uir bonus dicendi peritus; retomada por Quintiliano em 12.1.1.

144 No Do orador (1.98 e 1.208), Cícero faz Antonio falar sobre seu libellus, baseado mais na prática que na teoria. 
assim incompleto. Os seguintes são menos conhecidos, mas não deixarei de mencioná-los se em algum momento o assunto exigir 145.

20.Inigualável brilho - tanto na prática da eloquência como nos seus ensinamentos - produziu aquele que, entre nós, foi modelo único do discurso e do ensino das artes oratórias: Marco Túlio. Depois dele o mais razoável seria permanecer em silêncio, não fosse o fato de ele mesmo afirmar que a sua retórica lhe escapou das mãos ${ }^{146}$, e que intencionalmente omitiu nos seus textos sobre oratória pequenos detalhes que tantas vezes fazem falta.

21.Sobre a mesma matéria Cornifício147 fez muitas contribuições, Estertínio ${ }^{148}$, algumas. Gálio ${ }^{149}$, o pai, também escreveu alguma coisa, mas antes dele, com mais precisão, tivemos Celso ${ }^{150}$ e Lenas ${ }^{151}$; em

145 Por exemplo, em 11.3.143 Quintiliano menciona Lúcio Plótio Gallo, que também aparece no Do orador (3.93), de Cícero e nas Controvérsias (2.5) de Sêneca.

146 Sobre as publicações de sua juventude, i.e., Da Invenção, ver a opinião do próprio Cícero no Do orador 1.5. Por sua parte, Quintiliano considera obras retóricas o Do orador, Oratdor e Bruto, que não são propriamente manuais de arte oratória.

147 Provável contemporâneo de Cecílio, Dionísio e Rutílio, mencionados em 9.3.89, onde Cornifício é referido como autor de uma obra dedicada ao tratamento das figuras. Seu nome é citado em diversas passagens da Institutio $(5.10 .2$; 9.2.27; 9.3.69-71; 9.3.91 e 98) relacionadas às figuras, que contém termos ou exemplos coincidentes com os da Retórica a Herênio.

148 Nada se sabe sobre o rétor Estertínio.

149 Famoso orador nos períodos de Augusto e Tibério. Quintiliano emprega o termo pater para distinguilo do filho que este adotou de seu amigo Sêneca, o Velho. (cf. Con. 10 praef.13).

150 Enciclopedista da época de Tibério, Aulo Cornélio Celso escreveu sobre agricultura, estratégia militar, retórica, filosofia e jurisprudência (cf. 12.11.24). É mencionado em diversas passagens da Institutio, por exemplo, quando se fala sobre definição de retórica (2.15.22), status (3.6.13 e 3.6.38) e a respeito da proximidade das palavras de elogio e vitupério (3.7.25).

151 Popílio Lenas, citado duas vezes na Institutio $(10.7 .32 ; 11.3 .183)$, escreveu a respeito da compositio e da actio. 
nossa geração Virgínio ${ }^{152}$, Plínio ${ }^{153}$, Tutílio ${ }^{154}$. Há ainda hoje autores ilustres nesta área, que se tivessem abordado todos os aspectos do tema teriam me dispensado desta tarefa. Mas pouparei os nomes dos vivos: virá o tempo em que serão elogiados, pois seus méritos hão de passar à posteridade, a inveja não há de perdurar.

22.Mesmo depois de tantas e tão importantes autoridades não hesitarei em manifestar minha opinião sobre alguns pontos. Posto que não adotei alguma seita como se estivesse contagiado por uma espécie de superstição, e como foi ofertada copiosa matéria para que meus leitores escolhessem fazer o que quisessem, eu reúno em um único trabalho um extenso material, encontrado em muitos autores, e estou satisfeito de ter o esforço reconhecido onde nem sempre há lugar para demonstração do engenho.

152 Professor de retórica da época de Cláudio, teve como aluno o poeta Pérsio. Após a conspiração de Pisão, foi exilado por Nero (Tácito, Ann. 15.71). Ver também 4.1.23; 7.4.40; 11.3.126.

153 Plínio, o Velho. Sua obra sobre retórica - Studiosus - é mencionada por seu sobrinho (Ep. 3.5.5). Quintiliano faz crítica a Plínio, ao falar da actio (11.3.143-148).

154 Provável rétor citado por Marcial (5.56.6), quando o poeta faz uma lista de gramáticos e rétores a serem evitados. 


\section{CAPÍTULO 2}

[Origem da retórica]

1. A questão sobre a origem da retórica não deve tomar-nos muito tempo. Quem pode duvidar de que os homens, assim que nascem, recebem da própria natureza o dom da fala (esse é sem dúvida o princípio da linguagem), e que sua utilidade levou ao estudo e aperfeiçoamento, a teoria e o exercício, ao seu apogeu?

2. Não entendo por que alguns consideram que uma preocupação com o discursar teria começado quando pessoas que eram intimadas em algum processo judicial se empenharam em falar de forma mais elaborada para se defender. Este poderia ser o motivo mais honroso, mas não necessariamente o primeiro, sobretudo porque a acusação precede a defesa. A não ser que alguém alegue que a espada foi inventada por um homem que buscou o uso do ferro antes para sua defesa do que para atacar outros.

3. A natureza, portanto, propiciou o início da fala; a observação, o início da arte de falar ${ }^{155}$. Da mesma forma como na medicina os homens, vendo o que é saudável e o que é insalubre, desenvolveram uma arte seguindo essa observação, ao perceberem que no discursar umas coisas eram úteis, outras inúteis, anotavam o que cabia imitar e o que evitar, e acrescentaram eles próprios também alguns detalhes segundo uma

${ }^{155}$ Cf. Cícero, de Orat. 1.109. 
metodologia; toda essa matéria foi comprovada na prática. Então cada um pôs-se a ensinar o que sabia.

4. É bem verdade que Cícero'156 atribuía a origem da oratória aos fundadores das cidades e aos legisladores, que precisavam contar com o poder do discurso. Não entendo, porém, por que ele considera que esta seja a origem mais remota, quando até hoje existem povos nômades e sem cidades nem leis, e, mesmo assim, aqueles que nasceram nesses povos atuam como embaixadores, fazem acusações e defesas, e além do mais, alguns têm o crédito de falar melhor que outros.

156 Inv. 1.2. 


\section{CAPÍTULO 3}

[Partes da retórica]

1. Todo sistema oratório, segundo a maioria das autoridades - e as mais importantes -, consta de cinco partes157: invenção, disposição, elocução, Memória, proferimento ou atuação (pode-se dizer de ambas as formas). E todo discurso, pelo menos o que enuncia alguma intenção, necessariamente precisa conter um assunto e uma formulação.

2. Quando um discurso é breve e limitado a um único período158 pode ser que não exija nada além disso, mas quando é longo, ele requer muito mais. Pois não importa apenas o que e como dizemos, mas também em que lugar. Há, portanto, a necessidade também da disposição ${ }^{159}$. Porém não seríamos capazes de dizer tudo o que o assunto exige nem dispô-lo no lugar adequado se não fosse com a ajuda da memória, e é por isso que ela é a quarta parte.

3. Mas um proferimento inadequado, seja pela voz ou pela gesticulação, prejudica e quase destroi tudo isso: consequentemente é preciso colocar a atuação no quinto lugar.

\footnotetext{
157 A divisão em cinco partes está presente na Retórica a Herênio (1.3) e em Cícero, Inv. 1.9.

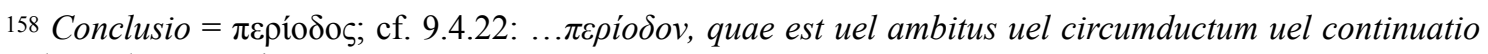
uel conclusio; também em 5.14.3; 8.2.22; 10.2,17.

159 Ver 7.1.2.
} 
4. E não se deve dar ouvidos a certas pessoas, entre as quais Albúcio ${ }^{160}$, que pretendem que haja apenas as três primeiras partes, uma vez que a memória e a atuação caberiam à natureza, não à arte (apresentarei as regras delas quando chegar o momento), apesar de que também Trasímaco ${ }^{161}$ pensou o mesmo sobre a atuação ${ }^{162}$.

5. Alguns acrescentaram a essas uma sexta parte163, atrelando à invenção um julgamento, porque primeiro viria a invenção, depois o juízo. Pessoalmente, não acredito que alguém possa nem mesmo ter encontrado algo sem ter feito um juízo prévio; pois não se diz que alguém encontrou contradições, generalidades e tolices, e sim que não as evitou.

6. É certo que na sua Retórica ${ }^{164}$ Cícero subordinou o julgamento à invenção, mas me parece que este procedimento é tão intrínseco às três primeiras partes (pois sem julgamento não haveria nem disposição nem elocução) que acredito que até o proferimento toma-lhe enormes empréstimos.

7. E me atrevo a dizê-lo porque nas Partições Oratórias ${ }^{165}$ Cícero chegou às mesmas cinco partes acima mencionadas. Efetivamente, depois de fazer num primeiro momento uma divisão em duas partes — invenção e

160 Caio Albúcio Silo, orador, declamador e professor de retórica na época de Augusto (Suetônio, Gram.e Rhet. 30). Ver 2.15.16 e 3.6.62.

${ }^{161}$ Professor de retórica em Atenas (séc. IV).

162 Igualmente Aristóteles, $R h .1404$ a 15.

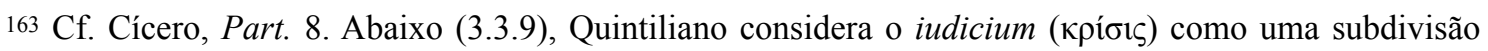
que Hermágoras faz de oikovouía. Ver Kennedy (1963), p. 314.

164 Aqui não se trata do Da Invenção; pode ser Partições oratórias 8; ou Orador 44.48.

165 Part. 3. 
elocução - , ele atribuiu o assunto e a disposição à invenção, à elocução a formulação e o proferimento, e estabeleceu uma quinta parte como uma espécie de guardiã comum de todas as outras: a memória ${ }^{166}$. Igualmente no Orador 167 ele disse que a eloquência consta de cinco elementos, nesse trabalho posterior seu posicionamento é mais preciso.

8. Parecem-me igualmente ávidos por alguma novidade aqueles que acrescentaram o arranjo depois de mencionar a disposição. Como se a disposição fosse outra coisa que não o arranjo da matéria na melhor ordem possível! Dion ${ }^{168}$ ensinava somente a invenção e a disposição, mas ambas dividiam-se duplamente, em assunto e em formulação, de modo que a elocução seja [parte] da invenção, e o proferimento [parte] da disposição, sendo-lhes acrescentada como quinta parte a memória. Os teodorianos, em geral, dividem a invenção em duas: assunto e elocução, e depois seguem-se as outras três partes.

9. Hermágoras subordinou o julgamento, a partição e o arranjo e outras partes da elocução à oỉkovouía [“administração/ordenação”], termo grego que expressa a gerência de assuntos domésticos, aqui usado por catacrese ${ }^{169}$, não há equivalente em latim.

\footnotetext{
$166 \mathrm{O}$ termo custos para a memória aparece também na Retórica a Herênio (3.28).

${ }^{167}$ Orat. 43 e $54-55$.

168 Rétor desconhecido.

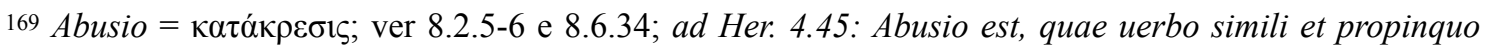
pro certo et proprio abutitur, hoc modo: Vires hominie breues sunt, etc. Ver também Cícero, de orat. 3.169; Orat, 94.
} 
10.Surge então uma questão, porque, na ordem das partes, uns fizeram seguir a memória à invenção, outros à disposição. Na minha opinião, o mais adequado é que ela venha em quarto lugar, pois devemos não apenas reter o que se descobriu, para dispor numa ordem e, uma vez disposto, expressá-lo em palavras, mas também confiar à memória as ideias que elaboramos com as palavras, pois ela guarda tudo o que foi reunido para o discurso.

11.Ademais, não foram poucos os que adotaram a interpretação de que essas não são partes da retórica e sim tarefas do orador ${ }^{170}$, pois cabe a ele encontrar, dispor, expressar etc. Se aceitarmos essa ideia, não deixaremos nada para a arte.

12.Efetivamente, cabe ao orador discursar bem, mas a ciência de discursar bem será a retórica ${ }^{171}$; ou ainda — como consideram outros — persuadir é função do artífice, mas o poder de persuadir é da arte. Sendo assim, encontrar e dispor certamente é tarefa do orador, mas a invenção e a disposição podem ser vistas como próprias da retórica.

13.Muitos discordaram neste ponto: seriam essas partes ou tarefas da retórica ${ }^{172}$ ? Ou ainda, segundo Ateneu ${ }^{173}$, elementos (que os gregos chamavam de $\sigma \tau o \imath \chi \varepsilon \tilde{\imath} \alpha)$ ? Mas não seria correto chamá-las "elementos",

170 Embora a expressão usual fosse officia oratoris, aqui Quintiliano emprega opera oratoris, uma

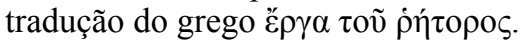

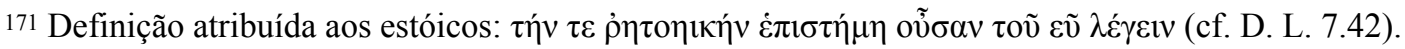

172 Opera rhetorices, aqui - diferentemente de opera oratoris (3.3.11) - o termo significaria "produtos". Segundo Taylor (1971) p.113, Quintiliano entende que as partes da retórica não são resultado de algo, mas o que produz algo.

173 Ver 3.1.16. 
pois desse modo seriam apenas princípios básicos, como no universo são a umidade, o fogo, a matéria ou os corpos indivisíveis. Igualmente incorreto seria denominá-las "tarefas", porque não são realizadas por outros, mas elas mesmas realizam alguma coisa; portanto são "partes".

14.E já que a retórica está constituída por elas, como o todo se constitui de partes, é impossível que estas sejam do todo as partes das quais ele se constitui. Parece-me que os escritores que as denominaram "tarefas", movidos também pelo fato de que, numa outra divisão [da retórica], não queriam incidir no mesmo nome, eles chamavam "partes da Retórica" a laudativa, a deliberativa e a judicial. Mas se essas são partes, são antes partes da matéria do que da arte.

15.Sem dúvida, em cada uma delas está presente a retórica como um todo, uma vez que cada uma requer a invenção, a disposição, a elocução, a memória e o proferimento. Sendo assim, alguns autores preferiram chamá-las "os três gêneros da retórica", mas a melhor classificação foi daqueles que Cícero seguiu, denominando-as "gêneros de causas"174.

174 Cf. Cícero, Inv. 1.12; Part. 70, Top. 91, de Orat. 1.141. 


\section{CAPÍTULO 4}

[Os gêneros de causa]

1. Ora, algo que se discute é se são três ou mais os gêneros [das causas]. Não há dúvida, porém, que quase todos os escritores, e particularmente os de reconhecida autoridade entre os antigos, estavam satisfeitos com essa divisão e seguiram Aristóteles, que apenas empregou outro termo: "concional"175 em lugar de "deliberativo".

2. Porém, houve ligeira tentativa, tanto naquela época, por parte de alguns autores gregos, e de Cícero (nos livros Do Orador) ${ }^{176}$; como atualmente, quando prevalece a ideia - promovida pela maior autoridade de nossos dias ${ }^{177}$ — de que existe não apenas mais de três gêneros, como também que eles seriam praticamente inumeráveis.

3. Ora, se pusermos a tarefa de louvar e vituperar na terceira parte ${ }^{178}$, de que gênero pareceremos participar quando nos queixamos, consolamos, apaziguamos, incitamos, aterrorizamos, demonstramos, preceituamos, interpretamos falas obscuras, narramos, imploramos, agradecemos, felicitamos, repreendemos, imprecamos, descrevemos, damos instrução,

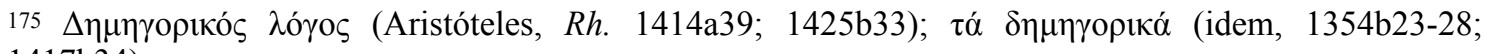
1417b34).

176 Esses autores são desconhecidos; Cícero, de Orat. 2.43-71.

177 Certamente um contemporâneo de Quintiliano, geralmente considerada referência a Plínio, o Velho (ver 3.1.21 acima). Ver Cousin, p. 151, nota 4.

178 I.e., o genus causae que se segue depois do iudiciale e do deliberativum.
} 
relatamos, expressamos um desejo, damos nossa opinião, e muito mais? 179

4. É como se eu, para permanecer naquele antigo ponto de vista, tivesse que pedir permissão e ainda procurar saber por que motivo os pioneiros no assunto restringiram a um campo tão limitado um material tão vasto. Os que julgam que eles estavam errados, acreditam que eles seguiram tal divisão por verem os oradores de então ocupar-se quase unicamente desses três.

5. Realmente, escreviam-se discursos de elogio e de vitupério, e era

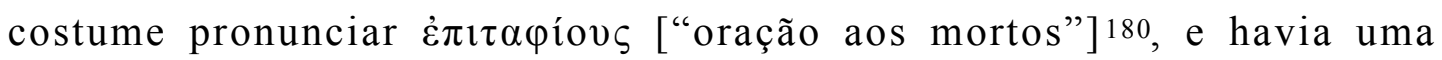
dedicação maior nas deliberações e julgamentos, consequentemente os escritores de manuais circunscreveram como algo exclusivo o que era mais frequente.

6. Os que defendem esse ponto de vista, no entanto, estabelecem três tipos de ouvintes: o primeiro é o dos que se reúnem tendo em vista o deleite, o segundo, dos que recebem conselhos, o terceiro[tipo], [é] o dos julgam as causas ${ }^{181}$. Investigando tudo isso, ocorre-me também a seguinte ideia: toda função de um discurso encontra-se nos tribunais ou fora deles.

\footnotetext{
179 Enumeração de ações mencionadas por autores anteriores, com destaque para Cícero: de Orat. 2.50: consolamur; obiurgamus; 2.64; 3.205: deprecamur; describimus; renuntiamus, optamus.

180 Dentre elas a mais antiga oração fúnebre é a de Péricles, relatada por Tucídides (2. 34-46). Ver Cousin, nota complementar 1, p. 152.

181 Aristóteles, Rh. 1.1358 a36 ss. Cícero, Part. 10.
} 
7. É evidente o gênero do que se investiga mediante julgamento. O que não se submete a um juiz concerne ao passado ou ao futuro: louvamos ou vituperamos o que é passado, deliberamos sobre o futuro.

8. Na mesma linha, todas as coisas sobre as quais é preciso falar são necessariamente certas ou incertas. As coisas certas são enaltecidas ou criticadas, segundo a inclinação de cada um. Quanto às incertas, em parte somos livres para escolher e então ocorre uma deliberação; em parte, são submetidas a um veredicto alheio, e, então, tem-se um litígio.

9. Anaxímenes ${ }^{182}$ propôs a existência de dois tipos gerais, o discurso judicial e o concional, e sete espécies: exortação, dissuasão, louvor,

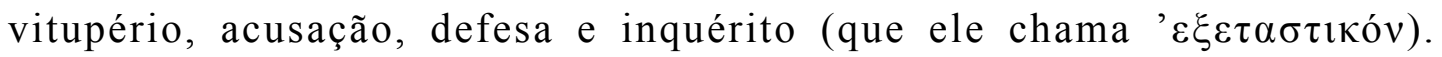
Dessas, as duas primeiras seriam partes do gênero deliberativo; oas duas seguintes do demonstrativo; e as três últimas, do judicial.

10.Menciono Protágoras ${ }^{183} \mathrm{de}$ passagem. Ele considera haver somente quatro tipos: interrogação, resposta, ordem e súplica (que ele chamou $\varepsilon \hat{\chi} \chi \omega \lambda \eta ́)$. Platão, no Sofista ${ }^{184}$, acrescentou aos discursos judicial e popular um terceiro tipo: $\pi \rho \circ \sigma o \mu \imath \lambda \eta \tau \imath \kappa o ́ v$, que poderíamos muito bem nos permitir chamar "conversacional" — é distinto do forense,

\footnotetext{
182 Anaxímenes de Lâmpsaco, historiador e rétor, floresceu na segunda metade do século IV a.C, foi professor, de Alexandre o Grande, o que faz com que seja tido como autor da Retórica a Alexandre. Ver Kennedy (1963) pp. 114-124.

183 Sobre Protágoras ver 3.1.10 acima. Diógenes Laércio (9.53-54) relata que Protágoras foi a primeiro a

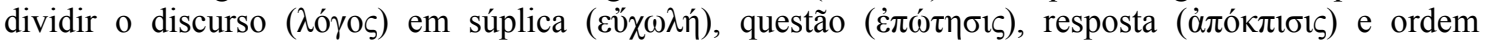

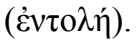

184 Sph. 222c.
} 
adequando-se a discussões privadas. Sua natureza é quase a mesma da dialética.

11.Isócrates ${ }^{185}$ considerava haver em todo gênero elogio e vitupério.

12.Para mim, o mais seguro é seguir a maioria das autoridades, e isso é a razão parece ditar. Existe, então, como disse, um gênero único que abarca tanto o elogio como o vitupério, da melhor parte deriva sseu nome: "laudativo". Outros o denominam "demonstrativo"186. Acredita-se que tanto um como o outro termo derivam do grego, pois o chamam $\dot{\varepsilon} \gamma \kappa \omega \mu \imath \alpha \sigma \tau \imath \kappa o ́ v$ [encomiástico] ou $\dot{\varepsilon} \pi \imath \varepsilon \imath \imath \tau \imath$ Kóv [epidíctico].

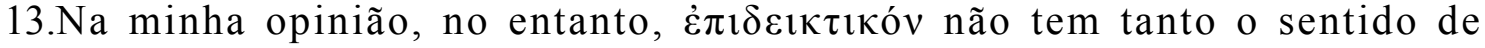
"demonstração" quanto o de "exibição", distanciando-se muito do significado de $\dot{\varepsilon} \gamma \kappa \omega \mu \imath \alpha \sigma \tau \imath \kappa o ́ v$, pois, embora contenha em si o gênero laudativo, não se restringe somente a este.

14.E acaso alguém poderia negar que os panegíricos são discursos epidícticos? Ainda assim têm o formato de um discurso exortativo e, na maioria das vezes, tratam de interesses da Grécia. Assim, é bem verdade que são três os tipos de causas, mas eles concernem ora a questões práticas, ora a uma exibição. A não ser que acaso o termo "demonstrativo" não seja empregado como tradução do grego, mas

185 Provavelmente a mesma obra a que Quintiliano faz referência em 3.5.18 abaixo.

186 Cf. Cícero, Inv. 1.7; ad Her. 1.2, etc. Quintiliano também opta por demonstratiuum: 5.10.45; 8 pr.6; 8; 9.4.130; 11.1.48. 
porque um elogio e um vitupério demonstram a natureza do que quer que seja.

15.0 segundo gênero é o deliberativo; o terceiro, o judicial. Todas as demais espécies incluem-se nestes três gêneros. E dentre elas não se encontrará nenhuma em que não seja preciso louvar ou vituperar, persuadir ou dissuadir, impetrar uma ação ou repeli-la. São comuns a todos os gêneros também o cativar, narrar, demonstrar, amplificar, atenuar, moldar os ânimos dos ouvintes, excitando ou apaziguando seus afetos.

16.Eu não concordaria nem mesmo com os que consideram que a matéria do laudativo se restringe ao honroso; a do deliberativo, ao útil; a do judicial, ao justo ${ }^{187}$, fazendo uso de uma divisão que tem mais de brevidade e de elegância do que de exatidão ${ }^{188}$. Pois, de uma certa maneira, todos os gêneros se apoiam mutuamente: também no elogio se fala de justiça e utilidade; nas deliberações, de honestidade; e raramente se pode encontrar numa causa judicial que não apresente em alguma de suas partes algo do que mencionei acima.

\footnotetext{
187 Aristóteles, Rh.1. 1358 b20 ss.; Cícero, Inv. 2.4.

188 Aqui Quintiliano discorda de Cícero (cf. de Orat. 1.141; Part. 71, 83, 98; Top. 91) que, por sua vez,

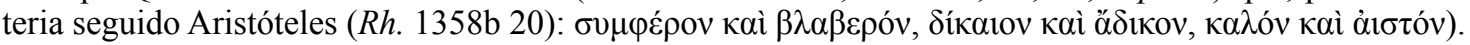




\section{CAPÍTULO 5}

[De modo geral em que consiste o método de discursar]

1. Todo discurso é composto pelo que é significado e pelo que significa, ou seja, conceitos e palavras. A faculdade de discursar é aperfeiçoada com ajuda da natureza, da arte e do exercício ${ }^{189}$. Alguns acrescentam ainda um quarto fator: a imitação190, que eu atrelo à arte.

2. Da mesma maneira, três são os objetivos que o orador deve ter em mente: ensinar, comover e deleitar191. Esta divisão é mais clara do que a de certos rétores, que dividem toda atividade oratória em conceitos e afetos. Estas duas partes nem sempre se ajustarão à matéria a ser tratada, pois haverá determinadas situações desprovidas de afetos e, embora estes não tenham lugar em toda parte, ainda assim são extremamente efetivos onde quer que apareçam no discurso.

3. Entre os autores mais eminentes há um consenso de que em retórica determinadas coisas exigem comprovação, outras não. Eu concordo com eles. Outros, no entanto, como Celso, opinam que o orador não deve tratar de nada além do que está sob investigação. Está em desacordo com essa interpretação não só a maioria dos autores, mas sobretudo a própria divisão da retórica é contrária a isso, a não ser que não fosse

\footnotetext{
189 Tríade frequente entre os autores antigos: Aristóteles (D. L. 5.18), Platão (Phdr. 269d), Isócrates (Contra os sofistas (13) 14-19; Antidosis (15), 187), Cícero (de Orat. 1.14-15; 2.112 232; Arch. 1; Cael. 19.45; Inv 1.5), Tácito (Dial. 33.5), etc.

190 Cf 10.2.1; ad Her. 1.3.

191 Provavelmente sob influência de Aristóteles, Cícero (de Orat. 2.115, 121, 128; Brut. 185, 276) retoma as três tarefas do orador e é seguido por Quintiliano (cf. 8 proêmio 7, 12.10.59).
} 
dever do orador louvar as coisas que seguramente são honrosas e vituperar as que reconhecidamente são torpes.

4. Com certeza todos concordam em um ponto: as questões se apoiam ou em algo escrito ou em algo não escrito. As primeiras são questões de direito; as outras, questões de fato. Hermágoras ${ }^{192}$ e seus discípulos chamam o primeiro gênero "legal", o segundo, "racional", ou seja,

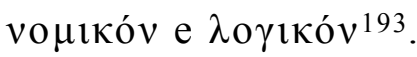

5. Mesma interpretação tiveram os que diziam que toda questão se apoia em fatos ou palavras. Igualmente concordaram que as questões ou são indefinidas ou definidas. Indefinidas são aquelas que, de ambas as partes, tratam de um tema sem referências específicas a pessoas, épocas, lugares e outros pontos semelhantes. Os gregos chamam "tese"; Cícero, "proposição"194; alguns, "questões públicas universais"; outros, "questões convenientes a um filósofo"195. Ateneu as denomina-a "parte da causa”.

6. Cícero faz uma diferenciação do gênero de questão indefinido entre conhecimento e ação ${ }^{196}$. Por exemplo, é de conhecimento "se o mundo é governado pela Providência"; de ação "se é preciso participar na

\footnotetext{
192 Fragmento 12a Mathes.

${ }^{193}$ A divisão racional/legal está relacionada ao sistema de status no capitulo 6. No gênero racional estão a conjectura, a definição e a qualidade; no legal: o escrito e a intenção, a ambiguidade e leis contraditórias.

194 Part. 9.61,68; Top. 79,80,86,90. Cícero emprega também o termo consultatio : Part. 4, 67, 106; de Orat. 3.111.

195 Cf Hermógenes., 25.5.

196 Ou "especulação" e "pragmatismo". O que faz uma aproximação à análise de Hermógenes (25.5) sobre as quaestiones philosopho conuenientes e as quaestiones ciuiles.
} 
administração pública". O primeiro gênero tem três aspectos: “é ou não", "o que é" e "qual a sua natureza", pois todos os três podem ser desconhecidos. O segundo gênero tem dois aspectos: "de que modo o obtemos [o cargo]" e "como o utilizamos".

7. As questões definidas, por sua vez, surgem de uma relação entre fatos, pessoas, épocas e etc. Estas são denominadas "hipóteses" pelos gregos; por nós, em latim, “causas". Neste caso, parece que toda questão definida gira em torno de coisas e pessoas.

8. A indefinida é sempre mais abrangente, pois é dela que deriva a definida. Isto fica mais claro com um exemplo197: é uma questão indefinida "deve-se casar?"; definida, "Catão deve se casar?", e por isso pode ser uma suasória. Também questões que não envolvem pessoas específicas costumam referir a algo específico. Assim, a questão geral 198 seria: “deve-se participar na administração pública?” Mas há referência a algo específico quando se pergunta: “deve-se participar de um governo tirânico?"199

9. Neste último caso subentende-se uma pessoa oculta, por assim dizer, pois o tirano gera uma questão dupla e subentendem-se indicações implícitas tanto de tempo como de qualidade; ainda assim não se pode denominá-la propriamente "causa". Estas questões que chamo

\footnotetext{
197 A questão da necessidade de casar-se aparece em Hermógenes (24.8), quando fala da tese.

198 Simplex = "geral", uma questão direta, sem implicações.

199 Tema abordado por Cícero ao tratar de declamações privadas em Att. 9.4.
} 
“indefinidas" são também denominadas "questões gerais". E se esta denominação é correta, as questões "definidas" são "específicas”. De qualquer maneira, em toda questão específica se inclui uma geral, já que o gênero é anterior à espécie 200 .

10. Ademais, talvez nas causas tudo o que incide na questão de qualidade seja do tipo geral. "Milão matou Clódio. Foi justo matar quem lhe armou uma emboscada"? Neste caso não se pergunta: "é justo matar quem arma uma emboscada"? E as conjecturas? Não seriam questões gerais coisas deste tipo: "é motivo para cometer um crime o ódio ou a cobiça"?, "deve-se acreditar em confissões obtidas sob tortura"?, "deve-se confiar mais nas testemunhas do que nos argumentos"? Pois é certo que na definição está compreendido tudo que é universal.

11.Alguns consideram que também as questões que se referem a pessoas e causas podem por vezes serem chamadas $\theta \dot{\varepsilon} \sigma \varepsilon \imath \varsigma$ [teses], desde que apresentadas de um modo diferente. Por exemplo: seria uma causa quando Orestes é acusado; uma tese, se Orestes foi absolvido com justiça 201. É desse mesmo gênero a seguinte questão: "Foi correto Catão entregar Márcia a Hortênsio?"202 Esses rétores distiguem a tese da causa explicando aquela como teórica e esta como prática. Na primeira

\footnotetext{
200 Para Quintiliano a tese (prior) pressupõe uma hipótese (cf. 3.5.5; 3.5.15), ou seja, ele entende a tese como genus e a hipótese como species. Ver Taylor (1971) pp. 156-159.

201 Ver 3.11.4.

202 Cícero. Inv. 1.18-19. Catão divorciou-se de Márcia para que ela se casasse com Hortênsio, que anteriormente quis que a filha de Catão, Pórcia, se divorciasse de Bíbulo para casar-se com ele. Márcia voltou para Catão após a morte de Hortênsio. (cf. Plutarco. Cat. Mi., 25).
} 
discute-se apenas para conhecer a verdade; na segunda há um assunto particular a ser resolvido.

12.Alguns, entretanto, consideram que as questões universais não têm utilidade para o orador, porque de nada serve determinar se é preciso casar-se ou participar na administração pública, se a idade ou a saúde o impede de fazê-lo. Mas nem todos esses tipos de questões podem ser alvo de objeção, como, por exemplo, estas: "a virtude é um fim em si mesma?", “o mundo é governado pela Providência?”

13.Além disso, também nas questões que se referem a pessoas, da mesma maneira que não basta tratar da questão geral, não se pode delimitar a específica sem antes examinar qual é a geral. De fato, como Catão poderá decidir se deve casar sem antes estar definido que é preciso casar-se? E como se questionará se ele deve casar-se com Márcia sem antes saber que Catão tem que casar-se?

14.Existem, no entanto, livros atribuídos a Hermágoras que corroboram esta opinião. Quer se trate de um título falso, quer obra de outro Hermágoras $^{203}$. Pois como poderiam ser desse mesmo autor, que escreveu muitas coisas admiráveis sobre a arte retórica e, como fica claro também no primeiro livro sobre retórica de Cícero ${ }^{204}$, dividiu a matéria da retórica em teses e causas? Cícero critica essa divisão

\footnotetext{
203 Sobre a identidade dos Hermágoras, ver Matthes Fragmento 6b.

204 Inv. 1.8 .
} 
defendendo que a tese nada tem a ver com o orador e relacionando todo esse gênero de questões aos filósofos.

15. Contudo, ele me livrou do constrangimento de ter que responder a isso, tanto porque ele mesmo rejeita essa obra205, como porque, no Orador e nos livros que escreveu Sobre o orador e nos Tópicos ${ }^{206}$, ele preceitua que separemos a controvérsia de pessoas e circunstâncias específicas, uma vez que é possível falar mais amplamente do geral do que do específico, e porque o que é comprovado no geral, necessariamente é comprovado no particular.

16. Os status que ocorrem neste tipo de matéria como um todo são os mesmos das causas ${ }^{207}$. Acrescenta-se a isso a ocorrência de questões baseadas nos fatos em si e questões que se referem a algo concreto 208 . No primeiro caso, "deve-se casar?"; no segundo caso, "um velho deve casar?". Ou, no primeiro, "é corajoso?"; no segundo, “é o mais corajoso?", e assim por diante.

17. Apolodoro define uma causa (para usar a tradução de seu discípulo Válgio ${ }^{209}$ ), assim: “causa é um negócio que está voltado em todos seus aspectos para uma questão"; ou: "causa é um fato cujo fim é a controvérsia". Depois ele definiu propriamente fato, da seguinte

\footnotetext{
205 de Orat. 1.5.

206 Orat. 45; de Oratore 2.133 ss.; 3.120; Top. 86.

207 Cícero, de Orat. 3.113; Part. 62.

208 Alusão às questões “simples" e a “que têm referência a algo concreto", apresentadas em 3.5.8-9.

209 Mencionado em 3.1.18.
} 
maneira: "fato210 é uma combinação de pessoas, lugares, épocas, motivos, meios, incidentes, ações, instrumentos, falas, evidências escritas e não escritas".

18. Entendamos agora a causa como vi ó $\theta \varepsilon \sigma i \varsigma$ [hipótese] e caso como $\pi \varepsilon \rho i ́ \sigma \tau \alpha \sigma \imath \varsigma$ [perístase]. Mas alguns definem a causa em si da mesma forma como Apolodoro define fato. Isócrates211, por sua vez, diz que a causa é uma questão definida de caráter público, ou uma controvérsia que envolve pessoas definidas. Cícero212 usa estas palavras: "uma causa se reconhece em pessoas, lugares, épocas, ações e circunstâncias determinados, quer em todos ou em sua maioria”.

\footnotetext{
210 Enquanto o termo $\pi \varepsilon \rho i ́ \sigma \tau \alpha \sigma ı \varsigma$ em Hermágoras é traduzido por Válgio como negotium, Quintiliano o traduz por circumstantia (5.10.104).

211 Texto desconhecido.

212 Top. 80.
} 


\section{CAPÍTULO 6}

[O que é o estado da causa]

1. Então, uma vez que toda causa reside em algum status (estado de causa), antes de começar a falar de que modo se deve tratar cada gênero de causa é preciso, a meu ver, examinar o que é comum a todas: o que é o status, donde surge, quantos e quais são. Ainda que alguns considerem que o estado de causa diga respeito somente à matéria judicial ${ }^{213}$, sua ignorância ficará evidente pelos próprios fatos, depois que eu tiver falado sobre os três gêneros ${ }^{214}$.

2. O que nós chamamos status (estado da causa), alguns denominam "constituição"215; outros, "questão"; outros, ainda, "aquilo que surge a

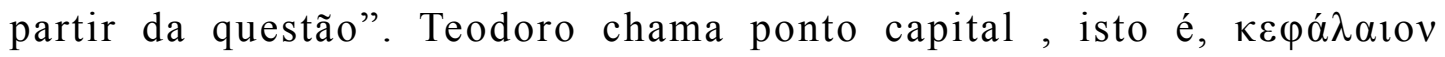

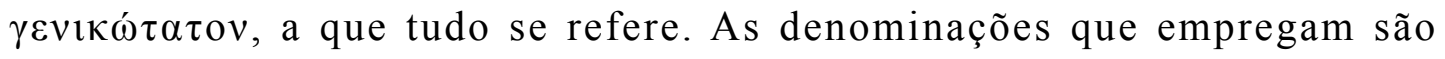
diversas, mas o sentido é o mesmo, e não importa para quem está aprendendo com que nome cada coisa é chamada, contanto que a coisa em si esteja clara.

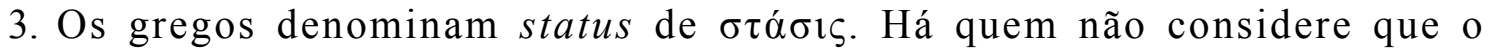
termo foi inventado por Hermágoras ${ }^{216}$, mas alguns o atribuem a

\footnotetext{
213 A Retórica a Herênio (1.18-25) é um exemplo de tratados que relacionaram a teoria dos status apenas à oratória judicial.

214 O demonstrativo no capítulo 7, o deliberativo no capítulo 8 e o judicial nos capítulos 9 a 11 . Nos livros seguintes dedicados à invenção e disposição (livros 4 ao 7) Quintiliano discorre predominantemente sobre o gênero judicial, embora faça referências aos outros dois gêneros.

215 Cícero, Inv. 1.14-19.

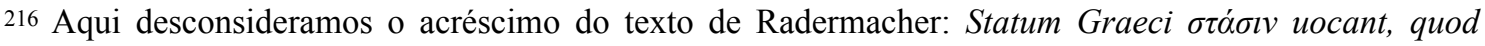
nomen non <nulli> primum ab Hermagora. Cf. edição "Les Belles Lettres".
} 
Náucrates ${ }^{217}$, discípulo de Isócrates; outros, a Zópiro ${ }^{218}$ de Clazômenas; ainda que pareça que Ésquines 219 também tenha empregado este termo em um discurso contra Ctesifonte, ao pedir aos juízes que não permitissem a Demóstenes divagar, e sim que o obrigassem a falar sobre o estado da causa propriamente.

4. Dizem que esta nomenclatura vem do fato de que no status se encontra o primeiro embate da causa, ou de que a causa baseia-se nele. Eis a origem do termo; agora mostraremos o que é. Alguns disseram que o status é o primeiro conflito das causas ${ }^{220}$, penso que seu entendimento é correto, mas a formulação é insuficiente.

5. De fato o status não é a primeira contestação do tipo "fizeste", "não fiz", mas sim aquilo que se origina nessa primeira contestação, isto é, o tipo de questão: “fizeste","não fiz","acaso ele fez?"; "fizeste isto", “não fiz isto","o que ele fez?". Com isso fica evidente que o primeiro deve ser investigado pela conjectura e o segundo pela definição; como ambas as partes apoiam-se nisso, a questão será de status conjectural ou de definição.

6. Por exemplo, se alguém disser: "som é o choque entre dois corpos", está equivocado, a meu entender, pois o som não é um choque, mas a

217 Ver Cícero, Orat. 172, de Orat. 3.173.

218 Em Diógenes Laércio (9.114) há menção de um orador chamado Zópiro, contemporâneo do filósofo cético Timão de Filos (320-230 a.C.).

219 Jean Cousin (p.161 nota 1) explica que Quintiliano se equivoca ao mencionar Ésquines, porque em seu

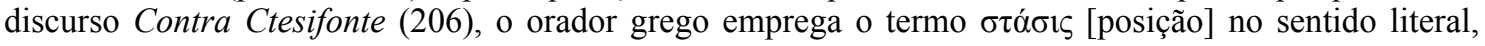
sem o significado técnico retórico (cf. Calboli Montefusco, 1986, nota 2, p.1).

220 Cícero, Inv. 1.10 . 
consequência do choque. Porém, isso não tem tanta importância, já que, de qualquer maneira, se entende o que foi falado. Mas pode ocorrer um grande erro, oriundo de uma má interpretação: entendendo o fato como a primeira contestação, concluíram que o status deve sempre derivar da primeira questão, o que é um enorme engano.

7. Não há questão que não apresente necessariamente um status (posto que ela se constitui de uma acusação e uma defesa), mas algumas são inerentes às causas sobre as quais é preciso se pronunciar, ao passo que outras são trazidas de fora da causa, mas contribuem com algo para toda a argumentação, como uma espécie de tropa auxiliar221. Daí sucede que se diga haver várias questóes em uma única controvérsia.

8. Dentre elas, muitas vezes desenvolve-se em primeiro lugar o que é menos importante. Então ocorre com frequência o seguinte: depois de tratá-los, deixamos de lado os pontos que não nos inspiram tanta confiança, às vezes contentando-nos de oferecê-los espontaneamente ao adversário, outras vezes satisfeitos por usá-los como um degrau para os aspectos mais efetivos.

9. A causa simples, por sua vez, mesmo se é defendida de várias formas, não pode apresentar mais de um único ponto sobre o qual se vai julgar, e, consequentemente, esse será o seu estado de causa, uma vez que o orador entende dever demonstrar e o juiz atentar particularmente a ele, pois é nele que a causa se baseará.

${ }^{221}$ Em 7.1.19-37, Quintiliano fornece uma série de exemplos sobra as questões adductae. 
10.Além disso, pode haver vários status para as questões. Para deixá-lo claro com um brevíssimo exemplo: o réu declara "ainda que o tenha feito, o teria feito dentro da lei", ele está empregando o status de qualidade; quando acrescenta: “mas eu não fiz,” ele está se valendo da conjectura. Porém, é sempre mais seguro não ter praticado o delito, por isso vou considerar que o status consiste naquilo que eu diria, se não pudesse apresentar mais do que um único ponto.

11. Consequentemente, estava correta a denominação de primeiro conflito das causas e não das questões. Na primeira parte da defesa de Rabírio Póstumo222, Cícero assume a posição de negar que uma acusação possa ser feita contra um cavaleiro romano; na segunda parte, a de afirmar que seu cliente não recebeu nenhum pagamento em dinheiro. Eu diria, porém, que o status residia no ponto mais eficaz.

12.E ainda no processo de Milão eu não consideraria que a causa se configurou em torno das primeiras questões, que foram apresentadas antes do proêmio 223 , e sim quando se mostrou com toda ênfase que Clódio armou uma emboscada e por isso foi morto legitimamente. Aquilo que o orador deve ter em mente antes de tudo, ainda que tenha que tratar de vários outros pontos em defesa de sua causa, é o que ele

\footnotetext{
222 Cícero alegou (12-19) que o caso de Rabírio não se enquadrava na lex Iulia de repetendis, pois ela tratava sobretudo de magistrados pertencentes à nobilitas.

223 Na Institutio Oratoria (4.2.25) estão enumeradas três quaestiones: seria impossível defender um acusado que confessa ter matado um homem?; Milão já haveria sido anteriormente condenado pelo senado?; Pompeu estaria contra Milão, ordenando, entre outras coisas, cercar o tribunal com soldados armados? E Quintiliano assim conclui o parágrafo: ergo hae quoque quaestiones uim prooemii obtinebant, cum omnes iudicem praeparent. No Defesa de Milão, no entanto, estas questões são apresentadas depois do proêmio (7-22), o que nos leva a identificar aqui um equívoco de Quintiliano. Muito provavelmente o erro é de origem textual (ver Cousin, nota complementar VI, 12 p. 267).
} 
quer deixar mais claro ao juiz. Porém não é pelo fato de que deva ser considerado em primeiro lugar que terá necessariamente de ser apresentado em primeiro lugar .

13.Outros atribuíram o status à primeira intervenção da defesa 224 . Cícero compartilha dessa opinião, com as seguintes palavras: "aquele argumento em que primeiramente a defesa se apoia como se estivesse preparada para oferecer resistência" 225 . O que, por outro lado, apresenta outra questão: saber se é sempre a defesa que define o status. É sobretudo Cornélio Celso ${ }^{226}$ quem se opõe a essa ideia, dizendo que o estado da causa não deriva da refutação da acusação, e sim daquele que confirma sua proposição. Desse modo, se o réu negar ter matado alguém, o status será definido pela acusação, que quer provar o contrário. Se o réu disser que o matou com justiça, a necessidade de prova passa de um para outro e cabe a ele expor sua versão.

14.Discordo inteiramente disso, pois é mais próximo da verdade o que se diz em sentido contrário. Não há litígio se o defensor não responder nada, consequentemente o status é definido pela defesa.

15.Minha opinião, no entanto, é que o status pode variar, e se apresenta conforme as circunstâncias das causas. Porque, algumas vezes, nas causas conjecturais pode ocorrer de a acusação definir o status.

\footnotetext{
224 Ad Her. 1.18: constitutio est prima deprecatio defensoris cum accusatoris insimulatione coniuncta; Cícero, Inv. 1. 13.

225 Top. 93.

226 Ver 3.1.21.
} 
(Efetivamente a conjectura é mais usada por aquele que acusa, e por isso alguns, sensibilizados com o réu, denominaram-no status de negação227). Mas também no caso de silogismo, toda a argumentação é apresentada por aquele que intenta o processo 228.

16.Mas, pelo fato de que, também em tal caso, aquele que nega parece tornar necessário fazer valer esses estados de causa, (pois se o réu disser "não fiz" obrigará o adversário a usar a conjectura, e se disser "não tens uma lei para este caso", o silogismo), concedamos que o estado de causa se origine na defesa. Mesmo assim, é possível que a definição do status seja alternada: às vezes é feita por quem acusa, outras vezes, por quem é acusado.

17.Considere-se, então, que seja esta a alegação do acusador: "mataste o homem". Se o réu negar, a defesa estabelecerá o status. E se ele confessar alegando que matou legitimamente um adúltero? Existe uma lei que o permite, naturalmente. Se a acusação não responder nada, não há litígio. Mas quando o acusador declara:"Não houve adultério", consequentemente a refutação passa a ser do acusador, e isso constituirá um status. Nesse caso o status surgirá a partir da primeira refutação, mas esta será feita pela acusação, e não pelo réu.

18.E quanto ao fato de que uma mesma questão pode tornar uma mesma pessoa ou o acusador ou o réu? "A quem exerceu a função de ator é

227 Cícero, Top. 92.

228 Ad Her. 1.23; 2.18; Cícero, Inv. 2. 148-149. 
proibido sentar-se nas catorze primeiras fileiras". Aquele que se apresentou no jardim para o pretor e que não esteve publicamente em cena senta-se no espaço das catorze primeiras fileiras ${ }^{229}$.

19.Há, de fato, a acusação: "exerceste a função de ator"; a refutação: "não exerci a função de ator"; a questão é: “em que consiste exercer a função de ator?" Se ele for acusado de violar um regulamento do teatro, a refutação virá do réu; se tiver sido expulso do espetáculo e mover uma ação por injúria, a refutação virá do acusador.

20.É mais comum, porém, que ocorra aquilo que é descrito pela maioria dos autores. Alguns evitaram esses problemas quando disseram que o status é o que se torna evidente a partir da acusação e da defesa, como, por exemplo: "fizeste", "não fiz" ou "fiz dentro da lei".

21.Vejamos, porém, se isso é o status ou se o status encontra-se neste ponto. Hermágoras ${ }^{230}$ chama status aquilo que permite entender o fato em questão e com o qual também as provas de ambas partes têm relação. Nossa opinião sempre foi esta: uma vez que é comum haver, numa mesma causa, diferentes status de questões, eu acredito que o estado da causa é o que há de mais importante nela e sobre o qual o caso mais versa. Se alguém preferir chamar de "questão geral" ou "ponto capital

\footnotetext{
229 A Lex Roscia theatralis (revogada por Sila e provavelmente restaurada pelo tribuno Róscio Otho em 67 a. C.) determinou lugares reservados especialmente para membros da ordem equestre: as 14 primeiras fileiras atrás do senado, em frente à orquestra. (Cf. Cícero, Mur. 40; Phil. 2.44).

230 Cf. Fragmenta 10a Matthes. Jean Cousin (nota 1, p.166) observa, no entanto, não reconhecer uma ideia hermagoreana nos grupos de palavras: et ad quem - referantur, posto que o rétor grego ensina que os argumentos das duas partes são extraídos da iudicatio, não do status causae.
} 
geral" 231, não vejo motivo para discussão, e menos ainda se alguém encontrar algum outro termo que passe a mesma ideia, mesmo que saiba, pela quantidade de publicações, que muitos autores se envolveram nesta discussão. Fico satisfeito em denominá-lo status.

22.Da mesma forma como há um imenso desentendimento entre autores não só nos outros assuntos, mas sobretudo neste me parece ter havido uma sede de aportar opiniões diversas. A tal ponto que não há um acordo de quantos são e quais denominações têm os status e nem quais são os gerais e quais os específicas.

23.Em primeiro lugar, Aristóteles estabeleceu dez princípios, em torno dos quais toda questão parece girar. Ovoía [essência], que Plauto chama essentia (simplesmente não há outro termo em latim) e que busca saber "se existe". "Qualidade”, cujo sentido é claro. "Quantidade”, que, posteriormente foi dividida em duas: tamanho e número. "Relação", que deu origem à transferência e à comparação ${ }^{232}$.

24.Depois dessas, a de "lugar" e a de "tempo"; na sequência "o fazer, o sofrer e o ter"233, como, por exemplo, "estar armado", "estar vestido". E,

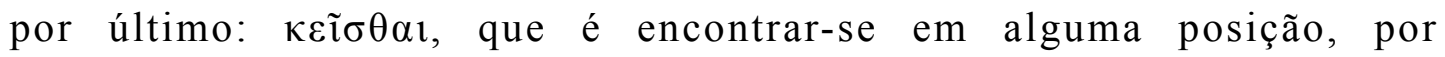
exemplo: "estar deitado", "estar de pé". No entanto de todas essas, as

\footnotetext{
231 Nomenclatura utilizada por Teodoro.

232 Ver 3.6.52; 7.4.12.

233 Donald Russell (2001) p. 60, nota 20 entende habere aqui como o equivalente grego de है $\chi \varepsilon 1 v$, com o sentido de "encontrar-se em uma condição específica".
} 
quatro primeiras dizem respeito ao status; as demais parecem estar relacionadas a alguns tópicos da argumentação.

25.Outros estabeleceram nove categorias: pessoa ${ }^{234}$, em que se investiga a alma, o corpo e fatos externos - o que eu entendo como elementos que dizem respeito à conjectura e à qualidade. O tempo, que os gregos

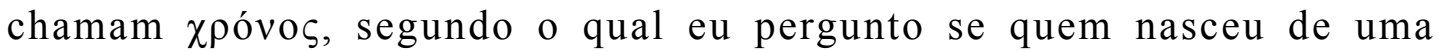
mãe que está sob fiança por dívidas nasce como escravo ${ }^{235}$. O lugar, donde parece surgir a controvérsia: é um crime matar um tirano dentro de um templo 236 ? Exilou-se aquele que se escondeu na própria casa?

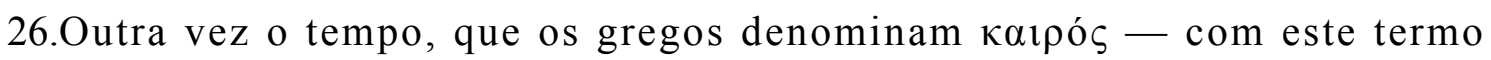
pretendem que se entenda outro tipo de tempo, como o verão ou o inverno. Inclui-se nesta categoria aquele caso de um fanfarrão em época de peste 237 . O ato, ou seja a $\pi \rho \alpha ́ \xi ı$, que trata deste ponto: "cometeu uma falta deliberadamente ou não? por necessidade ou por acaso?" e afins. O número, que inside sobre a categoria da quantidade. Por exemplo:

\footnotetext{
${ }^{234}$ Ad Her. 2.5; Cícero, Inv. 2.28; Part. 35.

235 Segundo uma antiga lei, uma pessoa que não conseguisse pagar uma dívida ficaria afiançada (addictus) ao seu credor por meio da manus iniectio ["apreensão corporal"] e após seis dias poderia ser vendida como escrava ou morta. Posteriormente a lex Postelia eliminou a escravização e a execução, mas manteve o direito do credor deter o devedor. Comparar com 5.10.60 e 7.3.26-27. Quintiliano deixa claro que um addictus por dívida não perde seus direitos pessoais.

236 Matar um tirano não é crime, mas é crime cometer assassinato dentro de um templo. Exemplo não mencionado em outras fontes. Sêneca (Con. 4.7) apresenta uma situação parecida: acaso um adúltero, ao ser surpreendido por um tirano, o matasse, deveria receber a recompensa por matar um tirano?

237 Em seu comentário, Taylor (1971) p.224 entende que o emprego de ille indica tratar-se de um tópico usual, embora não seja encontrado em nenhum outro texto. Russell (p.60, nota 23) interpreta que a diversão pessoal em período crítico seria uma ofensa ao estado.
} 
“devem-se a Trasíbulo trinta prêmios por haver suprimido esse número de tiranos?"238;

27. A causa, que abarca numerosos processos, todas as vezes em que não se nega o fato, mas em se defende que o episódio se deu por uma razão justificada. O $\tau \rho o ́ \pi o s$ [maneira], quando se diz que o que seria lícito ter sido feito de um modo foi feito de outro; por exemplo: "aquele adúltero foi morto açoitado ou por inanição?”. A ocasião para agir, que está tão claro que dispensa explicação ou exemplo para demonstrá-la, chamada

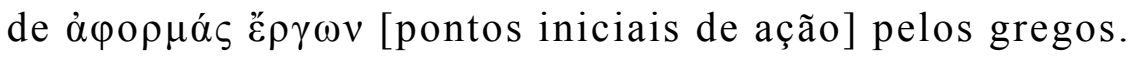

28. Tais autores consideram que não há mais nenhuma questão além dessas. Outros destacam duas partes: número e ocasião, e no lugar daquilo que eu chamei "ato" eles acrescentam "fatos”, isto é, $\pi \rho \alpha ́ \gamma \mu \alpha \tau \alpha$. Para não parecer omisso, eu considerei que bastava mencioná-las. Ademais creio que elas não dão conta da apresentação do status nem abrangem todos os seus tópicos, o que ficará evidente a quem ler com mais cuidado o que vou dizer sobre esses dois pontos 239 , já que há muito mais detalhes do que tais categorias podem abarcar.

29.Li em muitos autores que alguns consideram haver, de maneira geral, um único status conjectural. Mas tais autores não informam quem foram, nem eu mesmo consegui encontrar informação em parte alguma. Dizem, porém, que seguiram o método de reunir todos os fatos por meio dos

\footnotetext{
238 Em Contra Ctesifinte (187), Ésquines relata que Trasíbulo de Estíria e seus companheiros deviam receber 1000 dracmas e uma coroa de louros por haverem matado os trinta tiranos.

239 Discutido na sequência e também em 5.10.20-118.
} 
indícios ${ }^{240}$. De forma equivalente é possível também que estabeleçam somente um único status de qualidade, posto que em todo lugar pode ser investigada qual é a natureza de cada assunto. Porém, em qualquer dos dois casos seguirá uma enorme confusão.

30.E não faz diferença estabelecer um único ou nenhum status se todas as causas têm a mesma condição ${ }^{241}$. Conjectura deriva de $\operatorname{coniectus}^{242}$, ou seja, uma espécie de direcionamento da razão em direção à verdade; daí que também os intérpretes de sonhos e augúrios sejam chamados coniectores. No entanto, este gênero tem uma nomenclatura muito variada, o que vai ficar evidente pelo que segue.

[Quantos e quais são os status]

31.Houve quem estabelecesse dois status. Arquidemo ${ }^{243}$ considerou o conjectural e o de definição, excluindo a qualidade, porque julgava que a partir desta poderia ser perguntado o seguinte: "o que é hostilidade?, o que é injustiça?, o que pode ser desobediência?"; o que ele chama de status do mesmo e do outro.

\footnotetext{
240 Cícero, Orat. 45.

241 Cousin (p. 182) atribui o sistema de um único status a rétores sicilianos, sem no entanto nomear nenhum em particular.

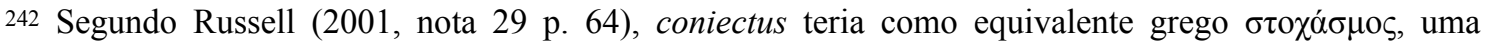
metáfora de mirar em um alvo.

243 Provavelmente o filósofo estóico Arquidemo de Tarso (séc. II a.C.), aluno de Diógenes de Selêucia (cf. Taylor (1971), p.226).
} 
32. Defendiam opinião diferente aqueles que postulavam a existência de dois status, mas um seria o de negação, e o outro, o judicial244. Status de negação é aquele que chamamos conjectural, e alguns rétores assim o chamaram porque atribuíram o termo oriundo de negação completa; outros, de uma negação parcial, julgando que o acusador faz uso da conjectura, e o réu, da negação.

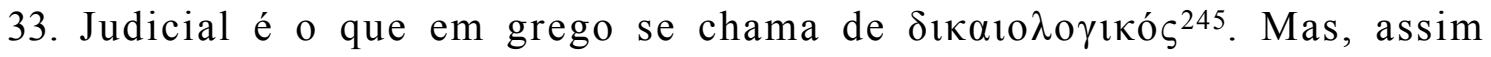
como Arquidemo excluiu a qualidade, alguns rejeitaram a definição. Eles a incluíram no judicial, considerando que se deve investigar se é justo chamar o que é alegado pela defesa sacrilégio, furto ou loucura.

34. Pânfilo 246 era dessa opinião, mas dividiu a qualidade em vários tipos. Posteriormente, muitos autores, mudando apenas a nomenclatura, propuseram uma divisão em caso sobre o qual não há consenso e caso sobre o qual há consenso. Com efeito, nem pode ser diferente: ou há certeza que o fato ocorreu, ou não há. Se não há certeza é status de conjectura; se há certeza, são os demais status.

35. Isso também afirma Apolodoro 247 , ao considerar que a questão encontra-se ou em assuntos externos, por meio dos quais se explica a conjectura, ou em nossas opiniões. O primeiro caso ele chama de

${ }^{244}$ Seguindo Hermágoras, status iuridicialis seria uma subdivisão do status de qualidade (cf. Cousin, p. 169 , nota 2).

${ }^{245}$ Equivalente do termo latino iuridicialis, aparece na Retórica a Herênio (1.14) na descrição do status de qualidade.

246 Pode ser o mesmo Pânfilo mencionado por Aristóteles, na Retórica (1400a4) ou por Cícero, no Do orador $(3.81)$.

247 Ver 3.1.17 e 3.1.34-43. 


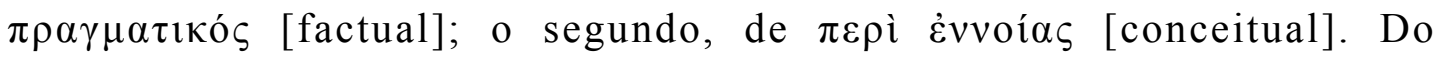
mesmo modo, há os que denominam respectivamente, ả $\rho$ ó $\lambda \eta \mu \pi \tau o \varsigma$ e

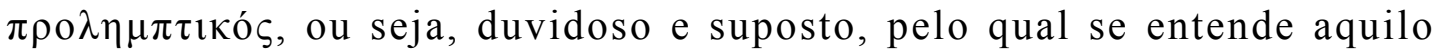
sobre o qual há indícios.

36. O mesmo entende Teodoro ${ }^{248}$, que considera ser preciso investigar se houve um fato e, tendo havido, quais suas ocorrências acidentais, ou

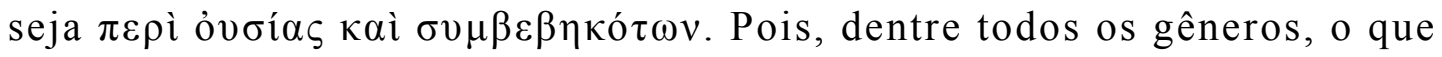
vem primeiro é o da conjectura; na sequência, os demais. Estes tipos restantes, segundo Apolodoro, são dois: o da qualidade e o do nome, isto é, o de definição. Teodoro, por sua vez, os classificou em essência, qualidade, quantidade e relação.

37.Há também quem pretenda que sobre a questão de identidade e de diferença esteja ora no âmbito da qualidade, ora no âmbito da definição ${ }^{249}$. Também Posidônio ${ }^{250}$ divide-os em dois tipos: dicção e fatos. Com relação ao de expressão considera que se investigam significado, natureza, quantidade e modo. No de fatos se investigam

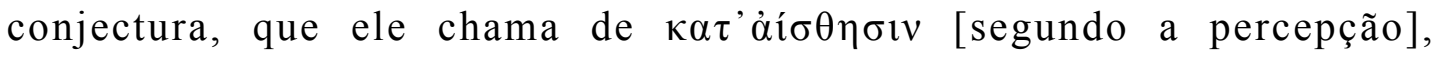
qualidade, definição, a que dá o nome de $\kappa \alpha \tau^{\prime}$ Ěvvorav [segundo o significado] e relação. Daí a divisão em escritos e não escritos.

\footnotetext{
248 Idem.

249 Cf. Cícero, Top. 85-87.
}

250 Possivelmente trata-se do filósofo estóico, professor de Pompeu e Cícero (cf. Kennedy (1963) p. 328). Segundo Jean Cousin (nota compl. 2, p. 270) esse texto de Posidônio é desconhecido. A divisão $\varphi \omega v \eta ́ /$ $\pi \rho \alpha ́ \gamma \mu \alpha \tau \alpha$ [expressão verbal/coisas] é característica da filosofia estóica, que considerava a retórica um ramo da lógica. Ver Taylor (1071) pp.237-239. 
38. Também o próprio Cornélio Celso estabeleceu dois status gerais: se o fato existe e de que natureza é. No primeiro tipo ele incluiu a definição, porque seria possível se investigar igualmente se é sacrílego aquele que declara não ter roubado nada do templo ou aquele que alega que roubou dentro do templo dinheiro privado. Ele dividiu a qualidade em fato e letra da lei. Na letra da lei incluiu quatro partes legais, excluindo a transferência; na conjectura incluiu a quantidade e a questão de intenção.

39. Existe ainda outro método de dividir os status em dois. Segundo este procedimento, a controvérsia é ou de substância ou de qualidade; a qualidade, por sua vez, pode estar relacionada a seu aspecto mais geral ou a temas decorrentes deste 251 .

40.A substância está implicada na conjectura; pois sobre qualquer fato, é possível perguntar: “aconteceu? acontece? vai acontecer?" 252 e algumas vezes se inclui também a intenção. Esta classificação é melhor do que aquela que propõe chamá-lo de status de fato, como se se tratasse somente do passado e do fato já ocorrido.

41.A parte do status de qualidade que trata de aspectos gerais poucas vezes se vê num tribunal. Por exemplo, quando se pergunta "é honroso aquilo que é elogiado pelo povo?" Mas a outra parte, que trata de um tema decorrente do geral, refere-se a uma denominação ambivalente. Por

\footnotetext{
251 Ver 7.4.1.
}

${ }^{252}$ Cf. Cícero, Inv. 1.11. 
exemplo: "é um sacrílego aquele que roubou dinheiro privado do templo?" Ou sobre uma coisa determinada, quando é certo que aconteceu, se conhece o lugar onde ocorreu e não se duvida de sua natureza. Nestes tipos estão incluídas todas as questões que tratam do honroso, do justo e do útil.

42.Diz-se que nestes estão contidos todos os outros status, uma vez que a quantidade se referiria ora à conjectura - por exemplo: "o sol é maior que a terra?" - ora à qualidade — por exemplo: "qual o tamanho do castigo ou da recompensa é justo atribuir a alguém?”. E a transferência estaria relacionada com a qualidade, bem como a definição seria parte da transferência.

43.Além disso, há ainda as leis contraditórias e o status raciocinativo, ou seja, silogismo. A maior parte das questões, tanto da letra da lei quanto da intenção, toma como base a equidade (exceto quando este terceiro tipo de questão envolve a conjectura, por exemplo, quando se pergunta “o que pensou o legislador?"). Por outro lado, a ambiguidade necessariamente deve ser sempre explicada pela conjectura, porque, sendo evidente que o significado das palavras é ambíguo, investiga-se exclusivamente a intenção.

44.A divisão em três status gerais foi adotada pela maioria dos autores, entre eles Cícero, que a emprega no Orador $^{253}$, considerando que eles compreendem tudo aquilo que entram ou em controvérsia ou em disputa.

253 Orat. 45 e 121. Também em Part. 101; Top. 92-96; e de Orat. 2.14. 
Assim se pergunta: “é?, o que é?, de que natureza é?” — tais denominações são tão claras que dispensam explicação. O mesmo entende Iátrocles.

45.E também Marco Antônio254 estabeleceu três tipos de status, com as seguintes palavras: "poucos são os fatores que dão origem a todos os discursos, o ocorrido e o não ocorrido, o justo e o injusto, o bom e o mau". No entanto, pelo fato de que quando se diz que agimos com justiça não significa somente que atuamos conforme a lei, mas tem também aquele outro sentido de que supostamente agimos com legitimidade, os seguidores de Antônio quiseram distinguir com mais clareza esses status. Sendo assim, apresentaram o status conjectural, o legal, e o judicial, classificação aprovada também por Virgínio ${ }^{255}$.

46.Posteriormente eles subdividiram esses status. Assim, ao status legal subordinam o da definição e os outros derivados da letra da lei: o do conflito de leis, denominado antinomia; o da letra da lei e do sentido, ou

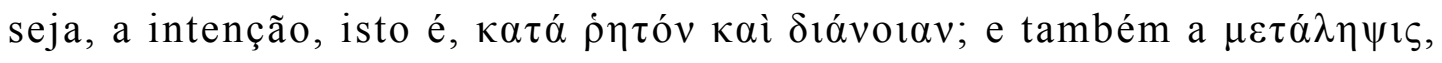
que denominamos de forma variada: transferência, traslado ou transposição; o $\sigma v \lambda \lambda o \gamma r \sigma \mu o ́ \varsigma$ [silogismo], que entendemos como o status raciocinativo ou dedutivo; e o status da ambiguidade, que é chamada $\dot{\alpha} \mu \varphi \imath \beta o \lambda i \alpha$. Eu os apresentei porque a maioria os chamam de status, embora haja alguns que prefiram chamá-los "questões legais".

254 Ver 3.1.19 e 3.6.34-43.

255 Ver 3.1.21. 


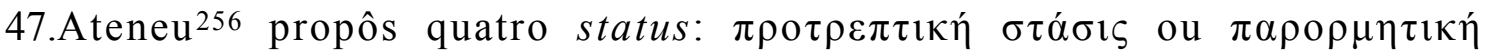

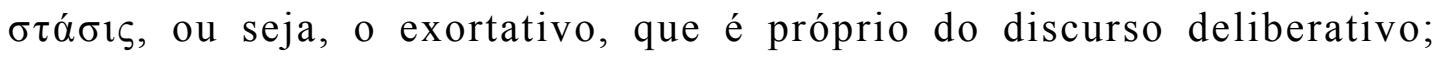

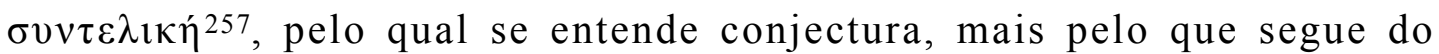

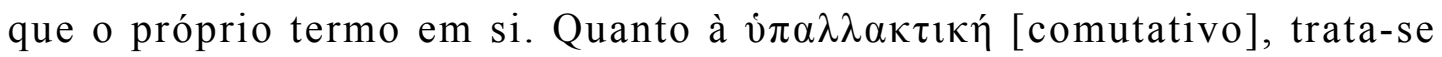
da definição, pois consiste na mudança de nome; e o status judicial, para o qual ele usou o mesmo termo em grego que os demais. Como disse 258 , há muita variação na nomenclatura.

48.Há os que, adeptos do significado de mudança, consideram que

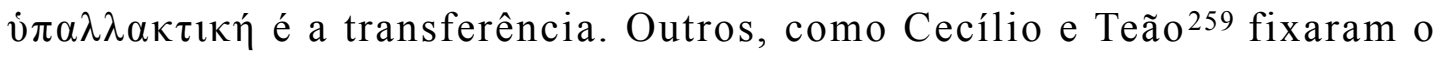
mesmo número de status [de Ateneu], mas distintos: "existe?, o que é?, de que natureza é?, de que tamanho é?".

49.Aristóteles, na Retórica 260 , considera que se deve investigar: "existe?, de que natureza é?, qual é o tamanho? e qual a quantidade?". Numa passagem ${ }^{261}$, porém, ele reconhece a ideia de definição, quando diz que é preciso se defender de certas acusações da seguinte maneira: "subtraí, mas não pratiquei um furto; bati, mas não ofendi a lei”.

\footnotetext{
256 Ver 3.1.16.

${ }^{257}$ Ver Cousin, nota complementar p. 270.

258 Cf. 3.6.22.

259 Provavelmente o estoico Élio Teão de Alexandria, contemporâneo de Quintiliano, que escreveu u $\mu \alpha$

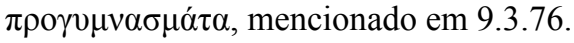

${ }^{260}$ Rh. 3.1416a 6-9; 1417a 8-10; 1417b 21-27.

261 Idem $1.1373 b 38$ ss.
} 
50.Também Cícero, em sua Retórica ${ }^{262}$, propôs quatro status: fato, nome, natureza e ação. Desse modo se entenderia o seguinte: no fato a conjectura; no nome a definição, no de natureza a qualidade, no de ação a lei. Ele incluiu a transferência no da lei. Em outra passagem ${ }^{263}$, no entanto, ele trata essas "questões legais" também como tipos de “espécies da ação".

51.Há rétores que propuseram cinco status: conjectura, definição, qualidade, quantidade, relação. Também Teodoro, como mencionei, emprega esses mesmos pontos principais: "existe?, o que é?; qual sua natureza?, qual sua importância?, relaciona-se a algo?”. E ele considera que este último poderia sobretudo ser abordado no gênero comparativo, porque não se entende o melhor e o pior, o maior e o menor senão comparando-os com outros.

52.Mas, como expliquei anteriormente ${ }^{264}$, estas questões também recaem naquelas transferíveis: "este homem tem o direito de fazer isso?, ou seria conveniente que fizesse outra coisa?, contra este homem?, nesta ocasião?, deste modo?". De fato, é preciso que todas essas perguntas estejam relacionadas a algo.

53.Outros pensam em seis status: conjectura, que chamam de $\gamma \varepsilon \dot{\varepsilon} \varepsilon \sigma i \varsigma ;$ qualidade; particularidade, ou seja i $\delta$ ió $\rceil \varsigma s$ (com tal termo apresenta-se a

\footnotetext{
262 Inv. 1.40 e $2.60-61 ; 65-58$

263 Part. 107-109 e 132-135.

264 3.6.36.
} 


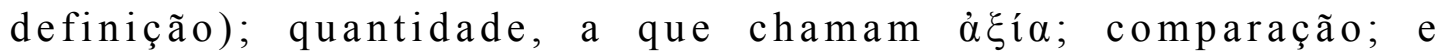
transferência, para a qual se encontrou um nova nomenclatura:

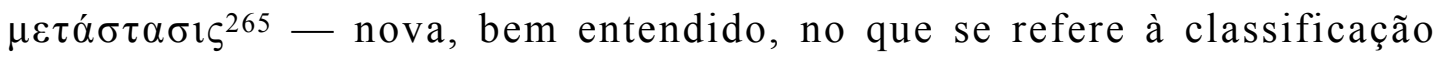
dos status, já que esse termo foi empregado com outro significado por Hermágoras entre os tipos de questões judiciais.

54.Outros pretendiam que fossem sete, e não foi reconhecida a transferência, nem a quantidade e tampouco a comparação, e sim colocaram quatro status legais no lugar desses três, adicionados àqueles três racionais.

55.Há os que chegaram até oito status, acrescentando a transferência aos sete anteriores. Além disso, alguns alteraram o sistema de classificação: dividiram entre status racionais e questões legais (como já mencionei anteriormente 266 ), sendo que nos primeiros se investiga o fato; nos últimos, a letra da lei. Outros, ao contrário, preferiram que fossem os últimos os status e os primeiros as questões.

56.Outros ainda estimaram haver três status racionais: "existe?, o que é?, de que natureza é?” E somente Hermágoras propôs quatro tipos: conjectura; particularidade 267 ; transferência; e qualidade, o que ele

265 Como observa Cousin (trad., nota 1, p. 175), a tradução usual para o latim de $\mu \varepsilon \tau$ ó $\sigma \tau \alpha \sigma ı$ é remotio criminis. Cícero, no Da Invenção (1.15), faz uma distinção entre aquilo que os gregos chamam uma

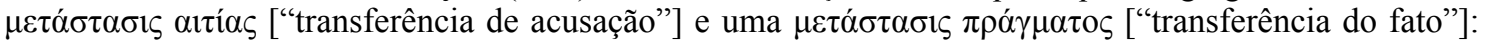

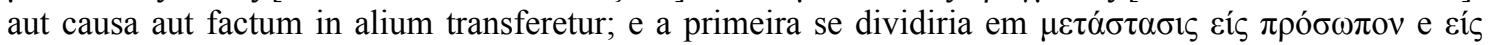
$\pi \rho \alpha ́ \gamma \mu \alpha$.

2663.6 .46$.

267 Em seu Comentário, Taylor (1971), p. 257, considera o termo uma provável confusão nas fontes de Quintiliano. Agosttinho (142.26.27H; apud Taylor), testemunha apenas finis (ópo̧) como um termo

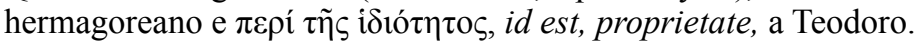




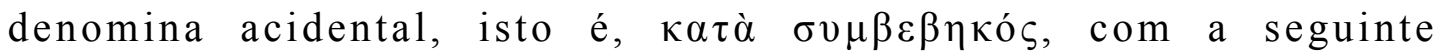
explicação: "tal homem calha de ser bom ou mal?". Ele a dividiu assim: sobre o que se deve buscar ou evitar, que é a parte deliberativa; sobre a pessoa, quando se apresenta a parte laudativa268.

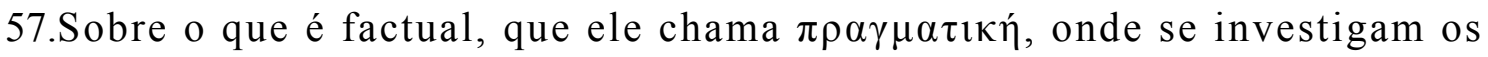
fatos em si, eliminando as pessoas envolvidas. Por exemplo: "é livre aquele que é reclamado como escravo?", “riquezas geram soberba?", “algo é justo?", “algo é correto?". E a parte judicial, que investiga praticamente o mesmo, mas que trata de pessoas específicas, por exemplo: "é justo ou correto o que este homem fez?"

58.Bem sei que no primeiro livro da Retórica de Cícero ${ }^{269}$ há outra explicação para o tópico factual. Segue o que ele escreveu: "factual é aquela parte em que se considera o que é da área jurídica de acordo com o uso civil e a equidade. Entre nós, acredita-se que cuidar dessa parte é tarefa dos jurisconsultos".

59.Mas eu já apontei acima a opinião do próprio Cícero sobre estes $\operatorname{livros}^{270}$. Certamente nesses apontamentos estão registros de tipo escolares que ele escreveu quando jovem, e se existem erros neles são de quem os ensinou, seja porque ele pode ter sido influenciado pelo fato de Hermágoras ter apresentado nesse passo primeiro exemplos de

\footnotetext{
268 Cícero, Inv. 1.12 e de Orat 3.116.

${ }^{269}$ Inv. 1.14.

270 Cícero, de Orat.1.5.
} 


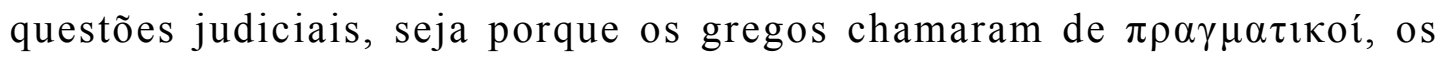
intérpretes da lei271.

60.De qualquer forma, Cícero substituiu esses textos por aqueles belíssimos do Orador. Por isso ele não pode ser responsabilizado de transmitir preceitos errados. Retornemos a Hermágoras. De todos, ele foi o primeiro a falar em transferência 272 , se bem que o embrião desse conceito, por assim dizer, sem o uso do termo, possa ser encontrado em Aristóteles 273 .

61.Quanto às questões legais, Hermágoras estabeleceu os seguintes status:

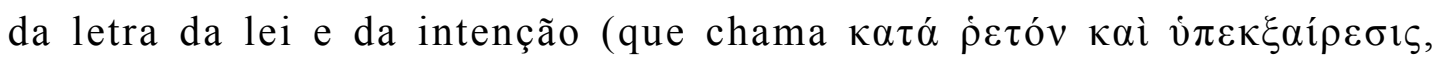
isto é, o dito e a exceção, sendo que o primeiro deles é comum a todos os autores, o termo "exceção" não é tão usado), o silogístico, o da ambiguidade, e o de leis contraditórias.

62.Albúcio ${ }^{274}$, usando a mesma divisão, exclui a transferência, subordinando-a ao status judicial. E ele ainda considera que nas questões legais não há nenhum status silogístico. Sei que muito mais detalhes sobre esse tema serão encontrados por quem quiser ler os autores antigos, mas temo que estas considerações já tenham ultrapassado a medida.

\footnotetext{
271 Cícero, de Orat. 1.198, 253.

272 Cf. Cícero, Inv. 1.16.

273 Rh. 1416 a 28-34.

274 Ver 3.3.4.
} 
63.Confesso que eu mesmo tenho uma opinião um pouco distinta da que tinha incialmente. E talvez estivesse fosse mais seguro, no interesse de minha reputação, nada mudar daquilo que durante muitos anos eu não apenas considerei verdade como também aprovei.

64.Mas não aceito a ideia de ser deliberadamente dissimulado em algum aspecto do que penso, sobretudo numa obra que escrevo para que tenha alguma utilidade para jovens de bem. E também Hipócrates ${ }^{275}$, célebre na arte da medicina, parece ter agido de forma extremamente honesta, ao confessar alguns erros para que pósteros não errassem. Também o próprio Marco Túlio não hesitou, em escritos posteriores, em condenar alguns livros já editados, como Cátulo e Luculo ${ }^{276}$ e aqueles sobre arte retórica, que já mencionei.

65.A verdade é que um trabalho mais detido nesses estudos seria em vão se não fosse permitido encontrar uma exposição melhor do que as do passado. Mesmo assim, não foi supérfluo o que eu então ensinei com base nisso, pois também os preceitos que ensinarei agora servirão a estas minúcias. E, assim, que ninguém se arrependa de ter aprendido o assunto, eu apenas esforço-me em reunir e apresentar o mesmo material de uma maneira um pouco mais elucidativa. É que quero todos satisfeitos com o fato de que não demoro mais tempo em apresentar esse tema a outros mais do que eu mesmo demorei para persuadir-me dele.

\footnotetext{
275 Hipócrates, Epid. 5.27, quando o médico confessa ter errado no diagnóstico de um ferimento na cabeça de um paciente.

276 Cícero, Acadêmicos, do qual fazem parte esses diálogos.
} 
66. Seguindo a maioria dos autoridades, eu mantinha três status racionais conjectura, qualidade, definição — e um único legal. Tais eram para mim os status gerais. Dividia o legal em cinco espécies: letra da lei e intenção, leis contraditórias, recaptulativo, ambiguidade, transferência.

67.Percebo agora que é possível suprimir o quarto dos status gerais; bastando a primeira divisão, segundo a qual, como dissemos, uns são racionais e outros, legais. Desse modo, o quarto não será um status, mas sim um gênero de questões, do contrário ele seria também um status racional.

68.E ainda dentre os que classificava como específicos, excluí a transferência. É bem verdade que muitas vezes afirmei (como podem recordar todos os meus discípulos), mesmo naquelas exposições publicadas contra minha vontade 277 , que dificilmente o status de transferência pode encontrar-se em alguma controvérsia, sem dar a impressão de que outro nome, nesta mesma circunstância, lhe foi dado corretamente. Daí que alguns o tenham excluído.

69.E não ignoro que a transferência ocorre muitas vezes, quando em quase todas as causas, nas quais se diz que houve um erro processual278, têmse as seguintes questões: "esta pessoa tem o direito de intentar uma ação?, contra este homem?, segundo esta lei?, perante este tribunal?, nesta circunstância?" e outras.

\footnotetext{
277 Ver livro 1, proêmio 7.

278 Como observa Cousin (nota 1, p.179), a expressão mais usual seria causa cadere, a forma formula cadere já aparece em Sêneca, Ep. 68.10 .
} 
70.Mas pessoas, circunstâncias, ações e etc. são transferidos por algum motivo, assim a questão não está na transferência, mas no motivo da transferência: “deves solicitar o fideicomisso 279 não ao pretor, e sim aos cônsules, pois a quantia é maior que a que corresponde à jurisdição do pretor”. Então investiga-se se a quantia é maior, trata-se de uma controvérsia de fato.

71."Não tens o direito de processar-me, pois sei que não podias atuar como acusador", a deliberação é se tinha o direito de acusar. "Não deverias ter feito uma interdição, e sim uma petição" ${ }^{280}$, então se discute se a interdição foi aplicada corretamente. Todas essas circunstâncias relacionam-se a questões legais.

72.Ou será que mesmo as exceções em que a transferência parece particularmente evidente não apresentam todas as mesmas espécies que as leis segundo as quais se intentam as ações, de modo que se investigue o nome, a letra e a espírito da lei ou o silogismo? Nessa situação o status tem origem na questão. A transferência não apresenta a questão sobre a qual o orador litiga, mas por causa da qual litiga.

73.Um exemplo mais claro: "mataste um homem. Não matei”. A questão é se ele matou, o status é de conjectura. Não é o mesmo: "tenho direito a

\footnotetext{
279 Disposição em que um testador deixa sua herança ou parte dela sob a guarda de uma pessoa para que numa determinada data e ocasião seja entregue a seu beneficiário. Na época de Augusto o fideicomisso entra na esfera judiciária, quando passa a ser tarefa dos cônsules zelar por ele. Na época de Cláudio isso passou a ser função do pretor, mas os cônsules poderiam ser solicitados a intervir quando se ultrapassava determinada quantidade de bens ou dinheiro.

280 Enquanto a interdição visa proteger um fato jurídico apresentando uma queixa ou denúncia, a petição, por sua vez, alega um direito imobiliário de fato.
} 
uma ação judicial. Não tens" — aqui a questão é se ele tem direito, daí vem o status. Ter ele direito ou não à ação depende do efeito e não da causa, da decisão do juiz e não do motivo da decisão.

74.Um exemplo semelhante é: “deves ser punido. Não devo". O juiz examinará se deve ser punido. Porém não é neste ponto que residirão a questão e o status. Onde então? "Deves ser punido, mataste um homem. Não matei" - na pergunta se ele matou. "Devo receber honras. Não deves": haveria um status aqui? Creio que não. "Devo receber honras porque matei um tirano 281 . Não mataste”. Aqui sim, há uma questão e um status. Da mesma maneira não há status no seguinte: "Não intentas o processo conforme a lei. Intento".

75.Onde há então? "Não é correto intentares uma ação, estando privado de direitos civis" 282 . Investiga-se se ele está privado de direitos civis ou se alguém em tal condição tem o direito de intentar uma ação. Eis as questões e os status. Há portanto, um gênero de causa transferível, bem como um gênero comparativo e um de mútua acusação 283.

76.Alguém pode dizer que são semelhantes os seguintes exemplos: "eu tenho o direito. Não tens"; "mataste. Matei com justiça”. Não vou dizer que não, porém essas circunstâncias não produzem um status, pois não

\footnotetext{
${ }^{281}$ Em outras passagens - 7.2.25; 4.21; 7.2-3 — Quintiliano retorna ao tema da morte de um tirano.

282 Ignominiosus: denota alguém marcado pela nota censoria, mas neste caso tem uma conotação jurídica, definindo um infame, aquele que perdeu seus direitos legais em outras causas.

283 Para Quintiliano há apenas dois gêneros de causa: a simplex e a coniuncta, de acordo com o número de status. Mas depois, neste mesmo capítulo, ele apresenta um terceiro tipo: o comparatiuum, distinto dos dois anteriores (3.10.3), mas que seria um subgênero da causa coniuncta. No entanto, esses três últimos tipos não têm um status.
} 
são proposições (caso contrário a causa não terá desenvolvimento), a não ser quando acompanhadas de suas motivações."Horácio cometeu um crime, pois matou sua irmã. Não cometeu um crime, porque ele tinha que matar aquela que chorava a morte de um inimigo"284. Aqui a questão é se a causa é justa; é, portanto, status de qualidade.

77.De forma parecida ocorre na transferência: "não tens o direito de deserdar 285 , porque uma pessoa desprovida de direitos civis não pode intentar uma ação. Tenho o direito, porque deserdar não é intentar uma ação". Pergunta-se: o que é intentar uma ação? Podemos definir "não é lícito deserdar um filho" como um status de silogismo. O mesmo vale para todos os outros status, tantos os racionais como os legais.

78.Bem sei que houve quem incluísse a transferência também no gênero racional, da seguinte maneira: "matei um homem por ordem do comandante", "entreguei as oferendas do templo ao tirano porque ele me obrigou" 286 , “desertei porque estava impedido de combater pela tempestade, por causa dos rios e de minha saúde" 287 , ou seja, não dependia de mim, e sim disso tudo.

79.Discordo ainda mais abertamente deles. Pois não é a ação que é transferida, mas a causa do fato, o que ocorre em quase toda defesa.

\footnotetext{
284 Tema familiar; aparece em outra passagem da Institutio oratoria (7.4.8) e no Da Invenção (2.78-79) de Cícero.

285 A abdicatio de um filho é outro tema recorrente na Institutio: 5.10 .107 e 13.32; 7,1.42, 47 e 53; 7.4.11; 9.2.98.

286 Tema do tirano que se repete em Sêneca, Con. 9.4.10.

287 Tema do soldado impedido que aparece também na Retórica a Herênio 1.23.
} 
Além disso, aquele que usa este tipo de justificativa não prescinde do status de qualidade se ele afirma ser inocente. Um raciocínio duplo se constrói, baseado principalmente no status de qualidade ${ }^{288}$ : por um lado, defende-se o fato em si; por outro, somente o réu.

80.Deve-se dar crédito, então, àqueles cuja autoridade Cícero seguiu ${ }^{289}$, alegando que em todo debate havia três tipos de status: "existe?, o que é?, como é?", o que inclusive a própria natureza nos ensina. Primeiramente, é preciso haver algo que apresente ambiguidade, porque não é possível estimar ao certo o que é e de que natureza é, se antes não houver acordo antes de que algo existe. Daí que esta seja a primeira questão.

81.Mas não é por estar claro que algo existe, que já está evidente o que é. Uma vez definido também isto, resta a qualidade, e não há nada mais a tratar depois de mostrar esses pontos: é neles que residem as questão indefinidas e as definidas. Pelos menos algumas delas são abordadas como matéria demonstrativa, deliberativa ou judicial.

82.Esses mesmos pontos, por sua vez, abarcam as causas judiciais, tanto na parte racional quanto na legal. E nenhum debate jurídico pode ser constituído de outra forma que não seja através da definição, da qualidade e da conjectura.

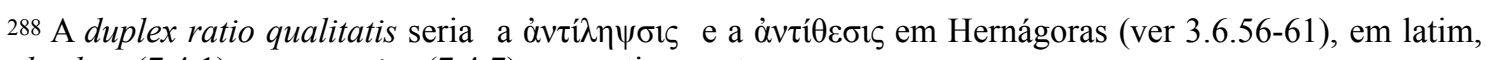
absoluta (7.4.1) e assumptiva (7.4.7), respectivamente.

289 Cícero, Orat. 45 e de Orat. 1.139; 2.104; 3.70; Part. 33, 62, 101; Top. 82, 92.
} 
83.Mas para professores de iniciantes não será inútil, num primeiro momento, um método mais abrangente, e o caminho, se de imediato não estiver numa linha estritamente reta e direta, será, entretanto, mais fácil e mais acessível. Antes de tudo, então, que aprendam que há uma quadripartição do método em todas as causas, que deve ser examinada logo no início pelo futuro litigante. Priorizando a defesa, começarei falando do primeiro, que de longe é o método mais consistente de defesa: se é possível negar aquilo de que se é acusado. O seguinte, se é possível dizer que não ocorreu o fato do qual somos acusados. O terceiro - o mais honroso - é defender que o fato se deu dentro da lei. E se não dispusermos desses argumentos, certamente há o último ponto: resta a única saída, que consiste em escapar, por meio de algum expediente do direito, de uma acusação que não é possível negar nem defender, de modo que a ação pareça estar sendo apresentada ilegalmente.

84.Daí surgem as questões de ação ou de transferência. Algumas práticas não são por natureza louváveis, mas permitidas legalmente (por exemplo, consta nas Doze Tábuas que era lícito dividir o corpo do devedor entre seus credores, mas a moral pública repudiava essa lei) ${ }^{290}$;

290 De acordo com as Doze Tábuas, alguém que tivesse sido condenado por dívidas poderia ser cortado em pedaços pelos seus credores, para que vingassem suas dívidas, não importando o tamanho do pedaço. (cf. Gel. 20.1.48) 
e havia a prática justa, no entanto proibida pela lei, da ampla liberdade testamentária291.

85.O acusador não deve observar nada além do seguinte: o que comprova que o fato se deu, que o fato é o que ele apresenta, que o fato não é justificável, e que o processo intentado está dentro da lei. Desse modo, todo litígio versará em torno das mesmas espécies, algumas vezes invertendo-se as partes. Por exemplo, nas causas que tratam de recompensas, aquele que demanda é quem deve provar que o fato ocorreu dentro da lei.

86.Estes quatro pontos propostos ou formas de ação, por assim dizer, que então eu denominava status gerais, dividem-se, como já demonstrei, em dois gêneros: racional e legal. O racional é mais simples, porque consiste apenas na contemplação da própria natureza do caso. De forma que a seu respeito já é suficiente terem sido demonstradas a conjectura, a definição e a qualidade.

87.Quanto ao gênero legal, é inevitável que haja várias espécies, uma vez que há muitas leis e elas têm distintos aspectos. Em uma nos apoiamos em suas palavras; em outra, na intenção. Recorremos a outras, quando não temos uma lei específica para o caso; comparamos algumas entre si; e outras ainda interpretamos de modo diferente do usual.

291 A liberdade de elaborar testamentos não era irrestrita, era necessário cumprir alguns requisitos como ser livre, cidadão ou ao menos dono de um commercium, estar sui iuris, não ser louco nem impúbere, havendo ainda restrições a mulheres, pessoas surdas, mudas, etc. Ver Cousin (nota complementar p.273). 
88.Assim, têm origem esses simulacros, por assim dizer, daqueles três status, algumas vezes simples, outras também compostos, apresentando, porém, uma forma própria. Como o da letra da lei e intenção, que indubitavelmente está compreendido na qualidade ou na conjectura. Também o $\sigma v \lambda \lambda o \gamma 1 \sigma \mu o ́ \varsigma$, que está particularmente associado à qualidade. E ainda as leis contraditórias, que constam dos mesmos elementos que os da letra da lei e intenção. Por fim a $\alpha \mu \varphi \imath \beta o \lambda i ́ \alpha$ [ambiguidade], que sempre é desenvolvida pela conjectura.

89. Também a definição é comum aos dois gêneros, seja aquele que consiste na observação dos fatos, seja aquele da observação da letra da lei. Todos eles, mesmo que estejam incluídos naqueles três status, ainda assim, por terem, como afirmei, algo próprio, por assim dizer, parece que devem ser explicados aos aprendizes, permitindo-lhes denominá-los status legais ou "questões" ou "pontos capitais menores", contanto que saibam que nem mesmo neste caso há algo a investigar além das três pontos que já ensinei.

90.Mas a dimensão, a quantidade, a relação, e também, como alguns consideraram, a comparação não seguem o mesmo procedimento, pois tais questões devem ter relação não com a variedade de leis, e sim apenas com o método. Daí que sempre devam ser consideradas como parte da conjectura ou da qualidade, por exemplo, quando se pergunta: “com que intenção?”, “em que momento?”, “onde?”. 
91.Mas falarei de cada uma dessas questões quando começar a tratar dos preceitos da divisão 292 . Um ponto é consenso entre todos: nas causas simples, as causas apresentam um único status, mas nas questões, que lhes estão subordinadas, por assim dizer, e se referem ao ponto em que se fundamenta o julgamento, com frequência acontece de muitas poderem incidir numa única causa.

92.Acredito, ainda, que, por vezes, há dúvida sobre qual status empregar no caso em que há muitas opções de defesa contra uma única acusação. Assim, como se diz, sobre o tom de uma narração, que o melhor é aquele a que o ator é mais capaz de se ater, da mesma forma aqui também é possível dizer que o orador deve empregar o status que lhe permita alcançar maior eficácia caso se atenha a ele.

93.Eis a razão por que Cícero, ao defender Milão, empregou um determinado modo de defesa, diferente do utilizado por Bruto, ao escrever o discurso como exercício ${ }^{293}$. O primeiro alegou que Clódio foi morto justificadamente, por ter preparado uma emboscada, e mesmo assim sem que Milão o premeditasse. Enquanto o segundo chegou a se vangloriar pelo assassinato de um cidadão perverso.

94.Em causas complexas, por sua vez, é possível encontrar dois ou três status, sejam de gêneros variados — por exemplo, se alguém alega não

\footnotetext{
292 Assunto do livro 7.

293 Ver 10.1.23.
} 
ter feito algo ou que o fez dentro da lei —, sejam do mesmo gênero quando se nega tudo.

95.O que também pode ocorrer quando um único bem está em questão, mas várias pessoas o demandam, segundo o mesmo direito, no caso de parentesco, ou direitos diferentes, quando um se apoia no testamento e outro, no parentesco. Todas as vezes, porém, que diferentes interposições são feitas a diferentes demandantes, é necessário que o status seja diferente, como a controvérsia que apresento a seguir.

96.Os testamentos feitos dentro da lei sejam validados; os filhos de pais sem testamentos sejam os herdeiros; que não receba nada do patrimônio do pai o renegado; que o filho ilegítimo nascido antes do legítimo seja considerado filho legítimo; e aquele ilegítimo que nascer depois do legítimo seja somente um cidadão e que seja lícito dá-lo em adoção; depois de dado em adoção, que lhe seja permitido voltar à família se o pai natural morrer sem filhos.

97.No caso daquele pai que, com dois filhos legítimos, dera um em adoção, renegara o outro, além de conservar o ilegítimo, e depois de instituído como herdeiro o renegado, então, morreu. Todos os três disputam os bens. Os gregos chamam nothos ${ }^{294}$ o filho que não é legítimo, nós não temos um termo latino para isso, como inclusive atestou Catão em um de

${ }^{294}$ Enquanto o vóӨo era ilegítimo de pai conhecido, o spurius era de pai desconhecido (Cousin, nota $1 \mathrm{p}$. 186). 
seus discursos 295 , e por isso empregamos um termo estrangeiro. Mas voltemos ao nosso propósito.

98.Ao herdeiro instituído por escrito opõe-se a lei: “o renegado não herdará nenhum bem paterno". Neste caso, dá-se o status da letra da lei e intenção: pode ele herdar de algum modo, seja pela intenção do pai, seja porque está inscrito como herdeiro? A respeito do filho bastardo tem-se uma questão dupla: se nasceu depois dos filhos legítimos ou antes de algum filho legítimo.

99.A primeira situação apresenta um $\sigma v \lambda \lambda o \gamma 1 \sigma \mu o ́ \varsigma$ [silogismo]: devem ser considerados como não natos aqueles filhos que foram renegados pela família? A outra situação é da letra da lei e intenção: certamente há consenso de que esse filho não tenha nascido antes de um filho legítimo, mas ele se defenderá pelo espírito da lei, que alegará implicar que é legítimo o bastardo que nasceu quando ainda não havia um legítimo na casa.

100. E também poderá excluir a interpretação literal da lei, alegando que em todo caso o ilegítimo não será prejudicado se depois não nascer um legítimo, empregando o seguinte argumento: "suponha que nasça somente um ilegítimo, qual será sua condição? Apenas a de cidadão? Mas ele não terá nascido depois de um filho legítimo. Ou a de filho? Mas não terá nascido antes de um filho legítimo. Por isso, uma vez que 
não é possível apoiar-se no texto da lei, deve-se buscar apoio na intenção".

101.Não quero deixar ninguém confuso se de uma única lei surgirem dois status: a lei é dupla, de modo que tem o valor de duas. Ao filho que quer retornar à família, o outro filho, antes de mais nada, diz: “Ainda que tenhas o direito de retornar, o herdeiro sou eu". Trata-se do mesmo status daquele que, deserdado, reclama herança: então se investigará a possibilidade de um deserdado ser herdeiro.

102.É apresentada igualmente pelos dois a seguinte objeção: "não tens o direito de retornar à família; pois nosso pai não morreu sem filhos". Mas, nesse caso, cada um se apoiará na sua questão específica. De fato, um alegará que um repudiado também está entre os filhos, aduzindo um argumento baseado na mesma lei pela qual é repudiado: teria sido desnecessário que o repudiado fosse privado dos bens paternos se fosse considerado um estranho. Mas agora, posto que seria herdeiro de um pai sem testamento, pelo direito de filho, ele tem uma lei que lhe é objetada, porque, ainda que ela não faça com que deixe de ser filho, faz com que deixe de ser herdeiro.

103.É um status de definição: o que é um filho? O ilegítimo, por sua vez, alega que o pai não morreu sem filhos, usando os mesmos argumentos que empregou na reivindicação para provar que era filho, a não ser que aqui, por acaso, ele retome a definição: são filhos também os não legítimos? Ocorrerão, portanto, em uma única controvérsia ou bem dois 
status legítimos, de um modo particular, o da letra da lei e intenção e o do silogismo, e além desses o da definição, ou aqueles três que, por natureza, são únicos: o da conjectura (no caso de letra da lei e intenção), o da qualidade (no caso de silogismo) e o da definição, que por si só é evidente.

104.Em todo gênero de causas encontram-se uma causa, um ponto a julgar e um fundamento. Nada pode ser dito que não tenha uma razão, alguma coisa a qual se refere o julgamento e algo que contenha a essência da matéria. No entanto, uma vez que esses temas variam muito em cada litígio e no geral são tratados por aqueles que escrevem sobre causas judiciais, adiemos seu tratamento para quando chegarmos a tal parte. Agora, posto que as causas dividem-se em três gêneros, seguirei esta ordem. 


\section{CAPÍTULO 7}

[Do elogio e vitupério]

1. Prefiro começar com aquela que consta de elogio e vitupério. ${ }^{296}$ Parece que Aristóteles297, e também seu discípulo Teofrasto, separou este gênero da parte

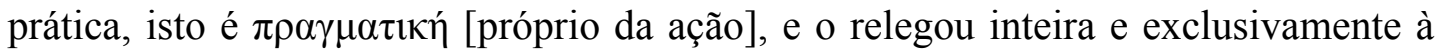
audiência. O nome deste gênero deriva de "exibição" 298 , o que revela sua principal característica.

2. Essa prática, porém, foi incluída também entre as funções públicas pelo costume romano, visto que os elogios fúnebres frequentemente estão relacionados com algum ofício público e muitas vezes são confiados aos magistrados por um senátusconsulto. Ademais, elogiar uma testemunha, ou o contrário, faz parte de um julgamento, sendo permitido aos acusados apresentar encomiastas de seus atributos ${ }^{299}$. E os discursos de Cícero publicados contra seus concorrentes, contra Lúcio Pisão ${ }^{300}$, contra Clódio e Curião ${ }^{301}$, contém vitupério e mesmo assim foram apresentados como um parecer formal no senado.

296 No Fedro (261b) se diz que são conhecidas regras somente para os discursos realizados diante do tribunal e nas assembleias populares. As primeiras regras para louvor aparecem na Retórica a Alexandre (3.35) e na Retórica de Aristóteles (I. 9), que já apresentam a divisão deste gênero em elogio e vitupério (Rh. Al. 1421b1o; Aristóteles Rh. 1366a24). Estrutura adotada pela tradição (cf. Ad Her. 3.10-15; Cícero. De Inv. 2.77; de Orat. 2.341-349; Part. 2.69-82).

297 Retórica. 1358b2; 1368a28. Ver também Quintiliano 3.4.2-3; ad Her. 1.2; Cícero. Inv. 1.7; de Orat. $1.141 ; 2.341$.

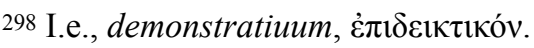

299 O elogio de testemunhas pode ser encontrado em Cícero: Ver. 5.57; Cael. 5; Clu. 197; Flac. 74 e 100.

300 Extenso discurso apresentado no senado em 55 a. C., contra Lúcio Calpúrnio Pisão Cesônio (cônsul em 58), algumas passagens podem ser encontradas em Ascônio.

301 Clódio atacou publicamente Cícero por seu testemunho no processo da Bona Dea. Cícero respondeu ao ataque no senado (Att. 1.16.8). Depois disso, Curião escreveu uma crítica contra Cícero, que a contestou em forma de panfleto repreendendo ambos: Curião e Clódio. Este panfleto foi publicado contra a vontade de Cícero, porque o considerava mal redigido (Att. 2.12.2 e 3.15.3). Quintiliano equivoca-se ao dizer que este discurso (perdido) foi apresentado em forma de sententia (5.10.92). 
3. Nem seria possível negar que neste gênero há matérias preparadas somente para uma exibição, como louvores a deuses e a homens de épocas passadas ${ }^{302}$. O que soluciona uma questão apresentada anteriormente ${ }^{303}$ e deixa claro que se equivocam os que consideram que um orador nunca discursará senão sobre uma questão duvidosa.

4. Ou será que os panegíricos a Jupiter Capitolino ${ }^{304}$, tema recorrente do Sacro Certame, são questões controversas? Ou não são também matéria do gênero oratório? Mas assim como um elogio empregado em assuntos particulares carece de demonstração, também aquele elaborado para exibição por vezes apresenta certa aparência de comprovação.

5. Por exemplo, um narrador que conta que Rômulo era filho de Marte e foi criado por uma loba ${ }^{305}$, para provar sua origem divina deverá usar os seguintes argumentos: que o menino jogado na correnteza de um rio não poderia afundar, que Rômulo fez tudo de um jeito tal que , que não seria inacreditável ser ele filho do deus da guerra, que os homens de sua época não duvidavam que ele próprio seria recebido no céu.

6. É certo que alguns argumentos até mesmo penderão para o lado da defesa, como o orador que ao elogiar Hércules justificasse ele ter trocado de roupas com a rainha da Lidia e, segundo a tradição, ter obedecido a ordem de fiar a lã ${ }^{306}$. Porém, é função do

\footnotetext{
${ }^{302}$ Costume que passou a vigorar na época de Augusto, e no período de Cláudio, ao invés dos deuses se elogiava o imperador.

3033.5 .3 .

304 Prática estabelecida por Domiciano no ano de 86 (Suetônio Dom. 4.8-9 :Instituit et quinquennale certamen Capitolino Iovi triplex, musicum, equestre, gymnicum et aliquanto plurium quam nunc est coronatum. Certabant enim et prosa oratione Graece Latineque...).

305 Ver 2.4.19.

306 Segundo a versão de Ovidio (Ep. 9.54-118), Dejanira repreende Hércules por ser escravo de Onfale, filha de Jardano e rainha da Lídia, e também por vestir-se como mulher e efetuar tarefas femininas. Na versão de Apolodoro (2.6.3), Hércules foi vendido a Onfale por Hermes, em retaliação pela morte de Ificles. A história de Hércules e Onfale aparece também em Sêneca, Her. F., 465 ss.
} 
elogio engrandecer e embelezar ${ }^{307}$. Sem dúvida, esta matéria tem muito a ver com deuses e homens, mas existe também louvor de outros animais ou até mesmo de seres inanimados ${ }^{308}$.

7. Em particular no caso dos deuses, o primeiro ponto que vamos venerar, de modo geral, é a majestade da sua natureza; depois, individualmente, seu poder e suas descobertas, que proporcionaram algo útil aos homens.

8. Será apresentado o domínio de cada um. Por exemplo, no caso de Júpiter, o poder de governar tudo; de Marte, sua força na guerra; no caso de Netuno, a autoridade no mar. Serão mostradas também as invenções, por exemplo: as artes, de Minerva; as letras, de Mercúrio; a medicina, de Apolo; o trigo, de Ceres; o vinho, de Baco. Na sequência, é preciso celebrar alguns de seus feitos que já entraram para a posteridade. Também glorificam os deuses os seus pais, por exemplo: se alguém é filho de Júpiter, seu passado venerável o engrandece, como no caso daqueles que são filhos do Caos; ou ainda os descendentes, como Diana e Apolo para Latona.

9. Alguns merecem louvores por terem nascido imortais; outros, porque ganharam imortalidade por próprio mérito. A piedade de nosso Imperador tornou essa glória também da época atual. ${ }^{309}$

10.O elogio de homens é mais variado. Primeiro, faz-se uma divisão em épocas: a que os precedeu, a que eles próprios viveram e a que se seguiu quando eles já cumpriram o seu destino. Antes do homem virão a pátria, seus pais e antepassados, e o

\footnotetext{
307 Aristóteles. Rh. 1.1368a 26; 1391b 33; 1417b 31. Cícero, Part. 71.

308 Aristóteles. Rh. 1366a 28.

309 Quintiliano refere-se ao imperador Domiciano, que divinizou seu irmão Tito. Suetônio (Dom.2) questiona a sinceridade do imperador em realizar tal apoteose. Para elogios de Quintiliano a Domiciano ver 4.proem. 2-5 e 10.1.91-92.
} 
tratamento conferido a eles é de dois tipos: será belo ter correspondido a sua nobreza ou ter abrilhantado com seus atos sua origem humilde.

11.Por vezes, serão apresentadas também informações sobre a época que precede a do homem elogiado, prenunciando sua glória futura, por meio da resposta de um oráculo ou augúrios ${ }^{310}$, por exemplo: quando se diz os oráculos anunciaram que aquele filho que nasceria de Tétis seria maior que seu pai. 311

12.O elogio do homem propriamente dito deve basear-se no seu caráter, no seu corpo e em elementos externos. É verdade que o elogio do corpo e aspectos fortuitos tem menor importância, mas nem por isso deve ser elaborado de um único modo. Às vezes enaltecemos verbalmente a beleza e a força física, como Homero faz com Agamêmnon $^{312}$ e Aquiles ${ }^{313}$; outras vezes a debilidade física pode despertar muita admiração, como quando o mesmo poeta diz que Tideo era pequeno de estatura, mas um grande guerreiro ${ }^{314}$.

13.Há ocasiões em que também a Fortuna confere distinção, como no caso de reis e príncipes (pois esta matéria é mais fértil para exibição de sua virtude). Por outro lado, quanto menores forem os recursos, maior a glória obtida com suas proezas. Mas todos os benefícios externos e os que couberam por acaso aos homens são louváveis, não porque dispunham deles, mas porque souberam utilizá-los de maneira honrosa.

310 Atribuir fenômenos sobrenaturais a um objeto humano, divinizando-o, é um recurso do elogio (Ver Isócrates. $E v$. 21). Tito Livio narra episódios de augúrios em Rômulo (1.7.1) e Numa (1.18.6-9) e o prodígio de Sérvio úlio (1.39.1-3). Além de personagens lendários, muitos imperadores romanos também eram relacionados a sinais divinos, como Júlio César (Suetônio, Iul.81.1-3) e Augusto (Suetônio, Aug. 97.1-3).

311 Profecia sobre o nascimento de Aquiles. Cf Apollod., 3.13.5.

312 Il. 2. 477.

313 Il. 2. 180.

314 Il. 5.801. 
14. Sem dúvida, as riquezas, o poder ou a influência — posto que aumentam em muito nossas forças - para bem e para mal são a mais segura demonstração de caráter: somos melhores ou piores por causa dessas coisas.

15.O elogio do caráter é sempre verdadeiro, mas não há apenas um caminho que leva a dizer isso. Em alguns casos, o mais elegante é seguir as etapas da vida de um homem e a sequência de suas realizações: por exemplo, nos primeiros anos seria louvada sua índole; em seguida, sua educação; e depois o conjunto de sua obra (isto é, o que ele fez e o que falou). Em outros casos, o melhor é dividir o elogio em tipos de virtudes: coragem, senso de justiça, autocontrole etc. e atribuir a cada uma as realizações que estiveram em conformidade com elas.

16. Decidiremos qual dos dois caminhos é o mais profícuo de acordo com a matéria, desde que se tenha em consideração que é muito caro à audiência o relato de um feito que uma pessoa ou foi a única ou a primeira a realizar, ou ao menos contando com pouca ajuda, e ainda de algo que supera toda expectativa e esperança ${ }^{315}$, sobretudo o que se fez mais por causa de outros do que por interesse próprio. ${ }^{316}$

17. Nem sempre cabe tratar do tempo subsequente à morte de um homem, não apenas porque às vezes são elogiados os que estão vivos, mas porque raramente se tem a ocasião em que é possível falar de honras divinas, decretos e estátuas erigidas às custas públicas.

\footnotetext{
315 Cf. Cícero, de Orat. 2.346-47.

316 Cf. Aristóteles, Rh. $1366 \mathrm{~b} 36$.
} 
18. Dentre tais temas, eu enumeraria monumentos do engenho admirados pela posteridade. Alguns, como Menandro317, obtiveram um reconhecimento mais justo dos pósteros do que em sua própria época. Os filhos outorgam fama a seus pais; as cidades, a seus fundadores; as leis, aos legisladores; as artes, aos inventores; bem como as instituições, aos seus criadores. Por exemplo, é atribuída a Numa a tradição de cultuar os deuses 318 e a Publícola319 a de abaixar os fasces diante do povo.

19. Toda esta série de argumentos se aplicará também ao vitupério, mas de forma inversa. É que, para muitos homens, uma origem infame foi motivo de vergonha, enquanto que para outros a própria nobreza de nascimento os tornou mais conhecidos por causa dos vícios e, consequentemente, mais odiados. Para alguns, como no caso de Páris ${ }^{320}$, foram profetizadas calamidades. Para outros, defeitos físicos ou má sorte, como Tersites $^{321}$ e Iro ${ }^{322}$, causaram desprezo, enquanto que os dons corrompidos pelos vícios levaram o ódio a certos homens, como quando nos foram apresentados pelos poetas um Nireu ${ }^{323}$ covarde e um Plístenes ${ }^{324}$ despudorado.

$317 \mathrm{O}$ autor de comédias não foi popular em sua época, obtendo apenas oito vitórias com as mais de cem peças compostas. Porém, logo após sua morte alcançou os iustiora iudicia, sendo imitado por Plauto, Cecílio, Névio, Terêncio, Turpílio e Atílio. Cf. Schmid-Stählin 2.1.40, citado por Taylor, (1971) pp. 336-7. Embora contemporâneos preferissem Filémon, Quintiliano considerava Menandro superior.(Quint. 10.1.72).

318 Ver Cícero, Rep. 2.26-27; Tito Lívio 1.17.1; 1.19.4; 1.20.1; 1.20.7; 1.21.3; 1.21.5.

319 Valério Publícola, filho de Sabino Vóleso, elevado a cônsul em 509, foi chamado publicola por instituir algumas medidas populares. Quando acusado de aspirar ao trono, convocou a assembleia e mandou inclinar diante dela as fasces, símbolos do poder, e subiu à tribuna. Com este ato quis demonstrar que o poder do povo se sobrepunha ao do cônsul. (Cícero, Rep. 2.53; Tito Lívio 2.7.7 ss.).

320 Quando estava gestante de Páris, Hecuba sonhou que dava à luz tochas. A interpretação do sonho foi que o bebê que iria nascer causaria a ruína da cidade, e por isso, deveria ser morto. (Apollod. 3.12.5).

321 Il. 2.212 ss.

322 Od. 18.1-106.

323 Il. $2.673-75$.

324 Plístenes pertence à linhagem de Tântulo. Segundo várias tradições pode ser fillho de Pélops, Atreu ou Tiestes, em outras aparece como pai de Agamémnon e Menelau. Exceto Quintiliano, não há outra referência ao seu comportamento indecoroso. 
20. Os vícios da alma são tantos quantas são as virtudes, e assim como os elogios podem ser tratados de duas formas. Alguns homens sofreram desonra após a morte, como Mélio ${ }^{325}$, que teve sua casa demolida, e Marco Mânlio ${ }^{326}$, cujo prenome foi abolido da família e nunca mais usado.

21. Também são repudiados os pais de homens perversos. É uma infâmia para os fundadores de cidades ter reunido um povo que causa desgraça a outros, como fez o primeiro fundador da superstição judaica ${ }^{327}$. As leis dos Gracos também foram odiadas $^{328}$, bem como qualquer precedente repugnante transmitido à posteridade por exemplo, a prática libidinosa em que o marido persa foi supostamente o primeiro a praticá-la com a mulher de $\operatorname{Samos}^{329}$.

22. Com relação aos vivos, o julgamento de outros homens também é uma espécie de sinal do caráter: a honra ou a ignominia confirma se o elogio ou o vitupério é verdadeiro.

23. Aristóteles, contudo, acha que faz diferença o lugar onde cada elogio ou vitupério são apresentados ${ }^{330}$. É de grande importância conhecer os costumes dos ouvintes, que tipo de argumentação funciona no público, para que acreditem estar presente naquele que será elogiado aquelas coisas que eles mais aprovam, e, naquele contra

\footnotetext{
325 Depois de destruída a casa, o lugar, situado abaixo do Capitólio, recebeu o nome de Aequimelium, para recordar a repressão a confabulações criminais (Liv 4.16.1). Além disso, por ordem de Quíncio Cincinato, Espúrio Mélio foi executado sob acusação de distribuir trigo e aspirar à tirania (Liv. 4.13-16).

${ }^{326}$ Devido à sua ambição de ser rei, Marco Mânlio foi condenado à morte (jogado da rocha Tarpeia) e, por decisão da família Mânlia, ninguém mais receberia o prenome Marco, eliminando a possibilidade de que ele fosse celebrado pelas gerações seguintes (Liv. 6.20.12-14).

327 Moisés (Tac. Hist. 5.2-5).

${ }^{328} \mathrm{~A}$ expressão perniciosae leges aparece algumas vezes entre os autores. Quintiliano expressa aqui a reputação que elas tinham.

329 Não há registros desta prática sexual.

330 Rh. $1.1367 \mathrm{~b} 7,3.1415 \mathrm{~b} 28$.
} 
quem falaremos, as coisas que eles odeiam, assim não haverá dúvida no julgamento porque este será anterior ao discurso.

24. É necessário, ainda, intercalar no discurso elogios constantes aos ouvintes (pois isso os torna benevolentes), e isso deve ser feito sempre que possível para ajudar na causa. Em Esparta, os estudos das letras serão menos apreciados que em Atenas, e muito mais a persistência e a coragem. Para alguns, é honroso viver do roubo; para outros, do respeito às leis. A frugalidade entre os sibaritas talvez seja algo desprezível. Entre os antigos romanos, a luxúria é o pior dos crimes331.

25. As mesmas coisas têm diferenças, dependendo do caso. Apresenta-se o mais favorável possível aquele juiz que acredita que o orador tem a mesma opinião que ele. Inclusive o próprio Aristóteles ${ }^{332}$ ensina - o que posteriormente Cornélio Celso $^{333}$ aplicou quase além da medida — que, posto haver uma certa vizinhança de vícios e virtudes, deve-se fazer uso de palavras com significados próximos. Por exemplo, devemos dizer "destemido" no lugar de "temerário", "generoso" em vez de "perdulário", "econômico" para "avarento". O que é válido também para o contrário. Seguramente um orador, isto é, um homem de bem, nunca fará tal coisa, a não ser que acaso seja levado a isso por interesse público.

26. Louvam-se cidades e homens de forma semelhante. Sendo assim, no lugar do pai está um fundador; a antiguidade lhe confere muita autoridade, como acontece àqueles que se diz terem nascido da terra ${ }^{334}$. Os vícios e as virtudes nas realizações

\footnotetext{
331 A ideia dos que "vivem do roubo" provavelmente é uma referência aos espartanos (cf. Xenofonte, Lac. 2.6-8; Plutarco, Lyc. 17-18.

332 Rh. 1.1367a32.

333 Médico das épocas de Augusto e Tibério, escreveu De Medicina e De Rhetorica, desse último restaram fragmentos. Acima citado 3.1.21.

334 Hermógenes, 18. 9.
} 
devem ter o mesmo tratamento que os indivíduos, sendo características próprias das cidades aquelas relacionadas a sua localização e fortificações. Os cidadãos dão brilho à sua cidade, assim como os filhos a seus pais.

27. Há ainda o elogio de obras públicas, quando se costuma destacar a grandeza, a utilidade, a beleza e o construtor. Por exemplo, a grandeza de um templo, a utilidade de uma fortificação, a beleza e o construtor em ambas obras. Também há o elogio de localidades, como a Sicília em Cícero ${ }^{335}$, quando admiramos igualmente a beleza e a utilidade: a beleza de lugares juntos ao mar, planícies e paisagens amenas, e a utilidade da atmosfera saudável e campos férteis. É possível haver ainda o elogio geral de "célebres palavras" ou "façanhas", bem como objetos de todo tipo.

28. Existem discursos com elogios ao sono e à morte, e inclusive a determinados alimentos $^{336}$, escritos por médicos. Sendo assim, por não concordar que este tipo de discurso - o laudativo - deva versar exclusivamente sobre a questão do que é honroso, considero que a maior parte da sua matéria está inserida na questão de qualidade, embora seja possível ocorrer os três tipos de questão. Cícero ${ }^{337}$ observou que César usou todos os tipos na sua inventiva contra Catão. Mas, no seu conjunto, o discurso epidíctico tem uma certa semelhança com o discurso deliberativo ${ }^{338}$, porque na maioria das vezes costumam ser as mesmas coisas que são recomendadas neste, elogiadas naquele.

\footnotetext{
335 Ver. 2.2 ss.; Orat. 210.

336 Cf. Plínio, Nat. 22.78.

337 Top. 94.
}

338 Aristóteles. Rh. 1367b37-39; Cícero, de Orat. 2.333. 


\section{CAPÍTULO 8}

[Da suasória e prosopopeia]

1. Surpreendo-me também com o fato de que alguns autores restringiram os discursos deliberativos exclusivamente à sua utilidade339. Ora, se fosse necessário propor um único objeto para eles, creio que o melhor seria adotar a recomendação de Cícero, que considera que esse tipo de matéria está relacionado sobretudo ao prestígio ${ }^{340}$. E não tenho dúvida de que aqueles que são da primeira opinião julgaram, segundo uma orientação mais nobre, que nem mesmo é útil aquilo que não é honroso.

2. Este princípio é o mais correto no caso de um conselho deliberativo que seja composto sempre por homens de bem e sábios ${ }^{341}$. Mas, diante de leigos (a quem muitas vezes é preciso apresentar nossa opinião), principalmente o povo, que em sua maioria é composto por homens incultos, é preciso fazer uma diferenciação e falar mais de acordo com a capacidade de compreensão do homem comum ${ }^{342}$.

3. Pois há muitas pessoas que pensam que até mesmo o que consideram honroso não é, ao mesmo tempo, útil o bastante; e, influenciados por uma aparência de utilidade ${ }^{343}$,

\footnotetext{
339 Aristóteles Retórica. 1358b22; 1362a18; Rhetorica ad Herennium 3.3; Cícero: De oratore 1.141; Partitiones oratoriae 83; Topica 91. No De inuentione (2.156), porém, Cícero propõe também a honestas como finalidade do discurso deliberativo.

${ }^{340}$ De oratore. 2. 334. Para Cícero, a dignitas envolveria também a honestidade. Ver De officiis 3.11.

${ }^{341}$ Aristóteles. Retórica. 1355a24ss.

342 Idem. 1355a27. Cícero e Quintiliano demonstram preocupação em adaptar o discurso à audiência: Cícero, Part. 90-42; Quintiliano, 2.17, 27-28; 12.10.51-53.

343 7.4.12.
} 
aprovam medidas inquestionavelmente vergonhosas, como no caso do tratado com

Numância ${ }^{344}$ ou a capitulação de Caudino ${ }^{345}$.

4. Tampouco basta restringir os discursos deliberativos ao status de qualidade ${ }^{346}$, que envolve questões sobre honra e utilidade, pois neles é comum haver também lugar para a conjectura. Algumas vezes emprega-se uma definição; em outras ocasiões podem incidir aí discussões legais, principalmente em deliberações privadas, quando não há certeza da licitude.

5. Da conjectura trataremos mais detidamente em breve. 347 Entrementes falaremos sobre a definição. Em Demóstenes temos: "Filipe deve ceder ou devolver Haloneso?”348; em Cícero, nas Filípicas, “o que é uma sublevação?”349. E ainda a questão sobre a estátua de Sérvio Sulpício ${ }^{350}$ não se pareceria àquela apresentada nos

\footnotetext{
344 O Cônsul Caio Hostílio Mancino, em 137 a.C., após derrota na Numância, propôs um tratado de paz como tentativa de salvar seu exército. O senado rejeitou o tratado e entregou Mancino aos inimigos. Os numancinos, no entanto, se recusaram a aceitá-lo e o devolveram. Caio Mancino recuperou sua cidadania e voltou a ocupar cargos públicos. Ver Cícero. Off. 3. 109. Ver também Quintiliano, 7.4.12.

345 Após a mal sucedida batalha das Forcas Caudinas, em 321 a.C.,os cônsules Tito Vetúrio e Espúrio Postúmio apresentam um acordo de paz com os samnitas, dando como garantia (sponsio) as vidas e bens do exército romano. Sem a aprovação do povo romano a referida paz foi recusada. (Cf. Liv., 9.2-6).

346 Taylor (1970) pp 356-7 chama a atenção para o fato de que a tentativa de Quintiliano em adequar o sistema de stasis à oratória deliberativa e epidíctica (3.7.28) é breve e contestável. Ao criar o sistema de stasis, Hermágoras parece não ter excluído nenhum tipo de discurso do referido sistema. Quintiliano, por sua vez, relaciona enfaticamente discursos judiciais com a teoria dos status. (Ver Livro 3. 11, Livro 7).
}

347 3.8.16-18.

348 Originalmente propriedade dos atenienses, a ilha de Haloneso foi ocupada por piratas, que Filipe expulsou. Quando os atenienses reivindicaram a devolução da ilha, Felipe negou-se a devolvê-la, posto que era sua propriedade, mas disse que estava disposto a presenteá-la aos atenienses. A autoria de mencionado discurso é questionável, mas Quintiliano considera como autor Demóstenes (Or. 7).

349 Phil. 8.2 ss.: Cícero tentou argumentar que havia um estado de guerra (bellum) entre Roma e Antônio, mas o senado não se convenceu e declarou tratar-se de uma rebelião (tumultus), classificando Antônio como inimicus e não como hostis. No seu discurso, Cicero, no entanto, deixa claro que o termo tumultus, define um distúrbio sério, de maior gravidade que uma guerra contra estrangeiros (bellum).

350 Sérvio Sulpício foi um dos três embaixadores enviados pelo senado ao campo de batalha de Mutina para negociar com Antônio. Sulpício morre nesta embaixada. Na nona Filípica (Fev. 43 a.C.) Cícero pede que o embaixador tenha não apenas o funeral pago pelo Estado, mas que seja erguida também uma estátua em sua homenagem. 
tribunais: "deve-se erigir estátuas exclusivamente para os que morreram em combate numa embaixada?"

6. Logo, a matéria deliberativa, igualmente denominada suasória ${ }^{351}$, delibera sobre o futuro, mas também questiona o passado.352 Tem duas funções: persuadir e dissuadir. ${ }^{353}$ Um proêmio, tal como os dos discursos judiciais, nem sempre é necessário, pois alguém já está benevolente com aquele a quem pede conselhos. 354 No entanto, o início do discurso deve ter uma aparência de proêmio, pois não se deve começar abruptamente, nem por onde quer que seja, porque em toda matéria existe algum ponto que naturalmente vem primeiro.

7. Para os discursos no senado e também os da assembleia popular, geralmente aplicase o mesmo princípio de granjear a benevolência dos ouvintes, adotado nos discursos judiciais. E não deve surpreender o fato de que inclusive nos panegíricos busca-se um ouvinte favorável, quando o benefício não consiste em nenhuma utilidade, somente no elogio.

8. É verdade que Aristóteles ${ }^{355}$ pensa - e não sem razão — que muitas vezes o exórdio nos discursos deliberativos baseia-se ou em nossa própria pessoa ou em nosso adversário (como se o tomássemos emprestado do gênero judicial), por vezes levando mesmo a crer que o assunto é menos ou mais importante do que ele

\footnotetext{
${ }^{351}$ Quintiliano emprega o termo suasoria em sua primeira acepção, ou seja, com significado de discurso deliberativo (2.4.25). Em Sêneca (Suas. 1.16) o mesmo termo designa um exercício da escola de retórica.

$352 \mathrm{O}$ caso de Sérvio Sulpício, $\S 5$, serve como exemplo de que no gênero deliberativo pode relacionar-se com o tempo passado também. O futuro como o tempo do gênero deliberativo. Cf. Quintiliano, 3.4. e; 7.4.2; Aristóteles. Rh. 1358b15; Cícero. Part. 10.62.

353 Os officia do gênero judicial são intentio e depulsio (3.9.1); do gênero laudativo, laus e vituperatio (3.7.1).

354 Cícero. Part. 13. A afirmação de Quintiliano de que no discurso deliberativo o público encontra-se previamente favorável ao orador aplica-se somente aos privata consilia (ver 3.8.15 abaixo), nos discursos públicos, porém, o proêmio é necessário para conquistar a benevolência. (3.8.7).
}

355 Rh. 3. $1415 \mathrm{~b} 33 \mathrm{ss}$. 
realmente é. Nos discursos demonstrativos, por sua vez, ele julga que os proêmios têm maior liberdade.

9. É que podem derivar tanto de um assunto distante, como fez Isócrates no Elogio de Helena ${ }^{356}$, quanto de um tema próximo, como no Panegírico ${ }^{357}$, quando lamenta que se concedam mais honras aos atributos do corpo do que aos da alma; também Górgias no Olímpico, ao elogiar os fundadores de tais jogos 358 . Aparentemente Salústio seguiu estes autores na Guerra de Jugurta e na Conjuração de Catilina, quando começou essas obras com exórdios que em nada dizem respeito à história359.

10.Mas agora volto ao discurso deliberativo. Nele, mesmo se utilizarmos um proêmio, deveremos contentar-nos com que seja bastante breve, não mais que uma espécie de cabeçalho introdutório. Uma deliberação privada, por seu turno, nunca exige uma narração dos fatos, contanto que seja um tema sobre o qual se há de emitir uma opiniãoa, porque todos sabem o que está em discussão.

11. Mas podem fazer parte de uma narração muitos aspectos que não estão relacionados com a deliberação. Nas assembleias populares muitas vezes é necessária também uma narração que informe a ordem dos eventos.

12.Este tipo de discurso exige o uso dos afetos ${ }^{360} \operatorname{como}$ em nenhum outro, pois muitas vezes é preciso apaziguar ou despertar a ira; incitar os ânimos ao medo, à cobiça, ao ódio, à reconciliação. Em algumas ocasiões é necessário ainda despertar a

\footnotetext{
356 Isócrates. Hel. 1-15.

357 Isócrates. Pan. 1-2.
}

358 Aristóteles. $R h .1414 \mathrm{~b} 21 \mathrm{ss}$.

359 Quintiliano entende que os prefácios de Salústio estão baseados nos proêmios do gênero epidíctico, como aparece em Isócrates e Gorgias. Esta análise, porém, é questionável: Taylor (1970), p. 365 explica que os prefácios de Salústio eram uma justificativa para o estilo de prosa que ele empregava nas suas monografias. Além disso, a situação política da época levava Salústio a escolher a obscuridade e a brevidade do estilo de Tucídides (Leeman (1963) pp. 184-187, apud Taylor (1971)).

360 Cícero, de Orat. 2.337. 
compaixão, seja porque será preciso convencer a levar auxílio aos sitiados, seja porque lamentaremos a destruição de uma cidade aliada. Nas deliberações, porém, o que mais vale é a autoridade do orador.

13.Deve não apenas ser o mais sensato e honesto, como também parecê-lo, quem quiser que todos creiam em sua opinião sobre o que é útil e honroso. Nos tribunais é habitualmente considerado legítimo o orador deixar-se levar pelas suas inclinações ${ }^{361}$. Ninguém há de negar que os conselhos são dados de acordo com os princípios morais.

14.A maioria dos gregos julgou que essa função do discurso concional como um todo restringe-se às assembleias populares 362 e a destinou exclusivamente à administração pública. Inclusive Cícero ${ }^{363}$ dedica particular atenção a esta parte. É por isso que ele defendeu que aqueles que deliberam sobre a paz, a guerra, as tropas, as obras públicas ou os impostos, conheçam profundamente dois aspectos: as forças da cidade e seus costumes, de modo que o método da deliberação esteja fundamentado tanto na natureza da própria circunstância quanto na audiência.

15.De minha parte, no entanto, me parece que a realidade é mais complexa, pois existe enorme variedade tanto de pessoas que querem conselhos quanto de conselhos que podem ser dados. Por isso, para persuadir e dissuadir, antes de mais nada é preciso

\footnotetext{
361 Cícero, Off. 2.51.

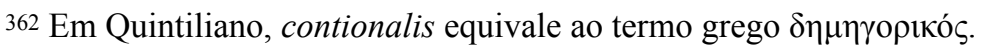

363 Provável referência ciceroniano para Quintiliano foi de Orat. 2.333, 334, 337.
} 
ter em mente três pontos: sobre o que se delibera ${ }^{364}$, quem são os que deliberam ${ }^{365}$, e quem é que dá o conselho ${ }^{366}$.

16.Ou é certo ou é incerto que o fato sobre o qual se delibera é factível. Se é incerto, esta será a única ou pelo menos a principal questão. Muitas vezes acontecerá de primeiro falarmos que, ainda que seja factível, não devemos fazê-lo, e sem seguida, falarmos que não é factível. Quando é isso que se investiga, temos uma conjectura367. Por exemplo: o Istmo ${ }^{368}$ deve ser aberto? O pântano de Pontino ${ }^{369}$ deve ser drenado? É possível construir um porto em Ostia370? Alexandre encontrará terras para além do Oceano? $?^{371}$

17.Mas também nos casos em que for sabidamente factível, haverá por vezes uma conjectura. Por exemplo, quando se pergunta se os romanos irão vencer Cartago de qualquer maneira, se Aníbal retornará no caso de Cipião transferir seu exército para a África ${ }^{372}$, ou se os samnitas vão manter sua palavra se os romanos depuserem suas

\footnotetext{
364 Aristóteles. (Rh. 1356a3). Quid sit de quo deliberetur é um dos três pontos que constituem a base do capítulo 8 e relaciona-se com a função de docere (ver 3.5.2).

365 qui sint qui deliberent refere-se ao caráter da audiência (Aristóteles, Rh. 1388b31-1391b6 e 1378a6 ss.) e tem a função de delectare.

366 Referência ao orador, juntamente com a audiência faz parte das provas éticas apresentadas por Aristóteles (citado na nota anterior). A impressão causada pelo orador, na qual também está implicada uma análise da audiência, é um recurso de manipulação dos sentimentos dos ouvintes.

367 Embora aqui Quintiliano não esteja tratando dos estados de causa no gênero deliberativo, as questões apresentadas como exemplo de conjectura pertencem ao status conjectural (ver 3.5.56-61).

${ }^{368}$ O ístmo de Corinto. Projeto de Nero (Suetônio. Nero, 19) construído entre os anos de 1881 e 1893.

$369 \mathrm{Na}$ época republicana tentou-se drenar o pântano. Tentativa repetida mais tarde por Trajano. A drenagem somente foi concluída por Mussolini (1932-1939).

370 Ver 2.21.18

371 Ver Sêneca. Suas. 1.

372 Ver Liv. 28.40-45 (discursos de Fábio e Cipião).
} 
$\operatorname{armas}^{373}$. Em determinados casos é crível que não apenas são factíveis mas também que vão acontecer, mas em outra circunstância, em outro lugar, de outro modo.

18.Quando não houver lugar para a conjectura, outros aspectos devem ser considerados. Primeiro será deliberado ou sobre o próprio tema sobre o qual se pedem opiniões ou sobre outras causas que, embora externas, têm influência na causa. Um exemplo do primeiro caso: "os senadores deliberam se instituir um pagamento aos soldados" 374.

19.Esta matéria será simples. A ela se somam razões para fazer algo, por exemplo: "os senadores deliberam se entregar os Fábios aos gauleses, que ameaçam fazer guerra" 375 , ou para não fazer: "Gaio César delibera se deve insistir no avanço contra a Germânia, em um momento em que em toda parte os soldados fazem testamentos" 376 .

20.Estas suasórias são duplas. No primeiro caso, o motivo da deliberação é que os gauleses ameaçam fazer guerra; além desse, pode haver outro motivo de deliberação: se é preciso entregar os Fábios mesmo sem tal ameaça de guerra, porque eles foram enviados como embaixadores, travaram um combate ilegalmente e mataram o rei com quem negociariam.

21.No segundo caso, César, sem dúvida alguma, não teria que decidir nada, não fosse essa comoção de seus soldados. É o caso, entretanto, de pergunta se, independente das circunstâncias, seria oportuno invadir a Germânia, mas sempre vamos falar

\footnotetext{
373 Referência às forcas caudinas, $\S 3$.

374 Ver Liv. 4.59.11.

375 Ver Liv. 5.35.5 - 5.36.11.

376 Ver César, Gal. 1.39.
} 
primeiro daquilo sobre o que é possível deliberar, mesmo que deixemos de lado as consequências. 377

22.Alguns rétores julgaram que são partes do aconselhamento o honroso, o útil e o necessário. Para esta terceira parte eu não encontro lugar. Seja qual for a pressão que sobrevenha, talvez seja preciso aguentar um pouco, não fazer nada. E se delibera sobre o que deve ser feito.

23. Se eles denominam necessidade aquela situação a que as pessoas se vêem obrigados por temer o pior a questão será de utilidade. Por exemplo, se sitiadas e numericamente inferiores, com pouca água e alimento, deliberam se fazer a rendição ao inimigo e dizem: “é necessário” e, a seguir — o que sem dúvida será entendido — “caso contrário vamos morrer". Justamente pelo fato de poder ser preferível morrer, não há a necessidade de render-se. Para exemplificar, não fizeram isso os habitantes de Sagunto ${ }^{378}$ nem os homens que ficaram cercados em seu barco em Optérgio ${ }^{379}$.

24.Portanto, também nestes casos a questão consistirá exclusivamente na utilidade ou será dividida entre o útil e o honroso. "Mas se um homem deseja ter filhos é necessário que ele encontre uma esposa" Quem duvida? Porém, é necessário que fique claro para o homem que quer ser pai que ele tem que se casar.

25.Assim sendo, me parece que não há sequer deliberação quando há necessidade, e não mais do que quando é certo que algo não é factível — uma vez que toda deliberação é sobre fatos incertos. Fizeram melhor portanto, os que consideraram aquela terceira

377 Detractis sequentibus pode ser entendido como um segundo ponto de deliberação, pois Quintiliano está falando das suasórias dúplices (3.8.29), o ponto principal é se a invasão da Germânia vale a pena e deve ser considerado independente do segundo. Cf. ad Her. 3.2: Item deliberationes partim ipsae propter se consultadas sunt... partim propter aliquam estraneam causam.

378 Provavelmente Quintiliano tomou por base a descrição de Tito Livio sobre o assédio e tomada de Sagunto (Liv. 21.11.3 - 21.15.2) por Aníbal (219 a.C.).

379 Em 49 a.C., durante a guerra civil, milhares de homens de Opitérgio (atual Oderzo, no Veneto) preferiram morrer a serem capturados pelo exército de Pompeu. (Florus 2.13.33). 


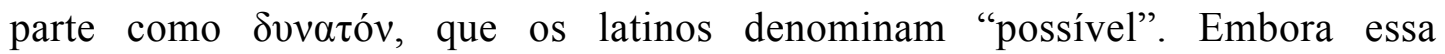
denominação soe estranha, é a única que temos. 380

26.É evidente demais, para que eu tenha que demonstrá-lo, que essas três partes não ocorrem em todo discurso deliberativo. A maioria dos autores, porém, as apresenta em um número maior, mas na verdade são subdivisões das partes já mencionadas. Desse modo, o direito, a justiça, a piedade, a equidade, bem como a brandura (pois

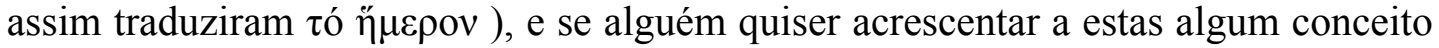
do mesmo gênero, todos estarão inseridos na ideia de honra.

27.Se algo é fácil, importante, agradável, seguro, é uma questão de utilidade. Tais tópicos nascem da contradição: é útil, mas "difícil”" ou “insignificante" ou “desagradável” ou "perigoso".

28.Alguns creem, porém, que por vezes a deliberação tem a ver apenas com o bemestar, como se se deliberasse sobre construir um teatro ou instituir jogos. Mas eu não acho que alguém esteja tão tomado pelo luxo a ponto de não buscar em um aconselhamento nada além do prazer.

29.Pois bem, sempre é necessário que haja algo maior. Como, por exemplo, nos jogos a honra aos deuses; na construção do teatro, o produtivo descanso do trabalho; se não existir teatro, o degradante e nocivo distúrbio da multidão; e até mesmo na própria religião, quando chamarmos teatro um tipo de templo de tal ritual sagrado.

30.Na verdade, dizemos muitas vezes que a utilidade deve ser deixada de lado para que façamos o que é honroso, por exemplo, quando aconselhamos àqueles homens de Optérgio não se renderem aos inimigos, ainda que possam morrer se não o fizerem;

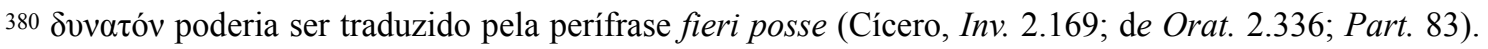
Taylor (1971), p.375 informa que o termo possibile era relativamente novo na época de Quintiliano e ocorria aqui pela primeira vez num texto extenso. 
outras vezes preferimos a utilidade ao invés da honra, como quando recomendamos que se armem os escravos na guerra púnica. 381

31.No entanto, neste último caso não devemos admitir abertamente que se trate de algo desonesto (pois é possível alegar que, por natureza, todos os homens são livres, feitos da mesma matéria, e que os escravos talvez sejam oriundos de uma estirpe antiga e nobre) ${ }^{382}$. No primeiro caso, em que é evidente o perigo, é preciso contrapor outros argumentos, como afirmarmos que terão uma morte ainda mais cruel em caso de rendição, seja porque o inimigo não manteve a palavra, seja porque César venceu, o que é mais plausível.

32.Mas estes casos, que são tão conflitantes entre si, na sua maioria costumam ser contornados por meio da denominação empregada. De fato, até mesmo a utilidade é atacada por aqueles que dizem não apenas que a honra é mais importante que a utilidade, mas que nem mesmo há utilidade naquilo que não é honroso. Por outro lado, com sentido contrário, o que nós dizemos ser uma honra, outros chamam vaidade, ambição, estupidez, mais aceitáveis por conta das palavras do que dos fatos.

33.E as coisas úteis não são comparadas somente com as inúteis, mas também entre si.

Por exemplo, se temos duas opções, em uma escolhemos o que é mais útil, em outra, o que é menos ${ }^{383}$. Pode haver acréscimos, também ocorre por vezes deliberações

\footnotetext{
381 Liv. 22.57.11.

382 Comparar Sêneca Ep. 47. 10-12; Horácio Carm. 2.4.13-14.

383 Cícero, de Orat. 2.333-341.
} 
tríplice ${ }^{384}$ : como quando Pompeu decidia se iria à Partia, à África ou ao Egito ${ }^{385}$.

Neste caso, a questão não está somente no que é o melhor, mas no que é o melhor entre todas as opções, acontecendo o mesmo no caso contrário.

34.Neste gênero de matéria nunca haverá dúvida sobre a proposição que nos é inteiramente favorável, pois onde não há lugar para contradição, o que poderia ser motivo de dúvida? Assim praticamente todo discurso deliberativo nada mais é que uma comparação ${ }^{386}$; temos que examinar o que vamos ganhar e como, de modo que seja possível avaliar se haverá maior vantagem naquilo que buscamos ou desvantagem no modo como tentamos obtê-lo.

35.A questão de utilidade envolve também o tempo: “é vantajoso, mas não agora”; o lugar: "não aqui"; a pessoa: "não para nós", "não contra estes"; o modo de agir: “assim não"; a medida: "não em tal dimensão". Mas, com relação à pessoa ${ }^{387}$, muitas vezes levamos em consideração o decoro, que deve ser observado tanto em nós quanto naqueles que deliberam.

36.Por conseguinte, por mais que os exemplos tenham muito peso nos discursos deliberativos, porque os homens são mais facilmente levados a dar seu consentimento através da experiência, também é importante saber de quem é a

\footnotetext{
384 Diferentemente da materia simplex (3.8.18) e da suasoriae duplices (3.8.20), aqui a suasoria triplices aborda três questões independentes que devem ser debatidas, no exemplo dado, o único elemento em comum é a pessoa de Pompeu. No Da Invenção (1.17), Cícero divide as causas deliberativas em "simples" (equivalente a simplex em Quintliano) e "complexas", esta última a abarca duas modalidades: uma decisão sobre dois pontos (a comparativa, que Quintiliano explica como ut si duobus eligamus (3.8.33), sem nome específico) ou uma decisão sobre várias opções (triplices suasoriae em Quintiliano). Note-se que a suasoriae duplices não tem correspondente em Cícero.

385 Ver discurso de Pompeu em Lucano 8.262-327.

386 Estreitamente relacionado com o que foi dito anteriormente sobre o necessarium (3.8.22). Somente é possível haver debate se existirem boas alternativas de ação: decide-se o que é melhor ou o que é melhor de todos. Ver ad Her. 3.2. Sobre graduações do bem, ver Aristóteles, Rh. $1363 \mathrm{~b} 5$ ss.

387 Neste ponto Quintiliano deixa de lado a matéria deliberativa e volta a atenção para o caráter da audiência (3.8.35-47) e do orador (3.8.48-54).
} 
autoridade em questão e a quem se dirige, pois é variada a disposição dos que deliberam. Há dois tipos.

37.Pode ser ou um grupo ou apenas uma pessoa que pede conselhos, mas em ambos casos existem diferenças. Se for um grupo, faz muita diferença se é o senado ou o povo, se são romanos ou cidadãos de Fidenas ${ }^{388}$, se gregos ou bárbaros; no caso de uma única pessoa, devemos persuadir Catão ou Gaio Mário a que concorram a um cargo público, ou que decida Cipião, o Velho, ou Fábio sobre estratégias de guerra ${ }^{389}$.

38.Igualmente deve-se respeitar o sexo, a posição, a idade, mas principalmente o caráter é decisivo. É muito fácil fazer propostas honestas a pessoas honestas. Por outro lado, se tentamos que pessoas inescrupulosas optem por uma atitude correta, é preciso ser cauteloso para não parecer que desaprovamos seu estilo de vida peculiar.

39.A disposição de quem delibera, porém, deve ser sensibilizada não pela natureza do que é honroso, a qual ele não leva em conta, mas através de elogios, da opinião pública, e — se estas futilidades fazem pouco efeito - por vantagens futuras. E ainda é possível ir um pouco mais longe, incutindo-lhes alguns temores, no caso de agirem de modo diferente.

40.Pois, além do fato das índoles mais fracas serem facilmente aterrorizadas, talvez até por natureza, para a maioria o temor do mal tem mais importância que a esperança do bem; da mesma forma para essas pessoas é mais fácil a compreensão das coisas torpes do que a das coisas honrosas.

\footnotetext{
388 Segundo Horácio (Ep.1.11.8) esta antiga cidade latina era o exemplo de insignificância.

389 Em nota ad locum, D.A.Russel (p.134) mostra quatro tipos de caráter apresentados nessas personalidades: Catão, o rigoroso moralista; Mário, o oportunista ambicioso; Cipião, destemido; Fábio, cauto.
} 
41.Por vezes também se recomendam procedimentos pouco decorosos a pessoas de bem, e a pessoas pouco honradas são dados conselhos, nos quais se observa a vantagem das próprias pessoas que pedem os conselhos. Sei muito bem o que poderia ocorrer de imediato ao leitor: "Então é isto que você está ensinando? E acha justo?"

42.Poderia me redimir Cícero, que assim escreve a Bruto 390 , depois de apresentar muitas propostas que poderiam honradamente ser feitas a César ${ }^{391}$ : “eu seria um homem bom se desse tais conselhos? De modo algum. O objetivo de um discurso deliberativo é a vantagem para aquele que se tenta persuadir. Mas estas coisas são certas!? Sem sombra de dúvida. Nem sempre existe espaço para o certo no ato de persuadir”. Não obstante, por tratar-se de assunto muito profundo e não estar apenas relacionado a discursos deliberativos, vou deixar este tema para o livro doze, que será o último ${ }^{392}$.

43.Na verdade eu não gostaria que se fizesse nenhuma torpeza, mas consideremos momentaneamente que isso esteja ligado a exercícios escolares, pois é preciso saber como se constrói a injustiça para que defendamos melhor o que é justo.

44.Enquanto isto, se alguém vai tentar convencer uma pessoa de bem sobre algo desonroso, que se lembre de não apresentá-lo como tal (do mesmo modo como alguns declamadores incitam Sexto Pompeu ${ }^{393}$ a praticar pirataria justamente por se tratar de algo torpe e cruel), mas é preciso aplicar a esta ação vergonhosa um

\footnotetext{
390 Cícero, Brut. frag. 6 Watt.

391 I.e., Otaviano.

392 Ver 12.12 .

393 Ver Lucano 6.420-422.
} 
colorido, inclusive em se tratando de pessoas perversas - posto que ninguém é tão mal a ponto de querer aparentar sê-lo!

45.Sendo assim, Catilina, em Salústio ${ }^{394}$, fala de uma maneira que ele parece ousar cometer uma ação extremamente criminosa não por maldade, mas por indignação. No mesmo sentido, Atreu, na tragédia de Varo395, diz: “Já sofro o que há de mais abominável, agora sou forçado a agir”. Como precisam preservar mais ainda esta espécie de fachada aqueles que têm que cuidar da sua reputação!

46.Em razão disso, se aconselharmos Cícero a pedir desculpas a Antônio, ou até mesmo a queimar sua Filípicas (caso Antônio lhe garanta a vida), não alegaremos o amor à vida (se isso tem importância para ele, continua a tê-lo ainda que não falemos nada), mas o exortaremos a se salvar pelo bem da República ${ }^{396}$.

47.Ele precisa de tal pretexto para que não se envergonhe de tais súplicas. E quando aconselharmos Gaio César a aceitar tornar-se rei ${ }^{397}$ enfatizaremos que não há como a república continuar de pé se não pelo governo de uma única pessoa. Porque aquele que decide sobre uma ação criminosa deseja somente uma coisa: que o seu delito pareça ser o menor possível.

48.O caráter daquele que aconselha também tem muita importância, pois geram expectativas a sua idade e sua fortuna, se tem um passado ilustre, uma estirpe nobre. Deve-se tomar cuidado para que o que se diz a respeito dele não esteja em desacordo com o que ele próprio diz. Para que não haja contradição, recomenda-se uma

\footnotetext{
394 Cat. 20.

395 Tiestes. No enredo, Atreu, rei de Micenas, após ser enganado por seu irmão Tiestes - que seduziu sua esposa e usurpou o reino - matou os filhos de Tiestes e os serviu em um banquete ao irmão.

396 Para abordagens desse tipo de suasória, ver Sêneca Suas. 6 e 7.

397 O reino foi oferecido a César nas Lupercálias em 44 (Plutarco, Caes. 61). Para Quintiliano a aceitação teria sido um crime. Ver também 9.3.61.
} 
abordagem mais humilde, pois o que é liberdade para alguns, outros chamam de libertinagem; enquanto para alguns basta a autoridade, outros mal conseguem defender-se pelo mero uso da razão.

49.Em razão disso, para mim o mais difícil são indiscutivelmente as prosopopeias ${ }^{398}$, porque, além dos critérios exigidos no discurso deliberativo, há ainda a dificuldade da construção de uma personalidade. E neste caso, César, Cícero, Catão recomendariam a mesma coisa, cada um de uma modo diferente. Este exercício, em particular, é extremamente útil, seja porque exige um esforço dobrado, seja porque oferece muito material também aos futuros poetas e historiadores, e, sem dúvida alguma, é necessário aos oradores.

50.Muitos foram os discursos compostos, por gregos e latinos, para que fossem apresentados por outros, cujo conteúdo devia ser adaptado à vida e à posição social do orador. Será que Cícero pensava do mesmo modo ou assumia a mesma personalidade quando escreveu para Gneu Pompeu, para Tito Âmpio ou para outros $^{399}$ ? Acaso ele não levava em consideração individualmente a fortuna, a posição, as realizações de todos aqueles a quem ele emprestava sua voz e ainda compunha uma imagem para que discursassem melhor, sim, mas parecessem eles próprios os autores dos discursos?

51.0 discurso que destoa da pessoa é tão defeituoso quanto o que destoa do assunto ao qual deveria se adequar. É por isso Lísias conseguia brilhantemente preservar o

\footnotetext{
398 Embora o sentido mais comum do termo seja o de "personificação", ou seja, ação de dar voz a uma pessoa ausente ou objeto inanimado (cf.Lausberg, (1993) § 425), nesta passagem Quintiliano o utiliza para designar uma suasória, um exercício no qual o orador assume o papel de outra pessoa. Ver também 2.1.2.

399 Discursos desconhecidos, mas em Carta a Ático (8.17.2), Cícero relata que Pompeu contratou alguém para escrever uma carta pública a César, e em Carta ao Irmão Quinto (3.8.54), ele conta que escreveu uma consolação para Serrano Doméstico sobre a morte do seu irmão.
} 
realismo nos discursos que escrevia para homens incultos ${ }^{400}$. A verdade é que cabe sobretudo aos declamadores levar em consideração o que convém à cada personalidade, eles que tratam de raríssimas controvérsias à maneira dos advogados. $\mathrm{Na}$ maioria das vezes eles se apresentam como filhos, pais, homens ricos, idosos, severos, indulgentes, avarentos, enfim supersticiosos, medrosos, debochados. Dificilmente atores de comédia401, ao atuar, precisam conciliar tantas facetas quanto eles, ao discursar.

52. Tudo isso pode ser entendido como prosopopeia e eu o relaciono com a suasória porque uma se diferencia da outra somente no que diz respeito à pessoa — ainda que algumas vezes as prosopopeias sejam empregadas também nas controvérsias, tomando como base outras histórias e envolvendo nomes conhecidos de oradores.

53.Eu sei que em sua maioria, as prosopopeias poéticas e históricas são apresentadas como exercícios; por exemplo, as palavras de Príamo para Aquiles ${ }^{402}$, ou as de Sula renunciando à ditadura na assembleia popular. Mas elas incidirão em algum dos três gêneros em que dividimos as causas, pois costumamos suplicar, denunciar, prestar contas e outras ações, acima mencionadas ${ }^{403}$, que normalmente são apresentadas de forma variada e conforme exigência do assunto, como matéria judicial, deliberativa ou demonstrativa ${ }^{404}$.

\footnotetext{
400 Enquanto em Roma havia a figura do defensor, nos tribunais gregos os réus mesmos tinham que apresentar suas defesas, por causa disso eram muito comum os logógrafos, como Lísias. (Dionísio de Halicarnasso, Lys. 8-9). Ver também Institutio oratoria 11.4.17.

401 Mais à frente (10.1.71), quando trata da declamação, Quintiliano relaciona os personagens da comédia com os papéis dos declamadores escolares. Em outra passagem (11.1.38), ele fala da utilidade de construir personagens, tanto para logógrafos como para declamadores, e a relação disso com o drama.

402 Quando Príamo vai à tenda de Aquiles para resgatar o cadáver de Heitor. (Il. 24. 477 ss.).

403 Ver 3.4.3.

404 Ver 3.8.6.
} 
54.Na verdade, é extremamente frequente empregarmos discursos fictícios de pessoas que colocamos para falar por nós. Como em Cícero, na Defesa de Célio 405 , quando se dirigem a Clódia tanto Apio Cego quanto Clódio, irmão dela — o primeiro condenando seus vícios; o segundo exortando a eles.

55.É costume nas escolas inventar temas para discursos deliberativos, muito semelhantes às controvérsias, e que são uma combinação de dois gêneros. Por exemplo, uma consulta a Gaio César sobre o castigo a ser imposto a Teodoto ${ }^{406}$. É certo que esta causa é composta de acusação e defesa, o que é característico dos discursos judiciais, mas também envolve um procedimento de utilidade:

56. Teria sido o assassinato de Pompeu vantajoso para César? ou deveria se temer uma guerra com o rei se Teodoto fosse morto? E naquele momento não seria uma guerra extremamente inoportuna, perigosa e certamente longa?

57.Há ainda a questão sobre o que é honroso: seria digno de César vingar Pompeu? Ou seria para temer que a causa de sua facção piorasse se ele reconhecesse que Pompeu não merecia a morte?

58.Este tipo de questão pode aparecer também em casos reais. Acerca das suasórias, porém, não foram poucos os erros cometidos pela maioria dos declamadores - eles estimaram que as suasórias eram um gênero oratório distinto e inteiramente oposto ao judicial. Impuseram inícios abruptos e um discurso sempre afetado, excessivo em

\footnotetext{
405 Cael. 33-36.

406 Seneca, nas Controvérsias (2.4.8), relata uma suasória proposta por Latrão: após sua derrota na batalha de Farsália, Pompeu fugiu para o Egito, onde foi morto por ordem do rei Ptolomeu XIV (este aconselhado pelo grego Teodoto). Conta-se que foi visível a decepção de César quando ele chegou ao Egito (Plutarco. Caes. 48, Pomp. 80). O cenário da declamação é um adorno artificial. (nota de Russell, p.142).
} 
palavras e, como eles mesmos dizem, sofisticado; em todo caso empenharam-se em fazer observações mais breves sobre esse exercício do que as da matéria legal407.

59.Além disso eu entendo que não é indispensável haver um proêmio para a suasória, pelos motivos expostos anteriormente408; assim eu não vejo por que se deveria começar uma declamação num tom ensandecido: uma vez apresentada a consulta, a pessoa questionada a dar sua opinião, se for equilibrada, não deve gritar, mas buscar conquistar o assentimento de quem o consultou com uma abordagem a mais humana e civilizada possível.

60.Por que, ao dar sua opinião, essa pessoa deveria fazer um discurso inflamado e o tempo todo afetado, quando as decisões exigem sobretudo moderação e razão? Eu não vou negar que nas controvérsias é muito comum que a impetuosidade dos discursos seja amenizada no proêmio, na narração ou na argumentação. Se deixarmos tais partes de lado, sobrará o que realmente constituem as suasórias, porém mesmo nestas o tom é mais homogênio, não tão furioso e violento.

61.Por outro lado, nas suasórias os declamadores não devem buscar o esplendor das palavras, mas isso é o que mais acontece. Pois os que inventam esses exercícios quase sempre gostam muito de personagens extremamente grandiosas - reis, imperadores, senadores, o povo - e de temas pomposos; assim as palavras, estando à altura do assunto, reluzirão pelo próprio brilho da matéria.

62.Nas deliberações reais o método é outro. É por isso que Teofrasto ${ }^{409}$ pretendia que a linguagem do gênero deliberativo deveria ficar o mais distante possível de qualquer

\footnotetext{
407 Cf Sêneca, Con. 2, pr.1; Tácito, Dial. 25; também Quintiliano, 8, pr.18; 8.3.6; 12.10.79. 408 3.8.6.

409 Ver 3.1.15.
} 
afetação. Neste ponto, ele segue a autoridade de seu professor, embora costume discordar dele sem receio.

63.Efetivamente, Aristóteles ${ }^{410}$ considerava que a linguagem do discurso epidíctico era a mais apropriada para a escrita; em segundo lugar viria a do gênero judicial. Evidentemente porque a primeira relaciona-se inteiramente com ostentação, a segunda requer arte, inclusive para enganar, se assim exigir a utilidade, ao passo que as deliberações se sustentam na credibilidade e na prudência.

64.Em relação a esses pontos da matéria demonstrativa, estou de acordo (de fato, todos os outros escritores ensinaram o mesmo). No que diz respeito aos gêneros judicial e deliberativo, porém, eu creio que o método de discursar depende propriamente das circunstâncias do tema a ser tratado ${ }^{411}$.

65.Assim observo que as Filipicas de Demóstenes se sobressaem pelas mesmas virtudes empregadas nos discursos judiciais. Também os pronunciamentos de Cícero, no Senado e nas assembleias populares, ostentam tanto brilho oratório quanto seus discursos de acusação e defesa. No entanto, o mesmo Cícero fala sobre a suasória da seguinte maneira: "o discurso como um todo deve ser simples e sério, mais ornado pelas ideias que pelas palavras" 412 .

66. Quase todos autores concordam, com razão, que o uso de exemplos é altamente recomendável nesta matéria, mais que em nenhuma outra, porque, na maioria das vezes, ocorrências futuras parecem corresponder a fatos passados, e de certa forma a experiência é considerada como evidência de razão ${ }^{413}$.

\footnotetext{
410 Rh. 3.12, $1413 \mathrm{~b} 3$ ss.

411 Em 8.3.11-14, Quintiliano, falando do ornamento, retoma a questão da adaptação ao estilo ao tema.

412 Part. 97.

413 Aristóteles, Rh. 1368a 29, 1394a 8, 1418a 1; ad Her. 3.9; Cícero, Part. 96.
} 
67.Também brevidade ou a abundância são determinadas não pelo gênero mas pela importância da matéria. Tal como a questão em geral é mais simples nas deliberações, muitas vezes ela é menos importante nas causas forenses. Comprovará que tudo isso é verdade quem preferir ler não apenas discursos, mas obras históricas (nestas, a maioria dos discursos na assembleia e os pronunciamentos no Senado cumprem a função de persuadir ou dissuadir), em vez de definhar sobre os manuais dos rétores.

68.É que não encontrará inícios abruptos nos discursos deliberativos; nos judicias pode encontrar não raro um tom muito mais afetado, e em ambos os gêneros, o uso de palavras apropriadas ao assunto. E algumas vezes ainda pode deparar-se com discursos judiciais mais breves que os pareceres dados no Senado.

69.Com toda certeza nestes discursos ele não vai encontrará os erros pelos quais alguns declamadores penam, quando desrespeitosamente acusam os que defendem pontos de vista contrários, discursando como quem discordasse totalmente dos que estão deliberando, parecendo por isso antes repreender que aconselhar.

70.Os jovens devem saber que isso foi escrito para eles, para que não procurem exercitar-se de uma maneira diferente daquela que vão discursar e não percam tempo com práticas a que terão de desabituar-se depois. De qualquer forma, quando começarem a ser chamados pelos amigos para participar em consultas, para dar um parecer no Senado ou ainda para dar um conselho — se o imperador assim o pedir — eles aprenderão na prática algo em que talvez não acreditassem quando lhes era ensinado. 


\section{CAPÍTULO 9}

[As partes das causas judiciais]

1. Passemos agora ao gênero judicial, que é especialmente complexo, mas tem como base duas funções: acusar e defender. Suas partes, de acordo com a maioria das autoridades, são cinco: proêmio, narração, comprovação, refutação, peroração. Alguns acrescentaram ainda partição 414 , proposição415 e digressão416; dessas, as duas primeiras substituiriam a comprovação ${ }^{417}$.

2. Sem dúvida nenhuma, é necessário propor o que se vai provar, mas também concluir: por que então a proposição é parte da causa, e a conclusão, não? Na verdade, a partição é um tipo de disposição. Por sua vez, a disposição é uma parte da retórica ${ }^{418}$ e se estende igualmente por todas as matérias e a organização do discurso, assim como a invenção e a elocução.

3. Eis por que ela não deve ser considerada apenas uma parte do discurso inteiro, mas também parte de questões individuais. Efetivamente, em qual questão o orador poderia não indicar o que ele vai dizer em primeiro, em segundo ou terceiro lugar? E isto cabe à partição. Como é ridículo, isso sim, fazer de uma questão um tipo de prova, e denominar a partição, que é um aspecto da questão, uma parte do discurso no geral!

\footnotetext{
${ }^{414}$ A partitio é analisada em 4.5.1-28.

415 Quintiliano discute a propositio em 4.4.1-9.

$416 \mathrm{O}$ excessus (digressio, egressio, egressus ou excursus) é a parte do discurso tratada em 4.3.1-16).

417 No Orador (122), Cícero propõe as mesmas cinco partes apresentadas por Quintiliano, no $D a$ Invenção (1.19), ele acrescenta uma sexta: partitio; no Sobre o orador (2.80), às cinco soma-se a propositio. Na Retórica a Herênio (1.4), a sexta parte é denominada divisio.

418 Tal como apresentado em 3.3.
} 
4. No caso da digressão $0^{419}$ (egressio, que mais comumente passa a ser denominada excessus), se ela for externa à causa, ela não pode ser considerada parte da causa; se estiver incluída na causa, é um ornamento ou um auxílio das partes da causa a partir das quais se faz uma digressão. Então, se qualquer coisa que estiver na causa for denominado parte da causa, por que não podemos denominar partes o argumento, a comparação, os lugares comuns, os afetos e os exemplos?

5. Contudo, eu não concordo com aqueles, como Aristóteles ${ }^{420}$, que eliminam a refutação, como se fosse subordinada à comprovação. - porque a comprovação constrói e a refutação destrói. Mas Aristóteles aporta uma novidade: depois do proêmio, deve seguir-se a proposição, e não a narração. $\mathrm{Na}$ verdade, ele fez isso porque entende a proposição como gênero e a narração como sua espécie, e acredita que esta nem sempre é necessária, enquanto que a primeira é sempre indispensável em toda parte.

6. Mas destas cinco partes do discurso, que estabeleci, se algo há de ser pronunciado primeiro, não por isso há de ser considerado primeiro, é conveniente, porém, analisar prioritariamente qual é o gênero da causa, o que é investigado, o que é favorável, o que é prejudicial ${ }^{421}$; na sequência, o que confirmar e o que refutar e, por fim, como fazer a narração.

7. É que a exposição 422 é uma preparação para as provas e não há como ter utilidade se não se definir de antemão quais devem ser as promessas de comprovação. Por último

\footnotetext{
419 П $\alpha \pi \varepsilon ́ \kappa \beta \alpha \sigma \iota \varsigma=$ egressio (4.3.14). Em Cícero, digressio (Inv. 1.27,97; de Orat. 2.312; Part. 15, etc.). Ou ainda digressus (Quintiliano 2.13.1; 4.2.103), excursus (Quintiliano 4.3.5, 12; 10.5.12) e excessus em Sêneca (Con. 7, pr.1).

420 Rh. 3.1414b 9. De sua parte, Cícero também trata da relação entre confirmação e refutação (de Orat. 2.331; Part. 4, 27, 33; Top. 98).

421 I.e., qual é a quaestio (se simplex ou coniuncta), da qual deriva o status (ver 3.11.1-28 abaixo).

422 Expositio como narratio.
} 
deve-se estudar como cativar o juiz. E sem examinar cuidadosamente as partes de toda a causa, não podemos saber qual estado de ânimo nos será conveniente provocar no juiz: severo ou indulgente, apreensivo ou calmo, irredutível ou influenciável.

8. Nem por isso, eu também não aprovaria aqueles que acham que o proêmio deve ser escrito por último. Pois, da mesma maneira que todo o material deve ser reunido e definido, bem como o lugar mais apropriado para cada parte, antes de começarmos a discursar ou escrever, é preciso começar por aquelas partes que vêm primeiro.

9. Uma vez que ninguém começa a pintar ou esculpir pelos pés, e nenhuma obra de arte é concluída no lugar donde se deve começar. De qualquer forma, o que acontecerá se não tivermos tempo para escrever nosso discurso? Será que tal inversão na ordem habitual não nos faria cair numa armadilha? Portanto, a matéria deve ser examinada na ordem em que ensinei, e escrita na ordem em que discursamos ${ }^{423}$.

${ }^{423}$ Cf 10.7 .30 . 


\section{CAPÍTULO 10}

[Os gêneros de causas]

1. Além disso, toda causa, que apresenta de um lado um acusador e do outro um defensor, baseia-se numa controvérsia, seja sobre um único ou vários pontos. A primeira ocorrência denomina-se causa simples; a segunda, composta ${ }^{424}$. De uma única controvérsia é a causa do furto em si ou do adultério em si. De muitas controvérsias, pode ser de mesmo gênero, como a extorsão de dinheiro, ou de gêneros variados, por exemplo, quando alguém é simultaneamente acusado de sacrilégio e homicídio. Isto já não ocorre nos processos públicos porque atualmente o pretor distribui os casos de acordo com sua lei específica ${ }^{425}$, mas ainda é frequente nas audiências com o Imperador ou no Senado ${ }^{426}$, e assim era nos processos populares. Inclusive, em julgamentos privados, é frequente haver um único juiz decidindo de acordo com muitas e diferentes fórmulas ${ }^{427}$.

\footnotetext{
${ }^{424}$ Esta classificação segue o critério de número de status, um para simples (3.6.91: in causis simplicibus singulos status esse causarum), ou mais de um para composta (3.6.94: in coniunctis uero posse duo et tres inueniri).

${ }^{425}$ Referência ao sistema jurídico-criminal romano, onde tribunais especializados, com pretores que eram nomeados para conduzir julgamentos de violação de uma lei específica (certa lege).

426 Menções a processos criminais debatidos no senado podem ser encontradas, por exemplo, em Tácito (Ann. 3.10-19) ou Plínio (Ep. 2.11; 3.9; 4.9). A criação de tribunais consular-senatoriais datam da época de Augusto, os imperadores determinavam que senadores e cônsules se ocupassem de assuntos penais, fazendo distinções de acordo com a natureza do delito e a qualificação das pessoas. Além disso, havia também uma lista anual de 900 nomes, da qual se compunha um júri, por sorteio, tanto para processo criminais como civis, encaminhada ao pretor urbano (Cf. Cícero, Cluen. 121), esta lista estava formada proporcionalmente de senadores, cavaleiros e tribuni aerarii, conforme a lex Aurelia iudiciaria de 70 a.C. (Cousin , n. compl. p.277).

427 Unus iudex não se refere a um magistrado, mas a um jurado particular escolhido livremente por ambas as partes e autorizado pelo magistrado, cujos poderes cessavam após o julgamento da causa para a qual foi destinado. Formula pode ter dois sentidos: 1. um formulário de prescrições de condições a uma determinado procedimento, que pode ser entendido como um regulamento (p.e., Liv. 27.10.2: milites ex formula parati, "soldados preparados conforme o texto acordado"; 38.9.10: urbem formulae sui iuris faciunt, "submeteriam a cidade sob suas leis"). 2. um escrito apresentado pelo pretor às partes, contendo 0 nome do juiz, os nomes dos defensores, a indicação da coisa reclamada e outras informações referentes ao processo (Cf. Quintiliano 3.6.69). (apud Cousin, trad, n.compl., p.277).
} 
2. Não há nenhum outro tipo de causa além desses ${ }^{428}$, mesmo quando somente uma única pessoa abre um processo contra duas (reclamando uma mesma coisa e pelos mesmos motivos), ou duas pessoas demandam uma única, ou um grupo de pessoas a outro grupo (o que acontece às vezes em disputas de herança, como sabemos) porque, embora possa haver muitas pessoas, a causa, no entanto, é uma só ${ }^{429}$, a não ser que a situação das pessoas faça variar as questões 430 .

3. Diferente desses é o terceiro tipo, denominado comparativo ${ }^{431}$. Com frequência o tratamento dele aparece num determinado ponto da causa, como, por exemplo, perante os centúnviros ${ }^{432}$, quando (depois de outras questões) indaga-se qual dos dois demandantes merece mais a herança. Mas é raro que apenas por essa razão casos

\footnotetext{
${ }^{428}$ Quintiliano rejeita a divisão de alguns autores (não mencionados) que incluiria ainda um tipo de causa de mútua acusação e o gênero comparativo como um quarto tipo. Ele defende que o gênero de causa é o mesmo independente do número de litigantes de cada lado: eandem rem atque ex eadem causa. Mas em 3.6.94, Quintiliano mostra que o genus causa depende do número de status envolvido. Uma causa é complexa se um mesmo status se aplica a duas acusações (ut si quis duo crimina uel omnia negat) ou se envolve mais de um tipo de status (ut si quis aliud se non fecisse, aliud recte fecisse defendat), neste dois casos rem torna-se múltipla.
}

${ }^{429}$ Neste ponto Quintiliano parece contradizer-se com a classificação apresentada em 3.6.95 para causa complexa: quando várias reivindicações têm o mesmo objeto ou o mesmo status. É possível que o autor estivesse considerando que várias acusações, diferentes e específicas, estivessem incluídas numa mesma origem legal.

${ }^{430}$ Em 3.6.96-103 este caso é discutido em detalhes, quando existe a reivindicação de um filho legítimo, um amigo citado no testamento e um filho natural.

431 Embora fale em um tertium genus, Quintiliano considera este tipo inserido na "causa complexa". Neste caso, duas pessoas demandam a mesma coisa (um único status), mas por motivos distintos e o tribunal deve comparar os motivos e decidir entre eles. Trata-se de mesma res, mas a conditio personarum é diferente.

432 Colégio de juízes, entre 105 (séc III a.C.) e 180 jurados (divididos em 4 consilia, no período da República), que tratava de processos que envolviam heranças e disputas civis mais importantes. Na época de Quintiliano era considerado o campo com mais prestígio na advocacia. (Tácito. Dial. 38; Plínio, Ep. $4.24,6.33)$. 
assim sejam levados ao fórum, como nos processos de adivinhação ${ }^{433}$, que são constituídos para saber quem atuará como acusador, e algumas vezes com delatores, para definir qual dos dois merecerá a recompensa.

4. Alguns acrescentaram a esta lista a mútua acusação434 (denominada, em grego,

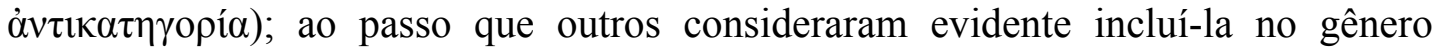
comparativo. Comparável a este gênero é a situação, muito frequente, de acusações recíprocas, mas de crimes diferentes. Se isto, por sua característica, deve ser

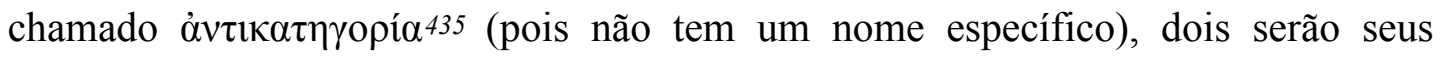
gêneros: um em que os litigantes se acusam mutuamente de um mesmo crime; outro em que cada parte faz uma acusação diferente. A condição é a mesma nos casos de demandas ${ }^{436}$.

\footnotetext{
433 Quando, para uma mesma causa, havia mais de um acusador: os que almejavam ser escolhidos para fazer a acusação apresentavam um discurso denominado divinatio, apresentando suas motivações, intenções e capacidades para convencer o júri a indicá-los para tal causa. Divinatio, portanto, trata-se um processo preliminar que poderia ser entendido como examinação ou inspeção. Um escolasta de época imperial oferece três explicações possíveis para esse denominação: Divinatio dicitur haec oratio, quia non de facto quaeritur hic coniectura, sed de futuro, quae est divinatio uter debeat accusare. Alii ideo putant divinationem dici, quod iniurati iudices in hac causa sedeant et, quod velint, praesentire de utroque possint; alii, quod res agatur sine testibus et sine tabulis, et his remotis argumenta sola sequantur iudices et quasi divinent. "Este discurso chama-se 'adivinhação' porque não se investiga por conjectura o que aconteceu, mas o que acontecerá, que é a adivinhação de qual dos dois deve acusar. Outros consideram que tem esse nome porque os jurados tomam parte na causa sem prestar juramento e podem pressentir o que quiserem sobre ambos; outros, porque o caso é apresentado sem testemunhas e sem documentos, e, deixando estes de lado, os jurados apenas acompanham os argumentos e, por assim dizer, adivinham" (trad. Adriano Scatolin). Um clássico exemplo disto está no discurso ciceroniano Contra Quinto Cecílio, discurso preliminar do processo contra Verres, quando é preciso definir qual dentre muitos acusadores deve apresentar a acusação e Cícero discursa para que não seja admitido Quinto Cecílio Nigro como acusador.
}

${ }^{434}$ Accusatio mutua poderia ser um caso especial da $\mu \varepsilon \tau \dot{\sigma} \sigma \tau \alpha \sigma \iota \varsigma$ de Hermágoras (ver 3.6.56-61).

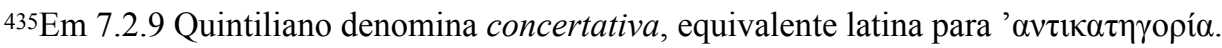

$436 \mathrm{O}$ termo petitio em direito privado designa, no geral, uma reclamação. Em nota ad locum, Jean Cousin (p.218) esclarece que uma "petição" é uma ação do direito civil que envolve um direito de propriedade. 
5. Uma vez que estiver claro qual é o gênero da causa, devemos analisar se é possível negar o fato relatado, se ele é defensável, se é possível dar-lhe outro nome, ou se é preciso excluí-lo deste gênero de processo ${ }^{437}$. Daí vêm os seus status.

437 negaturne factum: coniectura; an defendatur: qualitas; an alio nomine appellatur: definitio; an a genere actionis repellatur: translatio. (Cf. 3.6.68-69). 


\section{CAPÍTULO 11}

[O que é questão, motivo, ponto a julgar e ponto central e em que medida são necessários]

1. Resolvido isso, devemos em seguida, de acordo com Hermágoras, examinar o que é a questão, o motivo, o ponto a julgar e o ponto central (ou, como outros dizem, o fundamento). Em sentido amplo entende-se questão como todo assunto sobre o qual se pode discutir com credibilidade segundo duas ou mais opiniões.

2. Na matéria judicial, porém, a questão pode ser vista de duas formas: ou dizemos que uma controvérsia apresenta muitas questões, incluindo até mesmo todas as questões menores, ou definimos a questão mais importante sobre a qual a causa versa. É desta que falo agora, é com ela que se origina o status: aconteceu? o que aconteceu? aconteceu dentro da lei?

3. Hermágoras, Apolodoro e inúmeros outros escritores chamam-nas "questões", no sentido próprio do termo. Teodoro, como mencionado, classifica-as como "pontos gerais"438, e as de menor importância ou as que dependem das gerais, como "pontos específicos". É consenso que uma questão dá origem a outra questão e que uma espécie se divide em outras.

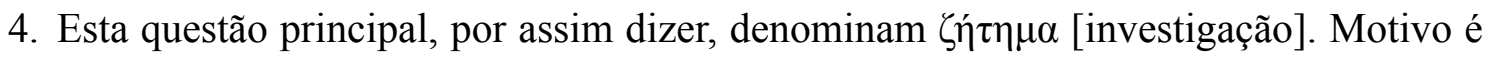
aquilo que permite defender o que sabidamente aconteceu. E por que não usaríamos o mesmo exemplo utilizado por quase todos autores? "Orestes matou sua mãe”. Isto é sabido. "Ele alega que o fez legitimamente". O status será de qualidade; a questão, "se o fez com legitimidade"; o motivo será que Clitemnestra matou seu marido, pai

${ }^{438}$ Ver 2.13.6; 3.6.2; 3.11.27. 


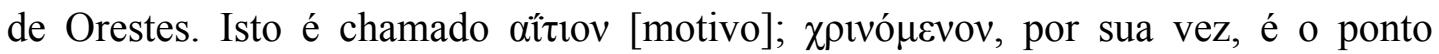
central: "é certo que uma mãe, ainda que criminosa, seja morta pelo seu filho?"

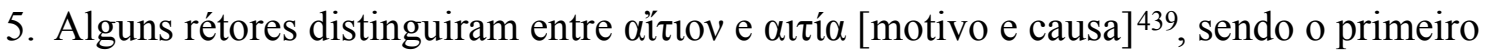
o motivo para constituir um processo — neste caso, o assassinato de Clitemnestra - ; o segundo, a razão pela qual se defende o que aconteceu - aqui, o assassinato de Agamêmnon. Mas existe tamanha divergência acerca da nomenclatura que alguns

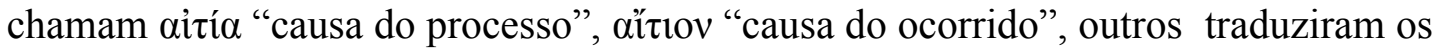
mesmos termos inversamente. Alguns latinos os denominaram respectivamente ponto inicial e motivo ${ }^{440}$, outros empregaram o mesmo nome para ambos.

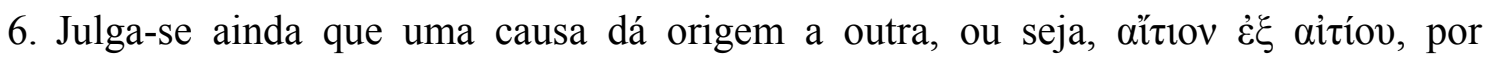
exemplo: Clitemnestra matou Agamemnon porque ele sacrificara a filha deles e levara para casa uma escrava como amante ${ }^{441}$. Os mesmos autores consideram que pode haver, para uma única questão, muitos motivos. Por exemplo, se Orestes apresentasse uma segunda justificativa para assassinar a mãe: ter sido movido por um oráculo $^{442}$. Há tantos pontos a julgar quanto o número de causas; o ponto a julgar será: "Orestes devia ter obedecido aos oráculos?"

7. No entanto, na minha opinião, uma única causa pode apresentar muitas questões e muitos pontos a serem julgados. Por exemplo, o caso em que um homem mata sua mulher, flagrada em adultério, e mais tarde, no fórum, mata o adúltero, que então

439 Enquanto aĩtıov é supostamente o termo empregado por Hermágoras como "base da acusação inicial"

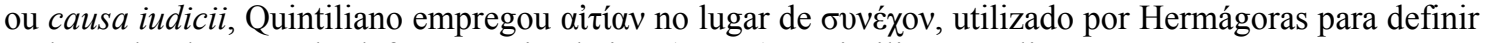

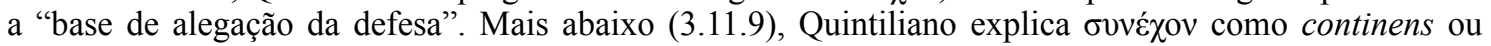
firmamentum.

440 Em 3.11.4, Quintiliano emprega os mesmos termos: causa iudicii e ratio. A seguir (3.11.20), porém, ele agrupa os dois em continens.

${ }^{441}$ No processo de Orestes, a aît tov seria Clitemnestra ter matado Agamémnon; mas em favor dela - que caracterizaria a aïtıv $\grave{\varepsilon} \xi$ aiıíov - poderia ser alegada a morte de Ifigênia por Agamémnon e depois disso o fato de ele ter levado para casa Cassandra como sua amante.

442 Cf. Sófocles, El. 35-37; Eurípedes, Or. 31. 
havia conseguido escapar ${ }^{443}$. A justificativa é uma só: "era um adúltero". As questões e os pontos a julgar são: “era lícito matá-lo naquele momento e naquele lugar?”444

8. Mas tal como, mesmo havendo muitas questões e cada uma com seu status, há um único status da causa, ao qual tudo está relacionado, da mesma forma há um ponto principal específico a julgar, sobre o qual se decide ${ }^{445}$.

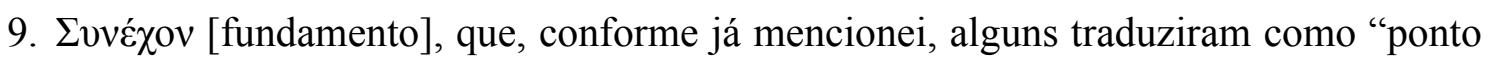
central" outros como "fundamento", Cícero definiu como "o argumento mais eficaz da defesa e o mais adequado para a sentença do juiz" 446 . Alguns rétores o consideram o argumento depois do qual nada mais pode ser questionado, outros o mais eficaz para a decisão do juiz.

10.A motivação do ato não ocorre em todas as controvérsias; pois qual seria a motivação para agir quando o fato é negado? Mas quando a motivação é referida, eles dizem que o ponto essencial do julgamento não está no mesmo lugar que a questão. Isso também foi dito por Cícero na sua Retórica e nas Partições ${ }^{447}$.

11.Na conjectura a questão deriva do seguinte: "aconteceu", "não aconteceu", “aconteceu?”. O ponto essencial a julgar, portanto, encontra-se no mesmo lugar da questão, porque a primeira questão e a última discussão ${ }^{448}$ tratam do mesmo tema.

\footnotetext{
443 Ver 5.10.39 para um caso semelhante.

${ }^{444}$ Segundo uma antiga lei romana, ao marido era permitido matar ambos adúlteros quando surpreendido no ato, mas era preciso matar os dois juntos (cf. Gel. 10.23.5; Quint., Inst. 3.6.17; 5.10.39, 88, 104; 71.1). Mas a Lex Iulia de adulteriis (17 a.C) autorizava apenas que o homem fosse morto e desde que fosse infames ou inhonestus.

445 I.e., maxime propria quaestionis ou causae (3.11.16). Cícero, de Orat. 2.114: constituto...quae sit propria quaestionis et iudicii).

446 Inv. $1.14,19$.

447 Inv. 1.19; Part. 104.

448 I.e., a iudicatio. Nas Partições oratórias, Cícero emprega a expressão extrema disceptatio (104: Itaque in his causis eadem et prima quaestio et disceptatio extrema) para fazer distinção entre a indicativo e a diffusa quaestio que surge a partir da prima adversariorum contentio.
} 
No caso da qualidade temos o seguinte: "Orestes matou a mãe", "legitimamente", "sem legitimidade"; a questão é se ele matou legitimamente, mas ainda não se trata do ponto essencial. Quando então apareceria? "Ela tinha matado meu pai". "Mas não é por isso que deverias ter matado tua mãe.” Deveria matá-la? Este é o ponto essencial a julgar.

12.Quanto ao fundamento citarei as palavras do próprio Cícero: "Se quisesse, Orestes alegaria que a atitude da sua mãe com relação a seu pai, a ele mesmo, a suas irmãs, ao reino, à reputação da linhagem e da família, foi tal que cabia sobretudo a seus filhos o dever de aplicar-lhe os castigos"449.

13.Outros autores valem-se também dos seguintes exemplos: "quem dilapidar os bens paternos não deve tomar parte na assembleia popular" ${ }^{450}$. "Mas este homem gastou seu patrimônio particular em obras públicas”. A questão é: “cabe impedir todo aquele que dilapidou [seu patrimônio]?”. O ponto essencial a julgar: “cabe impedir quem agiu assim?"

14.Ou então na causa do soldado Arruntio ${ }^{451}$, que matou o tribuno Lúsio quando este tentou violentá-lo: a questão é "ele o fez legitimamente?"; o motivo é "o tribuno

449 Inv. 1.19.

$450 \mathrm{Cf}$. ad Her. 1.20: Lex vetat eum qui de pecuniis repetundis damnatus sit in contionem habere. Cf. Quintiliano, Inst.7.6.3: ex meretrice natus ne conionetur. A lei estabelece que pessoas consideradas infames perdiam o privilégio de alguns cidadãos, como representar alguém num tribunal ou falar diante de uma assembleia.

451 Em 104 a.C. um soldado matou o tribuno Lúsio, sobrinho do general Mário. Posteriormente o caso foi explicado pelo próprio Mário: o tribuno teria tentado tirar vantagens sexuais do soldado. Este episódio foi mencionado por vários autores: Cícero Inv. 2.124; Mil. 9; Valério Máximo 6.12; [Quintiliano] Decl. 2; Calpúrnio Flacco 3. O nome do soldado é diferente entre os autores. Quintilano o chama da Arrúntio, Valério Máximo diz que seu nome é C.Plótio, em Plutarco (Mar. 14) ele é Trebônio. Neste caso, Jean Cousin (nota complementar p. 281) menciona a relatio criminis, apresentada por Cícero em Inv. 2.124: ut in eo milite, qui, cum communis lex omnium hominem occidere uetaret, tribunum militum, qui uim sibi afferre conaretur, occidit. Há ocorrência de duas questões: matar um homem ainda não condenado (questão geral), um soldado matar um tribuno (questão particular). 
tentou violentá-lo"; o ponto essencial a julgar é a licitude de alguém ser morto sem estar condenado, de um tribuno ser morto por um soldado.

15.Alguns autores até mesmo consideraram haver, num caso, um status da questão, e no outro, um status do ponto essencial a julgar. A questão de qualidade seria: "Milão matou Clódio legitimamente?”; um ponto essencial de conjectura: “Clódio armou uma emboscada?".

16.Eles estabelecem também o seguinte: muitas vezes a causa é desviada a um tema que não é o específico da questão e é sobre ele que se deve julgar. Discordo totalmente deles: é preciso que uma questão como: "cabe proibir de participar da assembleia popular todo aquele que dilapidou a herança paterna?" apresente seu próprio ponto essencial. Portanto não haverá de um lado uma questão e de outro um ponto essencial, mas várias questões e vários pontos essenciais a julgar.

17.Ora, na causa de Milão não está a própria conjectura relacionada com a qualidade? Se Clódio armou uma emboscada, consequentemente foi morto com legitimidade. Mas quando a causa é desviada a algum outro tema distancia-se da questão inicial e a questão reside no ponto a julgar.

18.Com relação a este tema, até mesmo Cícero se contradiz um pouco. Na sua Retórica, como disse acima, ele seguiu Hermágoras ${ }^{452}$; nos Topicos $^{453}$ ele sustenta que крıvó $\mu \varepsilon v o v$ é a disputa produzida pelo status e, fazendo uma alusão a Trebácio (que era jurisconsulto), o define como "a matéria de que trata", e os dispositivos onde se inclui isso são: “os pontos essenciais do processo, como sendo os fundamentos da defesa, sem os quais não há defesa”.

452 Ver 3.11.1-28.

453 Inv. 1.18-19; Top. 95; Part. 103. 
19.Mas nas Partições oratórias ele define "fundamento" aquilo que se objeta contra a defesa, uma vez que o "ponto central", por ser o que vem em primeiro lugar no julgamento, é apresentado pela acusação; o "motivo", pelo réu. A discussão sobre os pontos a julgar surge a partir da questão derivada do motivo e do fundamento. Mais corretos e mais sucintos foram os que disseram haver três elementos envolvidos num processo: o status, o ponto central e o ponto a julgar; e que o ponto central454 é aquilo sem o qual não pode haver um processo ${ }^{455}$.

20.Com isso parece-me que eles abarcaram as duas motivações: para Orestes matar sua mãe e para Clitemnestra matar Agamêmnon. Os mesmos autores pensaram que o ponto a julgar e o status sempre coincidem: efetivamente nenhuma outra abordagem seria conveniente ao método deles.

21.Mas deixemos este detalhismo afetado em torno da nomenclatura a seus esforços pretensiosos, apresentamos somente para não dar a impressão de ter investigado pouco cuidadosamente a tarefa que assumimos. No entanto, para um mestre que quer trabalhar de forma mais simples, não é necessário esmiuçar em questiúnculas tão insignificantes o seu método de ensino.

22. Muitos padeceram deste mesmo defeito, sobretudo Hermágoras, homem de resto meticuloso e admirável em muitos aspectos — tinha um cuidado tão obsessivo que até mesmo essa crítica não seria indigna de algum elogio.

23.Um método mais enxuto e, por isso mesmo, muito mais claro não irá cansar o aprendiz com rodeios nem enfraquecer o corpo do discurso dividindo-o em

\footnotetext{
454 Continens apresenta significado diferente daquele referido em 3.11.19. Aqui o termo abarca duas ideias: initium (quod Orestes matrem occiderit) e ratio (quod...Clytaemestra Agamemnonem occiderit), como aparece em 3.11.5. Cícero, nas Partições (103) emprega este termo para designar a súplica de justificação da defesa e a réplica da acusação.

${ }^{455}$ Cf. ad Her. 1.26; Cícero, Inv. 1.18, de Orat. 2.132, Part. 103.
} 
ramificações insignificantes. Aquele que consegue perceber o que está em controvérsia, o que a parte contrária quer alcançar e com quais recursos, bem como a nossa parte — que deve ser considerado antes de mais nada —, não poderá ignorar nenhum dos pontos mencionados.

24.Não existe praticamente ninguém, desde que não se trate de uma pessoa estúpida e completamente alheia à prática da oratória, que não saiba o que ocasiona um litígio (definido por aqueles autores como causa ou ponto central), qual é a questão entre os litigantes, e sobre o que cabe julgar. Todos isso é a mesma coisa: não apenas a questão está relacionada àquilo que entra em controvérsia, mas também julga-se aquilo de que trata a questão.

25.Mas nós não prestamos sempre atenção a coisas desse tipo; seja pelo desejo de receber elogios a qualquer preço ou pelo simples prazer de discursar, divagamos. É que o material externo à causa é sempre mais fértil, pois na controvérsia há pouca matéria e fora dela encontra-se todo tipo de tema. No primeiro caso falamos sobre o que nos foi passado, no segundo sobre o que quisermos.

26.Ensinar a encontrar a questão, o ponto central, o ponto a julgar não é tão importante (pois isso é realmente fácil) quanto recomendar manter os olhos bem abertos, ou pelo menos ter muita segurança ao olhar para trás quando fizermos uma digressão, para que na sede de aplausos não deixemos cair as armas.

27.A Escola de Teodoro, como disse $\mathrm{e}^{456}$, atrela tudo isso aos pontos capitais. Depreendem-se do termo vários sentidos: primeiro, é a questão principal, tal qual o status; segundo, tudo o mais que se relaciona à questão principal; terceiro, a proposição com a confirmação, como quando dizemos "é o ponto essencial do 


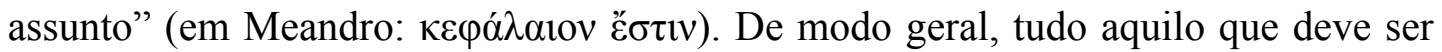
comprovado será um ponto capital, mas de maior ou menor importância.

28.Depois de expor o que apresentaram os escritores de manuais, de maneira mais prolixa do que era necessário, e também, anteriormente, as partes das causas judiciais, o livro seguinte começará falando sobre a primeira delas, isto é, o exórdio. 


\section{FABII QUINTILIANI INSTITUTIO ORATORIA}

\section{LIBER TERTIUS}

[De scriptoribus artis rhetoricae]

1. Quoniam in libro secundo quaesitum est quid esset rhetorice et quis finis eius, artem quoque esse eam et utilem et uirtutem, ut uires nostrae tulerunt, ostendimus, materiamque ei res omnes de quibus dicere oporteret subiecimus: iam hinc unde coeperit, quibus constet, quo quaeque in ea modo inuenienda atque tractanda sint exequar: intra quem modum plerique scriptores artium constiterunt, adeo ut Apollodorus contentus solis iudicialibus fuerit.

2. Nec sum ignarus hoc a me praecipue quod hic liber inchoat opus studiosos eius desiderasse, ut inquisitione opinionum, quae diuersissimae fuerunt, longe difficillimum, ita nescio an 'minimae legentibus futurum uoluptati, quippe quod prope nudam praeceptorum traditionem desideret. 3. In ceteris enim admiscere temptauimus aliquid nitoris, non iactandi ingenii gratia (namque in id eligi materia poterat uberior), sed ut hoc ipso adliceremus magis iuuentutem ad cognitionem eorum quae necessaria studiis arbitrabamur, si ducti iucunditate aliqua lectionis libentius discerent ea quorum ne ieiuna atque arida traditio auerteret animos et aures 
praesertim tam delicatas raderet uerebamur. 4. Qua ratione se Lucretius dicit praecepta philosophiae carmine esse complexum; namque hac, ut est notum, similitudine utitur:

"ac ueluti pueris absinthia taetra medentes

cum dare conantur, prius oras pocula circum adspirant mellis dulci flauoque liquore"

et quae secuntur. 5. Sed nos ueremur ne parum hic liber mellis et absinthii multum habere uideatur, sitque salubrior studiis quam dulcior. Quin etiam hoc timeo, ne ex eo minorem gratiam ineat, quod pleraque non inuenta per me sed ab allis tradita continebit, habeat etiam quosdam qui contra sentiant et aduersentur, propterea quod plurimi auctores, quamuis eodem tenderent, diuersas tamen uias munierunt atque in suam quisque induxit sequentes. 6. Illi autem probant qualecumque ingressi sunt iter, nec facile inculcatas pueris persuasiones mutaueris, quia nemo non didicisse mauult quam discere. 7. Est autem, ut procedente libro patebit, infinita dissensio auctorum, primo ad ea quae rudia atque inperfecta adhuc erant adicientibus quod inuenissent scriptoribus, mox, ut aliquid sui uiderentur adferre, etiam recta mutantibus.

8. Nam primus post eos quos poetae tradiderunt mouisse aliqua circa rhetoricen Empedocles dicitur. Artium autem scriptores antiquissimi Corax et Tisias Siculi, quos insecutus est uir eiusdem insulae Gorgias Leontinus, 
Empedoclis, ut traditur, discipulus. 9. Is beneficio longissimae aetatis (nam centum et nouem uixit annos) cum multis simul floruit, ideoque et illorum de quibus supra dixi fuit aemulus et ultra Socraten usque durauit. 10. Thrasymachus Calchedonius cum hoc et Prodicus Cius et Abderites Protagoras, a quo decem milibus denariorum didicisse artem quam edidit Euathlus dicitur, et Hippias Elius, et, quem Palameden Plato appellat, Alcidamas Elaites. 11. Antiphon quoque, et orationem primus omnium scripsit et nihilo minus artem et ipse composuit et pro se dixisse optime est creditus; etiam Polycrates, a quo scriptam in Socraten diximus orationem, et Theodorus Byzantius, ex iis et ipse quos Plato appellat logodaedalos. 12. Horum primi communis locos tractasse dicuntur Protagoras, Gorgias, adfectus Prodicus, Hippias et idem Protagoras et Thrasymachus. Cicero in Bruto negat ante Periclea scriptum quicquam quod ornatum oratorium habeat: eius aliqua ferri. Equidem non reperio quicquam tanta eloquentiae fama dignum, ideoque minus miror esse qui nihil ab eo scriptum putent, haec autem quae feruntur ab aliis esse composita.

13. His successere multi, sed clarissimus Gorgiae auditor Isocrates, (quamquam de praeceptore eius inter auctores non conuenit: nos tamen Aristoteli credimus). 14. Hinc uelut diuersae secari coeperunt uiae. Nam et Isocratis praestantissimi discipuli fuerunt in omni studiorum genere, eoque iam seniore (octauum enim et nonagesimum impleuit annum) postmeridianis scholis Aristoteles praecipere artem oratoriam coepit, noto 
quidem illo, ut traditur, uersu ex Philocteta frequenter usus: 'turpe esse tacere et Isocraten pati dicere.' Ars est utriusque, sed pluribus eam libris Aristoteles complexus est. Eodem tempore Theodectes fuit, de cuius opere supra dictum est. 15. Theophrastus quoque, Aristotelis discipulus, de rhetorice diligenter scripsit, atque hinc uel studiosius philosophi quam rhetores praecipueque Stoicorum ac Peripateticorum principes. 16. Fecit deinde uelut propriam Hermagoras uiam, quam plurimi sunt secuti. Cui maxime par atque aemulus uidetur Athenaeus fuisse.

Multa post Apollonius Molon, multa Areus, multa Caecilius et Halicarnasseus Dionysius. 17. Praecipue tamen in se conuerterunt studia Apollodorus Pergamenus, qui praeceptor Apolloniae Caesaris Augusti fuit, et Theodorus Gadareus, qui se dici maluit Rhodium: quem studiose audisse cum in eam insulam secessisset dicitur Tiberius Caesar. 18. Hi diuersas opiniones tradiderunt appellatique inde Apollodorei ac Theodorei ad morem certas in philosophia sectas sequendi. Sed Apollodori praecepta magis ex discipulis cognoscas, quorum diligentissimus in tradendo fuit Latine C. ualgius, Graece Atticus. Nam ipsius sola uidetur ars edita ad Matium, quia ceteras missa ad Domitium epistula non agnoscit. Plura scripsit Theodorus, cuius auditorem Hermagoran sunt qui uiderint.

19. Romanorum primus, quantum ego quidem sciam, condidit aliqua in hanc materiam M. Cato ille censorius, post M. Antonius inchoauit: nam hoc solum opus eius atque id ipsum inperfectum manet. Secuti minus celebres, 
quorum memoriam, si quo loco res poscet, non omittam. 20. Praecipuum uero lumen sicut eloquentiae, ita praeceptis quoque eius dedit unicum apud nos specimen orandi docendique oratorias artes M. Tullius, post quem tacere modestissimum foret, nisi et rhetoricos suos ipse adulescenti sibi elapsos diceret, et in oratoriis haec minora, quae plerumque desiderantur, sciens omisisset. 21. Scripsit de eadem materia non pauca Cornificius, aliqua Stertinius, non nihil pater Gallio, accuratius uero priores Gallione Celsus et Laenas et aetatis nostrae uerginius Plinius Tutilius. Sunt et hodie clari eiusdem operis auctores, qui si omnia complexi forent, consuluissent labori meo. Sed parco nominibus uiuentium; ueniet eorum laudi suum tempus: ad posteros enim uirtus durabit, non perueniet inuidia.

22. Non tamen post tot ac tantos auctores pigebit meam quibusdam locis posuisse sententiam. Neque enim me cuiusquam sectae uelut quadam superstitione inbutus addixi, et electuris quae uolent facienda copia fuit, sicut ipse plurium in unum confero inuenta, ubicumque ingenio non erit locus curae testimonium meruisse contentus.

[Quod initium rhetorices]

1. Nec diu nos moretur quaestio quae rhetorices origo sit. Nam cui dubium est quin sermonem ab ipsa rerum natura geniti protinus homines 
acceperint (quod certe principium est eius rei), huic studium et incrementum dederit utilitas, summam ratio et exercitatio? 2. Nec uideo quare curam dicendi putent quidam inde coepisse, quod ii qui in discrimen aliquod uocabantur accuratius loqui defendendi sui gratia instituerint. Haec enim ut honestior causa, ita non utique prior est, cum praesertim accusatio praecedat defensionem, nisi quis dicet etiam gladium fabricatum ab eo prius qui ferrum in tutelam sui quam qui in perniciem alterius compararit. 3. Initium ergo dicendi dedit natura, initium artis obseruatio. Homines enim sicut in medicina, cum uiderent alia salubria, alia insalubria, ex obseruatione eorum effecerunt artem, ita cum in dicendo alia utilia, alia inutilia deprenderent, notarunt ea ad imitandum uitandumque, et quaedam secundum rationem eorum adiecerunt ipsi quoque: haec confirmata sunt usu. Tum quae sciebat quisque docuit. 4. Cicero quidem initium orandi conditoribus urbium ac legum latoribus dedit, in quibus fuisse uim dicendi necesse est: cur tamen hanc primam originem putet non uideo, cum sint adhuc quaedam uagae et sine urbibus ac sine legibus gentes, et tamen qui sunt in iis nati et legationibus fungantur et accusent aliqua atque defendant et denique alium alio melius loqui credant. 
1. Omnis autem orandi ratio, ut plurimi maximique auctores tradiderunt, quinque partibus constat: inuentione dispositione elocutione memoria pronuntiatione siue actione (utroque enim modo dicitur). Omnis uero sermo, quo quidem uoluntas aliqua enuntiatur, habeat necesse est rem et uerba. 2. Ac si est breuis et una conclusione finitus, nihil fortasse ultra desideret: at oratio longior plura exigit. Non enim tantum refert quid et quo modo dicamus, sed etiam quo loco: opus ergo est et dispositione. Sed neque omnia quae res postulat dicere neque suo quaeque loco poterimus nisi adiuuante memoria, quapropter ea quoque pars quarta erit. 3. Verum haec cuncta corrumpit ac propemodum perdit indecora uel uoce uel gestu pronuntiatio: huic quoque igitur tribuendus est necessario quintus locus.

4. Nec audiendi quidam, quorum est Albucius, qui tris modo primas esse partis uolunt, quoniam memoria atque actio natura non arte contingant: quarum nos praecepta suo loco dabimus; licet Thrasymachus quoque idem de actione crediderit. 5. His adiecerunt quidam sextam partem, ita ut inuentioni iudicium subnecterent, quia primum esset inuenire, deinde iudicare. Ego porro ne inuenisse quidem credo eum qui non iudicauit; neque enim contraria communia stulta inuenisse dicitur quisquam, sed non uitasse. 6. Et Cicero quidem in rhetoricis iudicium subiecit inuentioni: mihi autem adeo tribus primis partibus uidetur esse permixtum (nam neque dispositio sine eo neque elocutio fuerit) ut pronuntiationem quoque uel plurimum ex eo mutuari putem. 7. Quod hoc audacius dixerim quod in 
Partitionibus Oratoriis ad easdem de quibus supra dictum est quinque peruenit partes. Nam cum dupliciter primum diuisisset in inuentionem atque elocutionem, res ac dispositionem inuentioni, uerba et pronuntiationem elocutioni dedit, quintamque constituit communem ac uelut custodem omnium memoriam; idem in Oratore quinque rebus constare eloquentiam dicit: in quibus postea scriptis certior eius sententia est. 8. Non minus mihi cupidi nouitatis alicuius uidentur fuisse qui adiecerunt ordinem cum dispositionem dixissent, quasi aliud sit dispositio quam rerum ordine quam optimo conlocatio. Dion inuentionem modo et dispositionem tradidit, sed utramque duplicem rerum et uerborum, ut sit elocutio inuentionis, pronuntiatio dispositionis, his quinta pars memoriae accedat. Theodorei fere inuentionem duplicem rerum atque elocutionis, deinde tris ceteras partes. 9. Hermagoras iudicium partitionem ordinem quaeque sunt elocutionis subicit oeconomiae, quae Graece appellata ex cura rerum domesticarum et hic per abusionem posita nomine Latino caret.

10. Est et circa hoc quaestio, quod memoriam in ordine partium quidam inuentioni, quidam dispositioni subiunxerunt: nobis quartus eius locus maxime placet. Non enim tantum inuenta tenere ut disponamus, nec disposita ut eloquamur, sed etiam uerbis formata memoriae mandare debemus; hac enim omnia quaecumque in orationem conlata sunt continentur. 
11. Fuerunt etiam in hac opinione non pauci, ut has non rhetorices partis esse existimarent, sed opera oratoris; eius enim esse inuenire disponere eloqui et cetera. Quod si accipimus, nihil arti relinquemus. 12. Nam bene dicere est oratoris, rhetorice tamen erit bene dicendi scientia: uel ut alli putant, artificis est persuadere, uis autem persuadendi artis. Ita inuenire quidem et disponere oratoris, inuentio autem et dispositio rhetorices propria uideri potest.

13. In eo plures dissenserunt, utrumne hae partes essent rhetorices an

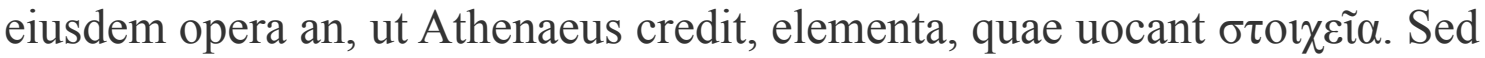
neque elementa recte quis dixerit: alioqui tantum initia erunt, ut mundi uel umor uel ignis uel materia uel corpora insecabilia; nec operum recte nomen accipient quae non ab aliis perficiuntur sed aliud ipsa perficiunt; partes igitur. 14. Nam cum sit ex his rhetorice, fieri non potest ut, cum totum ex partibus constet, non sint partes totius ex quibus constat. uidentur autem mihi qui haec opera dixerant eo quoque moti, quod in alia rursus diuisione nollent in idem nomen incidere; partes enim rhetorices esse dicebant laudatiuam deliberatiuam iudicialem. Quae si partes sunt, materiae sunt potius quam artis. 15. Namque in his singulis rhetorice tota est, quia et inuentionem et dispositionem et elocutionem et memoriam et pronuntiationem quaecumque earum desiderat. Itaque quidam genera tria rhetorices dicere maluerunt, optime autem ii quos secutus est Cicero, genera causarum. 
[Quae genera causarum]

1. Sed tria an plura sint ambigitur. Nec dubie prope omnes utique summae apud antiquos auctoritatis scriptores Aristotelen secuti, qui nomine tantum alio contionalem pro deliberatiua appellat, hac partitione contenti fuerunt. 2. Verum et tum leuiter est temptatum, cum apud Graecos quosdam tum apud Ciceronem in libris de Oratore, et nunc maximo temporum nostrorum auctore prope inpulsum, ut non modo plura haec genera sed paene innumerabilia uideantur. 3. Nam si laudandi ac uituperandi officium in parte tertia ponimus, in quo genere uersari uidebimur, cum querimur, consolamur, mitigamus, concitamus, terremus, confirmamus, praecipimus, obscure dicta interpretamur, narramus, deprecamur, gratias agimus, gratulamur, obiurgamus, maledicimus, describimus, mandamus, renuntiamus, optamus, opinamur, plurima alia? 4. Vt mihi in illa uetere persuasione permanenti uelut petenda sit uenia quaerendumque quo moti priores rem tam late fusam tam breuiter adstrinxerint.

Quos qui errasse putant, hoc secutos arbitrantur, quod in his fere uersari tum oratores uidebant; 5. nam et laudes ac uituperationes scribebantur, et $\dot{\varepsilon} \pi \imath \alpha \varphi$ íovs dicere erat moris, et plurimum in consiliis ac iudiciis 
insumebatur operae, ut scriptores artium pro solis comprenderint frequentissima. 6. Qui uero defendunt, tria faciunt genera auditorum: unum quod ad delectationem conueniat, alterum quod consilium accipiat, tertium quod de causis iudicet. Mihi cuncta rimanti et talis quaedam ratio succurrit, quod omne orationis officium aut in iudiciis est aut extra iudicia. 7. Eorum de quibus iudicio quaeritur manifestum est genus: ea quae ad iudicem non ueniunt aut praeteritum habent tempus aut futurum: praeterita laudamus aut uituperamus, de futuris deliberamus. 8. Item omnia de quibus dicendum est aut certa sint necesse est aut dubia. Certa ut cuique est animus laudat aut culpat; ex dubiis partim nobis ipsis ad electionem sunt libera: de his deliberatur; partim aliorum sententiae commissa: de his lite contenditur.

9. Anaximenes iudicialem et contionalem generalis partes esse uoluit, septem autem species: hortandi, dehortandi, laudandi, uituperandi,

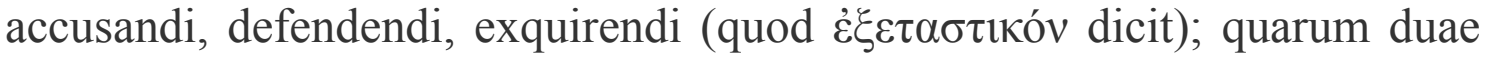
primae deliberatiui, duae sequentes demonstratiui, tres ultimae iudicialis generis sunt partes. 10. Protagoran transeo, qui interrogandi respondendi mandandi precandi (quod $\varepsilon \hat{\chi} \chi \omega \lambda \eta \dot{\eta} \nu$ dixit) partes solas putat. Plato in Sophiste iudiciali et contionali tertiam adiecit $\pi \rho \circ \sigma o \mu \imath \lambda \eta \tau \imath \kappa o ́ v$, quam sane permittamus nobis dicere sermocinatricem; quae a forensi ratione diiungitur et est accommodata priuatis disputationibus, cuius uis eadem profecto est quae dialecticae. 11. Isocrates in omni genere inesse laudem ac uituperationem existimauit. 
12. Nobis et tutissimum est auctores plurimos sequi et ita uidetur ratio dictare. Est igitur, ut dixi, unum genus, quo laus ac uituperatio continetur, sed est appellatum a parte meliore laudatiuum; idem alii demonstratiuum

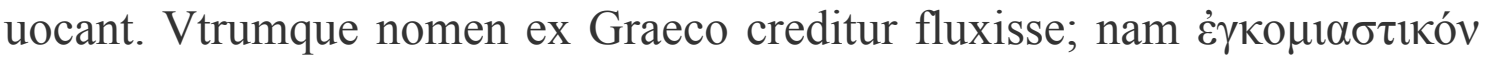

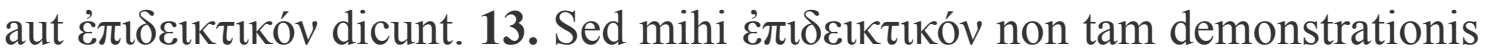
uim habere quam ostentationis uidetur et multum ab illo $\dot{\varepsilon} \gamma \kappa \omega \mu \iota \alpha \sigma \tau \iota \kappa \tilde{\omega}$ differre; nam ut continet laudatiuum in se genus, ita non intra hoc solum

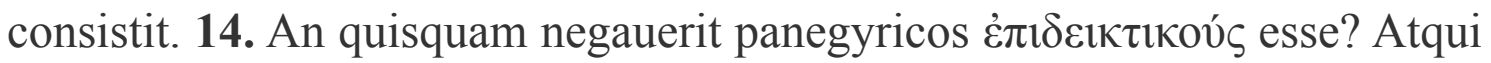
formam suadendi habent et plerumque de utilitatibus Graeciae locuntur: ut causarum quidem genera tria sint, sed ea tum in negotiis, tum in ostentatione posita. Nisi forte non ex Graeco mutantes demonstratiuum uocant, uerum id secuntur, quod laus ac uituperatio quale sit quidque demonstrat. 15. Alterum est deliberatiuum, tertium iudiciale. Ceterae species in haec tria incident genera: nec inuenietur ex his ulla in qua non laudare aut uituperare, suadere aut dissuadere, intendere quid uel depellere debeamus. Illa quoque sunt communia, conciliare narrare docere augere minuere, concitandis componendisue adfectibus animos audientium fingere. 16. $\mathrm{Ne}$ iis quidem accesserim, qui laudatiuam materiam honestorum, deliberatiuam utilium, iudicialem iustorum quaestione contineri putant, celeri magis ac rutunda usi distributione quam uera. Stant enim quodam modo mutuis auxiliis omnia; nam et in laude iustitia 
utilitasque tractatur et in consiliis honestas, et raro iudicialem inueneris causam in cuius non parte aliquid eorum quae supra diximus reperiatur.

[Quibus contineatur omnis ratio dicendi]

1. Omnis autem oratio constat aut ex iis quae significantur aut ex iis quae significant, id est rebus et uerbis. Facultas orandi consummatur natura arte exercitatione, cui partem quartam adiciunt quidam imitationis, quam nos arti subicimus. 2. Tria sunt item quae praestare debeat orator, ut doceat moueat delectet. Haec enim clarior diuisio quam eorum qui totum opus in res et in adfectus partiuntur. Non semper autem omnia in eam quae tractabitur materiam cadent. Erunt enim quaedam remotae ab adfectibus, qui ut non ubique habent locum, ita quocumque inruperunt plurimum ualent. 3. Praestantissimis auctoribus placet alia in rhetorice esse, quae probationem desiderent, alia quae non desiderent, cum quibus ipse consentio. Quidam uero, ut Celsus, de nulla re dicturum oratorem, nisi de qua quaeratur, existimant; cui cum maxima pars scriptorum repugnat, tum etiam ipsa partitio, nisi forte laudare quae constet esse honesta, et uituperare, quae ex confesso sint turpia, non est oratoris officium. 
4. Illud iam omnes fatentur, esse quaestiones aut in scripto aut in non scripto. In scripto sunt de iure, in non scripto de re: illud legale, hoc rationale genus Hermagoras atque eum secuti uocant, id vouıкóv et $\lambda$ oүıкóv. 5. Idem sentiunt qui omnem quaestionem ponunt in rebus et uerbis.

Item conuenit quaestiones esse aut infinitas aut finitas. Infinitae sunt quae remotis personis et temporibus et locis ceterisque similibus in utramque

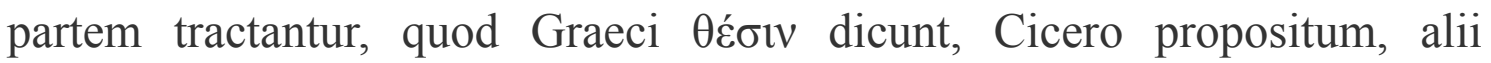
quaestiones uniuersales ciuiles, alii quaestiones philosopho conuenientis; Athenaeus partem causae appellat. 6. Hoc genus Cicero scientia et actione distinguit, ut sit scientiae 'an prouidentia mundus regatur', actionis 'an accedendum ad rem publicam administrandam'. Prius trium generum, 'an sit', 'quid sit', 'quale sit': omnia enim haec ignorari possunt; sequens duorum, 'quo modo adipiscamur', 'quo modo utamur'. 7. Finitae autem sunt ex complexu rerum personarum temporum ceterorumque: hae vं uidetur circa res personasque consistere. 8. Amplior est semper infinita, inde enim finita descendit. Quod ut exemplo pateat, infinita est 'an uxor ducenda', finita 'an Catoni ducenda', ideoque esse suasoria potest. Sed etiam remotae a personis propriis ad aliquid referri solent. Est enim simplex: 'An res publica administranda'; refertur ad aliquid 'an in tyrannide 
administranda'. 9. Sed hic quoque subest uelut latens persona tyrannus; enim geminat quaestionem, subestque et temporis et qualitatis tacita uis; nondum tamen hoc proprie dixeris causam. Hae autem quas infinitas uoco et generales appellantur: quod si est uerum, finitae speciales erunt. In omni autem speciali utique inest generalis, ut quae sit prior. 10. Ac nescio an in causis quoque quidquid in quaestionem uenit qualitatis generale sit. Milo Clodium occidit, iure occidit insidiatorem: nonne hoc quaeritur, an sit ius insidiatorem occidendi? Quid in coniecturis? Non illa generalia: 'An causa sceleris odium, cupiditas', 'An tormentis credendum', 'Testibus an argumentis maior fides habenda'? Nam finitione quidem comprendi nihil non in uniuersum certum erit. 11. Quidam putant etiam eas $\theta \varepsilon \dot{\sigma \varepsilon \varepsilon 1 \varsigma}$ posse aliquando nominari quae personis causisque contineantur, aliter tantummodo positas, ut causa sit cum Orestes accusatur, thesis an Orestes recte sit absolutus, cuius generis est: an Cato recte Marciam Hortensio tradiderit. Hi $\theta \varepsilon \dot{\sigma} \sigma \mathrm{v}$ a causa sic distingunt ut illa sit spectatiuae partis, haec actiuae; illic enim ueritatis tantum gratia disputari, hic negotium agi.

12. Quamquam inutiles quidam oratori putant uniuersales quaestiones, quia nihil prosit quod constet ducendam esse uxorem uel administrandam rem publicam si quis uel aetate uel ualetudine impediatur. Sed non omnibus eius modi quaestionibus sic occurri potest, ut illis: 'sitne uirtus finis', 'regaturne prouidentia mundus'. 13. Quin etiam in iis quae ad personam referuntur, ut non est satis generalem tractasse quaestionem, ita perueniri ad 
speciem nisi illa prius excussa non potest. Nam quo modo an sibi uxor ducenda sit deliberabit Cato nisi constiterit uxores esse ducendas? Et quo modo, an ducere debeat Marciam quaeretur, nisi Catoni ducenda uxor est? 14. Sunt tamen inscripti nomine Hermagorae libri qui confirment illam opinionem, siue falsus est titulus siue alius hic Hermagoras fuit. Nam eiusdem esse quo modo possunt, qui de hac arte mirabiliter multa composuit, cum, sicut ex Ciceronis quoque rhetorico primo manifestum est, materiam rhetorices in thesis et causas diuiserit? Quod reprehendit Cicero ac thesin nihil ad oratorem pertinere contendit totumque hoc genus quaestionis ad philosophos refert. 15. Sed me liberauit respondendi uerecundia et quod ipse hos libros improbat, et quod in Oratore atque iis quos de Oratore scripsit, et Topicis, praecipit ut a propriis personis atque temporibus auocemus controuersiam, quia latius dicere liceat de genere quam de specie, et quod in uniuerso probatum sit, in parte probatum esse necesse sit.

16. Status autem in hoc omne genus materiae idem qui in causas cadunt. Adhuc adicitur alias esse quaestiones in rebus ipsis, alias, quae ad aliquid referantur; illud: an uxor ducenda, hoc: an seni ducenda; illud: an fortis, hoc: an fortior, et similia.

17. Causam finit Apollodorus, ut interpretatione Valgi discipuli eius utar, ita: 'causa est negotium omnibus suis partibus spectans ad quaestionem', aut: 'causa est negotium cuius finis est controuersia.' Ipsum deinde 
negotium sic finit: 'negotium est congregatio personarum, locorum, temporum, causarum, modorum, casuum, factorum, instrumentorum, sermonum, scriptorum, et non scriptorum'. 18. Causam nunc intellegamus

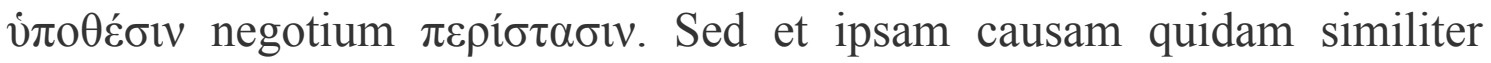
finierunt ut Apollodorus negotium. Isocrates autem causam esse ait quaestionem finitam ciuilem aut rem controuersam in personarum finitarum complexu, Cicero his uerbis: 'causa certis personis locis temporibus actionibus negotiis cernitur, aut in omnibus aut in plerisque eorum'.

[Quid sit status]

1. Ergo cum omnis causa contineatur aliquo statu, prius quam dicere adgredior quo modo genus quodque causae sit tractandum, id quod est commune omnibus, quid sit status et unde ducatur et quot et qui sint intuendum puto. Quamquam id nonnulli ad iudiciales tantum pertinere materias putauerunt; quorum inscitiam, cum omnia tria genera fuero exsecutus, res ipsa deprendet.

2. Quod nos statum, id quidam constitutionem uocant, alii quaestionem, alii quod ex quaestione appareat, Theodorus caput [id est $\kappa \varepsilon \varphi \alpha ́ \lambda \alpha 10 v$ 
$\gamma \varepsilon v i \kappa \omega ́ \tau \alpha \tau o v]$, ad quod referantur omnia. Quorum diuersa appellatio, uis eadem est, nec interest discentium quibus quidque nominibus appelletur,

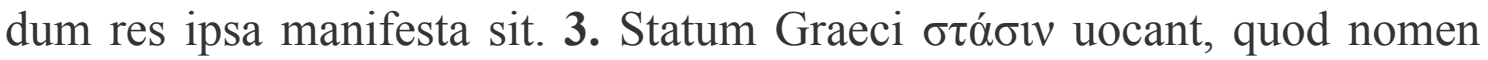
non primum $<$ nulli $>$ ab Hermagora traditum putant, sed alii a Naucrate Isocratis discipulo, alii a Zopyro Clazomenio; quamquam uidetur Aeschines quoque in oratione contra Ctesiphontem uti hoc uerbo, cum a iudicibus petit ne Demostheni permittant euagari, sed eum dicere de ipso causae statu cogant. 4. Quae appellatio dicitur ducta uel ex eo, quod ibi sit primus causae congressus uel quod in hoc causa consistat. Et nominis quidem haec origo: nunc quid sit. Statum quidam dixerunt primam causarum conflictionem: quos recte sensisse, parum elocutos puto. 5. Non enim est status prima conflictio: 'fecisti', 'non feci', sed quod ex prima conflictione nascitur, id est genus quaestionis: 'fecisti', 'non feci', 'an fecerit': 'hoc fecisti', 'non hoc feci', 'quid fecerit'. Quia ex his apparet illud coniectura, hoc finitione quaerendum atque in eo pars utraque insistit, erit quaestio coniecturalis uel finitiui status. 6. Quid si enim dicat quis: 'sonus est duorum inter se corporum conflictio'? Erret, ut opinor; non enim sonus est conflictio, sed ex conflictione. Et hoc leuius (intellegitur enim utcumque dictum). Inde uero ingens male interpretantibus innatus est error, qui, quia primam conflictionem legerant, crediderunt statum semper ex prima quaestione ducendum, quod est uitiosissimum. 7. Nam quaestio nulla non habet utique statum (constat enim ex intentione et depulsione), sed 
aliae sunt propriae causarum de quibus ferenda sententia est, aliae adductae extrinsecus, aliquid tamen ad summam causae conferentes uelut auxilia quaedam; quo fit ut in controuersia una plures quaestiones esse dicantur. 8. Harum porro plerumque leuissima quaeque primo loco fungitur. Namque et illud frequens est, ut ea, quibus minus confidimus, cum tractata sunt, omittamus, interim sponte nostra uelut donantes, interim ad ea quae sunt potentiora, gradum ex iis fecisse contenti.

9. Simplex autem causa, etiamsi uarie defenditur, non potest habere plus uno de quo pronuntietur, atque inde erit status causae, quod et orator praecipue sibi optinendum et iudex spectandum maxime intellegit; in hoc enim causa consistet. 10. Ceterum quaestionum possunt esse diuersi. Quod ut breuissimo pateat exemplo, cum dicit reus: 'Etiam si feci, recte feci', qualitatis utitur statu; cum adicit: 'Sed non feci', coniecturam mouet. Semper autem firmius est non fecisse, ideoque in eo statum esse iudicabo, quod dicerem, si mihi plus quam unum dicere non liceret. 11. Recte igitur est appellata causarum prima conflictio, non quaestionum. Nam et pro Rabirio Postumo Cicero primam partem orationis in hoc intendit, ut actionem competere in equitem Romanum neget; secunda nullam ad eum pecuniam peruenisse confirmat. Statum tamen in eo dicam fuisse, quod est potentius. 12. Nec in causa Milonis circa primas quaestiones [quae sunt ante prohoemium positae], iudicabo conflixisse causam, sed ubi totis uiribus insidiator Clodius ideoque iure interfectus ostenditur. Et hoc est 
quod ante omnia constituere in animo suo debeat orator, etiam si pro causa plura dicturus est, quid maxime liquere iudici uelit. Quod tamen ut primum cogitandum, ita non utique primum dicendum erit.

13. Alii statum crediderunt primam eius, cum quo ageretur, deprecationem. Quam sententiam his uerbis Cicero complectitur: 'In quo primum insistit quasi ad repugnandum congressa defensio'. Vnde rursus alia quaestio, an eum semper is faciat qui respondet. Cui rei praecipue repugnat Cornelius Celsus, dicens non a depulsione sumi, sed ab eo, qui propositionem suam confirmet, ut, si hominem occisum reus negat, status ab accusatore nascatur, quia is uelit probare; si iure occisum reus dicit, tralata probationis necessitate idem a reo fiat et sit eius intentio. 14. Cui non accedo equidem. Nam est uero propius quod contra dicitur, nullam esse litem, si is, cum quo agatur, nihil respondeat, ideoque fieri statum a respondente. 15. Mea tamen sententia uarium id est et accidit pro condicione causarum, quia et uideri potest propositio aliquando statum facere, ut in coniecturalibus causis (utitur enim coniectura magis qui agit, quo moti quidam eundem a reo infitialem esse dixerunt) et in syllogismo tota ratiocinatio ab eo est qui intendit.

16. Sed quia uidetur illic quoque necessitatem hos status exsequendi facere qui negat (is enim si dicat: 'Non feci', coget aduersarium coniectura uti, et si dicat: 'Non habes legem', syllogismo), concedamus ex depulsione nasci statum. Nihilo minus enim res eo reuertetur ut modo is qui agit, modo 
is cum quo agitur statum faciat. 17. Sit enim accusatoris intentio: 'Hominem occidisti'; si negat reus, faciat statum qui negat. Quid si confitetur, sed iure a se adulterum dicit occisum (nempe legem esse certum est quae permittat)? Nisi aliquid accusator respondet, nulla lis est. 'Non fuit, inquit, adulter': ergo depulsio incipit esse actoris, ille statum faciet. Ita erit quidem status ex prima depulsione, sed ea fiet ab accusatore, non a reo. 18. Quid quod eadem quaestio potest eundem uel accusatorem facere uel reum? 'Qui artem ludicram exercuerit, in quattuordecim primis ordinibus ne sedeat'. Qui se praetori in hortis ostenderat neque erat productus, sedit in quattuordecim ordinibus. 19. Nempe intentio est: 'Artem ludicram exercuisti', depulsio: 'Non exercui artem ludicram', quaestio: 'Quid sit artem ludicram exercere'. Si accusabitur theatrali lege, depulsio erit rei; si excitatus fuerit de spectaculis et aget iniuriarum, depulsio erit accusatoris. 20. Frequentius tamen illud accidet quod est a plurimis traditum.

Effugerunt has quaestiones qui dixerunt statum esse id quod appareat ex intentione et depulsione, ut: 'Fecisti'; 'Non feci' aut 'Recte feci'. 21. Viderimus tamen utrum id sit status an in eo status. Hermagoras statum uocat, per quem subiecta res intellegatur et ad quem probationes etiam partium referantur. Nostra opinio semper haec fuit, cum essent frequenter in causa diuersi quaestionum status, in eo credere statum causae quod esset in ea potentissimum et in quo maxime res uerteretur. Id si quis generalem quaestionem uel caput generale dicere malet, cum hoc mihi non erit pugna, 
non magis quam si aliud adhuc, quo idem intellegatur, eius rei nomen inuenerit, quamquam tota uolumina in hanc disputationem inpendisse multos sciam; nobis statum dici placet.

22. Sed cum in aliis omnibus inter scriptores summa dissensio est, tum in hoc praecipue uidetur mihi studium quoque diuersa tradendi fuisse, adeo nec qui sit numerus nec quae nomina nec qui generales quiue speciales sint status conuenit.

23. Ac primum Aristoteles elementa decem constituit, circa quae uersari uideatur omnis quaestio: ovंбıv, quam Plautus essentiam uocat (neque sane aliud est eius nomen Latinum), sed ea quaeritur an sit: 'qualitatem', cuius apertus intellectus est; 'quantitatem', quae dupliciter a posterioribus diuisa est, quam magnum et quam multum sit; 'ad aliquid', unde ductae tralatio et comparatio; 24. post haec 'ubi' et 'quando'; deinde 'facere pati

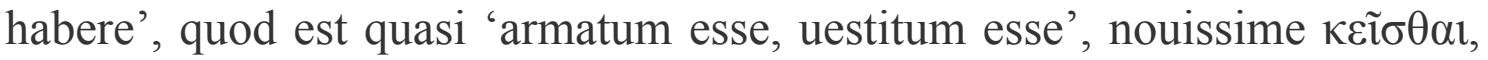
quod est 'compositum esse quodam modo', ut 'iacere stare [irasci]'. Sed ex his omnibus prima quattuor ad status pertinere, cetera ad quosdam locos argumentorum uidentur.

25. Alli nouem elementa posuerunt: personam, in qua de animo, corpore, extra positis quaeratur, quod pertinere ad coniecturae et qualitatis instrumenta uideo; tempus, quod xpóvov uocant, ex quo quaestio an is quem, dum addicta est, mater peperit, seruus sit natus; locum, unde controuersia uidetur an fas fuerit tyrannum in templo occidere, an 
exulauerit qui domi latuit; 26. tempus iterum, quod кaıрóv appellant — hanc autem uideri uolunt speciem illius temporis, ut aestatem uel hiemem; huic subicitur ille in pestilentia comisator; actum, id est $\pi \rho \tilde{\alpha} \xi ı$, quod eo referunt, sciens commiserit an insciens, necessitate an casu, et talia; numerum, qui cadit in speciem quantitatis, 'an Thrasybulo triginta praemia debeantur, qui tot tyrannos sustulerit'; 27. causam, cui plurimae subiacent lites, quotiens factum non negatur, sed quia iusta ratione sit factum,

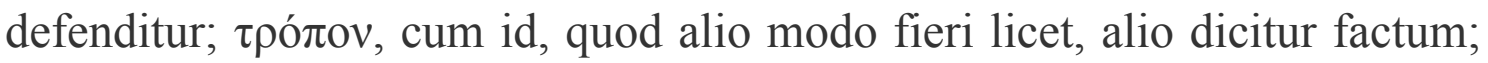
hinc est adulter loris caesus uel fame necatus; occasionem factorum, quod est apertius quam ut uel interpretandum uel exemplo sit demonstrandum;

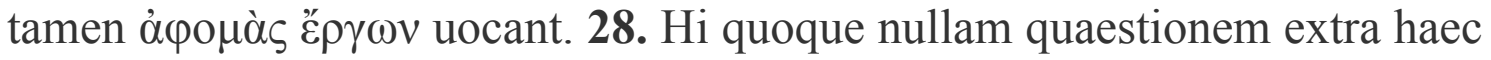
putant. Quidam detrahunt duas partis, numerum et occasionem, et pro illo, quem dixi actum, subiciunt res, id est $\pi \rho \alpha ́ \gamma \mu \alpha \tau \alpha$. Quae ne praeterisse uiderer, satis habui attingere. Ceterum his nec status satis ostendi nec omnis contineri locos credo, quod apparebit diligentius legentibus quae de utraque re dicam; erunt enim plura multo quam quae his elementis comprehenduntur.

29. Apud plures auctores legi placuisse quibusdam unum omnino statum esse coniecturalem, sed quibus placuerit, neque illi tradiderunt neque ego usquam reperire potui. Rationem tamen hanc secuti dicuntur, quod res omnis signis colligeretur. Quo modo licet qualitatis quoque solum statum faciant, quia ubique qualis sit cuiusque rei natura quaeri potest. Sed 
utrocumque modo sequetur summa confusio. 30. Neque interest unum quis statum faciat an nullum, si omnes causae sunt condicionis eiusdem. Coniectura dicta est a coniectu, id est directione quadam rationis ad ueritatem, unde etiam somniorum atque ominum interpretes coniectores uocantur. Appellatum tamen est hoc genus uarie, sicut sequentibus apparebit.

[Quot et qui status]

31. Fuerunt qui duos status facerent; Archedemus coniecturalem et finitiuum, exclusa qualitate, quia sic de ea quaeri existimabat quid esset inicum, quid iniustum, quid dicto audientem non esse. Quod uocat de eodem et alio. 32. Huic diuersa sententia eorum fuit, qui duos quidem status esse uoluerunt, sed unum infitialem, alterum iuridicialem. Infitialis est, quem dicimus coniecturalem, cui ab infitiando nomen alii in totum dederunt, alii in partem, qui accusatorem coniectura, reum infitiatione uti

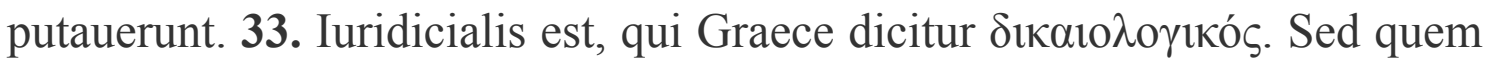
ad modum ab Archedemo qualitas exclusa est, sic ab his repudiata finitio. Nam subiciunt eam iuridiciali, quaerendumque arbitrantur iustumne sit sacrilegium appellari quod obiciatur uel furtum uel amentiam. 34. Qua in opinione Pamphilus fuit, sed qualitatem in plura partitus est.

Plurimi deinceps, mutatis tantum nominibus, in rem de qua non constet, et in rem de qua constet. Nam est uerum nec aliter fieri potest, quam ut aut 
certum sit factum esse quid aut non sit; si non est certum, coniectura sit, si certum est, reliqui status. 35. Nam idem dicit Apollodorus, cum quaestionem aut in rebus extra positis, quibus coniectura explicatur, aut in nostris opinionibus existimat positam, quorum illud $\pi \rho \alpha \gamma \iota \mu \alpha \tau$ Łóv hoc $\pi \varepsilon \rho \grave{~}$

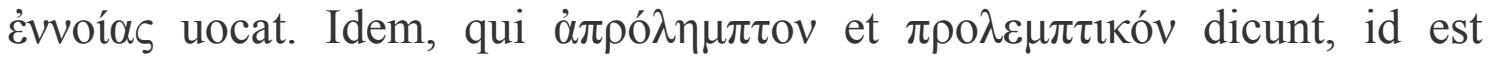
dubium et praesumptum, quo significatur de quo liquet. 36. Idem Theodorus, qui de eo an sit et de accidentibus ei quod esse constat, id est

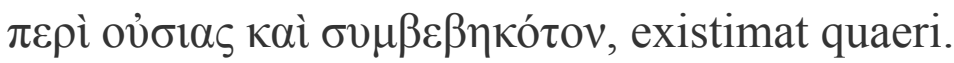

Nam in his omnibus prius genus coniecturam habet, sequens reliqua. Sed haec reliqua Apollodorus duo uult esse, qualitatem et de nomine, id est finitiuam; Theodorus, quid, quale, quantum, ad aliquid. 37. Sunt et qui de eodem et de alio modo qualitatem esse, modo finitionem uelint.

In duo et Posidonius diuidit, uocem et res. In uoce quaeri putat an significet, quid, quam multa, quo modo; rebus coniecturam, quod

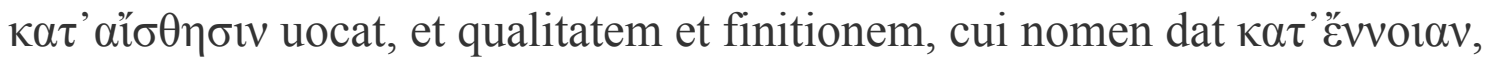
et ad aliquid. Vnde et illa diuisio est, alia esse scripta, alia inscripta. 38. Celsus Cornelius duos et ipse fecit status generales: an sit, quale sit. Priori subiecit finitionem, quia aeque quaeratur an sit sacrilegus, qui nihil se sustulisse de templo dicit, et qui priuatam pecuniam confitetur sustulisse. Qualitatem in rem et scriptum diuidit. Scripto quattuor partes legales exclusa tralatione, quantitatem et mentis quaestionem coniecturae subiecit. 
39. Est etiam illa in duos diuidendi status ratio, quae docet aut de substantia controuersiam esse aut de qualitate, ipsam porro qualitatem aut in summo genere consistere aut in succedentibus. 40. De substantia est coniectura; quaestio enim tractatur rei, an facta sit, an fiat, an futura sit, interdum etiam mentis, idque melius quam quod is placuit, qui statum eundem facti nominauerunt, tamquam de praeterito tantum et tantum de facto quaereretur. 41. Pars qualitatis quae est de summo genere, raro in iudicium uenit, quale est 'idne sit honestum quod uulgo laudatur'. Succedentium autem aliae de communi appellatione, ut: 'Sitne sacrilegus qui pecuniam priuatam ex templo furatus est', aut de re denominata, ubi et factum esse certum est nec dubitatur quid sit quod factum est. Cui subiacent omnes de honestis iustis utilibus quaestiones. 42. His etiam ceteri status contineri dicuntur, quia et quantitas modo ad coniecturam referatur, ut: 'Maiorne sol quam terra', modo ad qualitatem: 'Quanta poena quempiam quantoue praemio sit adfici iustum', et tralatio uersetur circa qualitatem et definitio pars sit tralationis. 43. Quin et contrariae leges et ratiocinatiuus status, id est syllogismos, et plerumque scripti et uoluntatis aequo nitantur, nisi quod hic tertius aliquando coniecturam accipit, quid senserit legis constitutor, ambiguitatem uero semper coniectura explicari necesse sit, quia, cum sit manifestum uerborum intellectum esse duplicem, de sola quaeritur uoluntate. 
44. A plurimis tres sunt facti generales status, quibus et Cicero in Oratore utitur, et omnia, quae aut in controuersiam aut in contentionem ueniant, contineri putat: sitne, quid sit, quale sit. Quorum nomina apertiora sunt quam ut dicenda sint. Idem Iatrocles sentit. 45. Tres fecit et M. Antonius his quidem uerbis: 'Paucae res sunt quibus ex rebus omnes orationes nascuntur, factum non factum, ius iniuria, bonum malum'. Sed quoniam, quod iure dicimur fecisse, non hunc solum intellectum habet, ut lege, sed illum quoque, ut iuste fecisse uideamur, secuti Antonium apertius uoluerunt eosdem status distinguere, itaque dixerunt coniecturalem, legalem, iuridicialem, qui et Verginio placent. 46. Horum deinde fecerunt species, ita ut legali subicerent finitionem et alios, qui ex scripto ducuntur, legum contrariarum, quae antinomia dicitur, et scripti et sententiae uel uoluntatis,

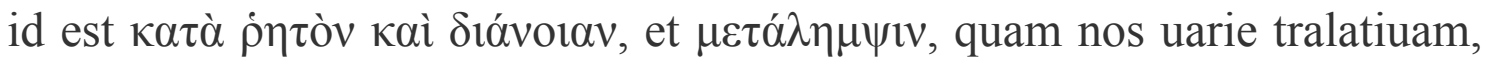

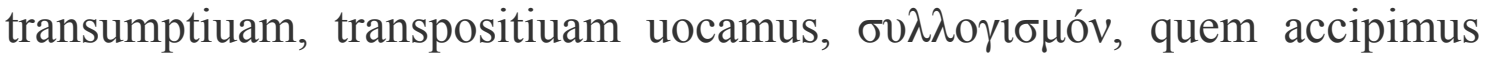
ratiocinatiuum uel collectiuum, ambiguitatis, quae $\dot{\alpha} \mu \varphi \imath \beta$ o $\lambda i ́ \alpha$ nominatur. Quos posui quia et ipsi a plerisque status appellantur, cum quibusdam legales potius quaestiones eas dici placuerit.

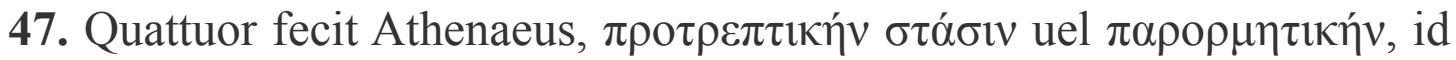
est exhortatiuum, qui suasoriae est proprius, $\sigma v v \tau \varepsilon \lambda \iota \kappa \eta ́ v$, qua coniecturam significari magis ex his quae secuntur quam ex ipso nomine apparet, نं $\alpha \lambda \lambda \alpha \kappa \tau \imath \kappa \eta ́ v$ (ea finitio est, mutatione enim nominis constat), iuridicialem, eadem appellatione Graeca qua ceteri usus. Nam est, ut dixi, 


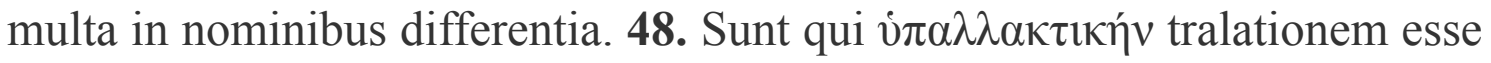
existiment, secuti hanc mutationis significationem. Fecerunt alii totidem status, sed alios, an sit, quid sit, quale sit, quantum sit, ut Caecilius et Theon. 49. Aristoteles in rhetoricis an sit, quale, quantum et quam multum sit quaerendum putat. Quodam tamen loco finitionis quoque uim intellegit, quo dicit quaedam sic defendi: 'Sustuli, sed non furtum feci', 'percussi, sed non iniuriam feci'. 50. Posuerat et Cicero in libris rhetoricis facti, nominis, generis, actionis, ut in facto coniectura, in nomine finitio, in genere qualitas, in actione ius intellegeretur: iuri subiecerat tralationem. Veram hic legales quoque quaestiones alio loco tractat ut species actionis.

51. Fuerunt qui facerent quinque: coniecturam, finitionem, qualitatem, quantitatem, ad aliquid. Theodorus quoque, ut dixi, isdem generalibus capitibus utitur: an sit, quid sit, quale sit, quantum sit, ad aliquid. Hoc ultimum maxime in comparatiuo genere uersari putat, quoniam melius ac peius, maius et minus nisi alio relata non intelleguntur. 52. Sed in illas quoque tralatiuas, ut supra significaui, quaestiones incidit: 'An huic ius agendi sit' uel 'facere aliquid conueniat', 'an contra hunc', 'an hoc tempore', 'an sic'. Omnia enim ista referri ad aliquid necesse est.

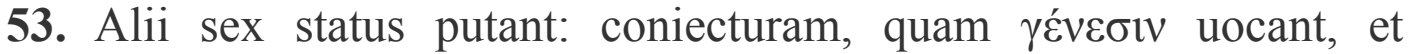
qualitatem et proprietatem, id est iotó $\rceil \tau \alpha$, quo uerbo finitio ostenditur, et quantitatem, quam $\dot{\alpha} \xi \hat{́} \alpha v$ dicunt, et comparationem et tralationem, cuius adhuc nouum nomen inuentum est $\mu \varepsilon \tau \alpha ́ \sigma \tau \alpha \sigma ı$, nouum tamquam in statu, 
alioqui ab Hermagora inter species iuridicialis usitatum. 54. Aliis septem esse placuit, a quibus nec tralatio nec quantitas nec comparatio recepta est, sed in horum trium locum subditae quattuor legales adiectaeque tribus illis rationalibus. 55. Alii peruenerunt usque ad octo tralatione ad septem superiores adiecta. A quibusdam deinde diuisa ratio est, ut status rationales appellarent, quaestiones, quem ad modum supra dixi, legales, in illis de re, in his de scripto quaereretur. Quidam in diuersum hos status esse, illas quaestiones maluerunt. 56. Sed alii rationales tres putauerunt, an sit, quid sit, quale sit, Hermagoras solus quattuor, coniecturam, proprietatem,

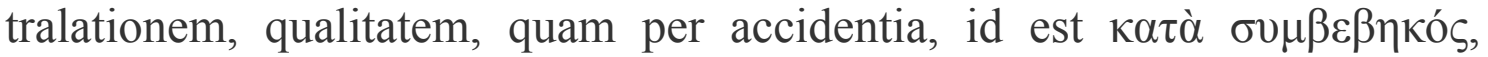
uocat hac interpretatione: 'an illi accidat uiro bono esse uel malo'. Hanc ita diuidit: de adpetendis et fugiendis, quae est pars deliberatiua; de persona

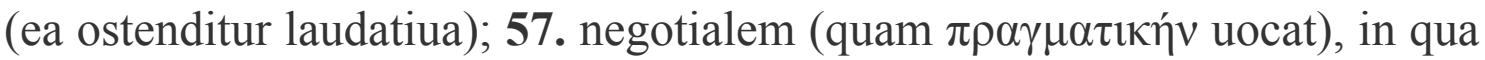
de rebus ipsis quaeritur remoto personarum complexu, ut 'Sitne liber qui est in adsertione', 'An diuitiae superbiam pariant', 'An iustum quid, an bonum sit'; iuridicialem, in qua fere eadem, sed certis destinatisque personis quaerantur: 'An ille iuste hoc fecerit uel bene'.

58. Nec me fallit in primo Ciceronis rhetorico aliam esse loci negotialis interpretationem, cum ita scriptum sit: 'Negotialis est in qua, quid iuris ex ciuili more et aequitate sit, consideratur; cui diligentiae praeesse apud nos iure consulti existimantur.' 59. Sed quod ipsius de his libris iudicium fuerit supra dixi. Sunt enim uelut regestae in hos commentarios, quos adulescens 
deduxerat, scholae, et si qua est in his culpa, tradentis est, siue eum mouit quod Hermagoras prima in hoc loco posuit exempla ex quaestionibus iuris, siue quod Graeci $\pi \rho \alpha \gamma \mu \alpha \tau$ quidem his pulcherrimos illos de oratore substituit, ideoque culpari, tamquam falsa praecipiat non potest. Nos ad Hermagoran. Tralationem hic primus omnium tradidit, quamquam semina eius quaedam citra nomen ipsum apud Aristotelen reperiuntur. 61. Legales autem quaestiones has

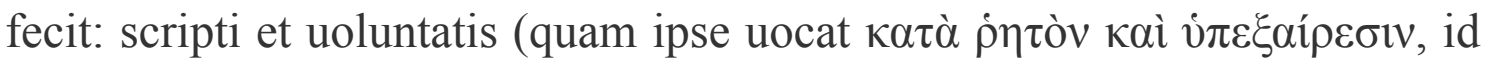
est dictum et exceptionem; quorum prius ei cum omnibus commune est, exceptionis nomen minus usitatum), ratiocinatiuum, ambiguitatis, legum contrariarum. 62. Albucius eadem diuisione usus detrahit tralationem, subiciens eam iuridiciali. In legalibus quoque quaestionibus nullum putat esse qui dicatur ratiocinatiuus. Scio plura inuenturos adhuc, qui legere antiquos studiosius uolent, sed ne haec quoque excesserint modum uereor.

63. Ipse me paulum in alia, quam prius habuerim, opinione nunc esse confiteor. Et fortasse tutissimum erat famae modo studenti nihil ex eo mutare, quod multis annis non sensissem modo, uerum etiam adprobassem. 64. Sed non sustineo esse conscius mihi dissimulati, in eo praesertim opere, quod ad bonorum iuuenum aliquam utilitatem componimus, in ulla parte iudicii mei. Nam et Hippocrates, clarus arte medicinae, uidetur honestissime fecisse, quod quosdam errores suos, ne posteri errarent, confessus est, et M. Tullius non dubitauit aliquos iam editos libros aliis 
postea scriptis ipse damnare, sicut Catulum atque Lucullum et hos ipsos, de quibus modo sum locutus, artis rhetoricae. 65. Etenim superuacuus foret in studiis longior labor, si nihil liceret melius inuenire praeteritis. Neque tamen quicquam ex iis, quae tum praecepi, superuacuum fuit; ad easdem enim particulas haec quoque quae nunc praecipiam reuertentur. Ita neminem didicisse paeniteat: colligere tantum eadem ac disponere paulo significantius conor. Omnibus autem satis factum uolo, non me hoc serius demonstrare aliis, quam mihi ipse persuaserim.

66. Secundum plurimos auctores seruabam tris rationales status: coniecturam, qualitatem, finitionem, unum legalem. Hi mihi status generales erant. Legalem in quinque species partiebar: scripti et uoluntatis, legum contrariarum, collectiuum, ambiguitatis, tralationis. 67. Nunc quartum ex generalibus intellego posse remoueri; sufficit enim prima diuisio, qua diximus alios rationales, alios legales esse; ita non erit status, sed quaestionum genus; alioqui et rationalis status esset. 68. Ex iis etiam, quos speciales uocabam, remoui tralationem, frequenter quidem (sicut omnes, qui me secuti sunt, meminisse possunt) testatus, et in ipsis etiam illis sermonibus me nolente uulgatis hoc tamen complexus, uix in ulla controuersia tralationis statum posse reperiri, ut non et alius in eadem recte dici uideretur, ideoque a quibusdam eum exclusum. 69. Neque ignoro multa transferri, cum in omnibus fere causis, in quibus cecidisse quis formula dicitur, hae sint quaestiones: 'An huic? An cum hoc? An hac lege? 
An apud hunc? An hoc tempore liceat agere', et si qua sunt talia. 70. Sed personae, tempora, actiones ceteraque propter aliquam causam transferuntur; ita non est in tralatione quaestio, sed in eo propter quod transferuntur. 'Non debes apud praetorem petere fidei commissum, sed apud consules: maior enim praetoria cognitione summa est.' Quaeritur an maior summa sit: facti controuersia est. 71. 'Non licet tibi agere mecum: cognitor enim fieri non potuisti': iudicatio an potuerit. 'Non debuisti interdicere, sed petere': an recte interdictum sit ambigitur. Quae omnia succidunt legitimis quaestionibus.

72. An non praescriptiones, etiam in quibus maxime uidetur manifesta tralatio, easdem omnes species habent, quas eae leges, quibus agitur, ut aut de nomine aut scripto et sententia uel ratiocinatione quaeratur? Deinde status ex quaestione oritur: tralatio non habet quaestionem de qua contendit orator, sed propter quam contendit. 73. Hoc apertius: 'Occidisti hominem'; 'Non occidi': quaestio an occiderit, status coniectura. Non est tale 'Habeo ius actionis'; 'Non habes', ut sit quaestio an habeat, et inde status. Accipiat enim actionem necne ad euentum pertinet, non ad causam, et ad id, quod pronuntiat iudex, non id propter quod pronuntiat. 74. Hoc illi simile est 'Puniendus es'; 'Non sum'; uidebit iudex an puniendus sit, sed non hic erit quaestio nec hic status. Vbi ergo? 'Puniendus es, hominem occidisti': 'Non occidi'. An occiderit. 'Honorandus sum': 'Non es' num statum habet? Non, ut puto. 'Honorandus sum, quia tyrannum occidi': 'Non occidisti'. 
Quaestio et status. Similiter: 'Non recte agis'; 'Recte ago' non habet statum. 75. Vbi est ergo? 'Non recte agis ignominiosus'. Quaeritur an ignominiosus sit, aut an agere ignominioso liceat; quaestiones et status. Ergo tralatiuum genus causae, ut comparatiuum et mutuae accusationis.

76. At enim simile est illi: 'Habeo ius'.—- Non habes' hoc 'Occidisti'.— 'Recte occidi'. Non nego, sed nec haec res statum facit; non enim sunt hae propositiones (alioqui causa non explicabitur), sed cum suis rationibus. 'Scelus commisit Horatius; sororem enim occidit'-'Non commisit; debuit enim occidere eam, quae hostis morte maerebat'. Quaestio, an haec iusta causa; ita qualitas. 77. Ac similiter in tralatione: 'Non habes ius abdicandi, quia ignominioso non est actio'.-- 'Habeo ius, quia abdicatio actio non est'. Quaeritur quid sit actio; finiemus 'Non licet abdicare filium' syllogismo. Item cetera per omnes et rationales et legales status.

78. Nec ignoro fuisse quosdam, qui tralationem in rationali quoque genere ponerent hoc modo: 'Hominem occidi iussus ab imperatore'; 'Dona templi cogenti tyranno dedi'; 'Deserui tempestatibus, fluminibus, ualetudine impeditus', id est, non per me stetit, sed per illud. 79. A quibus etiam liberius dissentio; non enim actio transfertur, sed causa facti, quod accidit paene in omni defensione. Deinde is qui tali utitur patrocinio non recedit a forma qualitatis; dicit enim se culpa uacare, ut magis qualitatis duplex ratio facienda sit, altera qua et factum defenditur, altera qua tantum reus. 
80. Credendum est igitur iis quorum auctoritatem secutus est Cicero, tria esse, quae in omni disputatione quaerantur: an sit, quid sit, quale sit. Quod ipsa nobis etiam natura praescribit: nam primum oportet subesse aliquid, de quo ambigitur, quod, quid sit et quale sit, certe non potest aestimari, nisi prius esse constiterit; ideoque ea prima quaestio. 81. Sed non statim, quod esse manifestum est, etiam quid sit apparet. Hoc quoque constituto nouissima qualitas superest, neque his exploratis aliud est ultra. His infinitae quaestiones, his finitae continentur; horum aliqua in demonstratiua, deliberatiua, iudiciali materia utique tractatur. 82. Haec rursus iudicialis causas et rationali parte et legali continent. Neque enim ulla iuris disceptatio nisi finitione, qualitate, coniectura potest explicari. 83. Sed instituentibus rudes non erit inutilis latius primo fusa ratio, et, si non statim rectissima linea tensa, facilior tamen et apertior uia.

Discant igitur ante omnia quadripertitam in omnibus causis esse rationem, quam primam intueri debeat qui acturus est. Nam ut a defensore potissimum incipiam, longe fortissima tuendi se ratio est, si, quod obicitur, negari potest; proxima, si non id, quod obicitur, factum esse dicitur; tertia honestissima, qua recte factum defenditur. Quibus si deficiamur, ultima quidem, sed iam sola superest salus aliquo iuris adiutorio elabendi ex crimine quod neque negari neque defendi potest, ut non uideatur iure actio intendi. 84. Hinc illae quaestiones siue actionis siue tralationis. Sunt enim quaedam non laudabilia natura, sed iure concessa, ut in duodecim tabulis 
debitoris corpus inter creditores diuidi licuit, quam legem mos publicus repudiauit; et aliquid aecum, sed prohibitum iure, ut libertas testamentorum. 85. Accusatori nihilo plura intuenda sunt, ut probet factum esse, hoc esse factum, non recte factum, iure se intendere. Ita circa species easdem lis omnis uersabitur, tralatis tantum aliquando partibus, ut in causis, quibus de praemio agitur, recte factum petitor probat.

86. Haec quattuor uelut proposita formaeque actionis, quae tum generales status uocabam, in duo, ut ostendi, genera discedunt, rationale et legale. Rationale simplicius est, quia ipsius tantum naturae contemplatione constat; itaque in eo satis est ostendisse coniecturam, finitionem, qualitatem. 87. Legalium plures sint species necesse est, propterea quod multae sunt leges et uarias habent formas. Alia est cuius uerbis nitimur, alia cuius uoluntate; alias nobis, cum ipsi nullam habeamus, adiungimus, alias inter se comparamus, alias in diuersum interpretamur.

88. Sic nascuntur haec uelut simulacra ex illis tribus, interim simplicia, interim et mixta, propriam tamen faciem ostendentia, ut scripti et uoluntatis, quae sine dubio aut qualitate aut coniectura continentur, et $\sigma v \lambda \lambda \gamma_{\gamma} \sigma \mu o_{\zeta}$, qui est maxime qualitatis, et leges contrariae, quae isdem quibus scriptum et uoluntas constant, et $\alpha \mu \varphi \imath \beta o \lambda i ́ \alpha$, quae semper coniectura explicatur. 89. Finitio quoque utrique generi, quodque rerum quodque scripti contemplatione constat, communis est. Haec omnia, etiamsi in illos tres status ueniunt, tamen, quia, ut dixi, habent aliquid uelut proprium, 
uidentur demonstranda discentibus, et permittendum ea dicere uel status legales uel quaestiones uel capita quaedam minora, dum sciant nihil ne in his quidem praeter tria, quae praediximus quaeri. 90. At quantum, et quam multum, et ad aliquid, et, ut nonnulli putarunt, comparatiuus non eandem rationem habent: sunt enim haec non ad uarietatem iuris, sed ad solam rationem referenda. Ideoque semper in parte aut coniecturae aut qualitatis ponenda sunt, ut qua mente? et quo tempore? et quo loco?

91. Sed de singulis dicemus quaestionibus, cum tractare praecepta diuisionis coeperimus.

Hoc inter omnes conuenit, in causis simplicibus singulos status esse causarum, quaestionum autem, quae uelut subiacent his, et ad illud, quo iudicium continetur, referuntur, saepe in unam cadere plures posse. 92. Etiam credo aliquando dubitari quo statu sit utendum, cum aduersus unam intentionem plura opponuntur, et sicut in colore dicitur narrationis eum esse optimum, quem actor optime tueatur, ita hic quoque posse dici eum statum esse faciendum, in quo tuendo plurimum adhibere uirium possit orator. $\mathbf{9 3 .}$ Ideoque pro Milone aliud Ciceroni agenti placuit, aliud Bruto, cum exercitationis gratia componeret orationem, cum ille iure tamquam insidiatorem occisum et tamen non Milonis consilio dixerit, ille etiam gloriatus sit occiso malo ciue. 94. In coniunctis uero posse duos et tris inueniri, uel diuersos, ut si quis aliud se non fecisse, aliud recte fecisse defendat, uel generis eiusdem, ut si quis duo crimina uel omnia neget. 95. 
Quod accidit etiam, si de una re quaeratur aliqua, sed eam plures petant, uel eodem iure, ut proximitatis, uel diuerso, ut cum hic testamento, ille proximitate nitetur.

Quotiens autem aliud alii petitori opponitur, dissimilis esse status necesse est, ut in illa controuersia. 96. 'Testamenta legibus facta rata sint; intestatorum parentium liberi heredes sint; abdicatus ne quid de bonis patris capiat; nothus ante legitimum natus legitimus filius sit, post legitimum natus, tantum ciuis; in adoptionem dare liceat; in adoptionem dato redire in familiam liceat, si pater naturalis sine liberis decesserit. 97. Qui ex duobus legitimis alterum in adoptionem dederat, alterum abdicauerat, sustulit nothum; instituto herede abdicato decessit. Tres omnes de bonis contendunt'. Nothum qui non sit legitimus Graeci uocant, Latinum rei nomen, ut Cato quoque in oratione quadam testatus est, non habemus, ideoque utimur peregrino; sed ad propositum.

98. Heredi scripto opponitur lex: 'Abdicatus ne quid de bonis patris capiat'; fit status scripti et uoluntatis, an ullo modo capere possit, an ex uoluntate patris, an heres scriptus.

Notho duplex fit quaestio, quod post legitimos natus sit, et quod non sit ante legitimum natus. 99. Prior $\sigma 0 \lambda \lambda \sigma \gamma 1 \sigma \mu o ́ v$ habet: an pro non natis sint habendi, qui a familia sunt alienati? Altera scripti et uoluntatis. Non esse enim hunc natum ante legitimum conuenit, sed uoluntate legis se tuebitur, quam dicet talem fuisse, ut legitimus esset nothus tum natus, cum alius 
legitimus in domo non esset. 100. Scriptum quoque legis excludet, dicens, non utique, si postea legitimus natus non sit, notho nocere, uteturque hoc argumento: 'Finge solum natum nothum, cuius condicionis erit? Tantum ciuis? Atqui non erit post legitimum natus. An filius? Atqui non erit ante legitimum natus. Quare si uerbis legis stari non potest, uoluntate standum est'.

101. Nec quemquam turbet, quod ex una lege duo status fiant: duplex est, ita uim duarum habet. Redire in familiam uolenti dicitur ab altero primum: 'Vt tibi redire liceat, heres sum'. Idem status, qui in petitione abdicati: quaeretur enim an possit esse heres abdicatus. 102. Adicitur communiter a duobus: 'Redire tibi in familiam non licet; non enim pater sine liberis decessit'. Sed in hoc propria quisque eorum quaestione nitetur. Alter enim dicet abdicatum quoque inter liberos esse, et argumentum ducet ex ipsa, qua repellitur, lege; superuacuum enim fuisse prohiberi patris bonis abdicatum, si esset numero alienorum; nunc, quia filii iure futurus fuerit intestati heres, oppositam esse legem, quae tamen non id efficiat ne filius sit, sed ne heres sit. 103. Status finitiuus: quid sit filius. Rursus nothus eisdem colligit argumentis non sine liberis patrem decessisse, quibus in petitione usus est, ut probaret esse se filium, nisi forte et hic finitionem mouet: an liberi sint etiam non legitimi.

Cadent ergo in unam controuersiam uel specialiter duo legitimi status, scripti et uoluntatis et syllogismos, et praeterea finitio, uel tres illi, qui 
natura soli sunt, coniectura in scripto et uoluntate, qualitas in syllogismo et, quae per se est aperta, finitio.

104. Causa quoque et iudicatio et continens est in omni genere causarum. Nihil enim dicitur, cui non insit ratio et quo iudicium referatur, et quod rem maxime contineat. Sed quia magis haec uariantur in litibus et fere tradita sunt ab iis qui de iudicialibus causis aliqua composuerunt, in illam partem differantur. Nunc, quia in tria genera causas diuisi, ordinem sequar.

\section{VII}

[De laude et uituperatione]

1. Ac potissimum incipiam ab ea quae constat laude ac uituperatione. Quod genus uidetur Aristoteles atque eum secutus Theophrastus a parte negotiali, hoc est $\pi \rho \alpha \gamma \mu \alpha \tau i \mathfrak{n}$, remouisse, totamque ad solos auditores relegasse; et id eius nominis quod ab ostentatione ducitur, proprium est. 2. Sed mos Romanus etiam negotiis hoc munus inseruit. Nam et funebres laudationes pendent frequenter ex aliquo publico officio atque ex senatus consulto magistratibus saepe mandantur, et laudare testem uel contra pertinet ad momentum iudiciorum, et ipsis etiam reis dare laudatores licet, et editi in competitores, in L. Pisonem, in Clodium et Curionem libri uituperationem continent et tamen in senatu loco sunt habiti sententiae. $\mathbf{3}$. 
Neque infitias eo quasdam esse ex hoc genere materias ad solam compositas ostentationem, ut laudes deorum uirorumque, quos priora tempora tulerunt. Quo soluitur quaestio supra tractata, manifestumque est errare eos qui numquam oratorem dicturum nisi de re dubia putauerunt. 4. An laudes Capitolini Iouis, perpetua sacri certaminis materia, uel dubiae sunt uel non oratorio genere tractantur?

Vt desiderat autem laus, quae negotiis adhibetur, probationem, sic etiam illa, quae ostentationi componitur, habet interim aliquam speciem probationis, 5. ut qui Romulum Martis filium educatumque a lupa dicat, in argumentum caelestis ortus utatur his, quod abiectus in profluentem non potuerit extingui, quod omnia sic egerit ut genitum praeside bellorum deo incredibile non esset, quod ipsum quoque caelo receptum temporis eius homines non dubitauerint. 6. Quaedam uero etiam in defensionis speciem cadent, ut si in laude Herculis permutatum cum regina Lydiae habitum et imperata, ut traditur, pensa orator excuset. Sed proprium laudis est res amplificare et ornare.

Quae materia praecipue quidem in deos et homines cadit, est tamen et aliorum animalium; et etiam carentium anima. 7. Verum in deis generaliter primum maiestatem ipsius eorum naturae uenerabimur, deinde proprie uim cuiusque et inuenta quae utile aliquid hominibus attulerint. 8. Vis ostendetur ut in Ioue regendorum omnium, in Marte belli, in Neptuno maris; inuenta, ut artium in Minerua, Mercurio litterarum, medicinae 
Apolline, Cerere frugum, Libero uini. Tum si qua ab iis acta uetustas tradidit, commemoranda. Addunt etiam dis honorem parentes, ut si quis sit filius Iouis; addit antiquitas, ut $i$ is, qui sunt ex Chao, progenies quoque, ut Apollo ac Diana Latonae. 9. Laudandum in quibusdam quod geniti inmortales, quibusdam, quod inmortalitatem uirtute sint consecuti; quod pietas principis nostri praesentium quoque temporum decus fecit.

10. Magis est uaria laus hominum. Nam primum diuiditur in tempora, quodque ante eos fuit quoque ipsi uixerunt, in iis autem qui fato sunt functi etiam quod est insecutum. Ante hominem patria ac parentes maioresque erunt, quorum duplex tractatus est: aut enim respondisse nobilitati pulchrum erit aut humilius genus inlustrasse factis. 11. Illa quoque interim ex eo, quod ante ipsum fuit, tempore trahentur, quae responsis uel auguriis futuram claritatem promiserint, ut eum, qui ex Thetide natus esset, maiorem patre suo futurum cecinisse dicuntur oracula. 12. Ipsius uero laus hominis ex animo et corpore et extra positis peti debet. Et corporis quidem fortuitorumque cum leuior, tum non uno modo tractanda est. Nam et pulchritudinem interim roburque prosequimur honore uerborum, ut Homerus in Agamemnone atque Achille, interim confert admirationi multum etiam infirmitas, ut cum idem Tydea paruum, sed bellatorem dicit fuisse. 13. Fortuna uero tum dignitatem adfert, ut in regibus principibusque (namque est haec materia ostendendae uirtutis uberior), tum, quo minores opes fuerunt, maiorem benefactis gloriam parit. Sed omnia, quae extra nos 
bona sunt quaeque hominibus forte optigerunt, non ideo laudantur quod habuerit quis ea, sed quod $i$ is honeste sit usus. 14. Nam diuitiae et potentia et gratia, cum plurimum uirium dent, in utramque partem certissimum faciunt morum experimentum: aut enim meliores propter haec aut peiores sumus. 15. Animi semper uera laus, sed non una per hoc opus uia ducitur. Namque alias aetatis gradus gestarumque rerum ordinem sequi speciosius fuit, ut in primis annis laudaretur indoles, tum disciplinae, post hoc operum (id est factorum dictorumque) contextus, alias in species uirtutum diuidere laudem, fortitudinis, iustitiae, continentiae, ceterarumque, ac singulis adsignare quae secundum quamque earum gesta erunt. 16. Vtra sit autem harum uia utilior, cum materia deliberabimus, dum sciamus gratiora esse audientibus quae solus quis aut primus aut certe cum paucis fecisse dicetur, si quid praeterea supra spem aut expectationem, praecipue quod aliena potius causa quam sua. 17. Tempus, quod finem hominis insequitur, non semper tractare contingit: non solum quod uiuentes aliquando laudamus, sed quod rara haec occasio est, ut referri possint diuini honores et decreta et publice statuae constitutae. 18. Inter quae numerauerim ingeniorum monumenta, quae saeculis probarentur; nam quidam, sicut Menander, iustiora posterorum quam suae aetatis iudicia sunt consecuti. Adferunt laudem liberi parentibus, urbes conditoribus, leges latoribus, artes inuentoribus, nec non instituta quoque auctoribus, ut a Numa traditum deos colere, a Publicola fasces populo summittere. 
19. Qui omnis etiam in uituperatione ordo constabit, tantum in diuersum. Nam et turpitudo generis opprobrio multis fuit, et quosdam claritas ipsa notiores circa uitia et inuisos magis fecit, et in quibusdam, ut in Paride traditur, est praedicta pernicies, et corporis ac fortunae quibusdam mala contemptum, sicut Thersitae atque Iro, quibusdam bona uitiis corrupta odium attulerunt, ut Nirea inbellem, Plisthenen inpudicum a poetis accepimus. 20. Et animi totidem uitia quot uirtutes sunt, nec minus quam in laudibus duplici ratione tractantur. Et post mortem adiecta quibusdam ignominia est, ut Maelio, cuius domus solo aequata, Marcoque Manlio, cuius praenomen e familia in posterum exemptum est. 21. Et parentes malorum odimus; et est conditoribus urbium infame contraxisse aliquam perniciosam ceteris gentem, qualis est primus Iudaicae superstitionis auctor; et Gracchorum leges inuisae, et si quod est exemplum deforme posteris traditum, quale libidinis uir Perses in muliere Samia instituere ausus dicitur primus. 22. Sed in uiuentibus quoque iudicia hominum uelut argumenta sunt morum, et honos aut ignominia ueram esse laudem uel uituperationem probat.

23. Interesse tamen Aristoteles putat, ubi quidque laudetur aut uituperetur. Nam plurimum refert qui sint audientium mores, quae publice recepta persuasio, ut illa maxime quae probant esse in eo, qui laudabitur, credant, aut in eo, contra quem dicemus, ea quae oderunt; ita non dubium erit iudicium, quod orationem praecesserit. 24. Ipsorum etiam permiscenda laus 
semper (nam id beniuolos facit); quotiens autem fieri poterit, cum materiae utilitate iungenda.

Minus Lacedaemone studia litterarum quam Athenis honoris merebuntur, plus patientia ac fortitudo. Rapto uiuere quibusdam honestum, aliis cura legum. Frugalitas apud Sybaritas forsitan odio foret, ueteribus Romanis summum luxuria crimen. 25. Eadem in singulis differentia. Maxime fauet iudex, qui sibi dicentem adsentari putat. Idem praecipit illud quoque, quod mox Cornelius Celsus prope supra modum inuasit, quia sit quaedam uirtutibus ac uitiis uicinitas, utendum proxima deriuatione uerborum, ut pro temerario fortem, pro prodigo liberalem, pro auaro parcum uocemus: quae eadem etiam contra ualent. Quod quidem orator, id est uir bonus, numquam faciet, nisi forte communi utilitate ducetur.

26. Laudantur autem urbes similiter atque homines. Nam pro parente est conditor, et multum auctoritatis adfert uetustas, ut iis, qui terra dicuntur orti, et uirtutes ac uitia circa res gestas eadem quae in singulis: illa propria, quae ex loci positione ac munitione sunt. Ciues illis ut hominibus liberi sunt decori. 27. Est laus et operum, in quibus honor, utilitas, pulchritudo, auctor spectari solet, honor ut in templis, utilitas ut in muris, pulchritudo uel auctor utrubique. Est et locorum, qualis Siciliae apud Ciceronem, in quibus similiter speciem et utilitatem intuemur, speciem maritimis, planis, amoenis, utilitatem salubribus fertilibus. Erit et dictorum honestorum 
factorumque laus generalis, erit et rerum omnis modi. 28. Nam et somni et mortis scriptae laudes et quorundam a medicis ciborum.

Itaque, ut non consensi hoc laudatiuum genus circa solam uersari honesti quaestionem, sic qualitate maxime contineri puto, quamquam tres status omnes cadere in hoc opus possint, iisque usum C. Caesarem in uituperando Catone notauerit Cicero. Totum autem habet aliquid simile suasoriis, quia plerumque eadem illic suaderi, hic laudari solent.

\section{VIII}

[De suasoria et prosopopeia]

1. Deliberatiuas quoque miror a quibusdam sola utilitate finitas. Ac si quid in his unum sequi oporteret, potior fuisset apud me Ciceronis sententia, qui hoc materiae genus dignitate maxime contineri putat. Nec dubito quin ii qui sunt in illa priore sententia, secundum opinionem pulcherrimam, ne utile quidem, nisi quod honestum esset existimarint. 2. Et est haec ratio uerissima, si consilium contingat semper bonorum atque sapientium. Verum apud imperitos, apud quos frequenter dicenda sententia est, populumque praecipue, qui ex pluribus constat indoctis, discernenda sunt haec et secundum communes magis intellectus loquendum. 3. Sunt enim multi qui etiam quae credunt honesta, non tamen satis eadem utilia quoque existiment, et, quae turpia esse dubitare non possunt, utilitatis specie ducti probent, ut foedus Numantinum iugumque Caudinum. 
4. Ne qualitatis quidem statu, in quo et honestorum et utilium quaestio est, complecti eas satis est. Nam frequenter in his etiam coniecturae locus est: nonnumquam tractatur aliqua finitio, aliquando etiam legales possunt incidere tractatus, in priuata maxime consilia, si quando ambigetur an liceat. 5. De coniectura paulo post pluribus. Interim est finitio apud Demosthenen det Halonnesum Philippus an reddat, apud Ciceronem in Philippicis quid sit tumultus. Quid? non illa similis iudicialium quaestio de statua Serui Sulpici, an iis demum ponenda sit qui in legatione ferro sunt interempti? 6. Ergo pars deliberatiua, quae eadem suasoria dicitur, de tempore futuro consultans quaerit etiam de praeterito. Officiis constat duobus suadendi ac dissuadendi.

Prohoemio, quale est in iudicialibus, non ubique eget, quia conciliatus est ei quisque, quem consulit. Initium tamen quodcumque debet habere aliquam prohoemii speciem; neque enim abrupte nec unde libuit incipiendum, quia est aliquid in omni materia naturaliter primum. 7. In senatu et utique in contionibus eadem ratio quae apud iudices, adquirendae sibi plerumque eorum, apud quos dicendum sit, beniuolentiae. Nec mirum, cum etiam in panegyricis petatur audientium fauor, ubi emolumentum non utilitate aliqua, sed in sola laude consistit. 8. Aristoteles quidem, nec sine causa, putat et a nostra et ab eius, qui dissentiet persona duci frequenter in consiliis exordium, quasi mutuantibus hoc nobis a iudiciali genere, nonnumquam etiam, ut minor res maiorue uideatur; in demonstratiuis uero 
prohoemia esse maxime libera existimat. 9. Nam et longe a materia duci, ut in Helenae laude Isocrates fecerit, et ex aliqua rei uicinia, ut idem in Panegyrico, cum queritur plus honoris corporum quam animorum uirtutibus dari, et Gorgias in Olympico laudans eos qui primi tales instituerint conuentus. Quos secutus uidelicet C. Sallustius in bello Iugurthino et Catilinae nihil ad historiam pertinentibus principiis orsus est.

10. Sed nunc ad suasoriam, in qua, etiam cum prohoemio utemur, breuiore tamen et uelut quodam capite tantum et initio debebimus esse contenti. Narrationem uero numquam exigit priuata deliberatio, eius dumtaxat rei de qua dicenda sententia est, quia nemo ignorat id, de quo consulit. 11. Extrinsecus possunt pertinentia ad deliberationem multa narrari. In contionibus saepe est etiam illa, quae ordinem rei docet, necessaria. 12. Adfectus ut quae maxime postulat: nam et concitanda et lenienda frequenter est ira, et ad metum, cupiditatem, odium, conciliationem inpellendi animi. Nonnumquam etiam mouenda miseratio, siue, ut auxilium obsessis feratur, suadere oportebit, siue sociae ciuitatis euersionem deflebimus. Valet autem in consiliis auctoritas plurimum. 13. Nam et prudentissimus esse haberique et optimus debet, qui sententiae suae de utilibus atque honestis credere omnes uelit. In iudiciis enim uulgo fas habetur indulgere aliquid studio suo; consilia nemo est qui neget secundum mores dari. 
14. Graecorum quidem plurimi omne hoc officium contionale esse iudicauerunt et in sola rei publicae administratione posuerunt; quin et Cicero in hac maxime parte uersatur. Ideoque suasuris de pace, bello, copiis, operibus, uectigalibus haec duo esse praecipue nota uoluit, uires ciuitatis et mores, ut ex natura cum ipsarum rerum, tum audientium ratio suadendi duceretur. 15. Nobis maior in re uidetur uarietas; nam et consultantium et consiliorum plura sunt genera.

Quare in suadendo ac dissuadendo tria primum spectanda erunt: quid sit de quo deliberetur, qui sint qui deliberent, qui sit qui suadeat. 16. Rem, de qua deliberatur, aut certum est posse fieri aut incertum. Si incertum, haec erit quaestio sola aut potentissima; saepe enim accidet ut prius dicamus, ne si possit quidem fieri, esse faciendum, deinde, fieri non posse. Cum autem de hoc quaeritur, coniectura est: an Isthmos intercidi, an siccari palus Pomptina, an portus fieri Ostiae possit, an Alexander terras ultra Oceanum sit inuenturus. 17. Sed in iis quoque, quae constabit posse fieri, coniectura aliquando erit, si quaeretur an utique futurum sit ut Carthaginem superent Romani, ut redeat Hannibal, si Scipio exercitum in Africam transtulerit, ut seruent fidem Samnites, si Romani arma deposuerint. Quaedam et fieri posse et futura esse credibile est, sed aut alio tempore aut alio loco aut alio modo.

18. Vbi coniecturae non erit locus, alia sunt intuenda. Et primum aut propter ipsam rem, de qua sententiae rogantur, consultabitur, aut propter 
alias interuenientes extrinsecus causas. Propter ipsam: 'Deliberant patres conscripti an stipendium militi constituant.' 19. Haec materia simplex erit. Accedunt causae aut faciendi (ut 'deliberant patres conscripti an Fabios dedant Gallis bellum minitantibus') aut non faciendi: 'deliberat C. Caesar an perseueret in Germaniam ire, cum milites passim testamenta facerent.' 20. Hae suasoriae duplices sunt. Nam et illic causa deliberandi est, quod bellum Galli minitentur, esse tamen potest quaestio, dedendine fuerint etiam citra hanc denuntiationem, qui contra fas, cum legati missi essent, proelium inierint, regemque, ad quem mandata acceperant, trucidarint. 21. Et hic nihil Caesar sine dubio deliberaret nisi propter hanc militum perturbationem; est tamen locus quaerendi an citra hunc quoque casum penetrandum in Germaniam fuerit. Semper autem de eo prius loquemur de quo deliberari etiam detractis sequentibus possit.

22. Partes suadendi quidam putauerunt honestum, utile, necessarium. Ego non inuenio huic tertiae locum. Quantalibet enim uis ingruat, aliquid fortasse pati necesse sit, nihil facere, de faciendo autem deliberatur. 23. Quod si hanc uocant necessitatem, in quam homines grauiorum metu coguntur, utilitatis erit quaestio, ut si obsessi et inpares et aqua ciboque defecti de facienda ad hostem deditione deliberent et dicatur 'necesse est'; nempe sequitur ut hoc subiciatur: 'alioqui pereundum est': ita propter id ipsum non est necesse, quia perire potius licet. Denique non fecerunt Saguntini nec in rate Opitergina circumuenti. 24. Igitur in his quoque causis 
aut de sola utilitate ambigetur aut quaestio inter utile atque honestum consistet. At enim, si quis liberos procreare uolet, necesse habet ducere uxorem. Quis dubitat? Sed ei, qui pater uult fieri, liqueat necesse est uxorem esse ducendam. 25. Itaque mihi ne consilium quidem uidetur, ubi necessitas est, non magis quam ubi constat quid fieri non posse: omnis enim deliberatio de dubiis est. Melius igitur, qui tertiam partem duxerunt

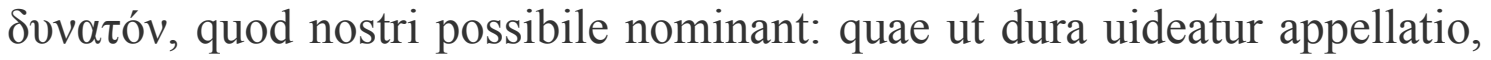
tamen sola est.

26. Quas partes non omnes in omnem cadere suasoriam manifestius est quam ut docendum sit. Tamen apud plerosque earum numerus augetur, a quibus ponuntur ut partes, quae superiorum species sunt partium. Nam fas, iustum, pium, aecum, mansuetum quoque (sic enim sunt interpretati iò

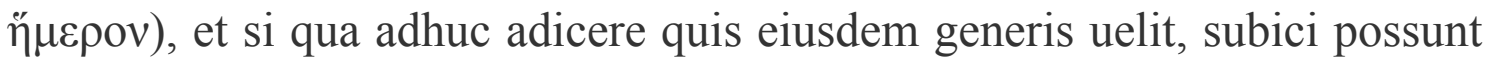
honestati.

27. An sit autem facile, magnum, iucndum, sine periculo, ad quaestionem pertinet utilitatis. Qui loci oriuntur ex contradictione: est quidem utile, sed difficile, paruum, iniucundum, periculosum. 28. Tamen quibusdam uidetur esse nonnumquam de iucunditate sola consultatio, ut si de aedificando theatro, instituendis ludis deliberetur. Sed neminem adeo solutum luxu puto, ut nihil in causa suadendi sequatur praeter uoluptatem. 29. Praecedat enim semper aliquid necesse est, ut in ludis honor deorum, in theatro non inutilis laborum remissio, deformis et incommoda turbae, si id non sit, 
conflictatio, et nihilo minus eadem illa religio, cum theatrum ueluti quoddam illius sacri templum uocabimus. 30. Saepe uero et utilitatem despiciendam esse dicimus, ut honesta faciamus (ut cum illis Opiterginis damus consilium ne se hostibus dedant, quamquam perituri sint, nisi fecerint), et utilia honestis praeferimus, ut cum suademus ut bello punico serui armentur. 31. Sed tamen neque hic plane concedendum est esse id inhonestum (liberos enim natura omnis et isdem constare elementis, et fortasse antiquis etiam nobilibus ortos dici potest), et illic, ubi manifestum periculum est, opponenda alia, ut crudelius etiam perituros adfirmemus, si se dediderint, siue hostis non seruarit fidem, siue Caesar uicerit, quod est uero similius. 32. Haec autem, quae tantum inter se pugnant, plerumque nominibus deflecti solent. Nam et utilitas ipsa expugnatur ab iis qui dicunt non solum potiora esse honesta quam utilia, sed ne utilia quidem esse, quae non sint honesta, et contra, quod nos honestum, illi uanum, ambitiosum, stolidum, uerbis quam re probabilius uocant.

33. Nec tantum inutilibus comparantur utilia, sed inter se quoque ipsa, ut si ex duobus eligamus, in altero, quid sit magis, in altero, quid sit minus. Crescit hoc adhuc; nam interim triplices etiam suasoriae incidunt, ut cum Pompeius deliberabat Parthos an Africam an Aegyptum peteret. Ita non tantum utrum melius, sed quid sit optimum quaeritur, itemque contra. 34 - Nec umquam incidet in hoc genere materiae dubitatio rei quae undique secundum nos sit; nam ubi contradictioni locus non est, quae potest esse 
causa dubitandi? Ita fere omnis suasoria nihil est aliud quam comparatio, uidendumque quid consecuturi simus et per quid, ut aestimari possit plus in eo, quod petimus, sit commodi, an uero in eo, per quod petimus, incommodi. 35. Est utilitatis et in tempore quaestio: 'expedit, sed non nunc', et in loco: 'non hic', et in persona: 'non nobis', 'non contra hos', et in genere agendi: 'non sic', et in modo: 'non in tantum'.

Sed personam saepius decoris gratia intuemur: quae et in nobis et in iis, qui deliberant, spectanda est. 36. Itaque, quamuis exempla plurimum in consiliis possint, quia facillime ad consentiendum homines ducuntur experimentis, refert tamen, quorum auctoritas et quibus adhibeatur: diuersi sunt enim deliberantium animi, duplex condicio. 37. Nam consultant aut plures aut singuli, sed in utrisque differentia, quia et in pluribus multum interest senatus sit an populus, Romani an Fidenates, Graeci an barbari, et in singulis, Catoni petendos honores suadeamus an C. Mario, de ratione belli Scipio prior an Fabius deliberet. 38. Proinde intuenda sexus, dignitas, aetas; sed mores praecipue discrimen dabunt. Et honesta quidem honestis suadere facillimum est; si uero apud turpes recta optinere conabimur, ne uideamur exprobrare diuersam uitae sectam cauendum. 39. Et animus deliberantis non ipsa honesti natura, quam ille non respicit, permouendus, sed laude, uulgi opinione, et, si parum proficiet haec uanitas, secutura ex his utilitate, aliquanto uero magis obiciendo aliquos, si diuersa fecerint, metus. 40. Nam praeter id, quod his leuissimi cuiusque animus facillime 
terretur, nescio an etiam naturaliter apud plurimos plus ualeat malorum timor quam spes bonorum, sicut facilior eisdem turpium quam honestorum intellectus

est. 41. Aliquando bonis quoque suadentur parum decora, dantur parum bonis consilia, in quibus ipsorum qui consulunt spectatur utilitas.

Nec me fallit quae statim cogitatio subire possit legentem: 'Hoc ergo praecipis et hoc fas putas?' 42. Poterat me liberare Cicero, qui ita scribit ad Brutum, praepositis plurimis quae honeste suaderi Caesari possint: 'Simne bonus uir, si haec suadeam? Minime. Suasoris enim finis est utilitas eius cui quisque suadet. At recta sunt: quis negat? Sed non est semper rectis in suadendo locus.' Sed quia est altior quaestio nec tantum ad suasorias pertinet, destinatus est mihi hic locus duodecimo, qui summus futurus est, libro. 43. Nec ego quicquam fieri turpiter uelim. Verum interim haec uel ad scholarum exercitationes pertinere credantur: nam et iniquorum ratio noscenda est, ut melius aequa tueamur.

44. Interim si quis bono inhonesta suadebit, meminerit non suadere tamquam inhonesta, ut quidam declamatores Sextum Pompeium ad piraticam propter hoc ipsum, quod turpis et crudelis sit, inpellunt, sed dandus illis deformibus color —idque etiam apud malos; neque enim quisquam est tam malus ut uideri uelit. 45. Sic Catilina apud Sallustium loquitur, ut rem scelestissimam non malitia, sed indignatione uideatur 
audere; sic Atreus apud Varium'iam fero, inquit, infandissima, iam facere cogor'.

Quanto magis eis quibus cura famae fuit conseruandus est hic uelut ambitus. 46. Quare et, cum Ciceroni dabimus consilium ut Antonium roget, uel etiam ut Philippicas, ita uitam pollicente eo, exurat, non cupiditatem lucis adlegabimus (haec enim si ualet in animo eius, tacentibus quoque nobis ualet), sed ut se rei publicae seruet hortabimur. 47. Hac illi opus est occasione, ne eum talium precum pudeat. Et C. Caesari suadentes regnum adfirmabimus stare iam rem publicam nisi uno regente non posse. Nam qui de re nefaria deliberat, id solum quaerit, quo modo quam minimum peccare uideatur.

48. Multum refert etiam quae sit persona suadentis, quia, ante acta uita si inlustris fuit aut clarius genus aut aetas aut fortuna adfert expectationem, prouidendum est ne quae dicuntur ab eo, qui dicit, dissentiant. At his contraria summissiorem quendam modum postulant. Nam quae in aliis libertas est, in aliis licentia uocatur, et quibusdam sufficit auctoritas, quosdam ratio ipsa aegre tuetur.

49. Ideoque longe mihi difficillimae uidentur prosopopoeiae, in quibus ad relicum suasoriae laborem accedit etiam personae difficultas: namque idem illud aliter Caesar, aliter Cicero, aliter Cato suadere debebit. Vtilissima uero haec exercitatio, uel quod duplicis est operis, uel quod poetis quoque aut historiarum futuris scriptoribus plurimum confert; uerum et oratoribus 
necessaria. 50. Nam sunt multae a Graecis Latinisque compositae orationes, quibus alii uterentur, ad quorum condicionem uitamque aptanda quae dicebantur fuerunt. An eodem modo cogitauit aut eandem personam induit Cicero, cum scriberet Cn. Pompeio et cum T. Ampio ceterisue, ac non unius cuiusque eorum fortunam, dignitatem, res gestas intuitus omnium, quibus uocem dabat, etiam imaginem expressit, ut melius quidem, sed tamen ipsi dicere uiderentur?

51. Neque enim minus uitiosa est oratio, si ab homine, quam si a re, cui accommodari debuit, dissidet. Ideoque Lysias optime uidetur in iis, quae scribebat indoctis, seruasse ueritatis fidem.

Enimuero praecipue declamatoribus considerandum est quid cuique personae conueniat, qui paucissimas controuersias ita dicunt ut aduocati: plerumque filii, patres, diuites, senes, asperi, lenes, auari, denique superstitiosi, timidi, derisores fiunt, ut uix comoediarum actoribus plures habitus in pronuntiando concipiendi sint, quam his in dicendo. 52. Quae omnia possunt uideri prosopopoeiae, quam ego suasoriis subieci, quia nullo alio ab his quam persona distat. Quamquam haec aliquando etiam in controuersias ducitur, quae ex historiis compositae certis agentium nominibus continentur. 53. Neque ignoro plerumque exercitationis gratia poni et poeticas et historicas, ut Priami uerba apud Achillem aut Sullae dictaturam deponentis in contione. Sed haec in partem cedent trium generum in quae causas diuisimus. Nam et rogare, indicare, rationem 
reddere et alia, de quibus supra dictum est, uarie atque ut res tulit in materia iudiciali, deliberatiua, demonstratiua solemus. 54. Frequentissime uero in his utimur ficta personarum, quas ipsi substituimus, oratione, ut apud Ciceronem pro Caelio Clodiam et Caecus Appius et Clodius frater, ille in castigationem, hic in exhortationem uitiorum compositus, adloquitur.

55. Solent in scholis fingi materiae ad deliberandum similiores controuersiis et ex utroque genere commixtae, ut cum apud C. Caesarem consultatio de poena Theodoti ponitur; constat enim accusatione et defensione causa eius, quod est iudicialium proprium; permixta tamen est et utilitatis ratio: 56. an pro Caesare fuerit occidi Pompeium, an timendum a rege bellum, si Theodotus sit occisus, an id minime opportunum hoc tempore et periculosum et certe longum sit futurum. 57. Quaeritur et de honesto: deceatne Caesarem ultio Pompei, an sit uerendum ne peiorem faciat suarum partium causam, si Pompeium indignum morte fateatur. 58. Quod genus accidere etiam ueritati potest.

Non simplex autem circa suasorias error in plerisque declamatoribus fuit, qui dicendi genus in his diuersum atque in totum illi iudiciali contrarium esse existimauerunt. Nam et principia abrupta et concitatam semper orationem et in uerbis effusiorem, ut ipsi uocant, cultum adfectauerunt, et earum breuiores utique commentarios quam legalis materiae facere elaborarunt. 59. Ego porro ut prohoemio uideo non utique opus esse suasoriis, propter quas dixi supra causas, ita cur initio furioso sit 
exclamandum non intellego, cum proposita consultatione rogatus sententiam, si modo est sanus, non quiritet, sed quam maxime potest ciuili et humano ingressu mereri adsensum deliberantis uelit. 60. Cur autem torrens et utique aequaliter concitata sit in ea dicentis oratio, cum uel praecipue moderationem rationemque consilia desiderent? Neque ego negauerim saepius subsidere in controuersiis impetum dicendi prohoemio, narratione, argumentis; quae si detrahas, id fere supererit, quo suasoriae constant, uerum id quoque aequalius erit, non tumultuosius atque turbidius.

61. Verborum autem magnificentia non ualidius est adfectanda suasorias declamantibus, sed contingit magis. Nam et personae fere magnae fingentibus placent, regum, principum, senatus, populi, et res ampliores; ita, cum uerba rebus aptentur, ipso materiae nitore clarescunt. 62. Alia ueri consilii ratio est, ideoque Theophrastus quam maxime remotum ab omni adfectatione in deliberatiuo genere uoluit esse sermonem, secutus in hoc auctoritatem praeceptoris sui, quamquam dissentire ab eo non timide solet. 63. Namque Aristoteles idoneam maxime ad scribendum demonstratiuam proximamque $a b$ ea iudicialem putauit, uidelicet quoniam prior illa tota esset ostentationis, haec secunda egeret artis uel ad fallendum, si ita poposcisset utilitas, consilia fide prudentiaque constarent. 64. Quibus in demonstratiua consentio (nam et omnes alii scriptores idem tradiderunt), in iudiciis autem consiliisque secundum condicionem ipsius, quae tractabitur, rei accommodandam dicendi credo rationem. 65. Nam et Philippicas 
Demosthenis isdem quibus habitas in iudiciis orationes uideo eminere uirtutibus, et Ciceronis sententiae et contiones non minus clarum quam est in accusationibus ac defensionibus, eloquentiae lumen ostendunt. Dicit tamen idem de suasoria hoc modo: 'Tota autem oratio simplex et grauis et sententiis debet ornatior esse quam uerbis'. 66. Vsum exemplorum nulli materiae magis conuenire merito fere omnes consentiunt, cum plerumque uideantur respondere futura praeteritis habeaturque experimentum uelut quoddam rationis testimonium. 67. Breuitas quoque aut copia non genere materiae sed modo constat; nam ut in consiliis plerumque simplicior quaestio est, ita saepe in causis minor.

Quae omnia uera esse sciet, si quis non orationes modo, sed historias etiam (namque in his contiones atque sententiae plerumque suadendi ac dissuadendi funguntur officio) legere maluerit quam in commentariis rhetorum consenescere. 68. Inueniet enim nec in consiliis abrupta initia, et concitatius saepe in iudiciis dictum, et uerba aptata rebus in utroque genere, et breuiores aliquando causarum orationes quam sententiarum. 69. Ne illa quidem in iis uitia deprendet, quibus quidam declamatores laborant, quod et contra sentientibus inhumane conuiciantur et ita plerumque dicunt, tamquam ab iis, qui deliberat, utique dissentiat, ideoque obiurgantibus similiores sunt quam suadentibus. 70. Haec adulescentes sibi scripta sciant, ne aliter quam dicturi sunt exerceri uelint, et in desuescendis morentur. Ceterum, cum aduocari coeperint in consilia amicorum, dicere sententiam 
in senatu, suadere si quid consulet princeps, quod praeceptis fortasse non credant usu docebuntur.

[De partibus causarum iudicialium]

1. Nunc de iudiciali genere, quod est praecipue multiplex, sed officiis constat duobus, intentionis ac depulsionis. Cuius partes, ut plurimis auctoribus placuit, quinque sunt: prohoemium, narratio, probatio, refutatio, peroratio. His adiecerunt quidam partitionem, propositionem, excessum; quorum priores duae probationi succidunt. 2. Nam proponere quidem quae sis probaturus necesse est, sed et concludere; cur igitur, si illa pars causae est, non et haec sit? Partitio uero dispositionis est species; ipsa dispositio pars rhetorices et per omnis materias totumque earum corpus aequaliter fusa, sicut inuentio elocutio. 3. Ideoque eam non orationis totius partem unam esse credendum est, sed quaestionum etiam singularum. Quae est enim quaestio, in qua non promittere possit orator quid primo, quid secundo, quid tertio sit loco dicturus? Quod est proprium partitionis. Quam ergo ridiculum est quaestionem quidem speciem esse probationis, partitionem autem, quae sit species quaestionis, partem totius orationis uocari! 4. Egressio uero, uel, quod usitatius esse coepit, excessus, siue est extra causam, non potest esse pars causae, siue est in causa, adiutorium uel ornamentum partium est earum, ex quibus egreditur. Nam si quidquid in 
causa est, pars causae uocabitur, cur non argumentum, similitudo, locus communis, adfectus, exempla partes uocentur? 5. Tamen nec $i$ is adsentior qui detrahunt refutationem, tamquam probationi subiectam, ut Aristoteles. Haec enim est quae constituat, illa quae destruat. Hoc quoque idem aliquatenus nouat, quod prohoemio non narrationem subiungit, sed propositionem; uerum id facit, quia propositio ei genus, narratio species uidetur, et hac non semper, illa semper et ubique credit opus esse.

6. Verum ex his, quas constitui, partibus, non ut quidque primum dicendum, ita primum cogitandum est; sed ante omnia intueri oportet quod sit genus causae, quid in ea quaeratur, quae prosint, quae noceant, deinde quid confirmandum sit ac refellendum, tum quo modo narrandum. 7. Expositio enim probationum est praeparatio nec esse utilis potest, nisi prius constituerit quid debeat de probatione promittere. Postremo intuendum quem ad modum iudex sit conciliandus; neque enim nisi totis causae partibus diligenter inspectis scire possumus qualem nobis facere animum cognoscentis expediat, seuerum an mitem, concitatum an remissum, aduersum gratiae an obnoxium.

8. Neque ideo tamen eos probauerim qui scribendum quoque prohoemium nouissime putant. Nam ut conferri materiam omnem, et, quid quoque $<$ loco $>$ sit opus, constare debet, antequam dicere aut scribere ordiamur, ita incipiendum ab iis quae prima sunt. 9. Nam nec pingere quisquam aut fingere coepit a pedibus, nec denique ars ulla consummatur ibi, unde 
ordiendum est. Quid fiet alioqui, si spatium componendi orationem stilo non fuerit? Nonne nos haec inuersa consuetudo deceperit? Inspicienda igitur materia.est quo praecepimus ordine, scribenda quo dicimus.

$$
\mathrm{X}
$$

[De generibus scribendi]

1. Ceterum causa omnis, in qua pars altera agentis est, altera recusantis, aut unius rei controuersia constat aut plurium: haec simplex dicitur, illa coniuncta. Vna controuersia est per se furti, per se adulterii. Plures aut eiusdem generis, ut in pecuniis repetundis, aut diuersi, ut si quis sacrilegii et homicidii simul accusetur.

Quod nunc in publicis iudiciis non accidit, quoniam praetor certa lege sortitur, principum autem et senatus cognitionibus frequens est et populi fuit. Priuata quoque iudicia saepe unum iudicem habere multis et diuersis formulis solent. 2. Nec aliae species erunt, etiam si unus a duobus dumtaxat eandem rem atque ex eadem causa petet, aut duo ab uno, aut plures a pluribus; quod accidere in hereditariis litibus interim scimus, quia, quamuis in multis personis, causa tamen una est, nisi si condicio personarum quaestiones uariauerit.

3. Diuersum his tertium genus, quod dicitur comparatiuum. Cuius rei tractatus in parte causae frequens est, ut cum apud centumuiros post alia quaeritur et hoc, uter dignior hereditate sit. Rarum est autem ut in foro 
iudicia propter id solum constituantur, sicut diuinationes, quae fiunt de accusatore constituendo, et nonnumquam inter delatores, uter praemium meruerit. 4. Adiecerunt quidam numero mutuam accusationem, ( $\dot{\alpha} v \tau \imath \kappa \alpha \tau \eta \gamma o \rho i ́ \alpha$ uocatur), aliis uidelicet succidere hanc quoque comparatiuo generi existimantibus. Cui similis erit petitionum inuicem diuersarum:

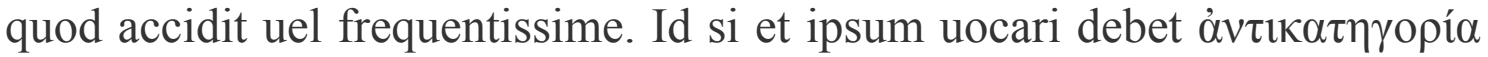
(nam proprio caret nomine), duo genera erunt eius: alterum quo litigatores idem crimen inuicem intentant, alterum, quo aliud atque aliud. Cui et petitionum condicio par est.

5. Cum apparuerit genus causae, tum intuebimur negeturne factum quod intenditur, an defendatur, an alio nomine appelletur, an a genere actionis repellatur: unde sunt status.

\author{
XI \\ [Quid sit quaestio, ratio, iudicatio, \\ continens et quatenus necessaria]
}

1. His inuentis intuendum deinceps Hermagorae uidetur quid sit quaestio, ratio, iudicatio, continens, uel, ut alii uocant, firmamentum.

Quaestio latius intellegitur omnis, de qua in utramque partem uel in plures dici credibiliter potest. 2. In iudiciali autem materia dupliciter accipienda est: altero modo, quo dicimus multas quaestiones habere controuersiam, 
quo etiam minores omnis complectimur, altero, quo significamus summam illam, in qua causa uertitur. De hac nunc loquor, ex qua nascitur status, an factum sit, quid factum sit, an recte factum sit. 3. Has Hermagoras et Apollodorus et alii plurimi scriptores proprie quaestiones uocant, Theodorus, ut dixi, capita generalia, sicut illas minores aut ex illis pendentes specialia; nam et quaestionem ex quaestione nasci et speciem in species diuidi conuenit. 4. Hanc igitur quaestionem ueluti principalem

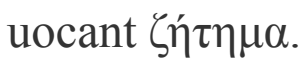

Ratio autem est qua id, quod factum esse constat, defenditur. Et cur non utamur eodem, quo sunt usi omnes fere exemplo? 'Orestes matrem occidit': hoc constat. Dicit se iuste fecisse. Status erit qualitatis; quaestio: 'An iuste fecerit'. Ratio, quod 'Clytaemestra maritum suum, patrem

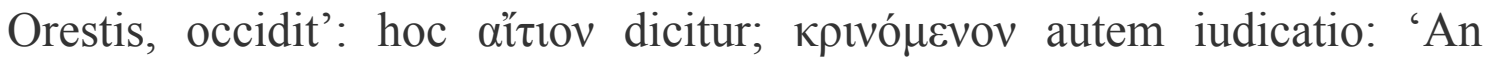
oportuerit uel nocentem matrem a filio occidi’

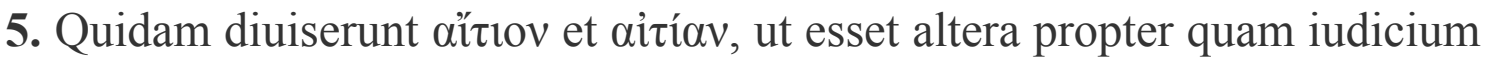
constitutum est, ut occisa Clytaemestra, altera qua factum defenditur, ut occisus Agamemnon. Sed tanta est circa uerba dissensio, ut alii aitíav causam iudicii, aîtıv autem facti uocent, alii eadem in contrarium uertant. Latinorum quidam haec initium et rationem uocauerunt, quidam utrumque

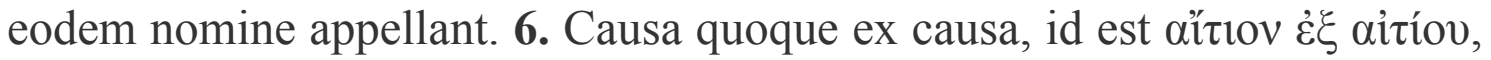
nasci uidetur, quale est: occidit Agamemnonem Clytaemestra, quia ille filiam communem immolauerat et captiuam paelicem adducebat. Idem 
putant et sub una quaestione esse plures rationes, ut si Orestes et alteram adferat causam matris necatae, quod responsis sit inpulsus. Quot autem causas faciendi, totidem iudicationes; nam et haec erit iudicatio, an responsis parere debuerit. 7. Sed et una causa plures habere quaestiones et iudicationes, ut ego arbitror, potest: ut in eo, qui, cum adulteram deprensam occidisset, adulterum, qui tum effugerat, postea in foro occidit; causa enim est una: 'adulter fuit'. Quaestiones et iudicationes, 'an illo tempore, an illo loco licuerit occidere'. 8. Sed sicut, cum sint plures quaestiones omnesque suos status habeant, causae tamen status unus est ad quem referuntur

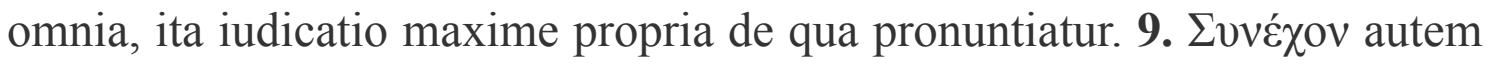
(quod, ut dixi, continens alii, firmamentum alii putant, Cicero firmissimam argumentationem defensoris et adpositissimam ad iudicationem) quibusdam id uidetur esse post quod nihil quaeritur, quibusdam, id quod ad iudicationem firmissimum adfertur. 10. Causa facti non in omnis controuersias cadit; nam quae fuerit causa faciendi, ubi factum negatur? At ubi causa tractetur, negant eodem loco esse iudicationem quo quaestionem, idque et in Rhetoricis Cicero et in Partitionibus dicit. 11. Nam in coniectura est quaestio ex illo: factum, non factum, an factum sit. Ibi ergo iudicatio, ubi quaestio, quia in eadem re prima quaestio et extrema disceptatio. At in qualitate: 'matrem Orestes occidit' 'recte' 'non recte', an recte occiderit quaestio, nec statim iudicatio. Quando ergo? 'Illa patrem meum occiderat.' 'Sed non ideo tu matrem debuisti occidere.' An debuerit: hic iudicatio. 12. 
Firmamentum autem uerbis ipsius ponam: 'Si uelit Orestes dicere eius modi animum matris suae fuisse in patrem suum, in se ipsum ac sorores, in regnum, in famam generis et familiae, ut ab ea poenas liberi potissimum sui petere debuerint.' 13. Vtuntur alii et talibus exemplis: 'Qui bona paterna consumpserit, ne contionetur'.- 'In opera publica consumpsit'. Quaestio: 'An quisquis consumpserit prohibendus sit'; iudicatio: 'An qui sic'. 14. Vel in causa militis Arrunti, qui Lusium tribunum uim sibi inferentem interfecit, quaestio: 'An iure fecerit'; ratio: quod is uim adferebat; iudicatio: an indemnatum, an tribunum a milite occidi oportuerit.

15. Alterius etiam status quaestionem, alterius iudicationem putant. Quaestio qualitatis, an recte Clodium Milo occiderit, iudicatio coniecturalis, an Clodius insidias fecerit. 16. Ponunt et illud, saepe causam in aliquam rem dimitti quae non sit propria quaestionis, et de ea iudicari. A quibus multum dissentio. Nam et illa quaestio an omnes, qui paterna bona consumpserint, contione sint prohibendi, habeat oportet suam iudicationem. Ergo non alia quaestio, alia iudicatio erit, sed plures quaestiones et plures iudicationes. 17. Quid? non in causa Milonis ipsa coniectura refertur ad qualitatem? Nam si est insidiatus Clodius, sequitur ut recte sit occisus. Cum uero in aliquam rem missa causa est, recessum est a quaestione quae erat, et hic constituta quaestio ubi iudicatio est.

18. Paulum in his secum etiam Cicero dissentit. Nam in rhetoricis, quem ad modum supra dixi, Hermagoran est secutus. In Topicis ex statu effectam 
contentionem крıvó $\mu \varepsilon v o v$ existimat, idque Trebatio, qui iuris erat consultus, adludens 'qua de re agitur' appellat; quibus id contineatur 'continentia', 'quasi firmamenta defensionis, quibus sublatis defensio nulla sit'. 19. At in Partitionibus Oratoriis 'firmamentum' quod opponitur defensioni, quia continens, quod primum sit, ab accusatore dicatur, ratio a reo, ex rationis et firmamenti quaestione disceptatio sit iudicationum.

Verius igitur et breuius, qui statum et continens et iudicationem esse uoluerunt: continens autem id esse, quo sublato lis esse non possit. 20. Hoc mihi uidentur utramque causam complexi, et quod Orestes matrem et quod Clytaemestra Agamemnonem occiderit. Idem iudicationem et statum consentire semper existimarunt; neque enim aliud eorum rationi conueniens fuisset.

21. Verum haec adfectata subtilitas circa nomina rerum ambitiose laborat, a nobis in hoc adsumpta solum, ne parum diligenter inquisisse de opere, quod adgressi sumus, uideremur. Simplicius autem instituenti non est necesse per tam minutas rerum particulas rationem docendi concidere. 22 . Quo uitio multi quidem laborarunt, praecipue tamen Hermagoras, uir alioqui subtilis et in plurimis admirandus, tantum diligentiae nimium sollicitae, ut ipsa eius reprehensio laude aliqua non indigna sit.

23. Haec autem breuior et uel ideo lucidior multo uia neque discentem per ambages fatigabit, nec corpus orationis in parua momenta diducendo consumet. Nam qui uiderit quid sit quod in controuersiam ueniat, quid in eo 
et per quae uelit efficere pars diuersa, quid nostra, quod in primis est intuendum, nihil eorum ignorare, de quibus supra diximus, poterit. 24. Neque est fere quisquam, modo non stultus atque ab omni prorsus usu dicendi remotus, quin sciat et quid litem faciat (quod ab illis causa uel continens dicitur), et quae sit inter litigantes quaestio, et de quo iudicari oporteat, quae omnia idem sunt. Nam et de eo quaestio est quod in controuersiam uenit, et de eo iudicatur de quo quaestio est. 25. Sed non perpetuo intendimus in haec animum et cupiditate laudis utcumque adquirendae uel dicendi uoluptate euagamur, quando uberior semper extra causam materia est, quia in controuersia pauca sunt, extra omnia, et hic dicitur de iis quae accepimus, illic de quibus uolumus. 26. Nec tam hoc praecipiendum est, ut quaestionem, continens, iudicationem inueniamus (nam id quidem facile est), quam ut intueamur semper, aut certe, si digressi fuerimus, saltem respiciamus, ne plausum adfectantibus arma excidant.

27. Theodori schola, ut dixi, omnia refert ad capita. His plura intelleguntur, uno modo summa quaestio item ut status, altero ceterae quae ad summam referuntur, tertio propositio cum adfirmatione, ut dicimus

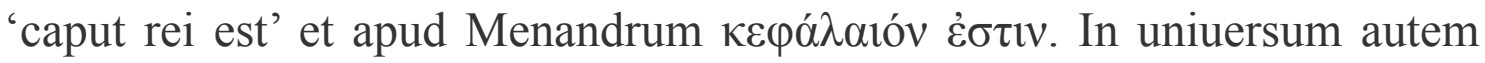
quidquid probandum est erit caput, sed id maius aut minus.

28. Et quoniam, quae de his erant a scriptoribus artium tradita, uerbosius etiam quam necesse erat, exposuimus, praeterea, quae partes essent 
iudicialium causarum supra dictum est, proximus liber a prima, id est exordio, incipiet. 


\section{BIBLIOGRAFIA}

\section{a) Do autor estudado}

QUINTILIAN. Institutio Oratoria. Trad. H. E. Butler. Cambridge: Harvard University Press, 1995-98.

- Institutio Oratoria. Trad. Donald A. Russell. London: Loeb Classical Library, 2002. 5 vols.

Institutio Oratoria. Book 2. Ed. Tobias Reinherdt \& Michael Winterbottom. Oxford: Oxford University Press, 2006.

QUINTILIANO. Instituição Oratória. Trad. Bruno Fregni Bassetto. Campinas: Editora da Unicamp, 2015.

Instituições Oratórias. Sel. e trad. Jerônimo Soares Barbosa. São Paulo: Edições Cultura, 1944. 2 vols.

La Formazione dell'Oratore. Vol. 1: Libri 1-4. Introd. Michael Winterbottom. Trad. Stefano Corsi. Milano: BUR, 1997.

—_— L'Istituzione Oratoria. A cura di Rino Faranda e Piero Pecchiura. Vol. I. Torino: UTET, 1979.

QUINTILIEN. L'Institution Oratoire. Texto e trad. Jean Cousin. Paris: Les Belles Lettres, 2003. 7 vols.

QUINTILIANO DE CALHORRA. Sobre la Formación del Orador. Trad. e comentários Alfonso Ortega Carmona. Salamanca: Publicaciones Universidad Pontificia, 1997-2001.

b) De autores antigos 
ARISTÓteleS. Poética. 5. ed. Trad. e introd. Eudoro de Sousa. Lisboa: Imprensa Nacional/Casa da Moeda, 1998.

Retórica. Introd. M. Alexandre Júnior. Trad. Manuel Alexandre Júnior, Paulo Farmhouse Alberto e Abel do Nascimento Pena. Lisboa: Imprensa Nacional/Casa da Moeda, 1998.

Obras Completas. Tópicos. Trad., introd. e notas J. A. Segurado e Campos. Lisboa: Imprensa Nacional, 2005.

- Categorias. Trad. José Veríssimo Teixeira da Mata. Goiânia: UFG/Alternativa, 2005.

. Tratados de Lógica. Introd., trad. y notas de Miguel Candel Sanmartín. Madrid: Gredos, 2007.

BERTACCHI, A. R. O Panegírico, de Isócrates. Tradução e comentário. Dissertação de mestrado, Departamento de Letras Clássicas e Vernáculas. FFLCH - USP, 2014.

CICERO. Academica. Trad. H. Rackham. Cambridge: Harvard University Press, 1994.

———. Brutus. Trad. G. L. Hendrickson. Cambridge: Harvard University Press, 1997.

De Inventione. Trad. H. M. Hubbell. Cambridge: Harvard University Press, 1993.

_-_-_. De Optimum Genere Oratorum. Trad. H. M. Hubbell. Cambridge: Harvard University Press, 1993.

- De Oratore. Books I-II. Trad. E. W. Sutton. Introd. H. Rackham. Cambridge: Harvard University Press, 1998.

. De Oratore. Book III. Trad. H. Rackham. Cambridge: Harvard University Press, 1997. 
. De Partitione Oratoria. Trad. H. Rackham. Cambridge: Harvard University Press, 1997.

-. "Do Orador 1.1-23". Trad. Adriano Scatolin. In: Translatio, n. 12, pp. 174-181. Porto Alegre, dez. 2016.

_____- "Do Orador 1.24-77". Trad. Adriano Scatolin. In: Translatio, n. 11, pp. 127-139. Porto Alegre, jun. 2016.

____- "Do Orador 1.78-122". Trad. Adriano Scatolin. In: Translatio, n. 10, pp. 80-89. Porto Alegre, dez. 2015.

" Do Orador 1.123-159". Trad. Adriano Scatolin. In: Nuntiuus Antiquus, v. 12, n. 2, pp. 264-287. Belo Horizonte, 2016.

Orator. Trad. H. M. Hubbell. Cambridge: Harvard University Press, 1997.

-. Topica. Trad. H. M. Hubbell. Cambridge: Harvard University Press, 1993.

-. Tratado da República. Trad., introd. e notas de Francisco de Oliveira. Lisboa: Círculo de Leitores, 2008.

——_- Tusculan Disputations. Trad. J. E. King. Cambridge: Harvard University Press, 1996.

———— Diálogos. Trad. Martinez Herranz, Gayo Arias, Aldo Berli. Los Clásicos. Madrid: E.D.A.F., 1967.

____ Acerca del Orador. Libros II-III. Introd., trad. e notas Amparo Gaos Schmidt. Ciudad de México: Universidad Nacional Autónoma de México, 1995.

DIÓGENES LAERCIO. Vida de los Filósofos Ilustres. Trad. Carlos García Gual. Madrid: Alianza, 2003. 
HERMOGENES DE TARSO. Invention and Method: two rhetorical treatises from the Hermogenic Corpus. Texto e ed. Hugo Rabe. Trad. e introd. George Kennedy. Atlanta: Atlanta Society of Biblical Literature, 2005.

ISOCRATE. Discours. 7. ed. Tomes I e II. Trad. G. Mathieu e E. Bremond. Paris: Les Belles Lettres, 2003/2008.

LUCRÉCIO. Da Natureza. Trad. e notas de Agostinho da Silva. São Paulo: Abril, 1973.

PLATÃO. Diálogos I. Trad. Edson Bini. São Paulo: Edipro, 2007.

Fedro. Introd., trad. e notas José Ribeiro Ferreira. Lisboa: Ed. 70, 2009.

____. Parménide, Théétète, le Sophiste. Paris: Gallimard, 1992.

PLINIO. Historia Natural. 3. vols. Trad. Guy Serbat, Antonio Fontán, Ana Maria Moure Casas. Madrid: Gredos, 1995.

Letters and Panegyricus. Trad. Betty Radice. Cambridge: Harvard University Press, 1989.

PLINIO EL JOVEN. Cartas. Introd., trad. y notas de Julián González Fernández. Madrid: Gredos, 2009.

PLUTARCO. Vidas paralelas. Solón - Publícola; Temístocles - Camilo; Péricles Fábio Máximo. Madrid: Gredos, 1996.

PLUTARQUE. Vie des Hommes Illustres. Trad. Alexis Pierron. Paris: Charpentier, 2016.

SENECA. Tragédias. Introd., trad. y notas de Germán Viveros. Ciudad de México: Universidad Nacional Autónoma de México, 1998.

SOFOCLES. Tragédias. Trad. José S. Lasso de la Vega y Assela Alamillo. Madrid: Gredos, 1990. 
SUETONiO. La Vida de los Doze Césares. Texto e trad. de Mariano Bassols Climent. Madrid: Consejo Superior de Investigaciones Científicas, 1999.

TACITE. Oeuvres Completes. Trad. et notes Pierre Grimal. Paris: Gallimard, 1990.

[ANAXÍMENES DE LÁMPSACO]. Retórica a Alejandro. Introd., trad. e notas de Juan Luis López Cruces, Javier Campos Daroca y Miguel Ángel Márquez Guerrero. Madrid: Gredos, 2005.

[CÍCERO]. Retórica a Herênio. Trad. e introd. Ana Paula Celestino Faria e Adriana Seabra. São Paulo: Hedra, 2005.

[CICERO]. Ad C. Herennium. Trad. Harry Caplan. Cambridge: Harvard University Press, 1989.

\section{c) Geral}

ALBALADEJO, T. "A estrutura comunicativa do discurso de gênero deliberativo na Institutio Oratoria de Quintiliano". In: Euphrosyne. Nova Série, n. 20, pp. 209-220. Universidade de Lisboa, 2002.

____ “_ The Three Types of Speechs in Quintilian, Book III. Comunicative Aspects of the Political and Legal Features of Rhetorical Discourse". In: TELLEGEN-COUPERUS, O. Quintilian and the Law. The Art of Persuasion in Law and Politics, pp. 51-58. Leuven: Leuven University Press, 2003.

ANDERSON JR., R. D. Glossary of Greek Rhetorical Terms. Leuven: V. Peeters, 2000 .

BACKES, J. G. “Aristotle's Theory of Stasis in Forensic and Deliberative Speech in the Rhetoric". In: Central States Speech Journal, n. 12, pp. 6-8. Taylor and Francis, 1960. 
BARCHIESI, A.; LA PENA, A.; MAZZOLI, G.; NARDUCCI, E. La Prosa Latina. Roma: La Nuova Italia Scientifica, 1991.

BONNER, S. F. Education in Ancient Rome. From the elder Cato to the younger Pliny. Berkeley: University of California Press, 1997.

___ _ "Roman Declamation in the Late Republic and Early Empire". In: Hemathema, n. 76, pp. 110-114. Trinity College Dublin, 1950.

-_- Roman Declamation in the Late Republic and Early Empire. Liverpool, University Press of Liverpool, 1949.

BLOOMER, W. M. The School of Rome: Latin Studies and the Origins of Liberal Education. Berkeley: University of California Press, 2011.

(Ed.) A Companion to Ancient Education. Hoboken: Wiley Blackwell, 2015.

BRAET, A. “Aristotle's Almost Unnoticed Contribution the Doctrine of Stasis”. In: Mnemosyne, vol. 52, 1999, pp. 408-433.

BRUNSCHWIG, J. "Rhétorique et dialectique, Rhétorique et Topiques". In: Furley-Nehamas, 1994, pp. 57-96.

BUCHHEIT, V. Untersuchung zur Theorie des Genos epideiktikon von Gorgias bis Aristoteles. München, 1960.

CAlboli MONTEFUSco, L. La Dottrina degli 'Status' nella Retorica Greca e Romana. Hildesheim: Georg Holms AG, 1986.

Exordium Narratio Epilogus. Bologna: C.L.E.B., 1988.

CAVARZERE, A. Oratoria a Roma. Roma: Carocci, 2000.

CHIRON, P. "Les Arts rhétoriques gréco-latins: strutures et fonctions". In Dossier Teknai/artes. Éditions de l'École des hautes études en sciences sociales. Éditons EHESS, 2007, p. 101-134. 
CLARK, D. L. "Imitation, theory and practice in Roman Rhetoric". In: Quaterly Journal of Speech, n. 37, 1951, pp. 11-22.

—__- Rhetoric in Greco-Roman Education. New York: Columbia University Press, 1957.

CLARKE, M. L. (1951). "The Thesis in the Roman Rhetorical Schools of the Republic”. In: Classical Quaterly, vol. 1, 1951, pp. 159-166.

—__ Higher Education in the Ancient World. London: Routledge \& Kegan Paul PLC, 1971.

Rhetoric at Rome: a historical survey. London: Routledge, 1996.

COUSIN, J. Études sur Quintilien. Contribution à la recherché des sources de l'Institution oratoire. Paris: Bouvin, 1936.

DEBORDES, F. La Rhétorique Antique: l'art de persuader. Paris: Hachette, 1996.

FALCON, A. (Ed.). Brill's Companion to the Reception of Aristotle in Antiquity. Leiden: Brill, 2016.

FERNANDEZ GARRIDO, R. Hermogenes de Tarso, sobre los Estados de la Causa. Logroño: Instituto de Estudios Riojanos, 2010.

FERNANDEZ LÓPEZ, J. "Dos notas sobre Quintiliano: genera causarum vs. genera rhetorices (Inst. 3,3-4) y decorum estilístico vs. decorum moral (Inst. 11-1)". In: Revista de Estudios Latinos, vol. 8. Madrid: Universidad Complutense - Sociedad de Estudios Latinos, 2008.

____ _Q "Quintilian as Rhetorician and Teacher". In: A Companion to Roman Rhetoric. Ed. William Dominik and Jon Hall. Malden: WileyBlackwell, 2010, pp. 307-322. 
FORTENBAUGH, W. "Cicero as a Reporter of Aristotelian and Theophrastean Rhetorica Doctrine". In: Rhetorica, vol. 23, n. 1, 2005, pp. 37-64.

; Steinmetz, P. (Ed.). Cicero's Knowledge of Peripatos. London: Transaction Publishers, 1989.

-—— - MIRHADY, D. C. (Ed.). Peripatetic Rhetoric after Aristotle. New Jersey: Transaction, 1994.

FUHRMANN, M. Untersuchung zur Textegechichte der pseudoaristotelischen Alexander-Rhetorik. Wiesbaden, 1965.

-__- Anaximenes Ars rhetoricae quae vulgo fertur Aristotelis Ad Alexandrum. Leipzig, 1966.

GERINI, G. B. (1859). Le Dottrine Pedagogiche di M. Tulio Cicerone, Anneo Seneca, M. Fabio Quintiliano e Plinio Il Giovane (facsímile). Charleston: Bibliobazaar, 2008.

GREER, W. J. "Quintilian and the Declamation". In: The Classical Weekly, vol. 19, n. 4, pp. 27-31. Classical Association of the Atlantic States, 1925.

GRIMAL, P. “Situation de Quintilien”. In: Vita Latina, n. 145, 1997, pp. 2-10.

GUNDERSON, E. (Ed.). The Cambridge Companion to Ancient Rhetoric. Cambridge: Cambridge University Press, 2009.

GÜNGERICH, R. "Der Dialogus des Tacitus und Quintilians Institutio Oratoria". In: Classical Philology, vol. 46, n. 3, pp. 159-164. The University of Chicago Press, 1951.

GWYNN, A. Roman Education from Cicero to Quintilian. Oxford: Teachers College Press, 1962. 
HEATH, M. "The Substructure of Stasis-Theory from Hermagoras to Hermogenes". In: Classical Quaterly. New Series, vol. 44, n. 1, pp. 114-129. Cambridge University Press, 1994.

“Hermagoras: Transmission and Attribution”. In: Philologus, vol. 146, 2002, pp. 287-298.

HESK, J. "Types of Oratory". In: GUNDERSON, E. (Ed.). The Cambridge Companion to Ancient Rhetoric, pp. 145-161. Cambridge: Cambridge University Press, 2009.

HINKS, D.A.G. “Tria Genera Causarum”. In: The Classical Quaterly, vol. 30, n. 3/4, pp. 170-176. Cambridge: Cambridge University Press, 1936.

HOLTSMARK, E. B. "Quintilian on status: a progymnasma”. In: Hermes, vol. 96, n. 3, pp. 356-368. Franz Steiner Verlag, 1968.

HUGONNARD-ROCHE, H. (Ed.). L'Enseignement Supérieur dans les Mondes Antiques et Mediévaux: Aspects Institutionels, Juridiques et Pédagogiques. Paris: Librairie Philosophique, 2009.

KENNEDY, G. “An Estimate of Quintilian". In: The American Journal of Philosophy, vol. 83, n. 2, pp. 130-146. The Johns Hopkins University Press, 1962.

-__ - The Art of Persuasion in Greece. New Jersey: Princeton University Press, 1963.

The Art of Rhetoric in the Roman World. New Jersey: Princeton University Press, 1972.

- A New History of Classical Rhetoric. New Jersey: Princeton University Press, 1994.

. Classical Rhetoric and its Christian and Secular Tradition from Ancient to Modern Times. 2. ed. Chapel Hill, London: The University of North Carolina Press, 1999. 
KRAUS, O. Über eine altübelieferte Mißdeutung der epideiktischen Redengattung bei Aristotle. Halle: Niemeyer, 1905.

___ Neue Studien zur aristotelischen Rhetorik, insbes. Über das

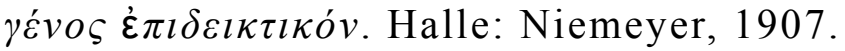

KROLL, W. “Rhetorik”. RE Suppl.7, Cols.1039-1038, 1940.

LAUSBERG, H. Handbook of Literary Rhetoric - A Foundation for Literary Study. Edited by David E. Orton \& R. Dean Anderson. Foreword by George A. Kennedy. Leiden: Brill, 1998.

LIU, Y. “Aristotle and the Stasis Theory". In: Rhetoric Society Quaterly, vol. 21, 1991, pp. 53-59.

Van MAL-MAEDER, D. La Fiction des Déclamations. Leiden: Brill, 2007.

MARROU, H-I. História da Educação na Antiguidade. São Paulo: EPU, 1975.

McEVOY, S. T. "Issues in Common Law Pleading and Ancient Rhetoric". In: Argumentation, vol. 5, pp. 245-261. Amsterdam: Kluwer Academic Publishers, 1991.

MIRHADY, D. C. "Aristotle, the Rhetorica ad Alexandrum and the tria genera causarum”. In: FORTENBAUCH, W. W.; MIRHADY, D. C. (Ed.). Peripatetic Rhetoric after Aristotle. New Jersey: Transaction Publishers, 1994, pp. 54-65.

MURPHY, J. J. (Ed.). Quintilian on the Teaching of Speaking and Writing. Carbondale-Edwardville: Southern Illinois University Press, 1987.

—__ _ "Le système des états de cause. L'Argumentation défensive". In: Poétique, n. 74, 1998, pp. 183-209.

NARDUCCI, E. Introduzione a Cicerone. Roma-Bari: Editori laterza, 1996. 
-__- "Eloquenza, Retorica, Filosofia nel De Oratore". In: CICERONE. Dell'Oratore. Con un saggio introdutivo di Emanuele Narducci. 4. ed. Milano: Biblioteca Universale Rizzoli, 1997.

NOCCHI, F. R. Tecniche Teatrali e Formazione dell'Oratore in Quintiliano. Berlin: Walter de Gruyter, 2013.

NATALI, C. “Ars e actus. Il fine dell'arte retorica secondo Quintiliano". In: Rhetorica, vol. 13, n. 2, pp. 161-178. University of California Press, 1995.

PATILlON, M. (Introd., trad. e notas). L’Art Rhétorique/Hermogène. Paris: Age d'homme, 1997.

—__- La Théorie du Discours chez Hermogène le Rhéteur: essai sur les structures linguistiques de la rhetórique ancienne. Paris: Les Belles Lettres, 1998.

___- (Ed.). Corpus Rhetoricum II. Hermogène: les états de cause. Paris: Les Belles Lettres, 2008.

PEREIRA, M. A. Quintiliano Gramático. São Paulo: Humanitas - FFLCH/ USP, 2006.

PEPE, C. The Genres of Rhetorical Speeches in Greek and Roman Antiquity. Leiden: Brill, 2013.

PERNOT, L. La Rhétorique de l'Éloge dans le Monde Grécque-romain. 2 vols. Paris: Institut d'Études Augustiniennes, 1993.

. La Rhétorique de l'Éloge dans le Monde Grécque-Romain. Tome I: Histoire et Technique. Paris: Institut d'Études Augustiniennes. 1993.

—__ La Rhétorique dans L’Antiquité. Paris: Librairie Générale Française, 2000.

—__ Epideitic Rhetoric. Questioning the Stakes of Ancient Praise. Austin: University of Texas Press, 2015. 
RAPP, C. Aristoteles, Rhetorik. Übersetzung und Kommentar, 2 vols. Berlin: Akademie Verlag, 2002.

RUBINELli, S. Ars Topica. The Classical Technique of Constructing Arguments from Aristotle to Cicero. Lugano: Springer, 2009.

RUSSELL, D. A. Greek Declamations. Harvard: Cambridge University Press, 1983.

SCATOlin, A. A Invenção no Do Orador de Cícero: um estudo à luz de Ad Familiares I, 9, 23. Tese de doutorado. DLCV - FFLCH/USP, São Paulo, 2009.

SPENGEL, L. V. Anaximenis Ars Rhetorica quae Vulgo Fertur Aristotelis ad Alexandrum. 2. ed. First published Zürich, 1844. Leipzig: Teubner, 1966.

SOLMSEN, F. "The Aristotelian Tradition in Ancient Rhetoric". In: The American Journal of Philosophy, vol. 62, n. 1, pp. 35-50. The Johns Hopkins University Press, 1941.

STEEL, C. "Divisions of Speech". In: GUNDERSON, E. (Ed.). The Cambridge Companion to Ancient Rhetoric, pp. 77-91. Cambridge: Cambridge University Press, 2009.

TOO, Y. L. (Ed.). Education in Greek and Roman Antiquity. Boston: Brill, 2001.

VAsconcelos, B. A. Ciência do Dizer Bem. A Concepção Retórica de Quintiliano em Institutio Oratoria II, 11, 21. São Paulo: Humanitas FFLCH/USP, 2005.

VIANO, C. "Quintiliano e la storia della filosofia: l'uso delle quaestiones philosopho convenientes". In: Rhetorica, vol. 13, n. 2, pp. 193-207. Berkeley: University of California Press, 1995. 
WALZER, A. E. "Quintilian's 'uir bonus' and the Stoic Wise Man”. In: Rhetorical Society Quaterly, vol. 33, n. 4, 2003, pp 25-41.

WARD, J. O. "Quintilian and the Rhetorical Revolution of the Middle Ages". In: A Journal of the History of Rhetoric, vol. 13, n. 3, pp. 231-284. Berkeley: University of California Press, 1995.

WINTERBOTTOM, M. "Quintilian and the uir bonus". In: The Journal of Roman Studies, vol. 54, parts 1 and 2, 1964, pp. 90-97.

WOERTHER, F. (Ed., trad. e coment.). Hermagoras. Fragments et Témoignages. Paris: Les Belles Lettres, 2012.

\section{d) Comentários}

ADAMIETZ, J. M. F. Quintiliani Institutionis Oratoriae Liber III. München: Wilhelm Fink Verlag, 1996.

TAYLOR JR., H. W. An Introduction and Commentary to Book 3 of Quintilian's Institutio Oratoria. Chapel Hill: University of North Carolina, 1971. 